\title{
WATER-RESOURCES APPRAISAL OF THE CAMP SWIFT LIGNITE AREA, CENTRAL TEXAS
}

By J. L. Gaylord, R. M. Slade, Jr., L. M. Ruiz,

C. T. Welborn, and E. T. Baker, Jr.

U.S. GEOLOGICAL SURVEY

Water-Resources Investigations Report 84-4333 
UNITED STATES DEPARTMENT OF THE INTERIOR

DONALD PAUL HODEL, Secretary

GEOLOGICAL SURVEY

Dallas L. Peck, Director

For additional information write to:

District Chief

U.S. Geological Survey

649 Federal Building

300 E. Eighth Street

Austin, TX 78701
Copies of this report can be purchased from:

Open-File Services Section Western Distribution Branch Box 25425, Federal Center Denver, C0 80225

Telephone: (303) 236-7476 


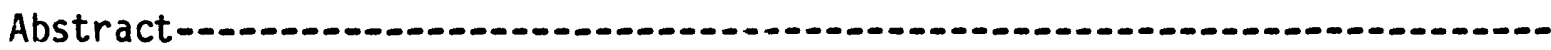

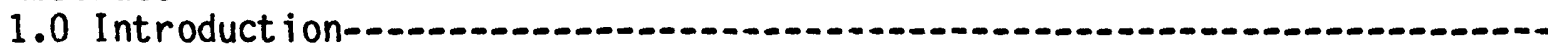

1.1 Objective-............................................................... 2

E. T. Baker, Jr.

1.2 Project area-1..-1.

J. L. Gaylord

1.3 Hydrologic problems related to surface mining-_...................... 6 J. L. Gaylord

2.0 General features

2.1 Stratigraphy

E. T. Baker, Jr.

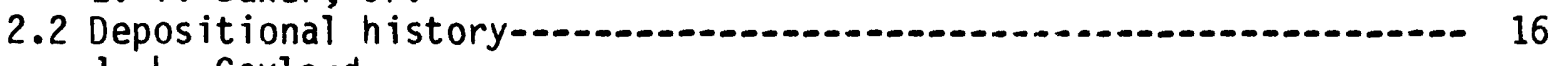

J. L. Gaylord

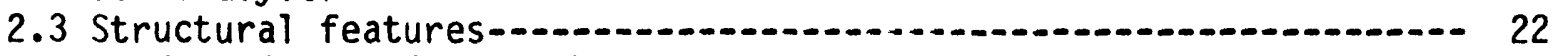

L. M. Ruiz and E. T. Baker, Jr.

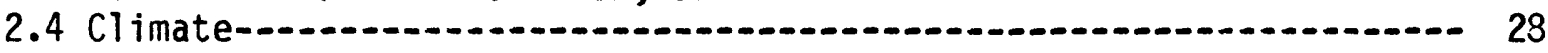

J. L. Gaylord

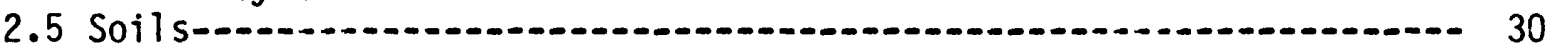

J. L. Gaylord

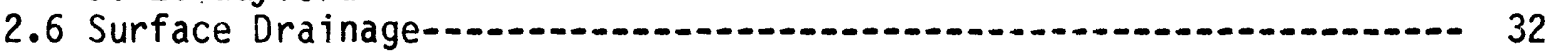

J. L. Gaylord and R. M. Slade, Jr.

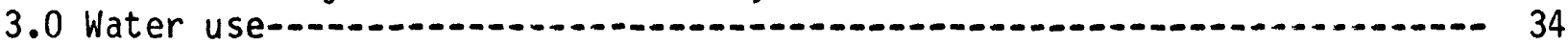

J. L. Gaylord

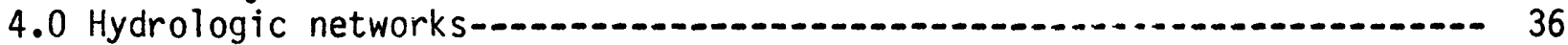

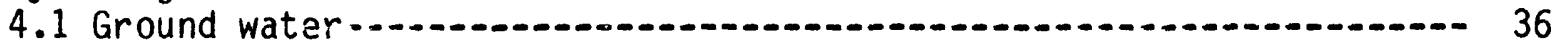

R. M. Slade, Jr. and E. T. Baker, Jr.

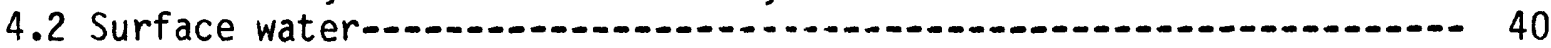

R. M. Slade, Jr.

5.0 Surface-water hydrology-.................................................. 44

6.0 Ground-water hydrology-................................................... 50

6.1 Source, recharge, and movement of ground water..................... 50

E. T. Baker, Jr.

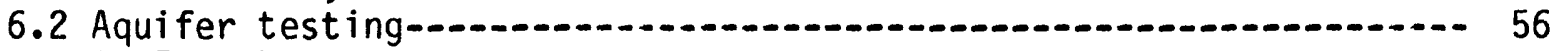

E. T. Baker, Jr.

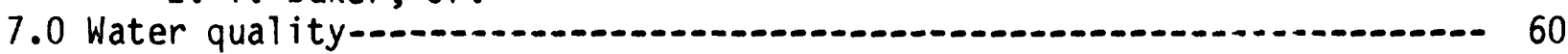

7.1 Surface-water quality-.............................................. 60

R. M. Slade, Jr.

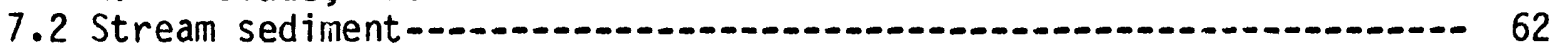

C. T. Welborn

Big Sandy Creek near McDade-_................................... 62

Big Sandy Creek near Elgin-........................................ 64

Dogwood Creek near McDade-....................................... 64

7.3 Ground-water quality-................................................. 66

R. M. Slade, Jr. and E. T. Baker, Jr. 


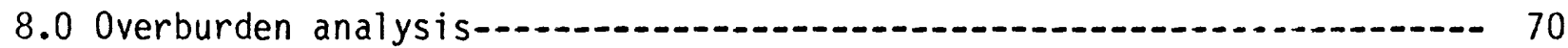

L. M. Ruiz and E. T. Baker, Jr.

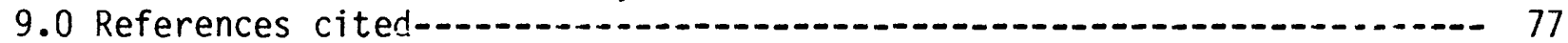

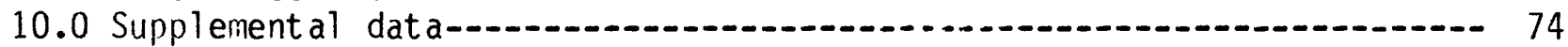

10.1 Records of test wells and test holes-............................. 74

10.2 Daily-mean discharge for gaging stations: Big Sandy Creek near McDade and Big Sandy Creek near Elgin-.................... 91

10.3 Water-quality and sediment analyses at streamflow sites..........- 99

10.4 Daily and monthly rainfall values for five recording rainfall gages, 1980 and 1981 water years-.................... 117

10.5 Incremental values of rainfall and runoff for selected

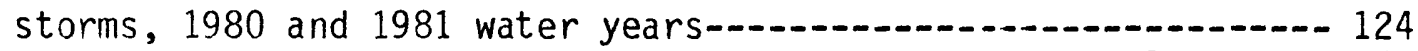

10.6 Summary of aquifer tests at the city of Bastrop well field-.-.--- 140

10.7 Source and significance of selected constituents and

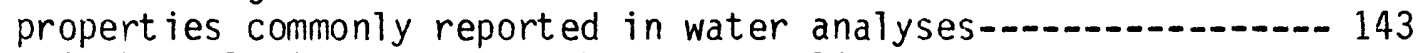

10.8 Chemical analysis of the overburden and lignite

from 0 to 255 feet at well C-13-............ 148

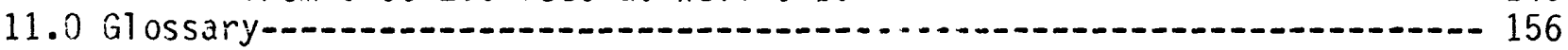

11.1 Geological- and ground-water-related terms-............................ 157

11.2 Surface-water and related terms-...................................-160 160

11.3 Water-qual ity-related terms-........................................ 162

11.4 Sediment-related terms-................................................ 164 
The inch-pound units of measurements used in this report may be converted to metric units by using the following conversion factors:

\section{Multiply}

inch

foot

mile

square mile

acre-foot

cubic foot per second

gallons per minute

million gallons per day

ton per day

million short tons

foot squared per day

foot per mile

foot per year

gallon per minute per foot

acre-foot per square mile per year
By

25.40

0.3048

1.609

2.590

1,233

0.001233

0.02832

0.06308

0.04381

0.9072

0.9072

0.09290

0.189

0.3048

0.2070

476.1
To obtain

millimeter

meter

kilometer

square kilometer

cubic meter

cubic hectometer

cubic meter per second

1 iter per second

cubic meter per second

megagram per day

teragram

meter squared per day

meter per kilometer

meter per year

liter per second per meter

cubic meter per square kilometer per year 


\author{
WATER-RESOURCES APPRAISAL OF THE \\ CAMP SWIFT LIGNITE AREA, CENTRAL TEXAS \\ By J. L. Gaylord, R. M. Slade, Jr., L. M. Ruiz, \\ C. T. Welborn, and E. T. Baker, Jr.

\section{ABSTRACT}

The Camp Swift lignite area was studied to describe the hydrogeology and to provide baseline data of the ground-water and surface-water resources that could be affected by the strip mining of lignite. The investigation was centered on the 18-square mile Camp Swift Military Reservation where a reported 80 to 100 million short tons of commercially mineable lignite occurs within 200 feet of the land surface.

Monthly ground-water levels from a network of 22 wells showed that water levels in wells in the Hooper, Simsboro, and Calvert Bluff Formations of the Wilcox Group had slight and generally insignificant waterlevel changes from May 1980 to May 1981. The water quality in the Calvert Bluff Formation, which contains the lignite, and in the Simsboro Formation, which is the major aquifer beneath the Calvert Bluff, generally is satisfactory for most uses. Hydraulic pressures in the Calvert Bluff are greater than in the Simsboro, and this pressure differential results in the potential for downward movenent of water from the Calvert Bluff to the Simsboro. However, confining beds of lignite, clay, silt, and other fine-grained material at and near the base of the Calvert
Bluff greatly retard this interformational movement of water but do not totally prevent downward leakage.

Data were collected from four streamflow stations and five automated rain gages to appraise the quantity and quality of the surface-water resources. Big Sandy Creek, which crosses Camp Swift, generally has a base flow of less than 0.5 cubic feet per second and infrequently is dry. Dogwood Creek, which uriginates on Camp Swift, normally is dry. The flow of both streams changes rapidly in response to rainfall in the watersheds. The quality of the water in both streams generally is suitable for most uses, but varies significantly in response to variations in discharge and related factors.

A lithologic examination of 255 feet of cored section that represents the overburden and the included $1 \mathrm{ig}$ nite showed cyclic layering of fine sand, silt, clay, and lignite. Chemical analyses of the core were performed to determine the contents of major inorganic and trace constituents. These analyses indicate that the content of pyritic sulfur generally is small but variable. 


\subsection{INTRODUCTION}

\subsection{Objective}

CAMP SWIFT REPORT SUBMITTED IN RESPONSE TO PROPOSED LIGNITE MINING

\section{The hydrologic and geologic conditions prior to mining are presented}

The objective of this report is to describe the hydrology and geology of an area of proposed lignite mining at Camp Swift and vicinity in central Texas (fig. 1.1-1), with emphasis on presenting baseline data of the ground-water and surface-water resources. The report provides general hydrologic information on individual water-resources topics (for example, ground-water quality) in a brief text with accompariying tables, maps, charts, graphs, or other illustrations. Such information should be usefu? to governmental and other ofo ficials, property owners in the area, and mine owrers and operators.

This report also is designed to heip meet the obijigations of the Federal Government to insure the compat. ibility of the development of the lignite reserves at Camp Swift with environmental regulations. Hydrologic assessments are required by the
"Surface Mining Control and Reclamation Act of 1977". Specifically, Public Law 95-81 requires: (1) That each mining permit applicant makes an analysis of the potential effects of the proposed mine on the hydrology of the mine site and adjacent area; (2) that "an appropriate Federal or State agency" provide to each miningpermit applicant "hydrologic information on the general area prior to mining"; and (3) that measures be taken by mining permittees to control adverse effects on the "hydrologic balance" and reclamation of the land.

Regulation of surface coal mining is being delegated to the States to insure environmental protection. On February 16, 1980, Texas became the first State to assume this responsibility. Enforcement in the State will be the responsibility of the Texas Railroad Commission. 


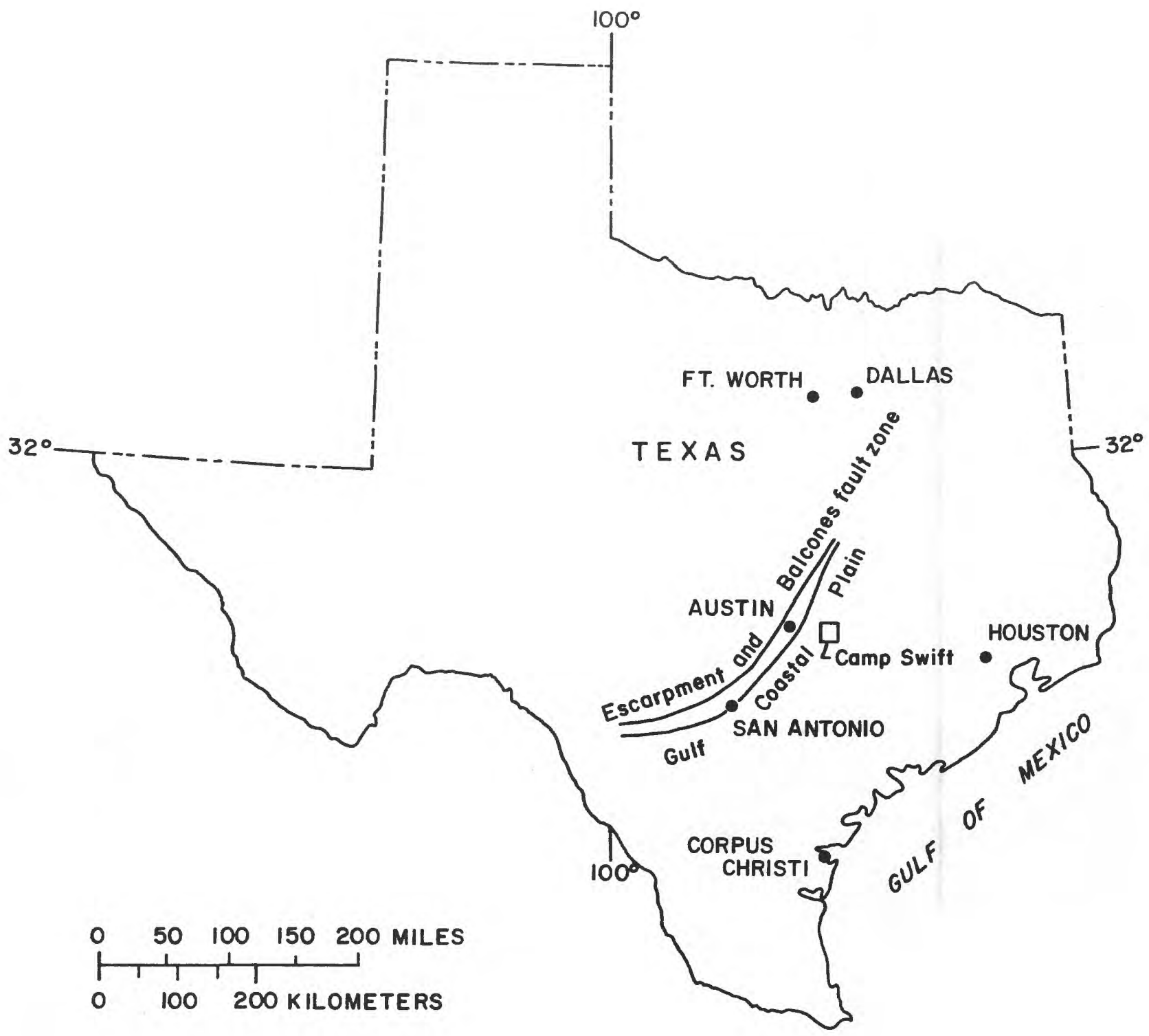

Figure 1.1-1.--Location of Camp Swift area. 


\subsection{INTRODUCTION--Continued}

\subsection{Project Area}

CAMP SWIFT, A MAJOR RESERVE OF FEDERALLY OWNED COAL, LOCATED IN COASTAL PLAIN NEAR URBAN AREAS

\section{Estimated lignite reserves of 80 to 100 million short tons underlying Camp Swift could be used for electric-power generation in Austin and San Antonio}

The Camp Swift area is located in Bastrop County, Texas, and is about $30 \mathrm{miles}$ east of Austin and 100 miles northeast of San Antonio (fig. 1.1-1). The area is entirely in the Coastal Plain Province. Surface features include a gentle rolling topography fairly densely covered with cedar, post oak, and pine trees (fig. 1.2-1).

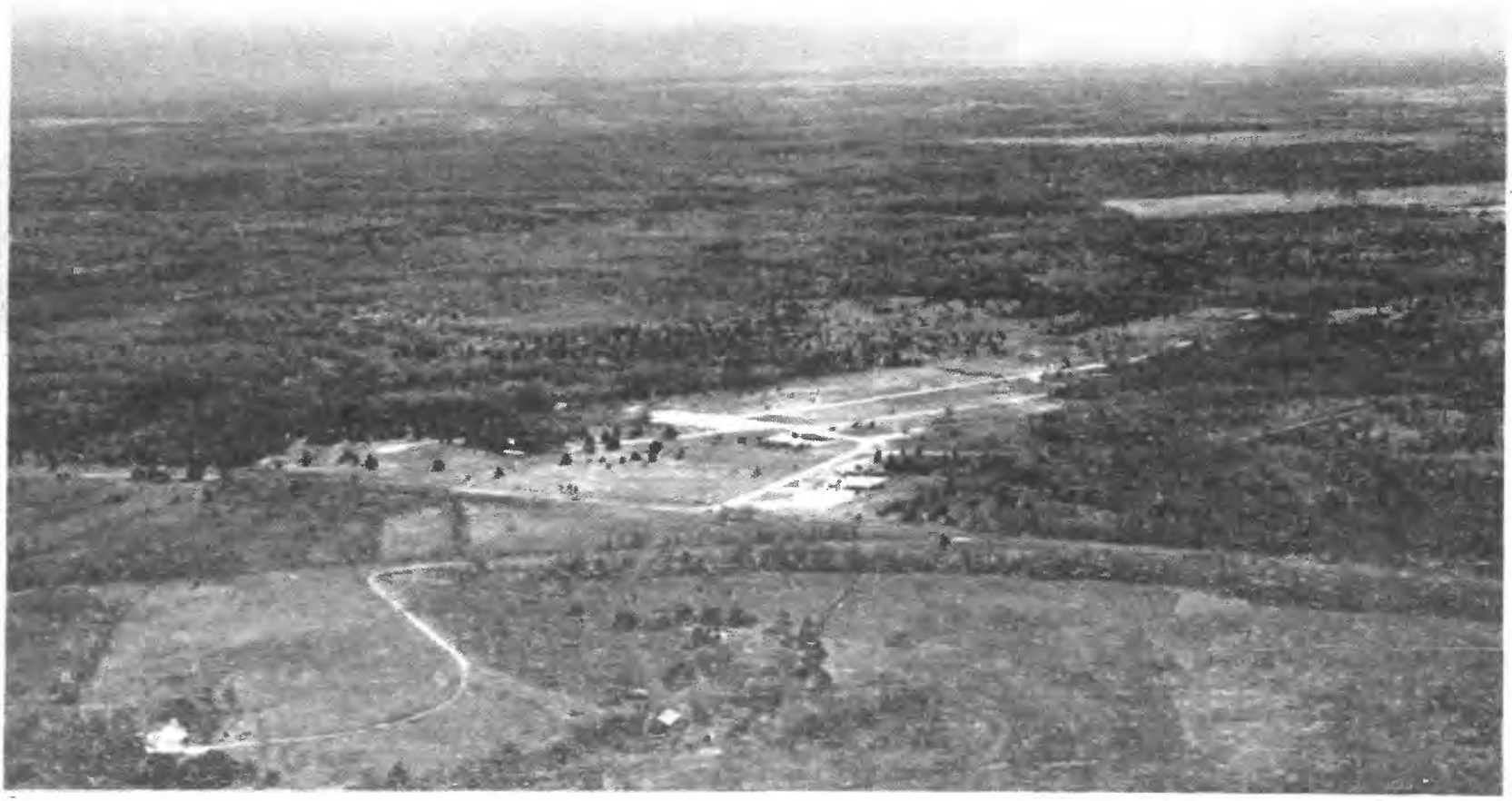

Figure 1.2-1--Areal view of Camp Swift. State Highway 95, which is seen crosing the lower half of the photograph, marks much of the western boundary of the area. Photograph courtesy of R. N. Mitchell Aerial Surveys, Austin, Texas, January 1983. 


\subsection{INTRODUCTION--Continued}

\subsection{Project Area--Continued}

The Camp Swift Military Reservation is leased from the U.S. Department of the Army by the Texas Army National Guard for military training exercises. This 18-square-mile area is one of the few tracts of Federal land in Texas underlain by commercially strippable lignite (figure 1.2-2). The auantity of lianite that underlies Camp Swift and that is economically recoverable. by surface-mining methods is estimated by the Lower Colorado River Authority of Austin, Texas, one of the lease applicants, to be from 80 to 100 million short tons (U.S. Bureau of Land Management, 1980). The proximity of the lignite to the Austin and San Antonio metropolitan areas makes it an attractive potential fuel source for a lignite-fired power-generating facility.

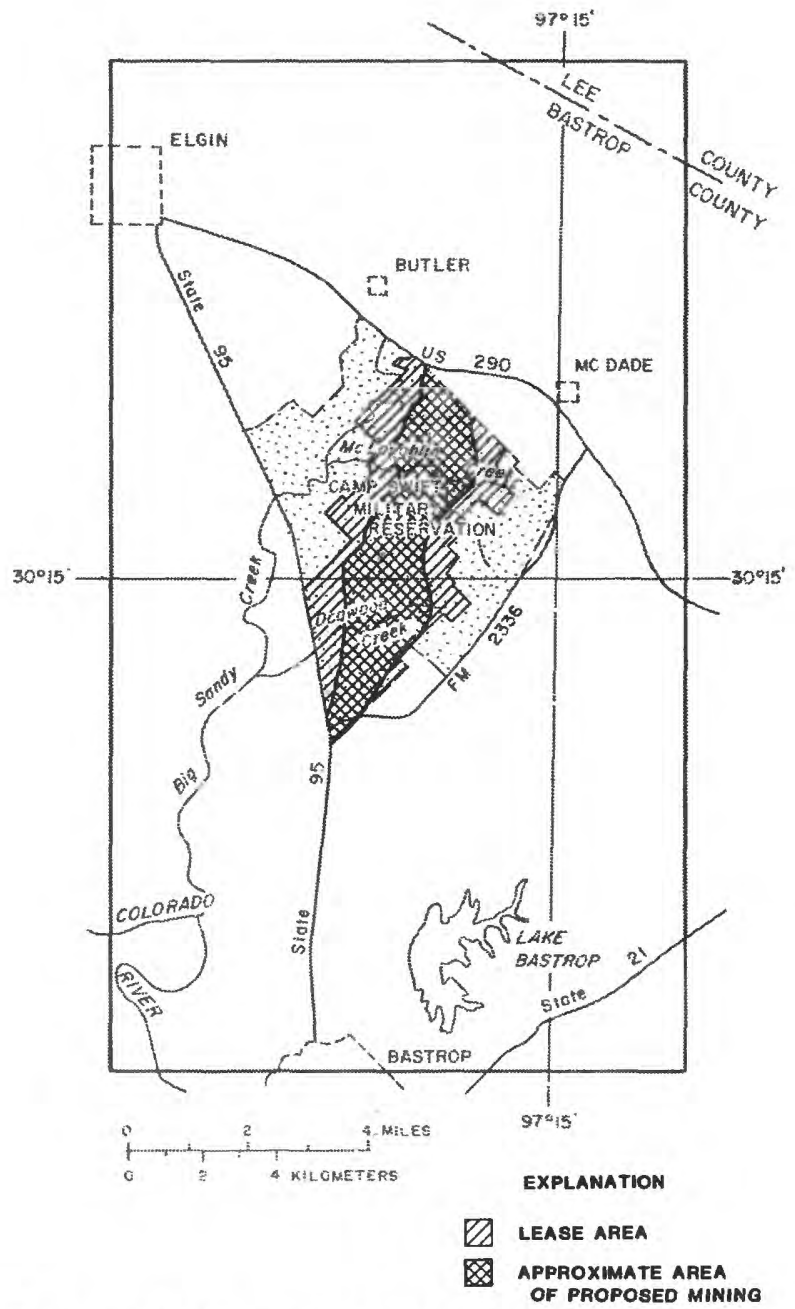

Figure 1.2-2.--Lease area and area of proposed mining. 


\subsection{INTRODUCTION--Continued}

\subsection{Hydrologic Problems Related to Surface Mining}

\section{HYDROLOGIC ENVIRONMENT MAY BE ADVERSELY AL TERED BY LIGNITE MINING}

$\frac{\text { Effects on water-bearing charcteristics of the reclaimed spoil, }}{\frac{\text { quantity and quality of ground water including water levels, }}{\text { quantity and quality of surface runoff, and increased }}}$

Strip mining drastically alters, at least temporarily, the environment of previously undisturbed lands. If a stripmined area remains unreclaimed, there might be long-term detrimental environmental consequences. The environmental concerns about strip mining in Texas are principally the effects of the mining operations on the water-bearing characteristics of the reclaimed spoil, effects on the spoil, quantity and quality of water in the mined and underlying aquifers including the declines in water levels in wells, changes in the quantity and quality of surface :unoff, and sediment yield from the stockpiled spoil and reclaimed areas.

The horizontal and vertical hydraulic conductivities for each strata of the undisturbed overburden commonly differ before mining. After mining, the overburden sediments are mixed, the original stratification is destroyed, and the hydraulic conductivities of the mixed material in the spoil probably are more homogeneous. A study by Mathewson (1979) on a reclaimed area of a lignite mine in Milam County, 30 miles northeast of Camp Swift, shows that the groundwater table had not recovered 8 years after the area was mined and reclamation began (fig. 1.3-1). Mathewson attributed this absence of a water table to a lack of adequate recharge vertically through the surface or horizontally through the materials that have minimal hydraulic conductivity. 


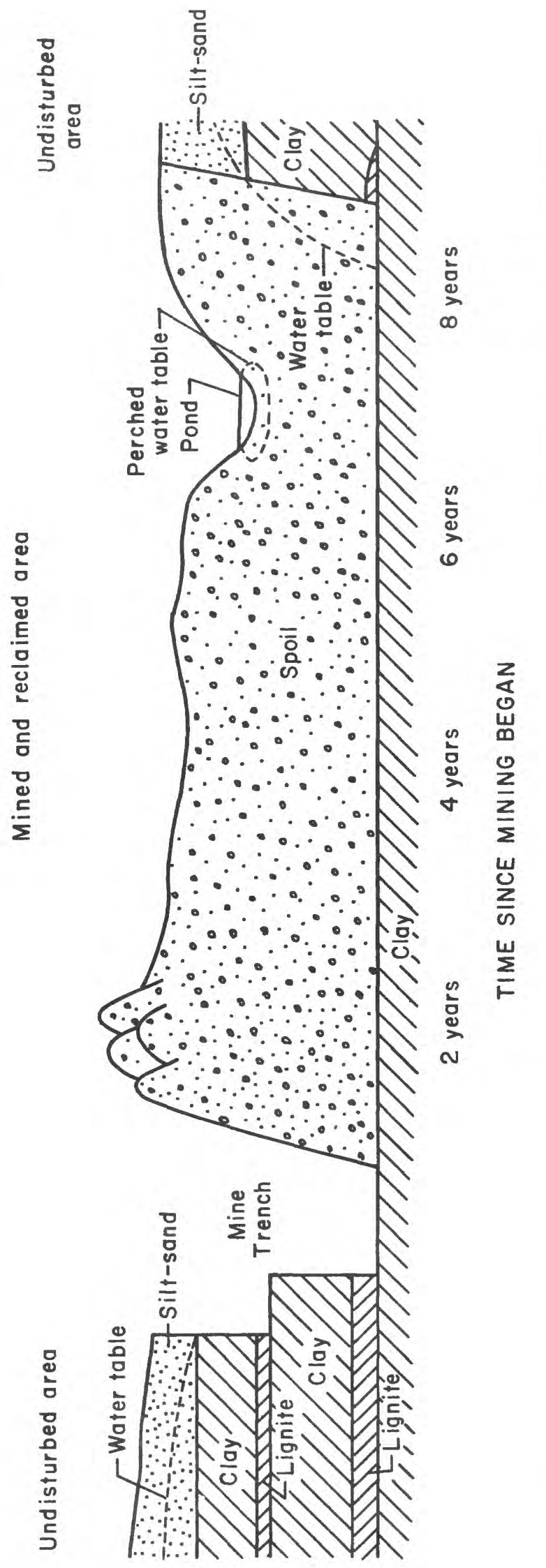

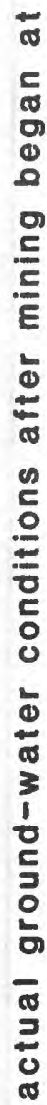

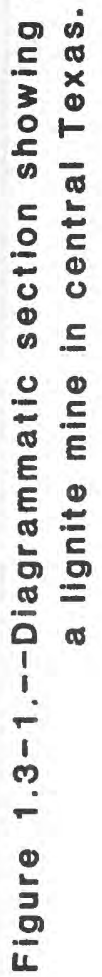




\subsection{INTRODUCTION--Continued}

\subsection{Hydrologic Problems Related to Surface Mining--Continued}

Strip mining in the Camp Swift a rea is expected to remove as much as 200 feet of overburden material. Dewatering or depressurizing probably will be necessary to maintain dry conditions during mining operations, and this will result in the decline in water levels in wells. Removal of the overburden will decrease the quantity of the shallow ground water, and possibly degrade its quality. Water of inferior quality could be introduced to the underlying aquifer after mining by leakage through the confining bed, as the potentiometric surface in the overlying aquifer above the confining bed is greater than the potentiometric surface in the underlying (major) aquifer (fig. 1.3-2). The hydraulic properties of the aquifer also could be adversely affected by the introduction of solutes from the surface-mining disturbance and from chemical precipitates that commonly form when waters of differing chemical composition intermix.

During mining, accelerated weathering of iron-bearing minerals (pyrite and marcasite) exposed in spoil materials and lignite beds may produce sulfuric acid and soluble mineral salts. Water draining such a mined area generally has $\mathrm{pH}$ values ranging from 2.5 to 5.0 , and larger sulfate, and dissolved-solids concentrations. The acidic water may react with other minerals and commonly increases concentrations of aluminum, copper, lead, iron, manganese, zinc, and other trace elements.

The areal effects of dewatering also might affect local streams. The waters probably will be released into Big Sandy Creek or its tributaries. Small creek channels commonly are diverted or obliterated during mining. The aquatic life of the larger receiving streams might be adversely affected by changes in quantity or quality of flow and by changes in sediment yields.

Careful planning before mining begins is necessary if the effects of these problems are to be prevented or minized before they occur. For example, the entrapment of mine waters in holding ponds could decrease sediment yields and allow for treatment of the water so as to decrease the harmful effects. During mining, continuous monitoring of the water resources in the area will be needed to indicate the extent of any changes in the quantity and quality of the water. 


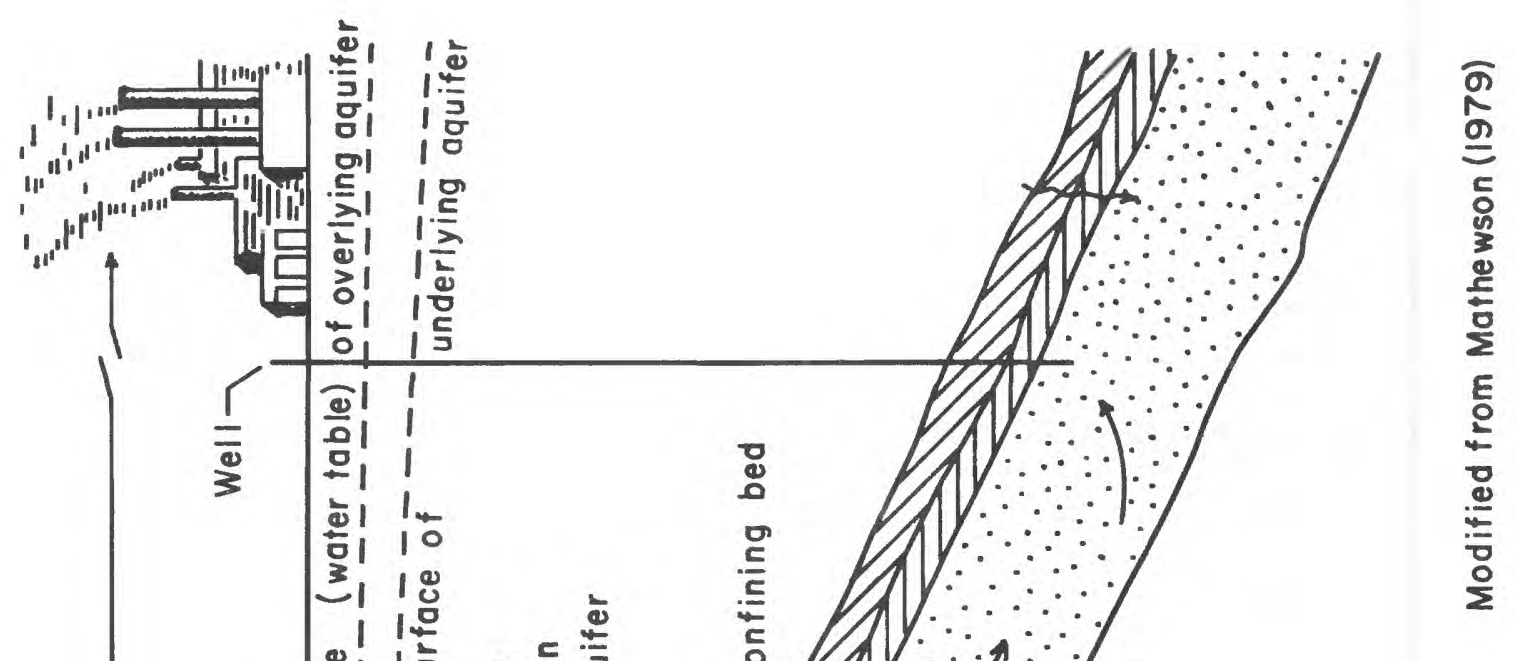




\subsection{GENERAL FEATURES}

\subsection{Stratigraphy}

\section{ENTIRE PROJECT AREA IS UNDERLAIN BY THE WILCOX GROUP}

The Wilcox Group is divided into three formations; from oldest to youngest, these are the Hooper, Simsboro, and Calvert Bluff Formations.

The stratigraphic nomenclature used in this report follows the usage of the Texas Bureau of Economic Geology as mapped on the Aust in sheet of the Geologic Atlas of Texas (Barnes, 1974) and does not follow the usage of the U.S. Geological Survey. The Wilcox Group of Eocene age, as used by the U.S. Geological Survey in east-central Texas, includes (ascending) the Seguin Formation, the Rockdale Formation (includes rocks assigned to the Hooper, Simsboro, and Calvert Bluff Formation), and the Sabinetown Formation. The definitions of selected geological terms are given in section 11.1.

The Wilcox Group of Eocene age, which is underlain by older rocks (clay) of the Midway Group and overlain by younger rocks (sand and clay) of the Claiborne Group, has been divided into three formations between approximately the Colorado River and Trinity River (Barnes, 1974). Upsection, these formations are the Hooper Formation, the Simsboro Forrnation, and the Calvert Bluff Formation. These formations are identified by an electric-loy shown in figure 2.1-1. 


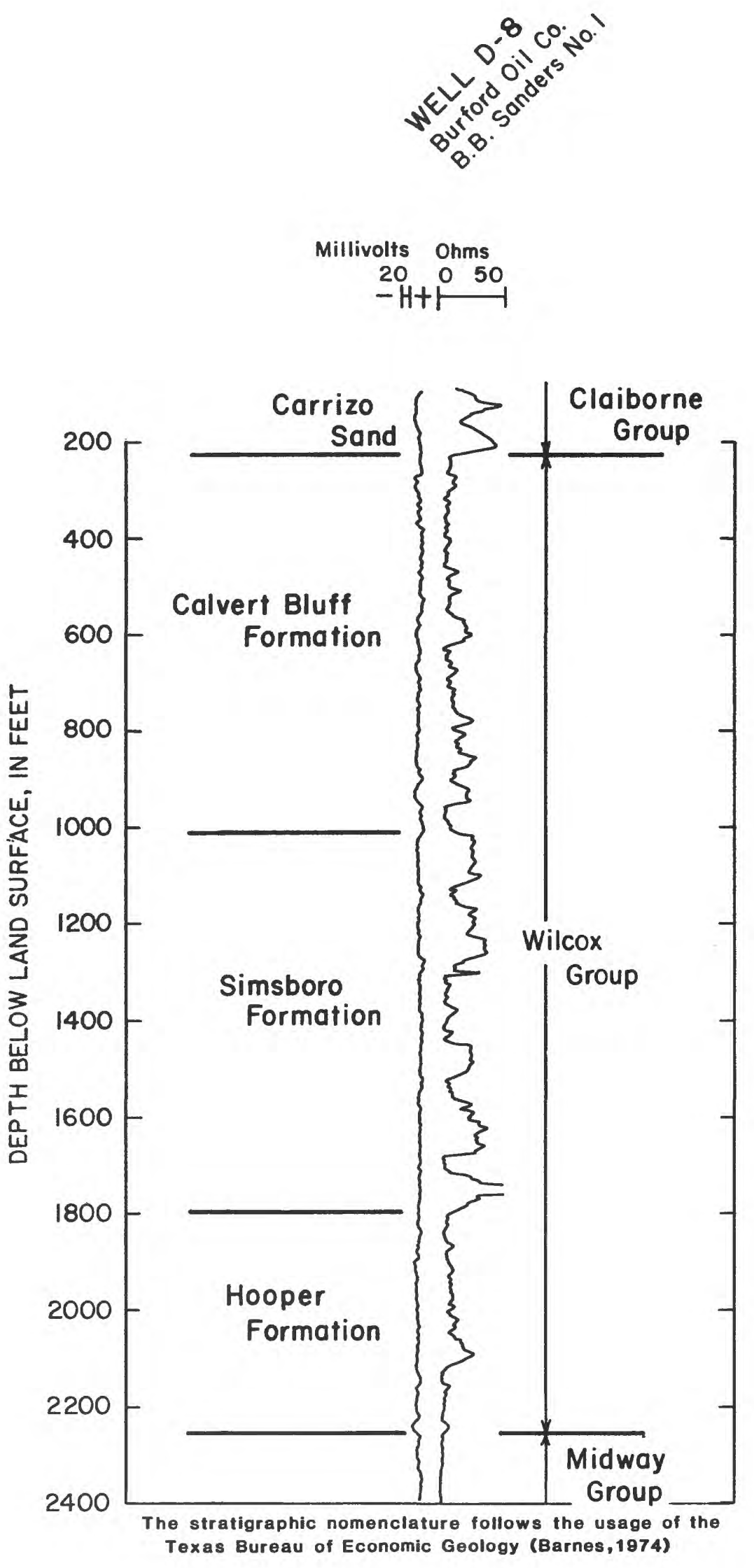

Figure 2.1-1.--Electric log of well D-8 penetrating the Wilcox Group. 


\subsection{GENERAL FEATURES--Cont inued}

\subsection{Stratigraphy--Continued}

All three formations crop out in northeast-trending bands in the study area; but according to Barnes (1974), only the Calvert Bluff crops out on the Camp Swift Military Reservation area (fig. 2.1-2).

The Hooper Formation is about 500-feet thick in the Camp Swift area and consists of mudstone, sand, sandstone, and a few beds of lignite. The mudstone is typically gray and weathers to a rusty-brown color. The sand and sandstone beds are light gray to $\tan$ and consist of very fine to medium grains. The sand usually is well sorted and subrounded. The lignite beds in the Hooper Formation at Camp Swift generally are dark brown, thin, discontinuous, and considered noncommercial to recover by surface mining.
The Simsboro Formation overlies the Hooper Formation and consists chiefly of fine to coarse unconsolidated sand, with thin discontinuous beds of mudstone and clay. The Simsboro commonly is light gray in fresh exposure but weathers to a rusty brown. The sand grains are moderate$1 y$ well sorted and subangular. Smallscale cross-bedding is common. LocalIy near its outcrop, the Simsboro is as much as 500 feet thick; however, the formation thickens downdip to more than 800 feet. A few miles southwest of the Colorado River, the Simsboro is undistinguishable from the Hooper and Calvert Bluff, and the three formations are mapped together as undivided Wilcox (Barnes, 1974). 

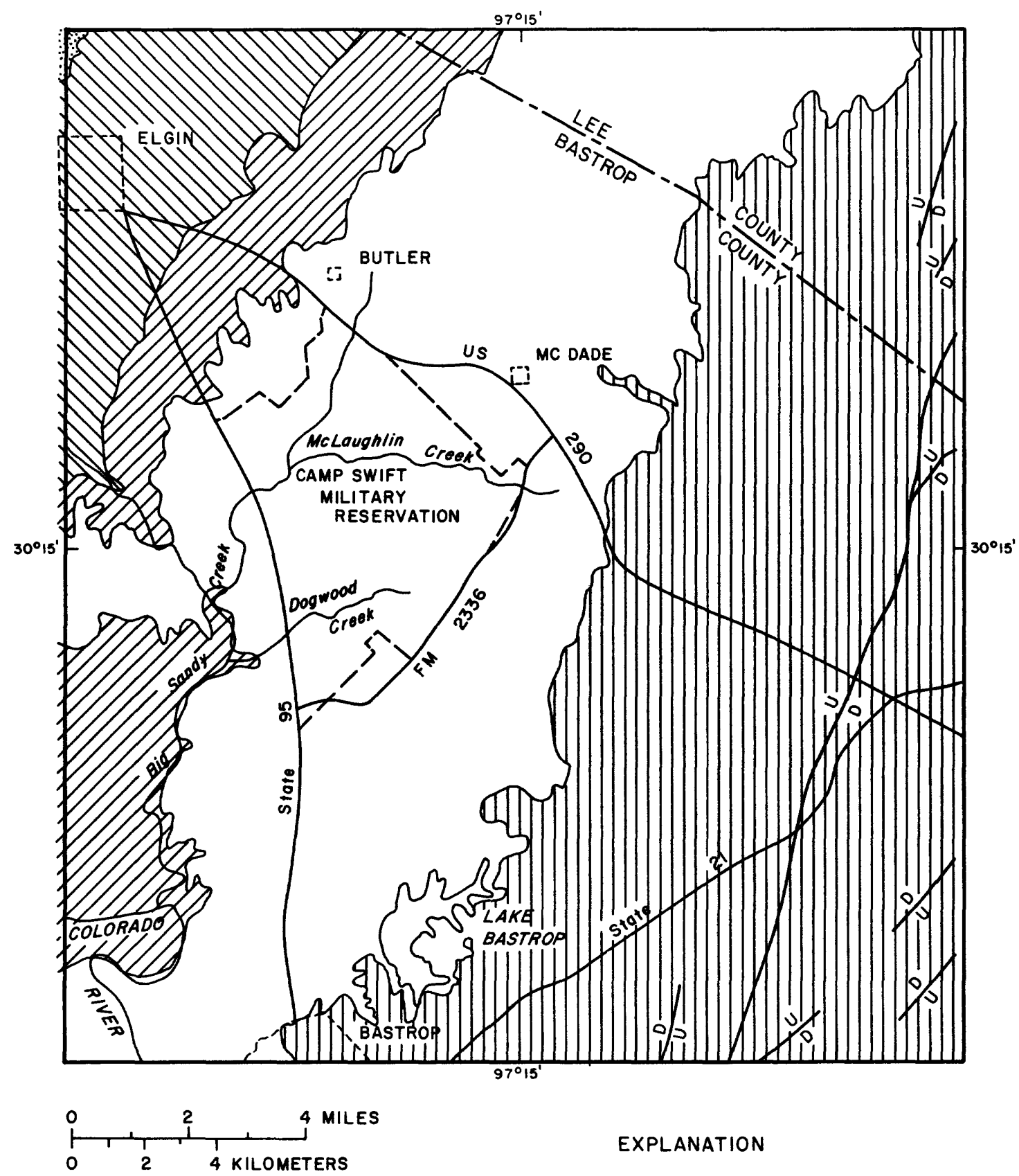

EXPLANATION

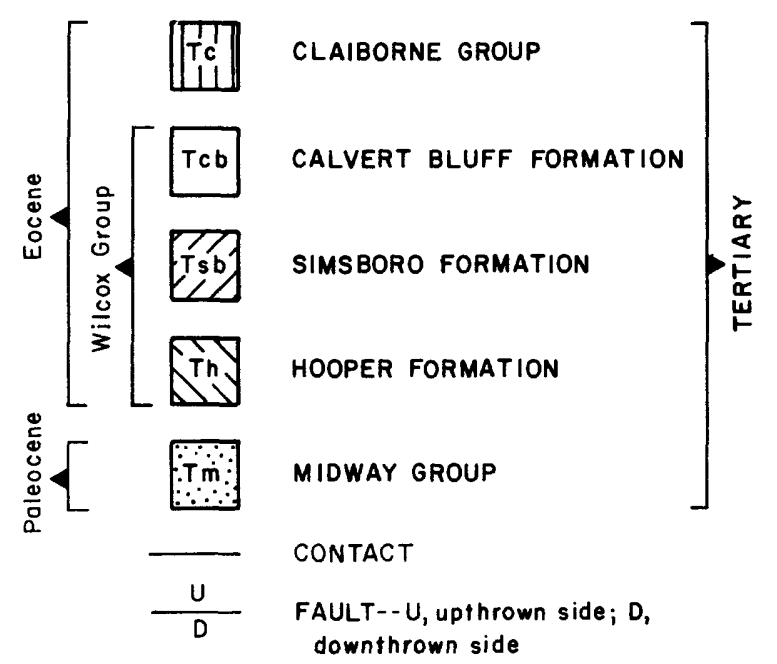

Figure 2.1-2.--Geologic map of the study area. 


\subsection{Stratigraphy--Continued}

The Calvert Bluff Formation overlies the Simsboro Formation and consists of beds of mudstone, sand, clay, sandstone, and lignite. The color of the mudstone varies from buff to light gray. The clay generally is dark gray and occurs in small lenses. The sand beds are tan to light gray with grain size ranging from very fine to coarse. The sand is well sorted and subrounded. Small-scale cross-bedding is very common in the sand beds. The sandstone is in the form of "hard streaks" commonly cemented by iron minerals. The lignite is typically dark brown to black and friable and has a locally "woody" texture where fossil imprints of the organic material are visible. Pyrite commonly is associated with the lignite as a secondary mineral deposited by ground water.

There are at least 11 separate lignite beds of varying thickness and quality in the Calvert Bluff Formation in the Camp Swift area. The thickness of these beds ranges from less than 1 to about 12 feet. The two or three lignite beds being considered for mining are in the lower part of the formation, about 10 to 70 feet above the top of the Simsboro Formation. The response of lignite on an electric log of a well drilled on Camp Swift is shown in figure 2.1-3. The $\log$ was run in the freshwater part of the Calvert Bluff with the borehole filled with freshwater drilling mud. Under these conditions, many of the lignite beds typically are indicated by a negative deflection of the spontaneous-potential curve and a highly resistive deflection of the resistivity curve. The thickness of the Calvert Bluff varies, but averages about 800 to 1,000 feet near the downdip edge of the outcrop. 


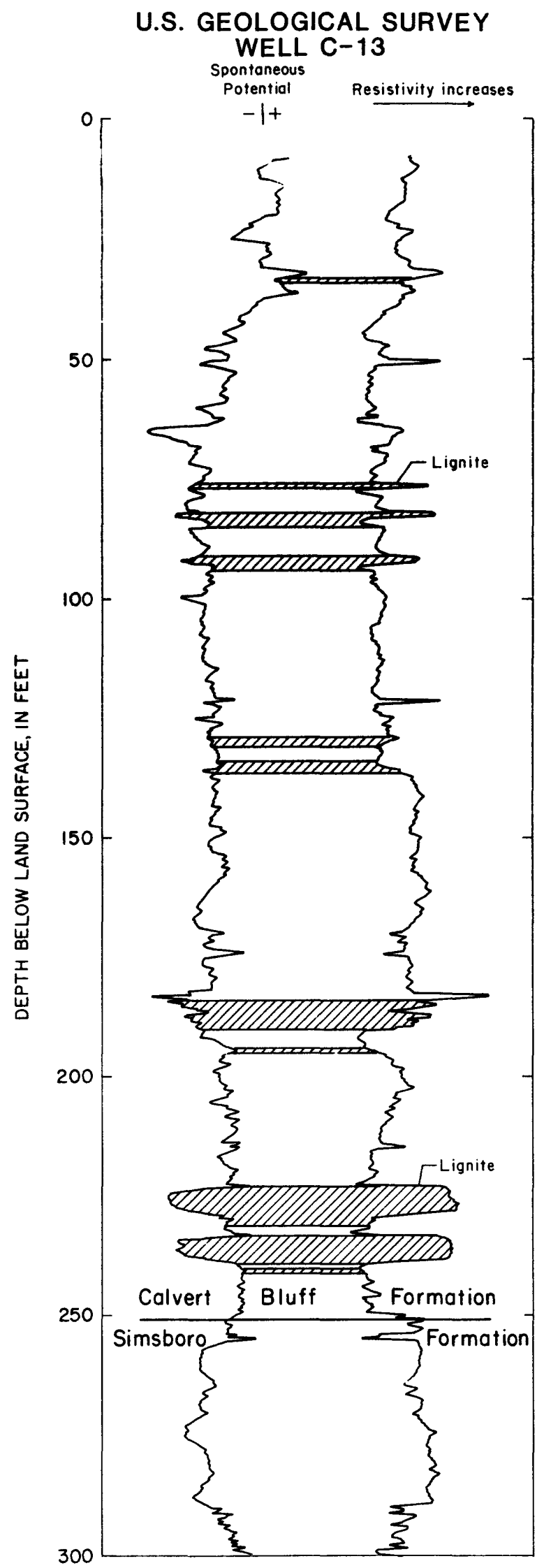

Figure 2.1-3.--The electrical response of lignite on an electric log of well $\mathrm{C}-13$. 


\subsection{Depositional History}

ENVIRONMENT OF DEPOSITION OF THE WILCOX GROUP IN THE CAMP SWIFT AREA WAS A FLUVIAL AND DELTAIC SYSTEM

Lignite formed in interchannel areas where paleo-swamps and marshes were filled with organic materials

The Hooper Formation was deposited as a series of delta front and interdistributary channel sequences. The definitions of selected geological terms are given in section 11.1. Coarsening-upward sequences of the prograding delta are visible on an electric $\log$ of the formation (fig. 2.2-1). The lignite beds in the Hooper are very thin, discontinuous, and not of immediate economic importance in this area (Fisher, 1963).
The Simsboro Formation was deposited in a fluvial environment after additional progradation of the delta system. The massive sands of the Simsboro were deposited from sediment-laden rivers that avulsed repeatedly, thus releasing their loads. This type of deposition was extensive in Bastrop County. On the Camp Swift Military Reservation total-sand accumulation in the Simsboro averages about 250 feet. 
WELL D-16

Amerado Petroleum Corporation

Mrs. Pauline Dolgener No.I

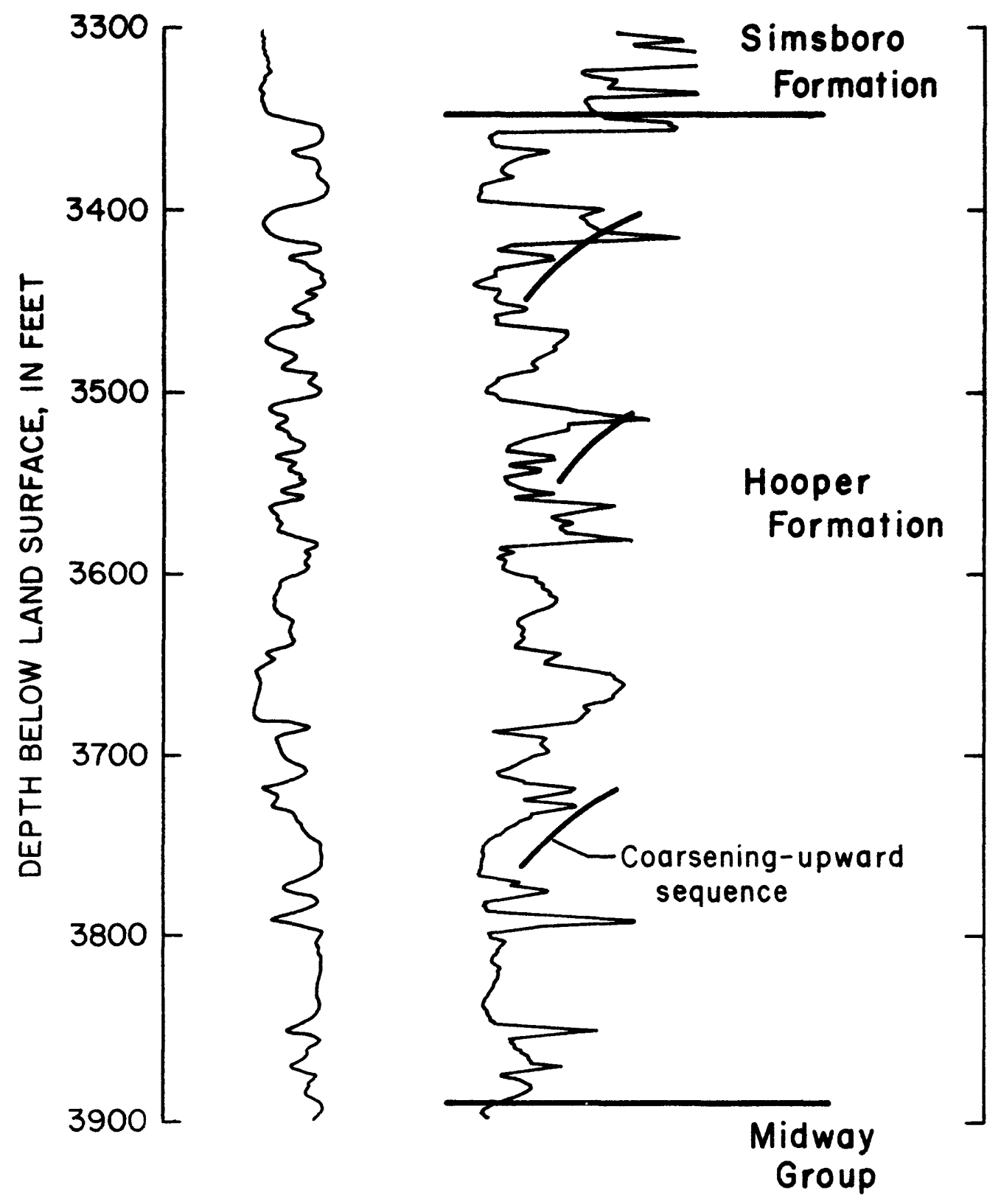

Figure 2.2-1.--Electric log of well D-16. 


\subsection{Depositional History--Continued}

A total-sand map of the Simsboro Formation in Bastrop County (Kaiser and others, 1980), which gives an indication of channel geometry is shown in figure 2.2-2. In Bastrop County, the channel geometry of the Simsboro is straight to slightly dendritic.
This type of geometry is common on modern fluvial and delta-front systems like that of the Mississippi River. Ancient channel geometry is important in terms of ground-water distribution and movement, which are discussed in section 6.1. 


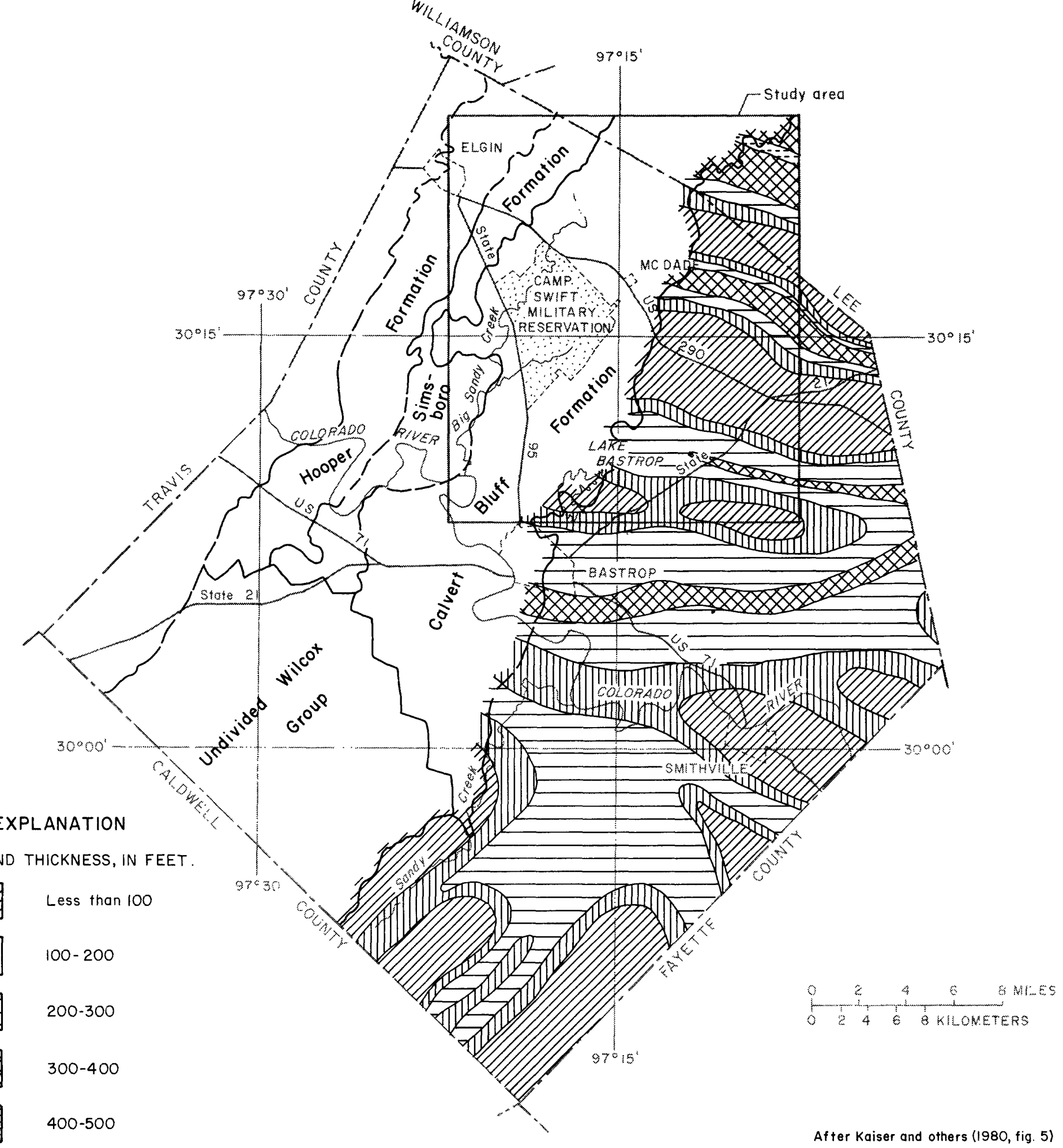

Figure 2.2-2.--Total-sand thickness of the Simsboro Formation in Bastrop and part of Lee Counties. 


\subsection{GENERAL FEATURES--Continued}

\subsection{Depositional History--Continued}

The Calvert Bluff Formation represents a transitional facies between a dendritic fluvial channel of the high alluvial plain and a bifurcating distributary channel facies of the lower delta plain (Kaiser and others, 1978). Large lignite occurrences correlate with the small-sandpercent areas, or interchannel areas, where organic material accumulated. Large-sand-percent areas represent ancient channels, which currently facilitate ground-water movement in the Calvert Bluff (fig. 2.2-3).

Fluvial and deltaic depositional systems commonly are complex sequences of transgressions and regressions of ancient seas. A common sequence of deposition is as follows (Bishop, 1977): (1) Avulsion occurs and a new channel course is established; (2) rapid subsidence of the avulsed channel commences creating interchannel lakes and swamps; (3) organic material accumulates until the rate of subsidence is greater than the rate of accumulation or until a major sediment influx occurs; (4) sediment influx is re-established with the advent of extensive overbank deposits; (5) the crevasse splays advance toward the lower part of the interchannel basin depositing upward-coarsening sequences; and (6) continued progradation and joining of crevasse splays and their abandonment repeat the cycle. In the Wilcox Group at Camp Swift, this sequence of events is preserved as a cyclic sequence of coarsening-upward interchannel basin cycles bounded by lignites. 


\subsection{GENERAL FEATURES--Continued}

\subsection{Structural Features}

THE REGIONAL DIP OF THE FORMATIONS IS AFFECTED BY FAULTING

The structure of the Camp Swift area is affected by northeasttrending normal faults that are downthrown to the northwest.

The Hooper, Simsboro, and Calvert Bluff Formations of the Wilcox Group dip regionally from 90 to 170 feet per mile and have an average dip of about 130 feet per mile. A regional dip section in the study area is shown in figure 2.3-1.

The structure of the Camp Swift area is affected by several northeasttrending normal faults, which are downthrown to the northwest. The net slip on the faults along their trend varies from one end of an individual fault to the other end. The series or zone of faults in the study area is 20 to 30 miles east of, and approximately parallel to, the Balcones fault zone, a major structural feature of central Texas. Between these two zones of faulting, the area is a structurally down-dropped block or graben. All of this faulting occurred in the Miocene Epoch from 27 to 12 million years ago. Considering the depositional framework controlling the distribution of Calvert Bluff sediments, lateral discontinuities of strata in some places within the study area are the result of this faulting. 

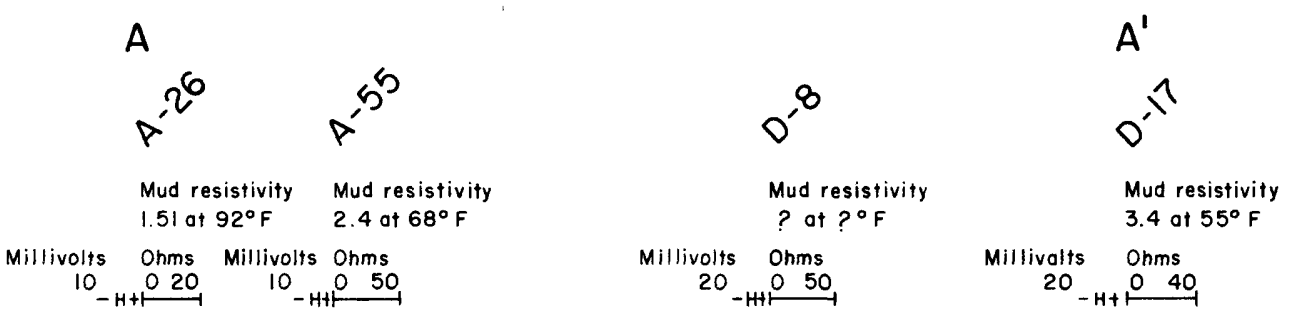

FEET

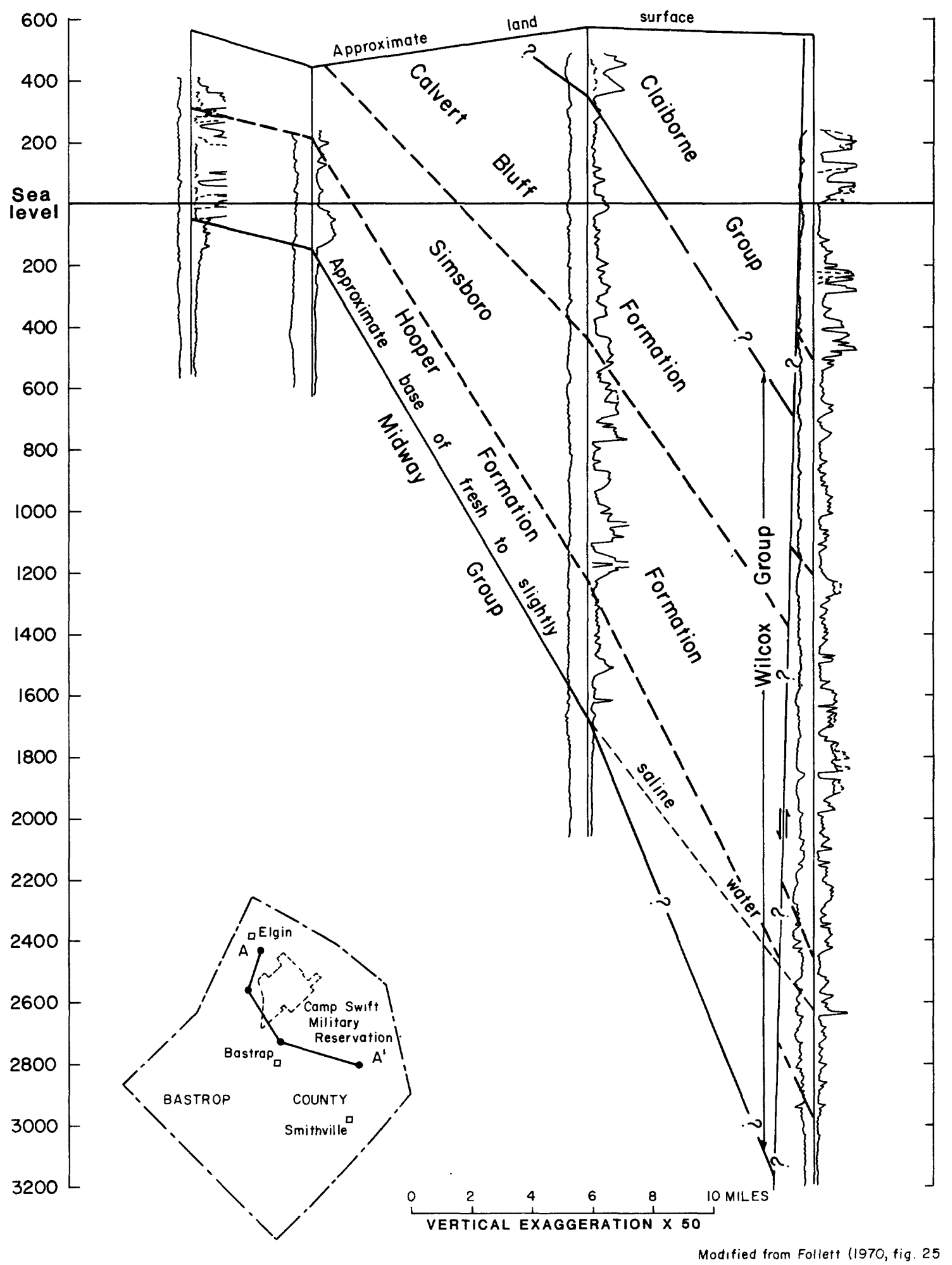

Figure 2.3-1.--Regional structural dip section $A-A^{\prime}$ in Bastrop County. 


\subsection{GENERAL FEATURES--Continued}

\subsection{Structural Features--Continued}

Faults have been identified and mapped during the present and previous geologic or hydrologic investigations. The locations of the faults that are in or near the Camp Swift Military Reservation are shown in figure 2.3-2. The faults are discussed briefly in the following paragraphs.

The U.S. Geological Survey in 1941 and 1942 (Guyton, 1942) conducted extensive pumping tests in the city of Bastrop well field (formerly the Camp Swift well field), 5 miles north of the city of Bastrop. Results of these tests indicated the nearby presence of a barrier to ground-water flow, which suggested a fault, between wells $\mathrm{C}-14$ and $\mathrm{C}-15$ in the well field. The throw of this fault which is termed the "wellfield fault", is not known, but it probably is the continuation of the Powell Bend fault, Elliott (1947b).

Elliott (1945, 1947a, and 1947b), described the oil potential of southwestern Bastrop County. Based on surface and subsurface studies, Elliott identified three faults within the study area. These faults trend north-northeast and are downthrown to the northwest. Two of the faults, the Powell Bend fault and the Bastrop fault, are oriented toward Camp Swift and may continue further to the northeast than the mapping indicates. The Sayersville fault, which is the most prominent of the three faults, crosses the northwestern part of
Camp Swift and has an estimated throw at this location of about 250 feet. Ten miles southwest of Camp Swift, its throw as reported by Elliott (1947a) is about 500 feet.

C. R. Follett (1970) noted that the formations in Bastrop County are transected by several faults or fault systems that trend northeastward across the county and generally are parallel to the strike of the formations. A fault identified by Follett (1970) in the area about 5 miles northeast of Elgin is termed the "Elgin-Rutler fault" (fig. 2.3.-2). Its exposure in a clay pit shows sand to be faulted opposite mostly clay. The fault's southerly trend is toward the Camp Swift Military Reservation where it probably joins the Sayersvi?le Fault.

In 1980, the Geological Survey drilled three closely-spaced test holes (50 feet apart) on Camp Swift for geologic and hydrologic purposes. A fault having a throw of 15 to 25 feet was indicated by differences in depths to key lignite beds in the test holes. The downthrown side is on the southeast. This fault is termed the "Survey fault" in figure 2.3-2. It is considered to be either one of a series of parallel faults or possibly an auxiliary or branch fault that may end diagonally against the Sayersville fault to the west and against a possible continuation of the Well-Field and Powell Bend faults to the south. 


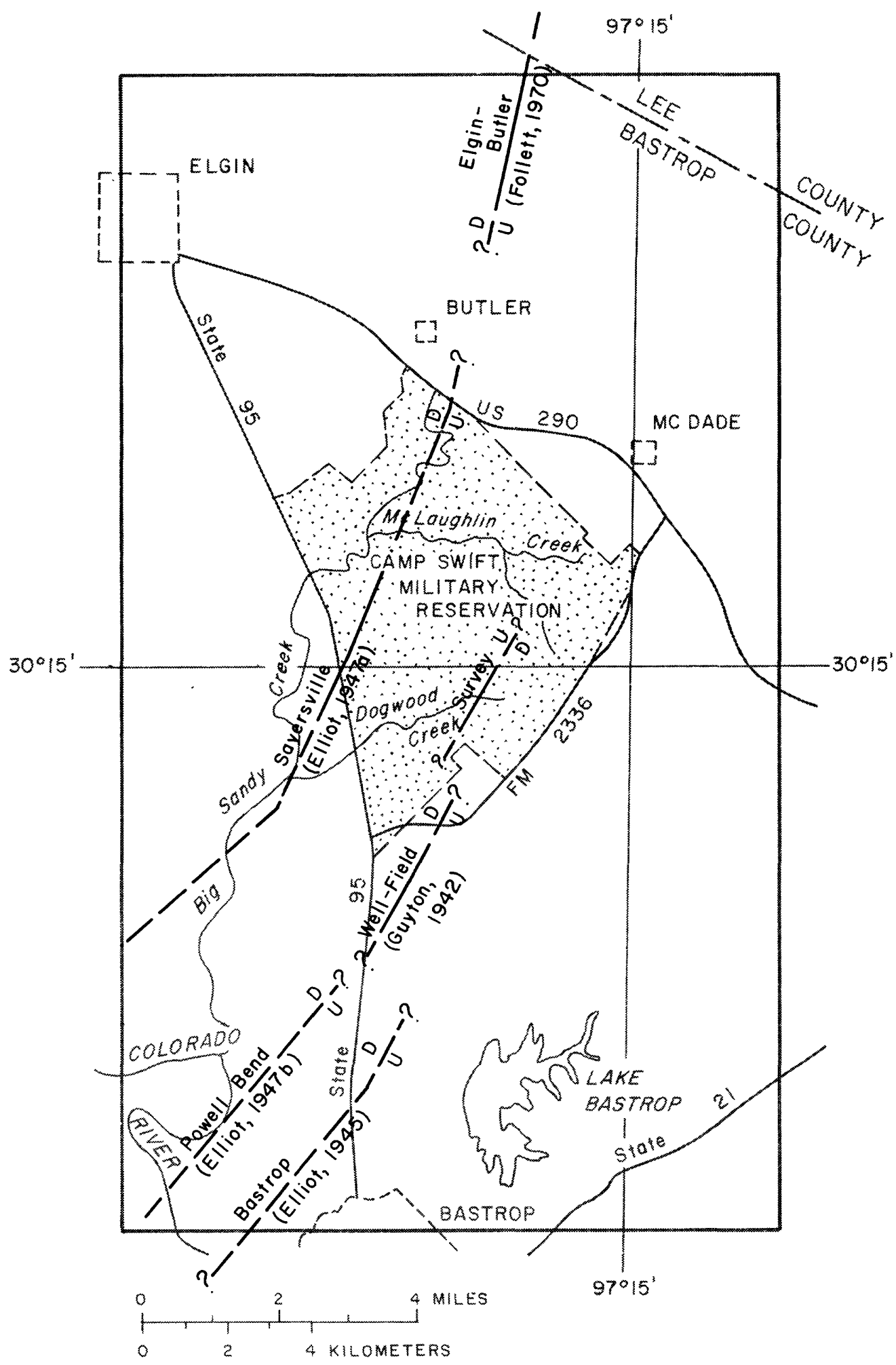

EXPLANATION

$\frac{\text { Well-Field }}{(\text { Guyton, 1942) }} \frac{U}{D}$

FAULT-- $U$, upthrown side; $D$, downthrown side. Dashed where approximately located. Author and date refer to publication where fault has been mapped or reported. Fault name, for example, "Well-Field", refers to a designated name of the fault for identification

Figure 2.3-2.--Location of faults in or near Camp Swift. 


\subsection{GENERAL FEATURES--Continued}

\subsection{Structural Features--Continued}

The Lower Colorado River Authority drilled numerous test holes on the Camp Swift Military Reservation. Most of the test holes penetrated the Calvert Bluff Formation and the upper few feet of the Simsboro Forination. These test hole data were used to construct structural strike and dip sections shown in figure 2.3-3. These sections show a difference in ignite occurrence and geometry in the lower and upper parts of the Calvert $B l$ uff.

The lower part of the Cal.art Bluff section contdins two lignite seams, which usually occur from 6 to 35 feet above the top of the uppermost sand of the Simsboro Formation. Within the Camp Swift area, these lignite seams appear to be widespread in both the strike and dip directions. The confining beds of clay, which underlie these lignite searis in most places, appear to pinch out in some areas and grade into slightly more permeable beds such as sandy clay, silt, or clayey sand. In a few places the confining beds are absent and the lignite is in contact with the Simsboro Formation (see strike section $\left.A-A^{\prime}\right)$.

The upper part of the Calvert Bluff contains dip-oriented sand bodies which merge and become stacked. In this upper part, the lignite occurs in discontinuous seams in both strike and dip directions. The number of lignite seams increases with distance from the channel-sand deposits. The differences in iignite occurrence and geometry in the upper and lower parts of the Calvert Bluff section indicate a genetic break within the formation.

The dip section $B-B^{\prime}$ crosses the Sayersville fault, which here is estimated as having about 250 feet of throw. This interpretation of faulting is supported by the fact that the outcrop of the Calvert Bluff Formation is as much as 4 to 5 miles wider than would be expected from an unfaulted outcrop. The wider than normal outcrop indicates a repetition of the section by down-to-the-northwest faulting. About 250 feet of the lower part of the Calvert Bluff contacts about 250 feet of the upper part of the simsboro at the fault plane. 


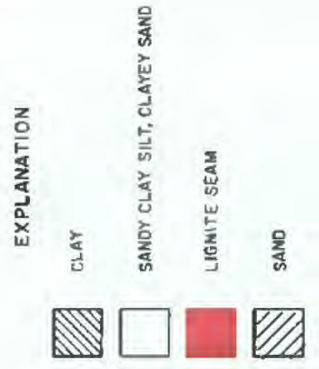

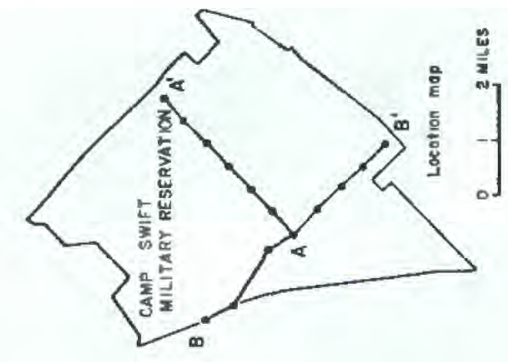

点

$-\frac{9}{4}$

\%

$4 \frac{9}{3}$

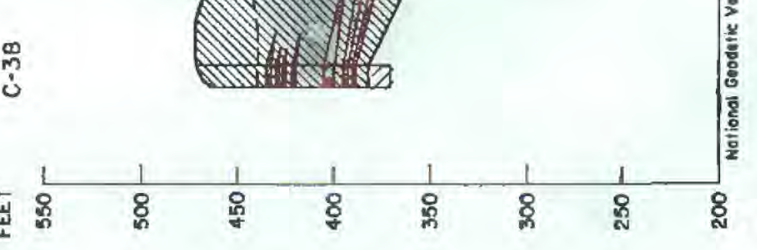

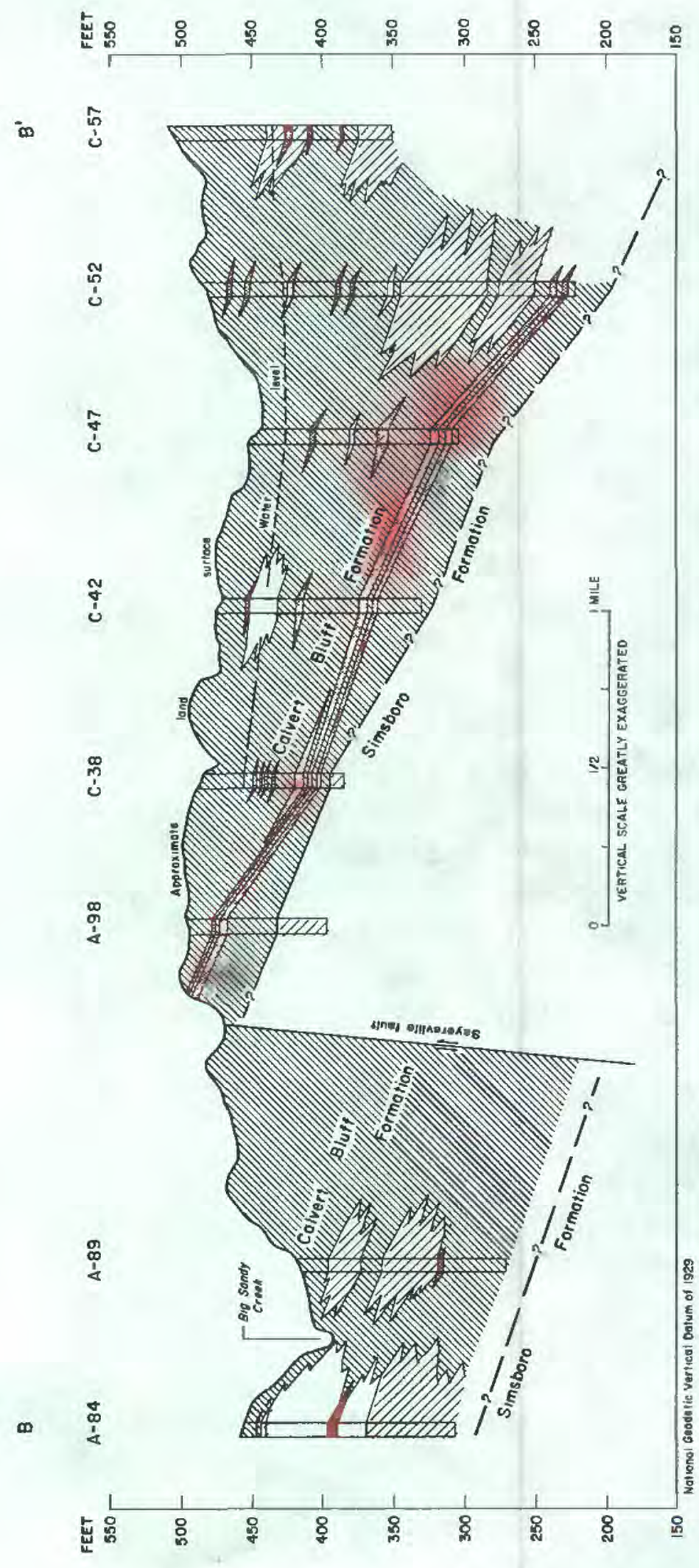

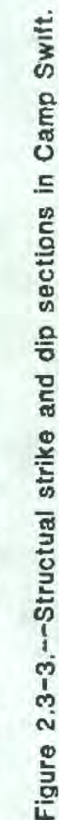




\subsection{GENERAL FEATURES}

2.4 Climate

\section{CAMP SWIFT AREA CHARACTERIZED BY TEMPERATE CLIMATE}

The climate of the Camp Swift area is controlled by its geographic location and physiography.

The climate of the Camp Swift area is affected by the Balcones Escarpment, a prominent topographic break in altitude about 30 miles west of Camp Swift. This escarpment separates the deeply dissected limestone terrain of the Edwards Plateau on the west from the lower-lying clay and sand terrain of the Gulf Coastal Plain on the east (Baker, 1975). The climate of areas to the east of the escarpment generally is classified as warm, humid, and subtropical.

In the study area, precipitation varies from month to month, but usual$1 y$ is greater during April, May, and September when mean monthly precipitation exceeds 4.0 inches. During these months, convective thunderstrom activity and movement of mositureladen air along the tropical Gulf storm tract are responsible for much of the precipitation. The Balcones Escarpment is an orographic barrier to the warm, easterly, tropical air currents. As these air currents rise over the escarpment, they become less stable and produce rain. Severe storms commonly result when an atmospheric pressure surge from the northeast and a warm easterly trough of air arrive at the escarpment simul- taneously. These types of storms have the potential of producing $c a-$ tastropic volumes of rain.

The 30-year mean-annual precipitation from 1941 to 1970 , as recorded at the city of Smithville about 12 miles southeast of the study area, is 36.82 inches. Total annual precipitation, however, may vary considerably from year to year. The driest year on record was in 1956 with 17.94 inches of precipitation, and the wettest year was in 1957, with 59.35 inches. The distribution of mean monthly precipitation and mean month1y temperature for the Smithville weather station is shown in figure 2.4-1. The record monthly precipitation extremes (maximums and minimums) are al so given to show the large variations amoung the means and extremes.

Daily precipitation data are published monthly as "Climatological data for Texas" by the National Oceanic and Atmospheric Administration, National $\mathrm{Cl}$ imatic Center, Asheville, North Carolina. Statistical information concerning analyses of rainfall data is presented in Hershfield (1961). 

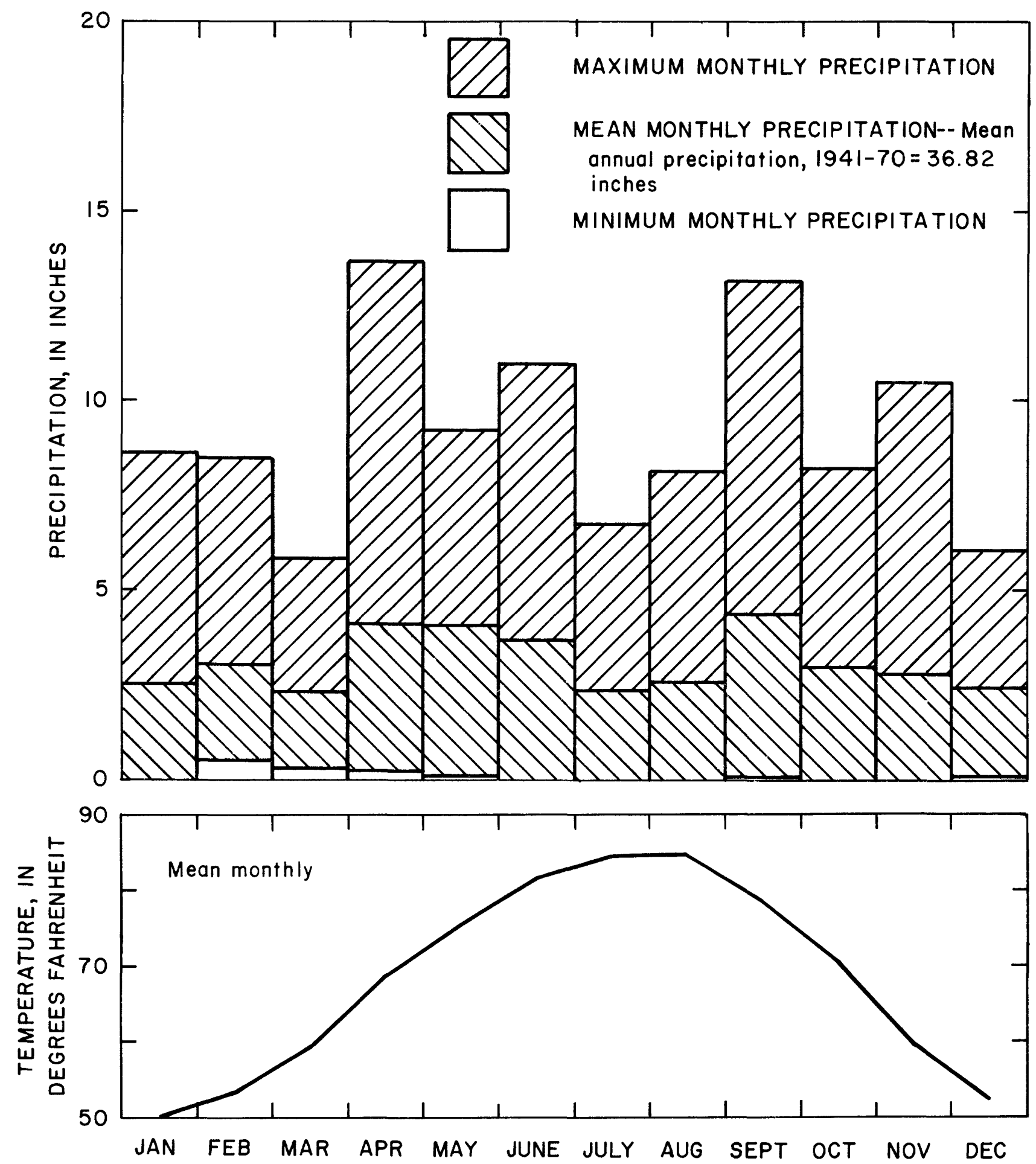

Figure 2.4-1.--Mean monthly temperature and precipitation at Smithville. 


\subsection{GENERAL FEATURES--Continued}

\subsection{Soils}

\section{SOILS GENERALLY HAVE MOUERATE TO SIGNIFICANT EROSION POTENTIAL}

Two main soil groups, the Axtell-Tabor-Crockett group and the PatiloDemona-Silstid group, overlie the Camp Swift Military Reservation.

Two main soil groups, the Axtel1Tabor-Crockett group in the southern part of Camp Swift and the PatiloDemona-Silstid group in the northern part (fig. 2.5-1) overlie Camp Swift. Axtell-Tabor-Crockett soils are generally flat to steeply sloping soils. They are characterized by a loamy surface layer and slightly to very slightly permeable lower layers. These lower layers range in composition from clay to sandy clay, commonly are acidic, and have considerable shrink-swell potential. The hazard of erosion for the Axtell-Tabor-Crockett group is moderate to significant, and gullies commonly are formed. This group of soils generally is found on stream terraces and uplands. The Dogwood Creek and McLaughl in Creek drainage basins are in the area of Axtell-Tabor-Crockett soils.

Patilo-Demona-Silstid soils are slightly to steeply sloping. These soils have a sandy surface layer and lower layers of mostly mottled sandy clay loam. The lower layers tend to be acidic and have a minimal shrinkswell potential. The top layer of the soils in the Patilo-DemonaSilstid group is very perineable whereas the lower layers are less permeable. The hazard for erosion is slight to moderate. These soils commonly are found on the uplands. In the Camp Swift Reservation, Big Sandy Creek flows through an area dominated by the Patillo-Demona-Silstid soil group.

The soils along the downstream reaches of the creek beds consist of clay loam to fine sand. These soils generally have a reaction value $(p H)$ close to neutral, a mininal shrinkswell potential, slopes less than $1^{\circ}$, and are subject to frequent flooding. Detailed descriptions of the soils in the Camp Swift area can be obtained from Baker (1979). Included with the descriptions are pertinent engineering properties of the soils. 


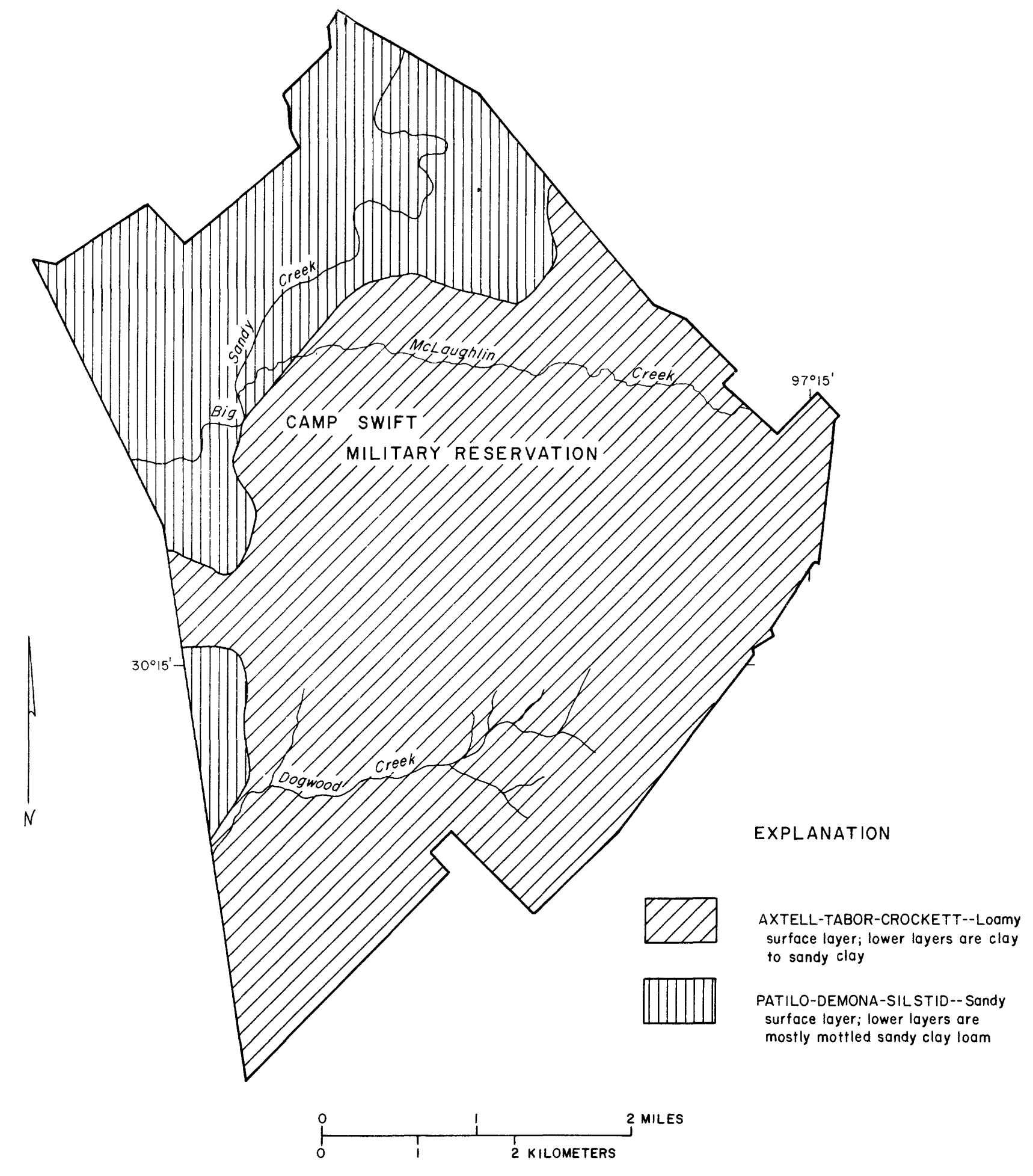

Modified from Baker, (1979)

Figure 2.5-1.--Soils map. 


\title{
2.6 Surface Drainage
}

\author{
VIRTUALLY ALL OF CAMP SWIFT IS IN THE BIG SANDY CREEK DRAINAGE BASIN \\ The drainage of Big Sandy Creek reaches the Colorado River \\ about 8 miles south of the study area.
}

\begin{abstract}
Most of the Camp Swift Military Reservation is within the Big Sandy Creek drainage basin. Only very small areas along the southeastern boundary of Camp Swift are drained by Piney Creek. Two tributaries, Dogwood Creek and McLaughlin Creek, convey runoff from the Camp Swift area to Big Sandy Creek (fig. 2.6-1).

Although Big Sandy Creek general$1 y$ is regarded to be a perennial stream, it has stopped flowing during long periods of less-than-normal precipitation. As an example, recordsetting temperatures and very dry conditions occurred during the summer of 1980, and the Geological Survey's streamflow station, Big Sandy Creek near Elgin, recorded 61 days of no flow during the 1980 water year (October 1979 to September 1980). Most of these no-flow periods were during July, August, and September. Additional information on stream discharge is presented in Sections 4.2 and 10.2 .
\end{abstract}

Dogwood Creek, a small tributary to Big Sandy, originates in the Camp Swift Military Reservation. Dogwood Creek is intermittent, flowing only after storms. During the 1980 water year, Dogwood Creek flowed for only 25 days.

McLaughl in Creek al so is intermittent. The flow of this creek is not gaged independently, but its flow is included in the runoff at the Geological Survey's gaging station, Big Sandy Creek near Elgin. (See section 4.2). McLaughl in Creek joins Big Sandy Creek about $0.7 \mathrm{mile}$ up stream from this gage.

The major drainage areas within the Camp Swift Military Reservation slope southwesterly and westerly from altitudes of more than 500 feet near the headwaters of Dogwood and McLaughlin Creeks to an altitude of 400 feet where Big Sandy Creek crosses State Highway 95. The highest altitude is slightly more than 550 feet along the southeastern boundary of the Reservation near Farm-to-Market Road 2336 (fig. 2.6-1). 
Ground-water consumers used 2.7 million gallons per day during 1980.

The source of water for domestic use in the study area is water from the Wilcox Group. The total water pumped from the Wilcox by major users in 1980 was 2.7 million gallons per day. About 50 percent of this total was for municipal use, 47 percent was for rural residents on watersupply systems, and 3 percent was for industry and research facilities. Ground-water withdrawals by the principal users from 1978-80 are given in table $3 \cdot 0-1$, and the location of these withdrawals is shown in figure 3. 0-1.

Lake Bastrop is the only major artificial impoundment of surface water in the area. The lake is used for cooling-water supply and for recreation, and is not used as a municipal water supply. The average annual withdrawal of 10,750 acre-feet (9.6 million gallons per day) of water from the lake is used in a steam electric-generating plant (Dowell and Petty, 1971). Except for consumptive losses, the water is returned to the lake.

Future lignite mining in the Camp Swift area will be another principal use of ground water. Dewatering the lignite-bearing sediments adjacent to the mined area in order to lower water levels in the Calvert Bluff Formation will withdraw large volumes of water from this formation. Hydrologic depressuring of the Simsboro aquifer beneath the mined area also may be necessary to prevent upheaval of the mine floor. This depressuring would involve the removal of large quantities of water from the Simsboro. Using a two dimensional finite-difference ground-water model, Hall (1981) estimated that removal of as m!:ch as 7.3 million gallons per day during 30 years of mining may be necessary just to depressurize the Simsboro aquifer. Possibly much of this water that is withdrawn during the mining process could be transported to nearby cities or other places of need.

Table 3.0-1.--Annual ground-water pumpage by major users, 1978-80, in million gallons per day

[Pumpage is shown by user, to the nearest 0.01 million gallons per day. Totals are rounded to two significant figures]

\begin{tabular}{|c|c|c|c|}
\hline User & 1978 & $\begin{array}{l}\text { Year } \\
1979 \\
\end{array}$ & 1980 \\
\hline $\begin{array}{l}\text { Aqua Water Supply Corp. } \\
\text { City of Bastrop } \\
\text { City of Elgin } \\
\text { Elgin-Butler Brick Co. } \\
\text { City of McDade } \\
\text { (Bastrop Water Control and } \\
\text { Improvement District) }\end{array}$ & $\begin{array}{c}-- \\
1.56 \\
.42 \\
-\overline{.02}\end{array}$ & $\begin{array}{r}0.96 \\
.86 \\
.43 \\
.03 \\
.02\end{array}$ & $\begin{array}{r}1.28 \\
.82 \\
.53 \\
.03 \\
.02\end{array}$ \\
\hline Texas Rendering Company, Inc. & .04 & .04 & .03 \\
\hline Totais & 2.0 & 2.3 & 2.7 \\
\hline
\end{tabular}




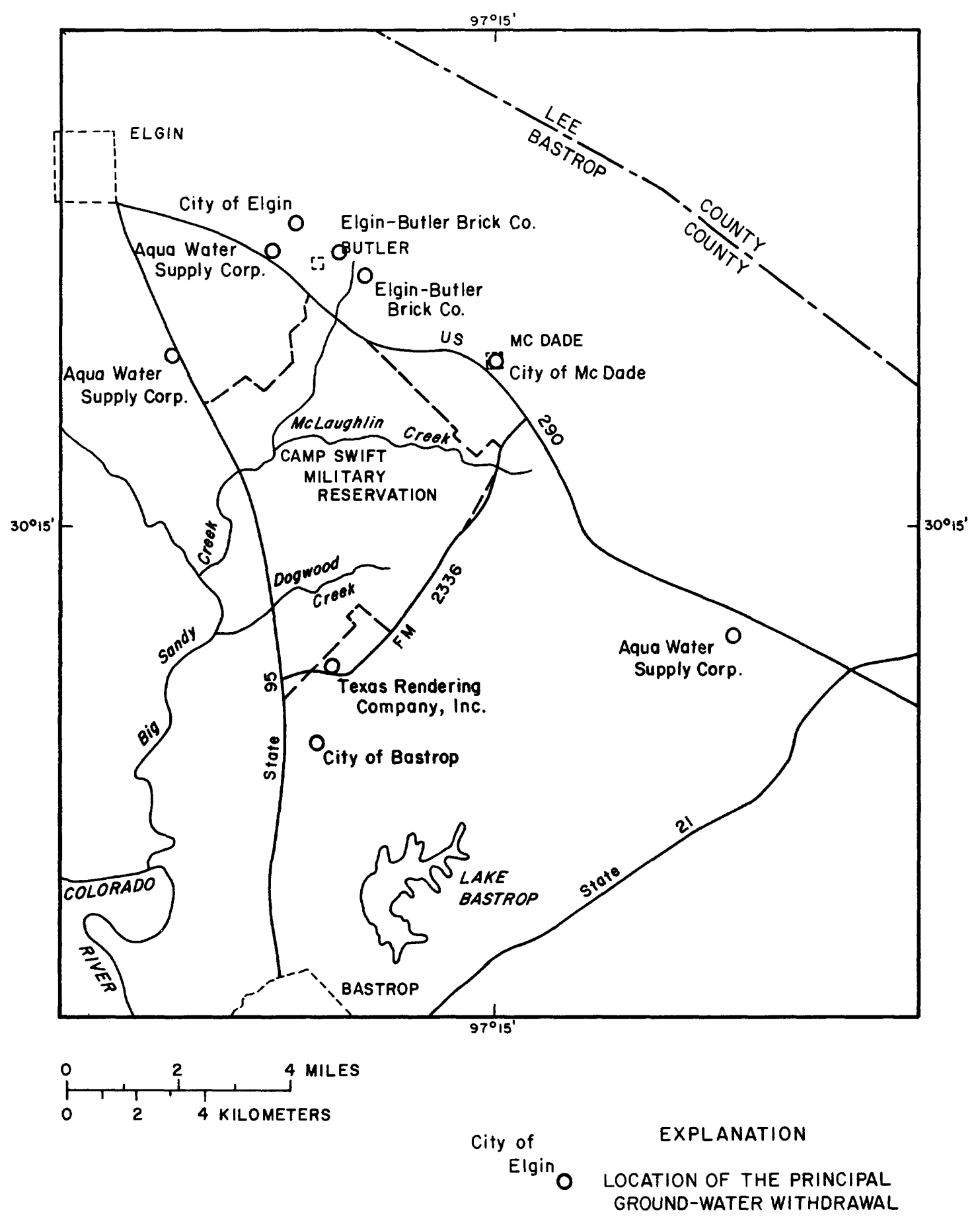

Figure 3.0-1.--Location of the principal ground-water withdrawal sites and user near Camp Swift. 
4.0 HYDROLOGIC NETWORKS

\subsection{Ground Water}

INFORMATION ON GROUND WATER IS AVAILABLE FOR ABOUT 200 LOCATIONS

The U.S. Geological Survey established a network of 22 wells for obtaining monthly water-level information; previous investigations provide historical data on water levels.

The ground-water monitoring network in the study area provides waterlevel and ground-water-quality data prior to mining. These background data will aid the future mine owner and operator, consulting engineers, and the regulatory agencies in determining the effects of lignite mining on the ground-water resources of the area.

An inventory of about 200 wells and test holes is presented in section 10.1 , and the location of these hydrologic sites is shown in figure 4.1-1. The site identification number, depth of well, producing formation, water level and date of water-level measurement, and other available information for each site are given in the section 10.1. Detailed waterquality information, which is available for 13 wells in the study area is presented in section 7.1 . 


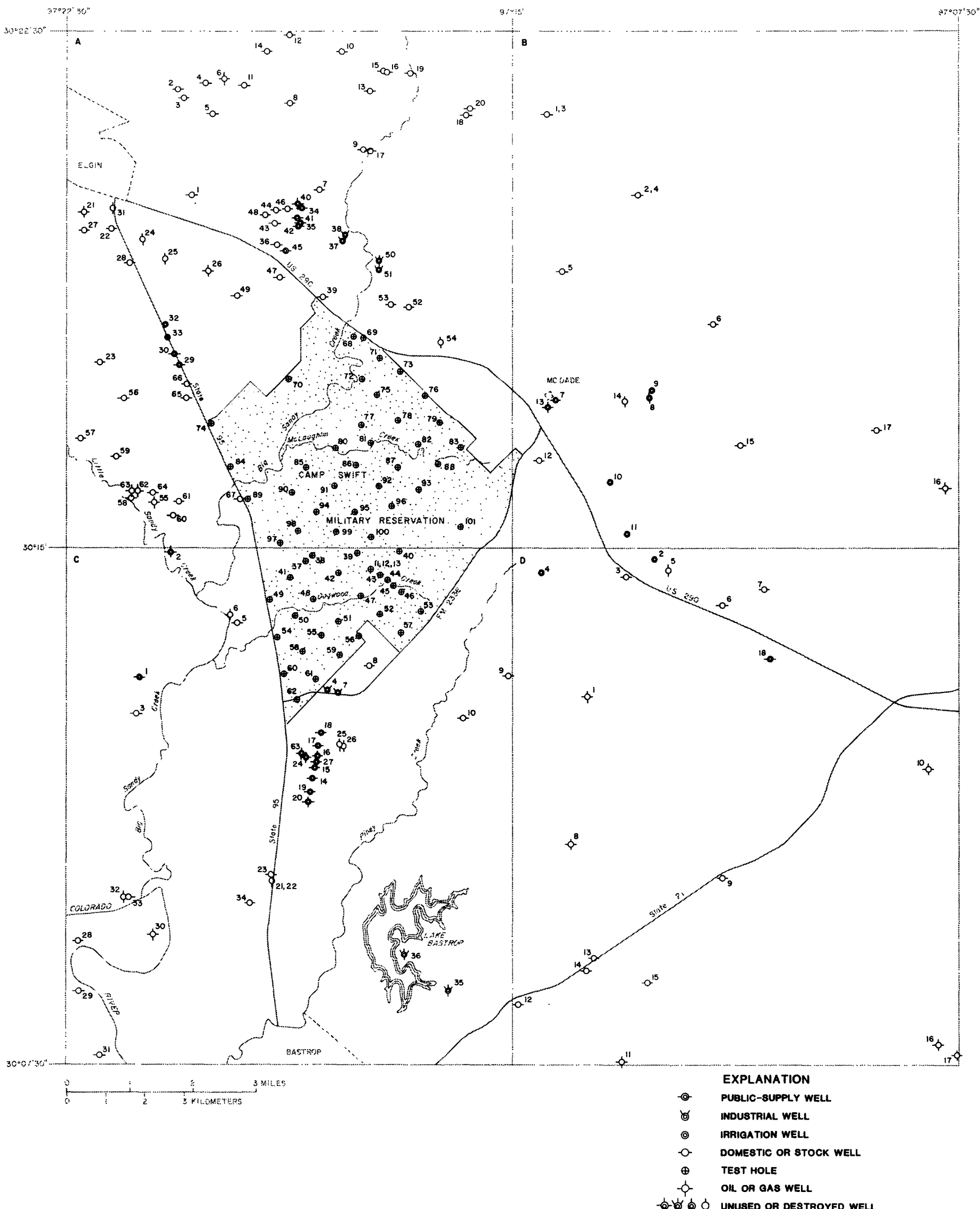

Figure 4.1-1.--Location of wells and test holes. 
4.0 HYDROLOGIC NETWORKS--Continued

\subsection{Ground Water--Continued}

Twenty-two wells in the study area were monitored monthly by the Geological Survey for water-level fluctuations in the Hooper, Simsboro, and Calvert Bluff Formations. Most of the wells had slight and generally insignificant water-level changes from May 1980 to May 1981. This information is presented in table 4.1-1. Previous investigations and well inventories provided historical data on water levels and geological information. 
Table 4.1-1.--Monthly water-level measurements of observation wells, 1980-81 1 /

\begin{tabular}{|c|c|c|c|c|c|c|c|c|c|c|c|c|c|}
\hline \multirow[b]{2}{*}{$\begin{array}{c}\text { Well } \\
\text { number }\end{array}$} & \multicolumn{13}{|c|}{ Depth below land surface (feet) } \\
\hline & May & June & July & Aug. & $\begin{array}{l}1980 \\
\text { Sept. }\end{array}$ & oct. & Nov. & Dec. & Jan. & Feb. & $\begin{array}{l}1981 \\
\text { Mar. }\end{array}$ & April & May \\
\hline A- 8 & 6.8 & 7.3 & 9.0 & 9.5 & 9.5 & 9.5 & -- & 9.8 & 10.3 & -- & -- & 9.3 & 9.8 \\
\hline$A-20$ & 61.8 & 53.4 & 52.9 & 52.5 & 52.5 & 52.5 & -- & 52.8 & 52.3 & -- & -- & 52.2 & 52.2 \\
\hline$A-30$ & 141.1 & 145.4 & 164.4 & 161.3 & 163.2 & 162.2 & -- & 161.2 & -- & -- & -- & -- & 147.5 \\
\hline$A-33$ & 7.9 & 5.6 & 10.2 & 11.6 & 13.6 & 13.7 & -- & 15.1 & 16.2 & -- & -- & 12.3 & 11.9 \\
\hline$A-35$ & 48.2 & -- & 59.9 & 60.6 & 56.5 & 53.5 & -- & 52.1 & 49.7 & -- & - & 50.6 & 48.9 \\
\hline$A-39$ & 16.6 & 17.8 & 18.3 & 17.5 & 17.6 & 17.3 & -- & 17.2 & 17.1 & -- & -- & 17.5 & 17.5 \\
\hline$A-45$ & 146.7 & -- & 154.3 & 168.5 & 168.3 & 167.3 & - & 166.3 & -- & -- & -- & 168.5 & -- \\
\hline$A-52$ & 57.8 & 58.9. & 63.0 & 58.8 & 59.4 & 59.6 & - & 58.3 & 58.8 & -- & -- & 57.2 & 58.4 \\
\hline$A-61$ & 64.3 & 63.7 & 63.7 & 63.9 & 66.1 & 64.1 & -- & 63.4 & 64.2 & -. & -- & 64.6 & 64.5 \\
\hline$A-62$ & -- & 16.1 & 16.5 & 16.8 & 16.7 & 16.8 & -- & 16.8 & 16.6 & - & - & 16.5 & - \\
\hline$A-65$ & 69.1 & 71.1 & 102.1 & 101.6 & 103.3 & 104.6 & -- & -- & 97.4 & 97.1 & - & 97.1 & -- \\
\hline C- 2 & 49.1 & 54.4 & 59.3 & 49.5 & 52.3 & 47.0 & -- & 43.8 & 45.1 & - & - & 55.1 & 58.8 \\
\hline C- 4 & 159.1 & -- & 163.1 & 160.1 & 160.4 & 158.7 & -- & 156.6 & 157.7 & 155.4 & -- & 157.3 & 125.2 \\
\hline C- 7 & 145.3 & 148.6 & 152.2 & 149.5 & 148.7 & 147.5 & -- & 145.1 & 146.8 & 145.6 & -- & 146.8 & - \\
\hline C- 9 & 109.1 & 109.9 & 128.2 & 110.9 & 110.8 & 111.0 & -- & 108.5 & 109.3 & - & -- & 110.4 & 111.9 \\
\hline$C-10$ & -- & 141.4 & 146.5 & 146.0 & 146.0 & 146.1 & -- & 145.5 & 146.5 & -- & - & 147.5 & 145.9 \\
\hline$C-11$ & -- & -- & -- & -- & -- & -- & -- & -- & 103.5 & 103.3 & -. & 94.6 & 91.1 \\
\hline C-12 & -- & -- & -- & -- & $=-$ & -- & -- & -- & 54.1 & 56.3 & -- & 60.1 & 60.8 \\
\hline$C-13$ & -- & -- & -- & -. & -. & -- & -- & -- & 107.0 & 106.0 & -- & 106.2 & 108.0 \\
\hline$C-16$ & -- & 137.5 & 141.5 & 130.5 & 128.9 & 123.1 & -- & 117.0 & 126.1 & 117.7 & -- & 121.6 & -- \\
\hline$C-17$ & -- & 133.0 & 137.8 & - & 127.2 & 123.4 & -- & 119.1 & -- & 119.1 & -- & 123.1 & -- \\
\hline$C-25$ & 21.6 & 21.2 & 21.4 & 21.7 & 21.7 & 21.3 & -- & 21.4 & 21.5 & -- & -- & 21.7 & 19.5 \\
\hline
\end{tabular}

1f See section 10.1 for water-level measurements of additional wells. 
4.0 HYDROLOGIC NETWORKS--Continued

\subsection{Surface Water}

FOUR STREAMFLOW GAGES, FOUR AUTOMATED WATER-QUALITY SAMPLERS, AND

FIVE RECORDING RAIN GAGES WERE OPERATED IN THE CAMP SWIFT AREA

$$
\frac{\text { The U.S. Geological Survey's surface-water data-collection }}{\frac{\text { network for the study area was established in } 1979 \text { to }}{\text { obtain background information in advance of }}}
$$

Information on streamflow and surface-water quality is available for four sites in the Camp Swift area. The location of the surfacewater hydrologic instruments with relation to the proposed mining area is shown in figure 4.2-1. Each streamflow station marks the location of a surface-water-quality sampling site. Definitions for selected surface-water related terms are given in section 11.2.

The four streamflow gages are located on two creeks that cross Camp Swift. Two continuous-record streamflow stations are on Big Sandy Creek. Station 08159165 is upstream and station 08159170 is downstream from the proposed mining area. Two floodhydrograph partial-record stations are on Dogwood Creek, a tributary to Big Sandy Creek. The flood-hydrograph partial-record stations record flow only above a predetermined baseflow, and thus do not record low flows. Station 08159180 is inside Camp Swift near the headwaters of Dogwood Creek, and station 08159185 is downstream from the proposed mining area. This network provides a means of comparing flow characteristics upstream and downstream from future mining activity. The daily mean discharges for the two continuous-record gaging stations are given in section 10.2 . 


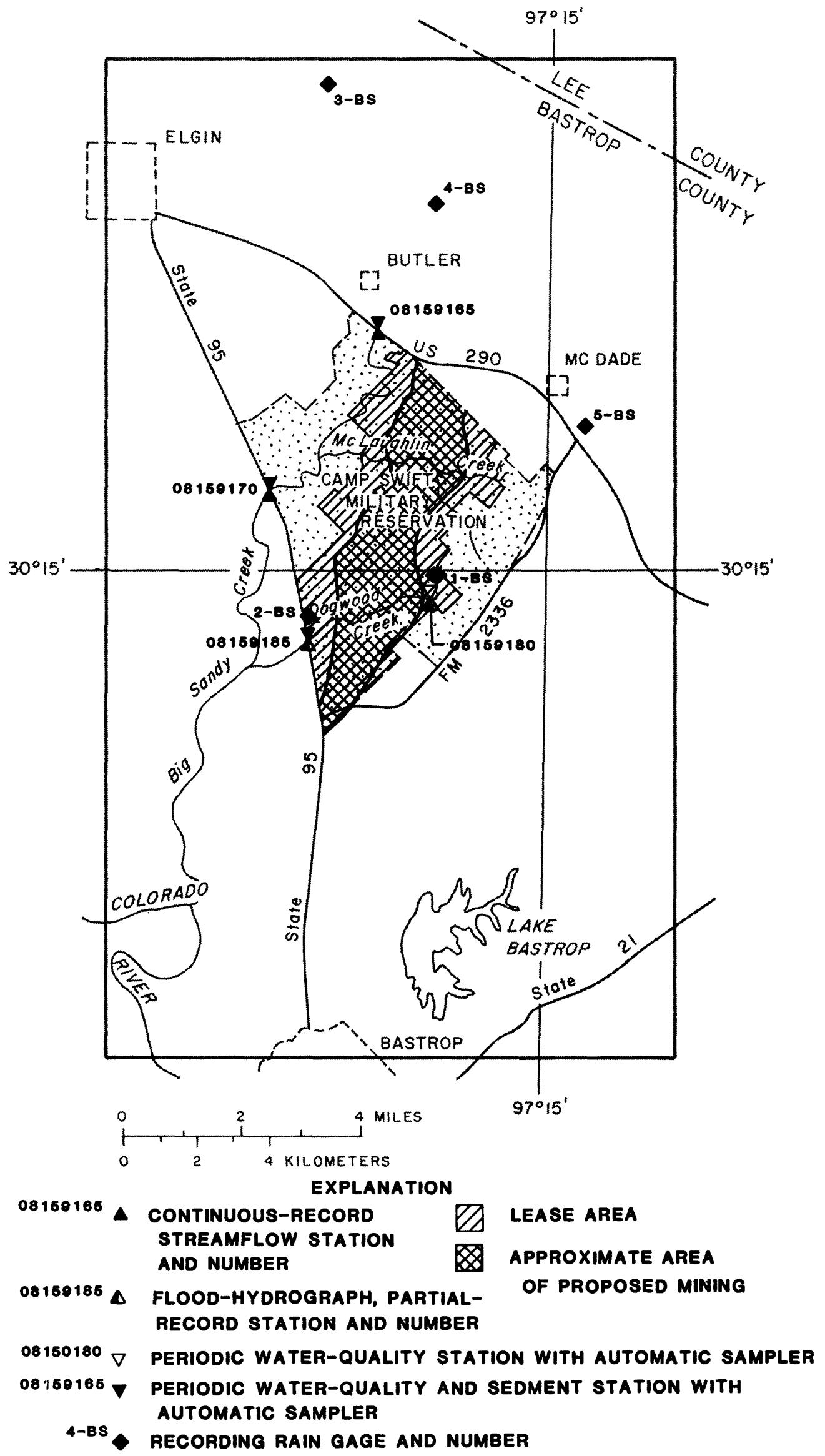

Figure 4.2-1.--Location of surface-water stations and rain gages. 


\subsection{Surface Water--Continued}

Automated water samplers were activated at a predetermined stage and collected discrete water-quality samples at predetermined time intervals. This schedule of sampling defines the range of water-quality characteristics of the stream for the duration of a storm. Water-quality analyses for the four streamflow stations are presented in section 10.3 .

Five recording rain gages are located in the study area. These gages record the depth of precipitation at time increments of 15 minutes. The rain gages are located strategically so that the rainfall may be compared with the corresponding runoff at the streamflow-gaging stations. The daily total rainfall for these gages is given in section 10.4. The monthly and annual weighted-mean precipitation that applies to the two continuous-record streamflow stations are shown with the streamflow data for those stations in section 10.2.

Weighted-mean precipitation factors for each streamflow station are shown in table 4.2-1 from which the weighted-mean precipitation for a streamflow station may be determined. For example, the weighted-mean precipitation for the watershed contributing to flow at the Big Sandy Creek near McDade streamflow station (08159165) could be computed as follows: Multiply the recorded precipitation at rain gage 3 -BS by 0.57 and add the the recorded precipitation at rain gage 4-BS multiplied by 0.43 . 
Table 4.2-1.--Weighted-mean precipitation factors for watersheds monitored by streamflow gaging stations

\begin{tabular}{|c|c|c|c|}
\hline $\begin{array}{l}\text { Station } \\
\text { number }\end{array}$ & Station name & Rain gage & $\begin{array}{l}\text { Weighted-mean } \\
\text { precipitation } \\
\text { factor }\end{array}$ \\
\hline 08159165 & $\begin{array}{l}\text { Big Sandy Creek near } \\
\text { McDade }\end{array}$ & $\begin{array}{l}3-B S \\
4-B S\end{array}$ & $\begin{array}{r}0.57 \\
.43\end{array}$ \\
\hline 08159170 & $\begin{array}{l}\text { Big Sandy Creek near } \\
\text { Elgin }\end{array}$ & $\begin{array}{l}3-B S \\
4-B S \\
5-B S\end{array}$ & $\begin{array}{l}.36 \\
.38 \\
.26\end{array}$ \\
\hline 08159180 & $\begin{array}{l}\text { Dogwood Creek near } \\
\text { McDade }\end{array}$ & $1-B S$ & 1.00 \\
\hline 08159185 & $\begin{array}{l}\text { Dogwood Creek at State } \\
\text { Highway } 95 \text { near } \\
\text { McDade }\end{array}$ & $\begin{array}{l}1-B S \\
2-B S\end{array}$ & $\begin{array}{l}.70 \\
.30\end{array}$ \\
\hline
\end{tabular}


STREAMFLOW VARIES WITH RAINFALL ANU SUIL MUISTURE

Variations in streamflow are related to the duration and intensity of rainfall and the antecedent precipitation index.

A typical pattern of daily streallflow for Big Sandy Creek near Elgin (08159170) for January through April 1981 is shown in figure 5.0-1. The daily total rainfall for that period also is shown in the figure. This figure shows that the flow of Big Sandy Creek fluctuates very rapidly in response to rainfall in the watershed. Because the drainage ared of Big Sandy Creek is relatively small, the duration of surface runoff from most storms is short, and the base flow of Big Sandy Creek is small, usually less than 0.5 cubic foot per second. Consequently, evapotranspiration probably has very little effect on the floodflows of this creek.
The soil characteristics of this area, which are discussed in section 2.5, have a significant effect on streamflow. Because the shrink-swell potential, permeability, and moisture content of these soils vary greatly in relation to antecedent precipitation, the runoff characteristics for a given storm can vary accurdingly. After prolonged dry periods, the absorption characteristics of the soils can be very large, and thus the surface runoff can be small. During wet periods, water storage capacity of the soils is greatly decreased, and thus surface runoff may be relatively large. 

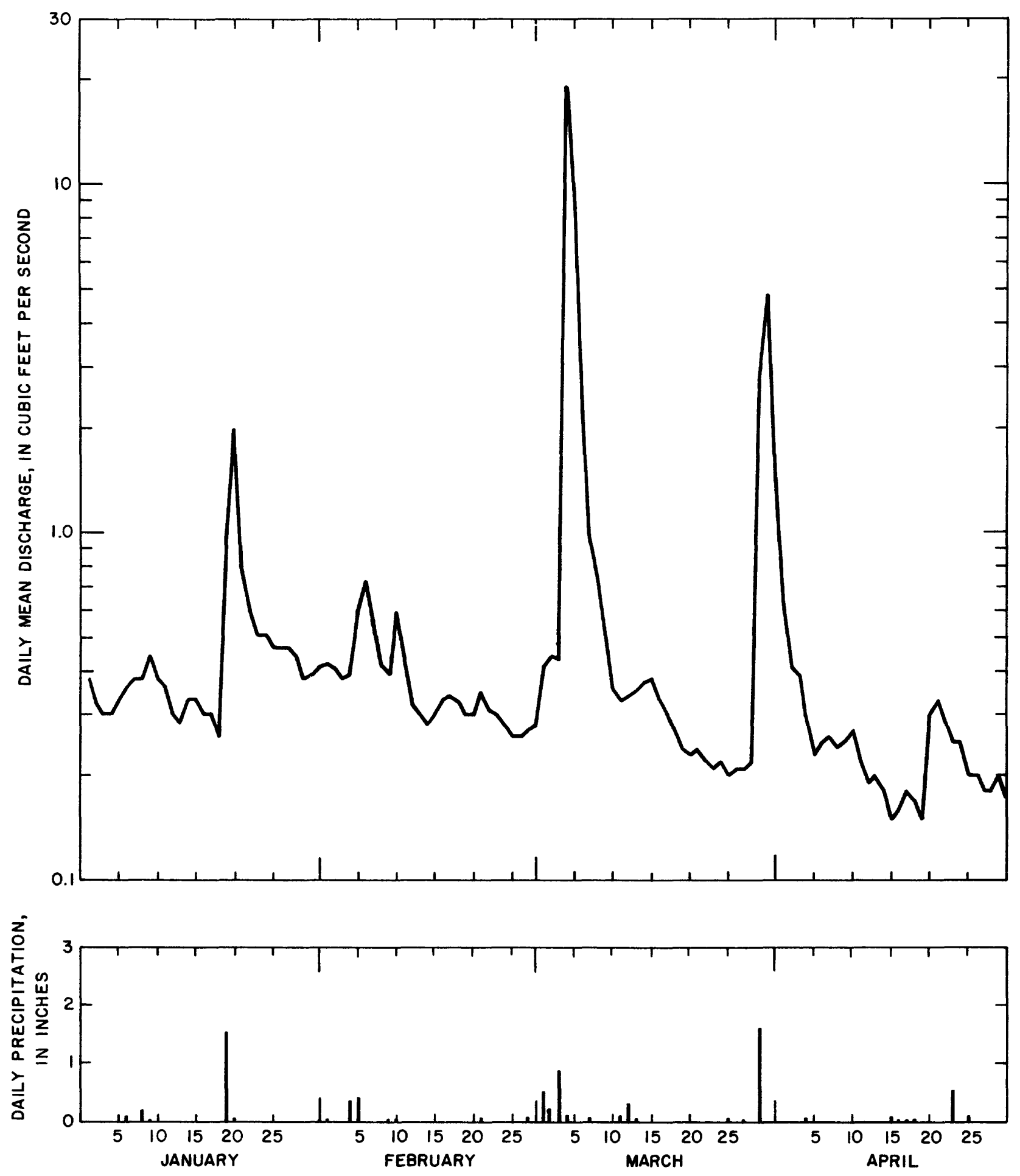

Figure 5.0-1.--Typical daily pattern of streamflow, Big Sandy Creek near Elgin (08159170), January-April 1981. 
Hydrographs of incremental precipitation and runoff for eight selected storms at the four streamflow stations on Big Sandy and Dogwood Creeks are shown in figure 5.0-2. Three storms were analyzed for each of the two continuous-record streamflow stations on Big Sandy Creek, and one storm was analyzed for each of the two flood-hydrograph, partialrecord streamflow stations on Dogwood Creek. 

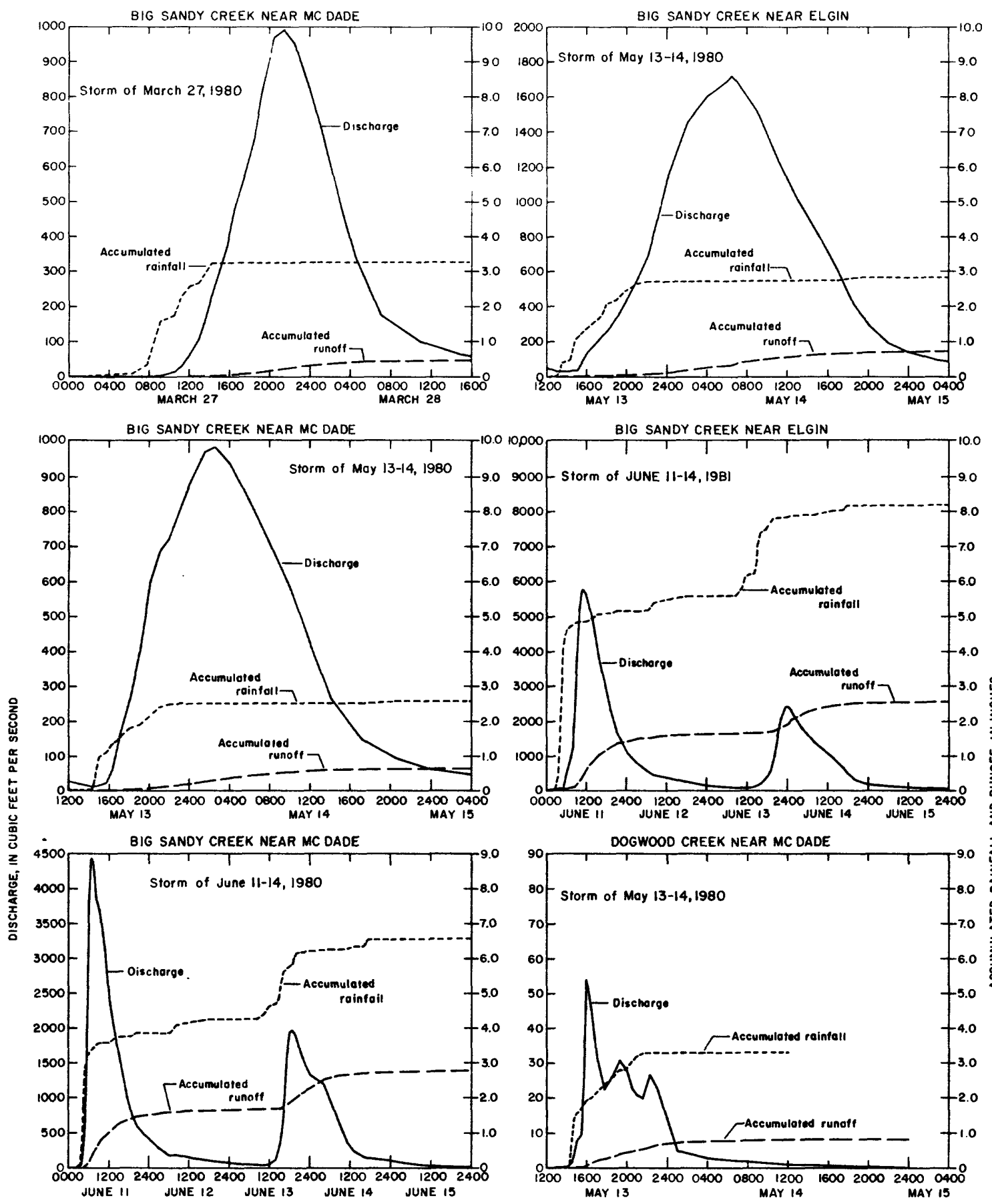

BIG SANDY CREEK NEAR ELGIN
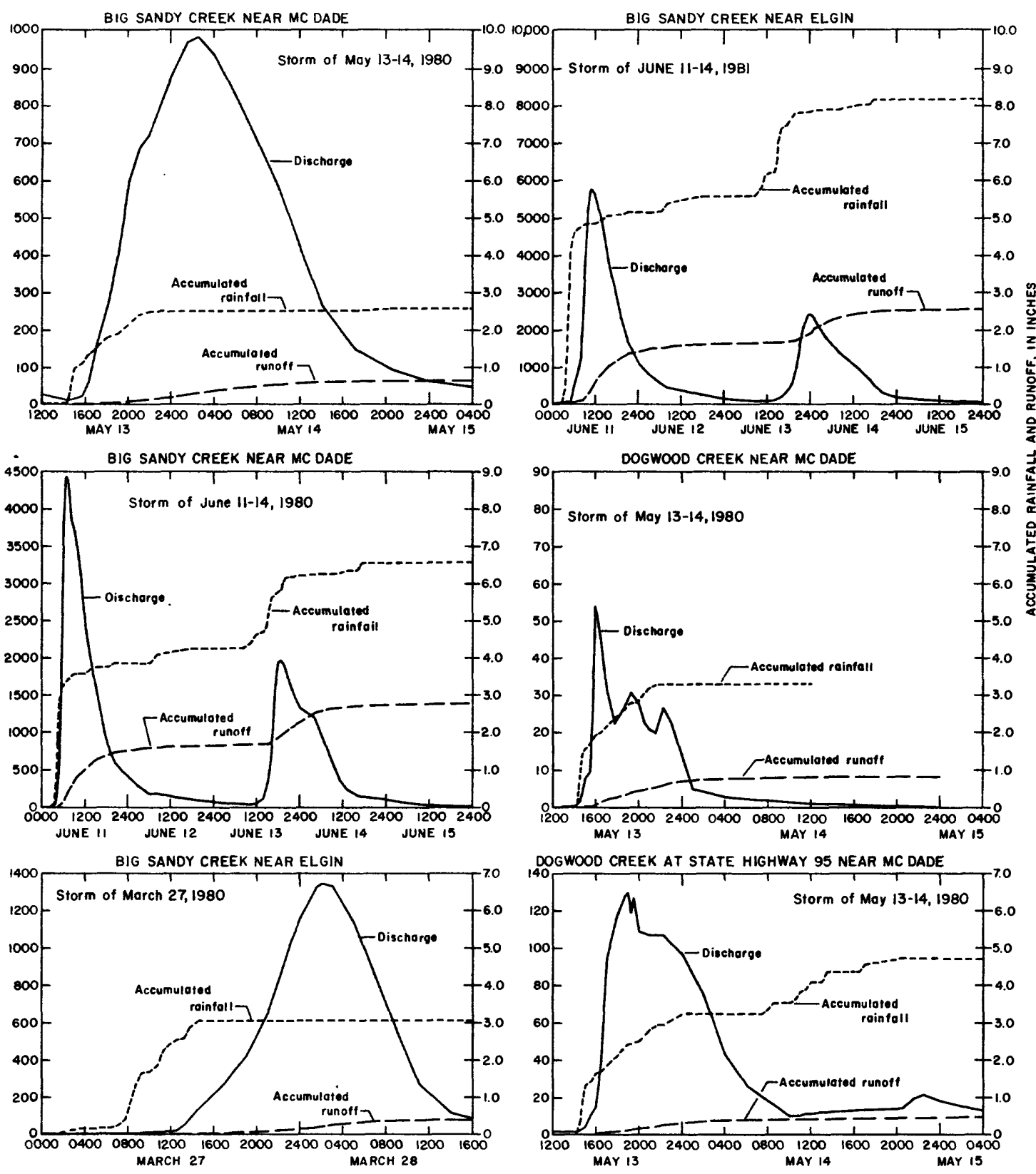

Figure 5.0-2.--Hydrographs and mass curves for four streamflow stations on Big Sandy and Dogwood Creeks. 
Selected characteristics of the precipitation and runoff for these storms are summarized in table 5.0-1. The incremental values of precipitation and runoff for these storms are given in section 10.5. The incremental precipitation for selected storms at rain gages and the weighted-mean precipitation within the Big Sandy and Doawood Creek watersheds also are shown in the table for each streamflow site. Also presented in the table are accumulated rainfall and runoff volumes expressed in inches of depth over the entire drainage watershed. Expression of precipitation and runoff in the same units allow direct comparison. For example, if a storm produces a weighted-mean precipitation of 1.00 inch and the accumulated runoff is 0.30 inch, then the runoff would be 30 percent of the precipitation.

Table 5.0-1.--Storm rainfall-runoff data, Big Sandy and Dogwood Creeks

\begin{tabular}{|c|c|c|c|c|c|c|c|c|}
\hline $\begin{array}{l}\text { Date of } \\
\text { storm }\end{array}$ & $\begin{array}{l}\text { Duration } \\
\text { (hours) }\end{array}$ & $\begin{array}{l}\text { Total } \\
\text { (inches) }\end{array}$ & $\begin{array}{c}\text { RainfaT } \\
\text { Maximum } \\
\text { T5 min- } \\
\text { ute }\end{array}$ & $\begin{array}{c}\text { Tncrement } \\
\begin{array}{c}30 \min ^{-} \\
\text {ute }\end{array} \\
\end{array}$ & $\begin{array}{l}\text { (1nches) } \\
60 \text { min- } \\
\text { ute }\end{array}$ & $\begin{array}{l}\text { Runoff } \\
\text { (inches) }\end{array}$ & $\begin{array}{l}\text { Ratto of } \\
\text { runoff to } \\
\text { rainfall }\end{array}$ & $\begin{array}{l}\text { Maximum } \\
\text { discharge } \\
\text { (cubic feet } \\
\text { per second) }\end{array}$ \\
\hline \multicolumn{9}{|c|}{$\begin{array}{l}08159165 \text { Big Sandy Creek near McDade } \\
\text { (Drainage area--38.7 square miles) }\end{array}$} \\
\hline $\begin{array}{l}\text { March 27, } \\
\quad 1980\end{array}$ & 14 & 3.26 & 0.30 & 0.54 & 1.04 & 0.49 & 0.15 & 989 \\
\hline $\begin{array}{c}\text { May 13-14, } \\
1980\end{array}$ & 42 & 2.58 & .49 & .71 & .98 & .66 & .26 & 984 \\
\hline $\begin{array}{c}\text { June } 11-14 \text {, } \\
1981\end{array}$ & 88 & 6.57 & .93 & 1.67 & 2.71 & 2.79 & .42 & 4,410 \\
\hline \multicolumn{9}{|c|}{$\begin{array}{l}08159170 \text { Big Sandy Creek near Elgin } \\
\text { (Drainage area }-63.8 \text { square miles) }\end{array}$} \\
\hline $\begin{array}{c}\text { March 27, } \\
1980\end{array}$ & 13 & 3.05 & .41 & .73 & 1.13 & .43 & .14 & 1,340 \\
\hline $\begin{array}{c}\text { May 13-14, } \\
1980\end{array}$ & 40 & 2.85 & .71 & 1.08 & 1.15 & .74 & .26 & 1,720 \\
\hline June $11-14$ & 88 & 8.13 & 1.35 & 2.51 & 3.76 & 2.53 & .31 & 5,760 \\
\hline \multicolumn{9}{|c|}{$\begin{array}{l}08159180 \text { Dogwood Creek near McDade } \\
\text { (Drainage area-- } 0.53 \text { square mile) }\end{array}$} \\
\hline May 13-14, & 18 & 3.33 & .85 & 1.35 & 1.57 & .83 & .25 & 54 \\
\hline \multicolumn{9}{|c|}{$\begin{array}{c}08159185 \text { Dogwood Creek at State Highway } 95 \text { near McDade } \\
\text { (Drainage area--5.03 square miles) }\end{array}$} \\
\hline $\begin{array}{l}\text { May 13-14, } \\
1980\end{array}$ & 40 & 4.72 & .85 & 1.35 & 1.57 & .50 & .11 & 130 \\
\hline
\end{tabular}


The streamflow stations on Big Sandy Creek are located immediately upstream and downstream from the proposed lignite-mining area. The surface runoff from the intervening area between the two gaging stations was computed by subtracting the streamflow occurring at the upstream gage from the streamflow occurring at the downstream gage. Runoff values for the intervening area are presented in table 5.0-2.

For the 3 years ending in September 1982, surface runoff accounted for only 6 inches of the 99 inches of precipitation occurring in the area; thus about 93 inches was absorbed within the watershed or was lost by evapotranspiration.

The effect of antecedent rainfall on runoff is exemplified by the analysis of storms for the drainage area of Big Sandy Creek near McDade. During the storm on March 27 and May 13-14, 1980, total rainfall for

this drainage was 3.26 and 2.58 inches, respectively. Although differences in incremental rainfall during the storms were insignificant (table 5.0-1), the runoff produced by the storm on March 27 was significantly less than runoff produced by the storm on May 13-14. The storm on March 27 produced a total runoff of 0.49 inch (15 percent of the total rainfall), whereas the storm on May 13-14 produced a total runoff of 0.66 inch (26 percent of the total rainfal1). Most of this difference in total runoff is attributed to antecedent rainfall. Total rainfall during the 2 weeks before the March storm was only about 0.4 inch. However, total rainfall during the 2 weeks before the May storm was about 2.7 inches, about 0.8 inch of which occurred on the day before the storm. The effects of antecedent rainfali on runoff as exemplified by these storms are typical for other storms in the drainage area of Big Sandy Creek.

Table 5.0-2.--Rainfall and runoff data, for the intervening area between the two streamflow gages on Big Sandy Creek

\begin{tabular}{ccccc}
\hline Water year & \multicolumn{2}{c}{ Runoff } & $\begin{array}{c}\text { Rainfall } \\
\text { (inches) }\end{array}$ & Ratio of runoff to rainfall \\
\cline { 2 - 5 } 1980 & 2,080 & 1.55 & 31.21 & 0.05 \\
1981 & 3,520 & 2.63 & 40.88 & .06 \\
1982 & 2,640 & 1.97 & a/27.00 & .07 \\
\hline Totals & 8,240 & 6.15 & 99.09 & 0.06 \\
\hline
\end{tabular}

a/ Rain gages inoperative during 0 ctober and November; annual total estimated. 
6.0 GROUND-WATER HYDROLOGY

6.1 Source, Recharge, and Movement of Ground Water

INFILTRATION OF PRECIPITATION RECHARGES THE AQUIFERS IN THE CAMP SWIFT AREA

The Calvert Bluff and Simsboro Formations receive direct recharge at their outcrops. The movement of ground water generally is to the southeast.

The source of ground water in the Camp Swift area is precipitation. Part of the precipitation returns to the atmosphere through evaporation and transpiration, part flows into streams as runoff, and part infiltrates through the soils and rocks to the zone of saturation. Definitions for selected ground-water terms are given in section 10.1 .

Recharge to the Calvert Bluff and Simsboro Formations primarily is by $d_{1}$, ect infiltration of precipitation into the outcrops of these formations. Recharge also may result from infiltration of streamflow from the streams that flow over the outcrop of the aquifers. Where the water table is below the water level in the stream, such as the case with Dogwood Creek, water percolates through the stream channel and into the aquifer. The rate of this percolation depends on the permeability of the material below the stream channel.

Leakage from one aquifer to another through confining beds also is a source of recharge to some aquifers in the Camp Swift area. Water in the Calvert Bluff recharges the underlying Simsboro chiefly by leakage through the lignite and beds of clay, silt, or fine sand near the base of the Calvert Bluff. This interformational recharge is slow because of the small vertical hydraulic conductivity of these confining beds. The driving force is the different hydraulic pressure in the two formations on opposite sides of these beds, with the greater hydraulic pressure being in the Calvert Bluff and the lesser pressure in the Simsboro. The generalized source, recharge, and movement of ground water in the Camp Swift area are shown in figure 6.1-1. 


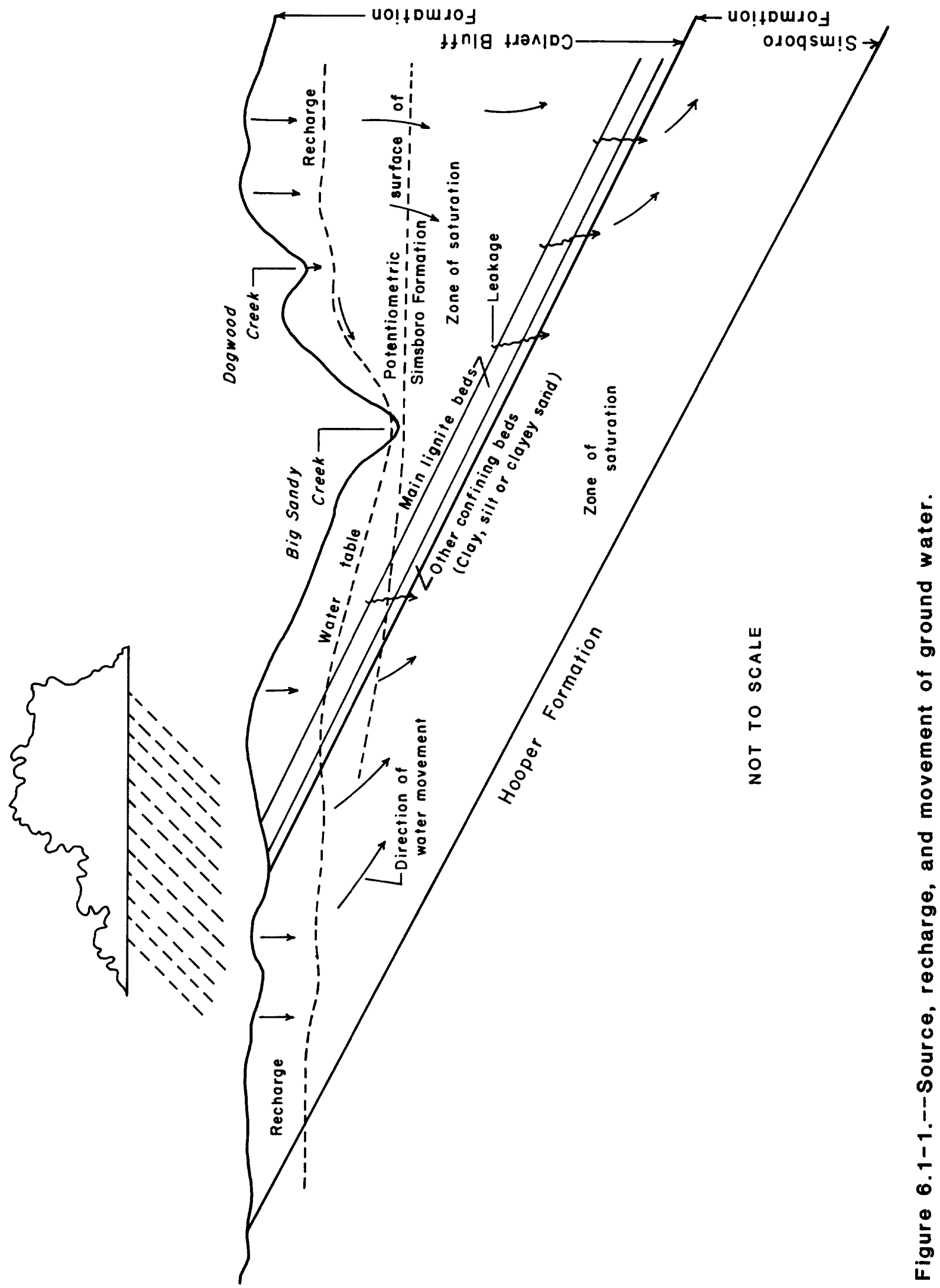




\subsection{Source, Recharge, and Movement of Ground Water--Cont inued}

Ground water moves in the Camp Swift area from the areas of recharge such as the outcrops of the Calvert Bluff, Simsboro, and Hooper Formations to areas of discharge such as deeply incised streams, well fields, and places where interformational leakage can occur. The rate at which the water moves probably varies from less than 10 feet per year in some places to several tens of feet per year in other places, and depends predominantly on porosity, hydraulic coriductivity, and the hydraulic gradient of the aquifer. The unconsolidated sand beds in the Calvert Bluff, Simsboro, and Hooper Formations commonly have different hydraulic conductivities but are much more permeable than the clay, silt, well-cemented sandstone, and lignite beds in some of these formations.

The regional direction of movement of the ground water is to the southeast, but physical features alter the direction locally. In order to understand the local components of movement, the Calvert Bluff and Simsboro Formations need to be considered individually.

Water in the Calvert Bluff travels mainly through channel-sand de- posits and upper-deltaic sand beds. The orientation of most of these channels and the hydraulic gradient is from northwest to southeast, which gives the water deep within the zone of saturation its doininant southeasterly movement. However, ground water at or near the water table at the top of the zone of saturation moves under the effect of gravity and the topography. A water-table map of the Calvert Bluff and adjacent formations, which illustrates the multidirectional movement of the shallow ground water is shown in figure 6.1-2. The shallow water moves in the direction of decreasing altitude of the water table and, for the most part, in the direction of decreasing altitude of the land surface.

Within the Camp Swift Military Reservation shallow-water movement is toward Big Sandy and Dogwood Creeks. A shallow ground-water divide occurs along the southeastern boundary of the reservation (along Farmi-to-ilarket Road 2336 where a land-surface divide also occurs). Shallow water moves southeasterly from this divide toward Piney Creek and northwesterly from this divide toward Big Sandy and Dogwood Creeks. 


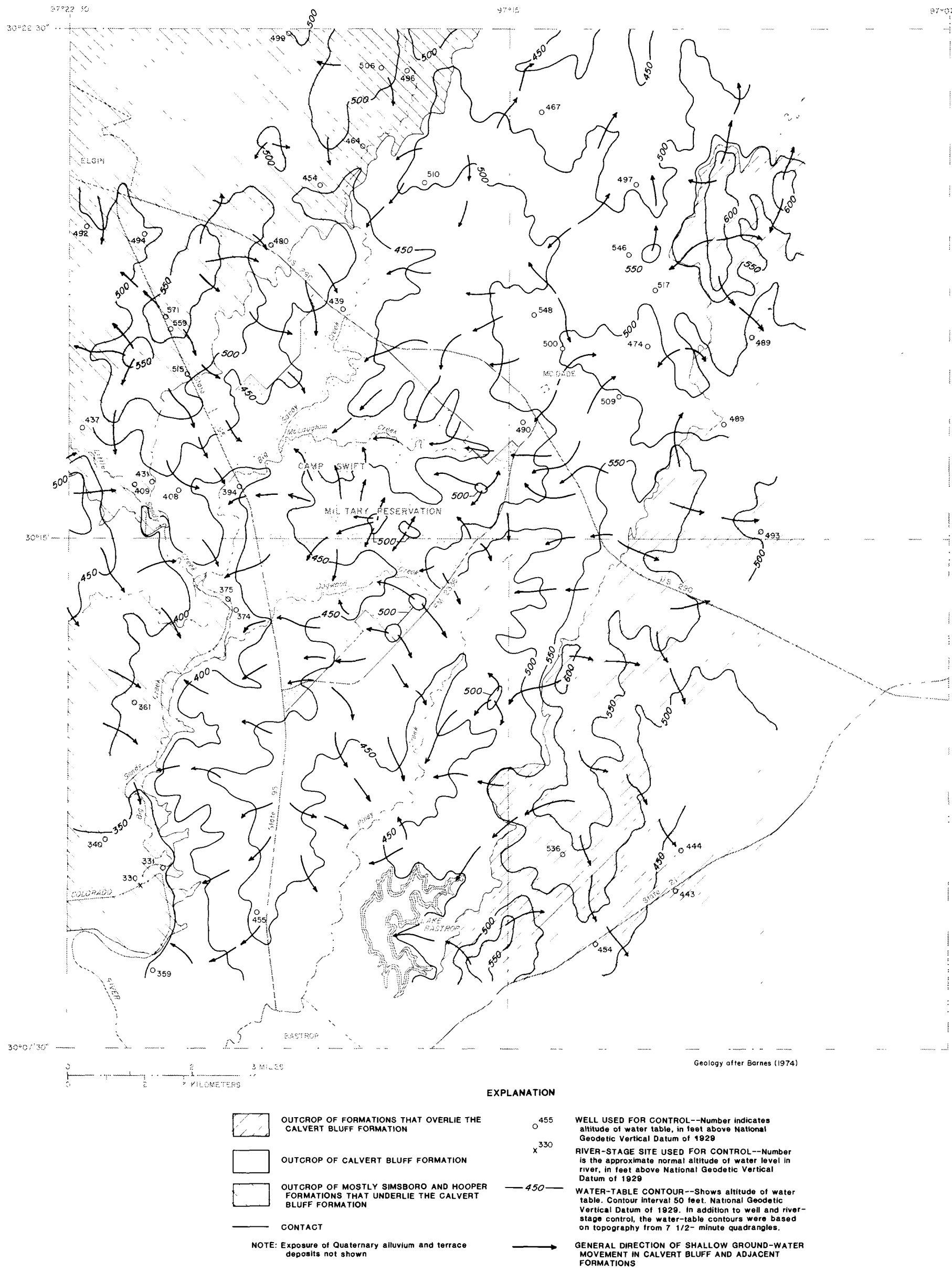

Figure 6.1-2.--Altitude of the water table in the Calvert Bluff and adjacent formations. 


\subsection{Source, Recharge, and Movement of Ground Water--Cont inued}

Vertical water movement from the Calvert Bluff to the Simsboro occurs as leakage through the confining beds near the base of the Calvert Bluff. This process constitutes a natural means of water discharge from the Calvert Bluff and a source of recharge to the Simsboro.

Regional ground-water movement in the Simsboro also is to the southeast. A potentiometric-surface map of the Simsboro, which shows the altitude to which water levels in relatively deep wells in the simsboro will rise is shown in figure 6.1-3. An analysis of the map indicates that ground water deep within the zone of saturation in the Simsboro is moving from the outcrop of the Simsboro in southeasterly and southerly directions. Localized, but extensive pumping has caused cones of depression east of Elgin and especially near the south corner of the Camp Swift Military Reservation. Some of the Simsboro water moves into these depressions from virtually all directions. 


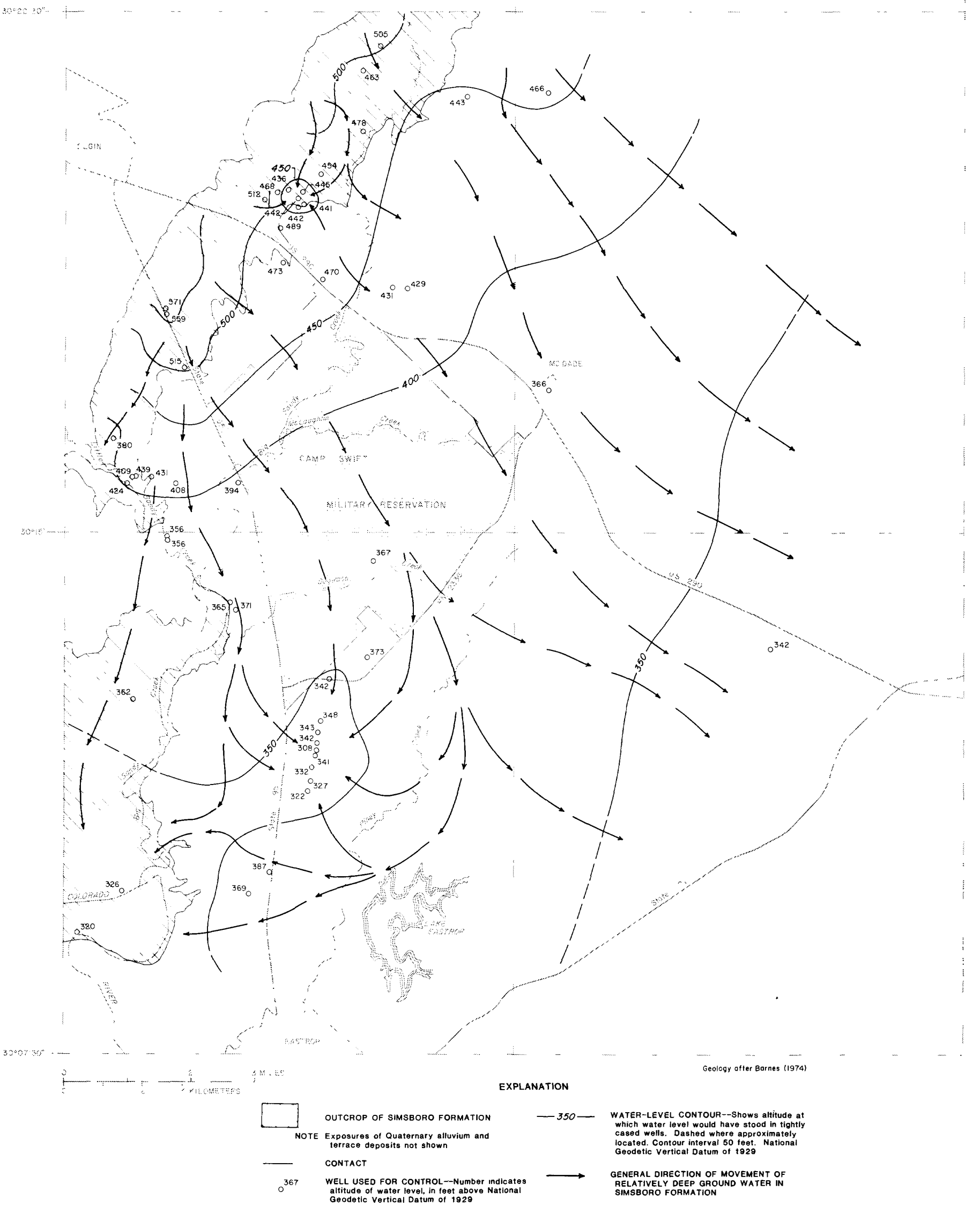

Figure 6.1-3.--Altitude of water levels in wells completed in the Simsboro Formation. 


\title{
6.2 Aquifer Testing
}

\section{U.S. GEOLOGICAL SURVEY PERFORMS GEOHYDROLOGIC TESTING IN CAMP SWIFT}

\author{
Three exploratory holes were drilled in Camp Swift and \\ extensive aquifer tests on nearby city of Bastrop wells were \\ utilized to determine the geohydrologic characteristics \\ of the Calvert Bluff and Simsboro Formations.
}

Because the principal source of ground-water for communities in the Camp Swift study area is the Simsboro Formation and because the lignite is included in the Calvert Bluff Formation, the U.S. Geological Survey drilled three test holes (fig. 4.1-1) in the Camp Swift Military Reservation to determine selected geologic and hydrologic properties of these formations. This information will be useful to companies and individuals that are involved in evaluating the area for environmental reasons and for lignite mining.

The three test holes that were drilled are near the southeast boundary of Camp Swift where the lignite seams in the proposed lease area are relatively deep. The test holes, which are designated $\mathrm{C}-11, \mathrm{C}-12$, and $\mathrm{C}-13$ are spaced 50 feet apart (fig. 6.2-1). Well C-11 is 500 feet deep and is screened in the Simsboro Formation from 240 to 490 feet below 1 and surface. Wells $\mathrm{C}-12$ and $\mathrm{C}-13$ are 220 and 330 feet deep, respectively. We11 C-12 is screened in the Calvert Bluff Formation from 200 to 220 feet below 1 and surface, whereas well $\mathrm{C}-13$ is screened in the Simsboro from 250 to 330 feet.

We11 C-11, with the pump set at a depth of 205 feet below 1 and surface, was test pumped for 48 hours at an average rate of 110 gallons per minute. The water levels in all three wells were monitored for 48 hours during pumping to determine drawdown and for an additional 48 hours after pumping stopped to determine recovery. The maximum drawdown at we11 C-11 was about 94 feet, which translates into a specific capacity of 1.2 gallons per minute per foot of drawdown. This drawdown is considered to be excessive in relation to the pumping rate and is not considered be to representative of the Simsboro. The probable cause of the abnormal specific capacity is incomplete well-development, which resulted in fine sand, silt, and mud clogging much of the screen. The maximum drawdown at well $\mathrm{C}-13$ which is 100 feet from $C-11$, was 1.4 feet.

The water level in well C-12, screened near the base of Calvert Bluff but above the basal confining layers including the two basal 1ignite beds, showed no appreciable change during and after the test pumping of the Simsboro well. This lack of change in the water level demonstrates that the lignite and other tight beds of fine sand or clay are effective confining beds to the Simsboro aquifer and that hydraulic connection between the Calvert Bluff and Simsboro is restricted. This situation of restricted hydraulic connection probably predominates throughout most of the area, except in places where the lignite and other tight beds are discontinuous. In such areas, water from the Calvert Bluff could move more easily into the Simsboro. 


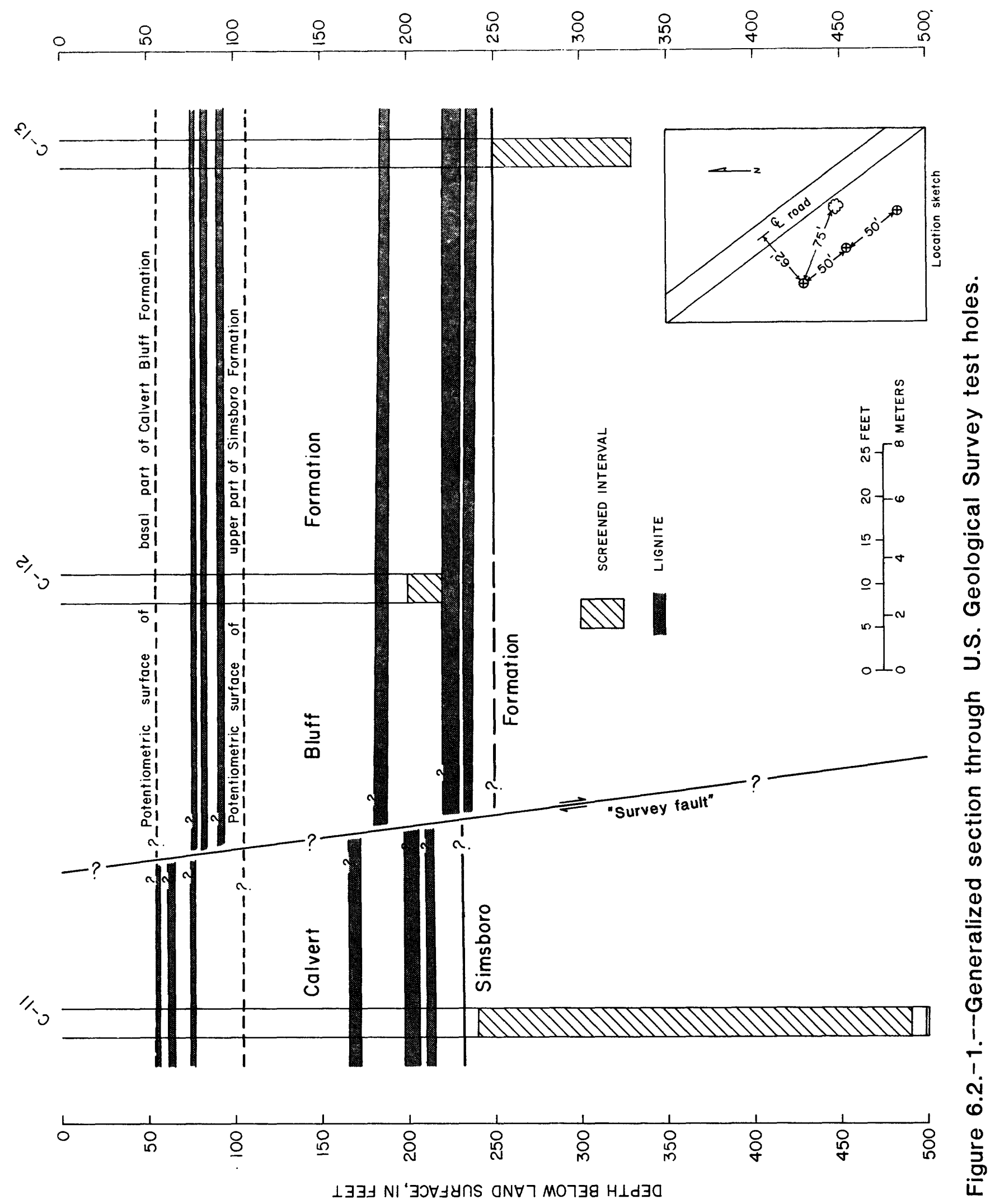




\subsection{Aquifer Testing--Continued}

The hydraulic properties of the Simsboro aquifer were derived from aquifer tests of several city of Bastrop municipal wells (formerly public-supply wells for the Camp Swift Military Reservation). The well field is located from 0.75 to 1.5 miles south of the south corner of Camp Swift (fig. 4.1-1). Because of this close proximity of the well field to the Camp Swift Military Reservation, the hydraulic properties of the Simsboro in the two areas should be similar.

Results of extensive aquifer testing of the Simsboro involving several wells (Guyton, 1942) are presented in section 10.6. The transmissivities and storage coefficients obtained from the tests were derived by the application of the Theis nonequilibrium formula and by the Thiem formula for artesian conditions. As a basis for computation, it is assumed from the data in section 10.6 that a transmissivity of 6,000 feet squared per day and a storage coefficient of 0.0004 may be considered to be average values. Specific capacities for six wells after 1.5 hours of pumping ranged from 9.5 to 21 gallons per minute per foot and averaged 17 gallons per minute per foot.

These average values of transmissivity and storage coefficient were used in the Theis nonequilibrium formula to prepare the curves in figure 6.2-2. The curves show the theoretical drawdown in water levels at vari- ous distances from a center of pumping at the rate of 1,000 gallons per minute after 1 month, 3 months, 6 months, and 1 year of continuous pumping. The theoretical drawdown is proportional to the pumping rate. For example, to compute the drawdown produced by pumping 500 and 5,000 gallons per minute, the drawdown indicated in the diagram should be multiplied by 0.5 and 5.0 , respectively.

Inherent in the mathematical formulas from which the theoretical drawdown curves depicted in figure 6.2-2 were derived are several idealistic assumptions, among which that the aquifer is lithologically homogeneous and isotropic and is infinite in areal extent. Because these conditions are unrealistic in the case of the Simsboro, the values of drawdown are necessarily subject to varying degrees of error.

The presence of the Simsboro outcrop, which is from 1 to 7 miles west of Camp Swift, is a chief factor that affects the theoretical drawdown values. The outcrop is a recharge boundary that will have a mitigating effect on water-level drawdowns, in which case the actual drawdowns will be somewhat less than the theoretical curves show. Faults, in contrast, which usually are barriers to groundwater flow, could increase the theoretical drawdowns. Computer models of ground-water flow need to be considered if more precise effects of pumping are needed. 


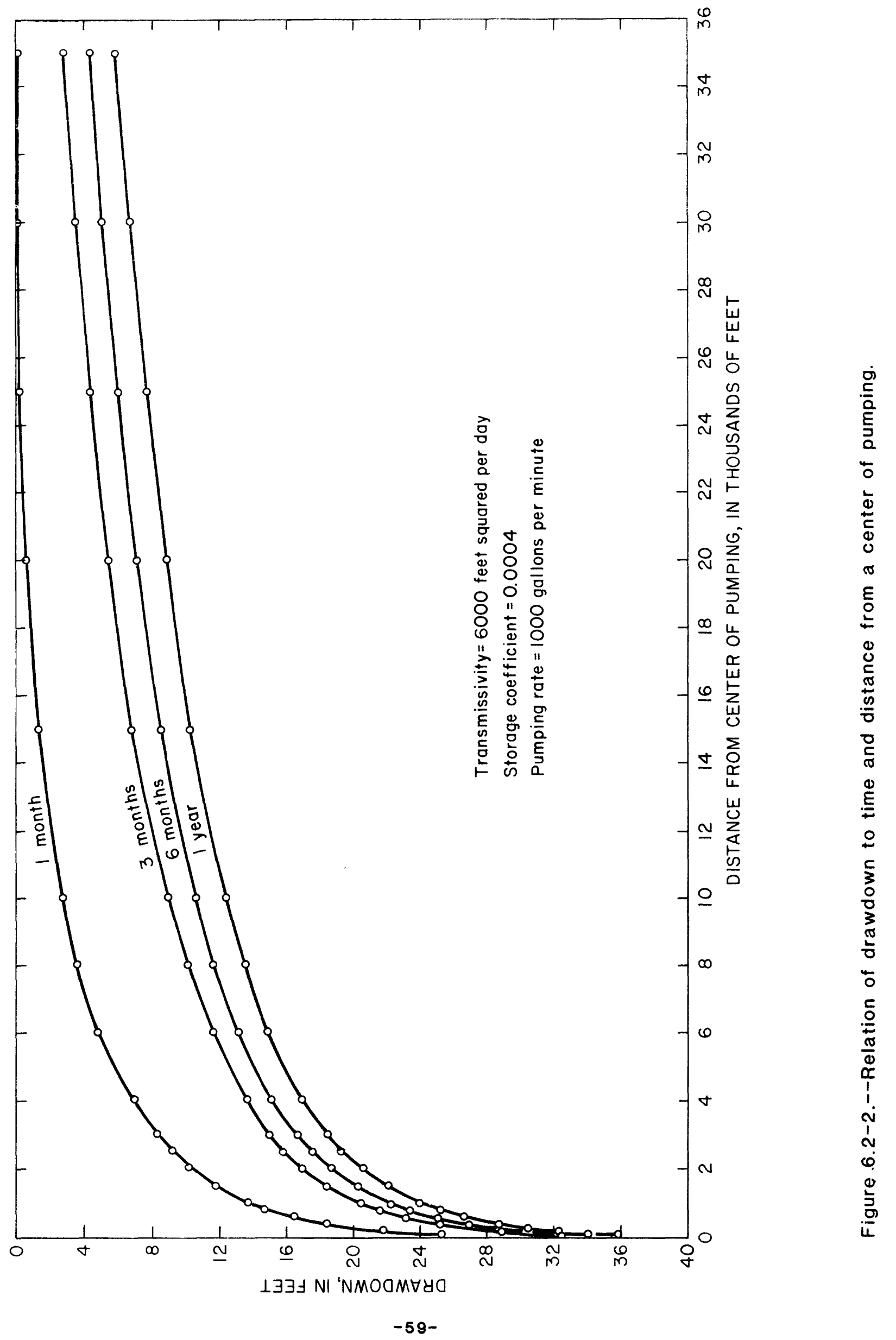




\title{
7.0 WATER QUALITY
}

\subsection{Surface-Water Quality}

SURFACE-WATER SAMPLES WERE ANALYZED TO DEFINE PREMINING QUALITY

\author{
Water Samples were Collected During Different Seasons \\ and During Different Flow Conditions to Depict \\ the Variance in Quality
}

The concentrations and types of solutes dissolved in surface water that drains from areas where municipal and industrial effects are minimal principally depend on the chemical composition and physical structure of the rocks and soils contacted by the water and on the duration of the contact. The quantity of the soluble material in rocks and soils available for solution is decreased by leaching. Consequently, the rocks and soils near land surface in humid areas usually are well leached, and storm runoff from these areas usually contains small concentrations of most dissolved solutes. However, in headwater regions where much of the runoff in ephemeral streams result from flash floods, both the quantity and quality of the water may vary widely. During periods of sustained low or base flow, the water in many streams consists mostly of inflow of ground water, and the concentrations of most solutes are maximum. The concentrations usually decrease significantiy during and after periods of storm runoff. However, some streams do not have this simple pattern because of other factors that affect the solute concentrations. Definitions of selected water-quality-related terms are given in section 11-3.

As part of this study to obtain background hydrologic data for the Camp Swift area prior to lignite mining, automatic water samplers were installed at the four streamflow stations. (See figure 4.2-1). These samplers were activated at a pred- etermined stage and collected discrete water samples at predetermined time intervals. Automatic sampling during some periods was supplemented by manual sampling. Selected samples collected during storm runoff were analyzed for a variety of constituents or properties including major dissolved inorganic constituents, selected dissolved trace constituents, total nutrients, total pesticides, and indicator bacteria. The results of these analyses are given in section 10.3 .

The quality of surface water in the Camp Swift area generally is suitable for most uses, but varies significantly in response to variations in discharge and related factors. Low flows in Big Sandy Creek are sustained principally by the inflow of shallow ground water. During these periods, concentrations of major dissolved inorganic constituents in streamflow are large. During the early stages of storm runoff, the concentrations of the major constituents al so are large due to the leaching of soluble weathered materia? that has accumulated at the land surface since the last storm. As the duration of the stormi runoff cuntinues and the soluble material is flushed from the land surface, the concentrations of the major dissolved constituents decrease. This "first flush" pattern also is typicai for indicator bacteria. However, concentrations of some of the other constituents such as total nitrogen speries and total phosphorus do not have the typical 


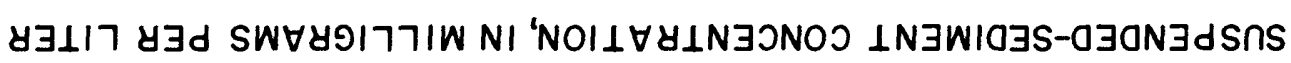

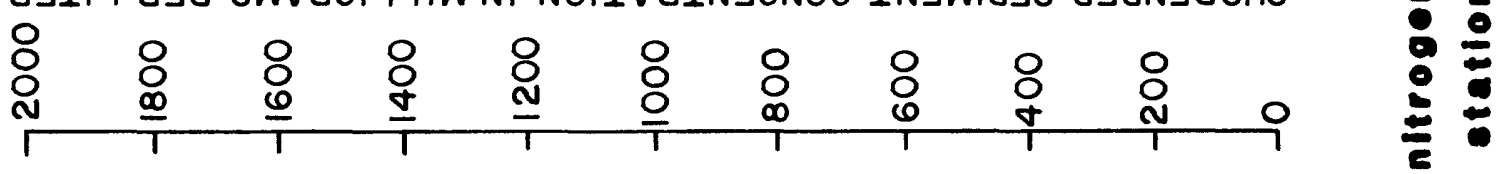

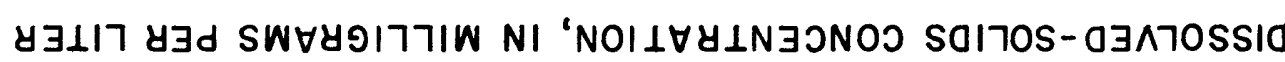
응

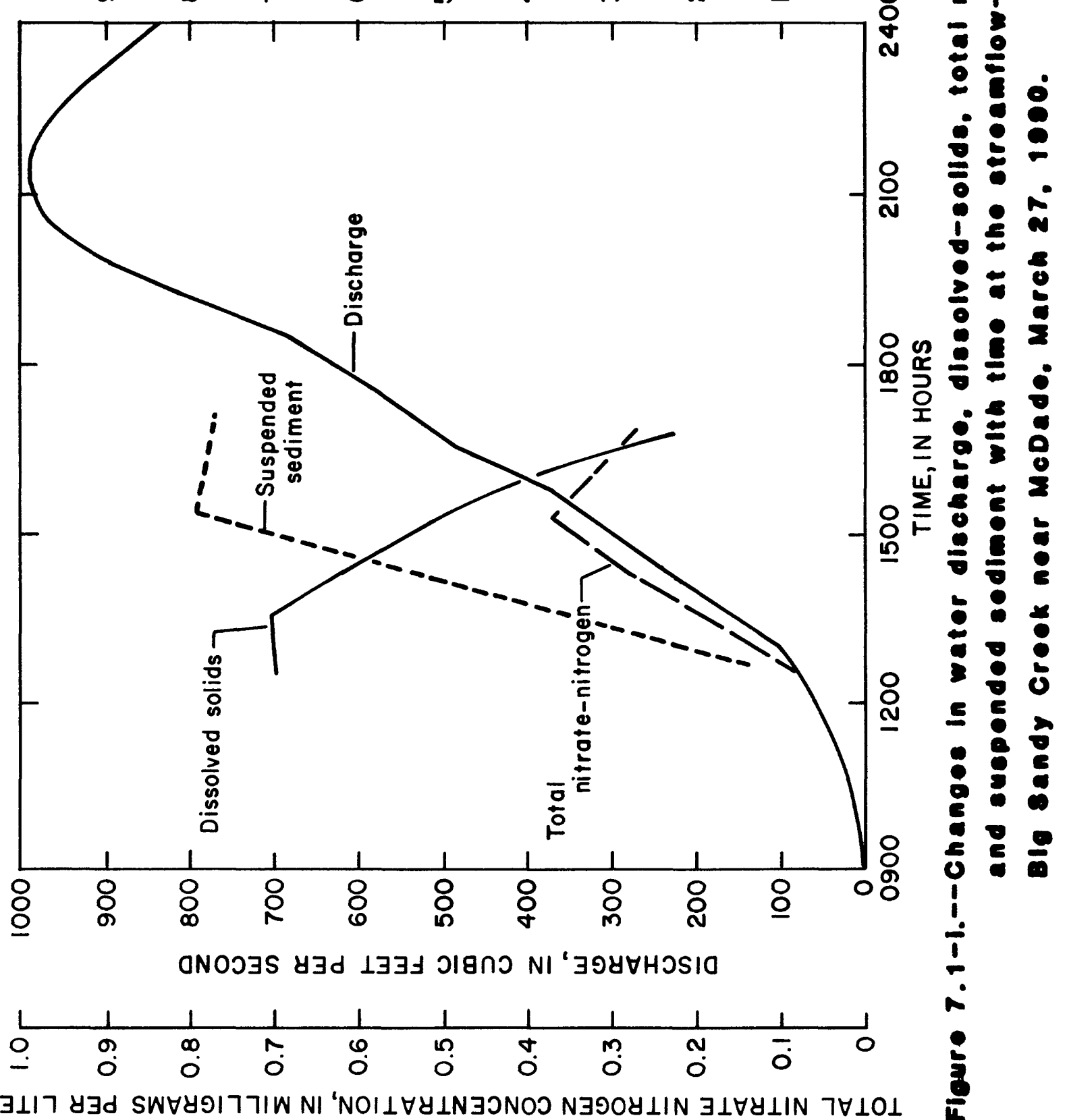




\title{
7.0 WATER QUALITY--Continued
}

\subsection{Stream Sediment}

\section{LARGE SEDIMENT YIELDS MAY RESULT FROM SURFACE MINING}

\author{
Suspended sediments in the lignite mining area are predominantly clay
}

Sediment yields are affected by numerous factors including physiography, soils, climate, and land use. Land-use activities such as forest clearing, cultivation, road construction, and surface mining may drastically increase natural erosion and sediment yields. During surface mining, large volumes of exposed unconsolidated spoil may be a major source of sediment. Definitions for sediment-related terms are given in section 11.4.

Suspended-sediment samples were collected by automated samplers and manually at three sites in the proposed mining area. Locations of the three sampling sites, 08159165 Big Sandy Creek near McDade; 08159170 Big Sandy Creek near Elgin; and 08159180 Dogwood Creek near McDade, are shown in figure 4.2-1. The results of suspended-sediment analyses for samples from these streams are presented in section 10.3. Continuous streamflow records are available for two of the sites, Big Sandy Creek near McDade and Big Sandy Creek near Elgin. The relation of stream discharge to suspended sediment is shown in figure 7.2-1; and particle-size distribution of the suspended sediment is shown in figure 7.2-2.
According to the U.S. Soil Conservation Service (1959) this area should yield approximately 0.54 acrefoot of sediment per square mile per year. The sediment yield during the short duration of this study was significantly smaller; but surface mining could greatly increase this yield.

\section{Big Sandy Creek near McDade}

Seventeen samples for the analysis of suspended-sediment concentrations were collected from Big Sandy Creek near McDade during the period of investigation. Most of the samples were collected during two floods in March and May 1980. The suspended-sediment concentrations ranged from 6 milligrams per liter during low flow to 2,680 milligrams per liter during flood runoff. The instantaneous suspended-sediment discharge ranged from virtually zero during low flow to 3,260 tons per day during flood runoff. The relation of instantaneous suspended-sediment discharge to water discharge is shown in figure 7.2-1a. These data and streamflow records indicate a sediment yield of about 0.1 acre-foot per square mile per year. 
A. 08159165 BIG SANDY CREEK

NEAR MC DADE

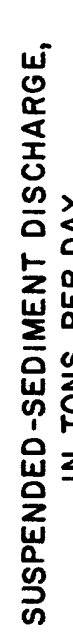

B. 08159170 BIG SANDY CREEK NEAR ELGIN
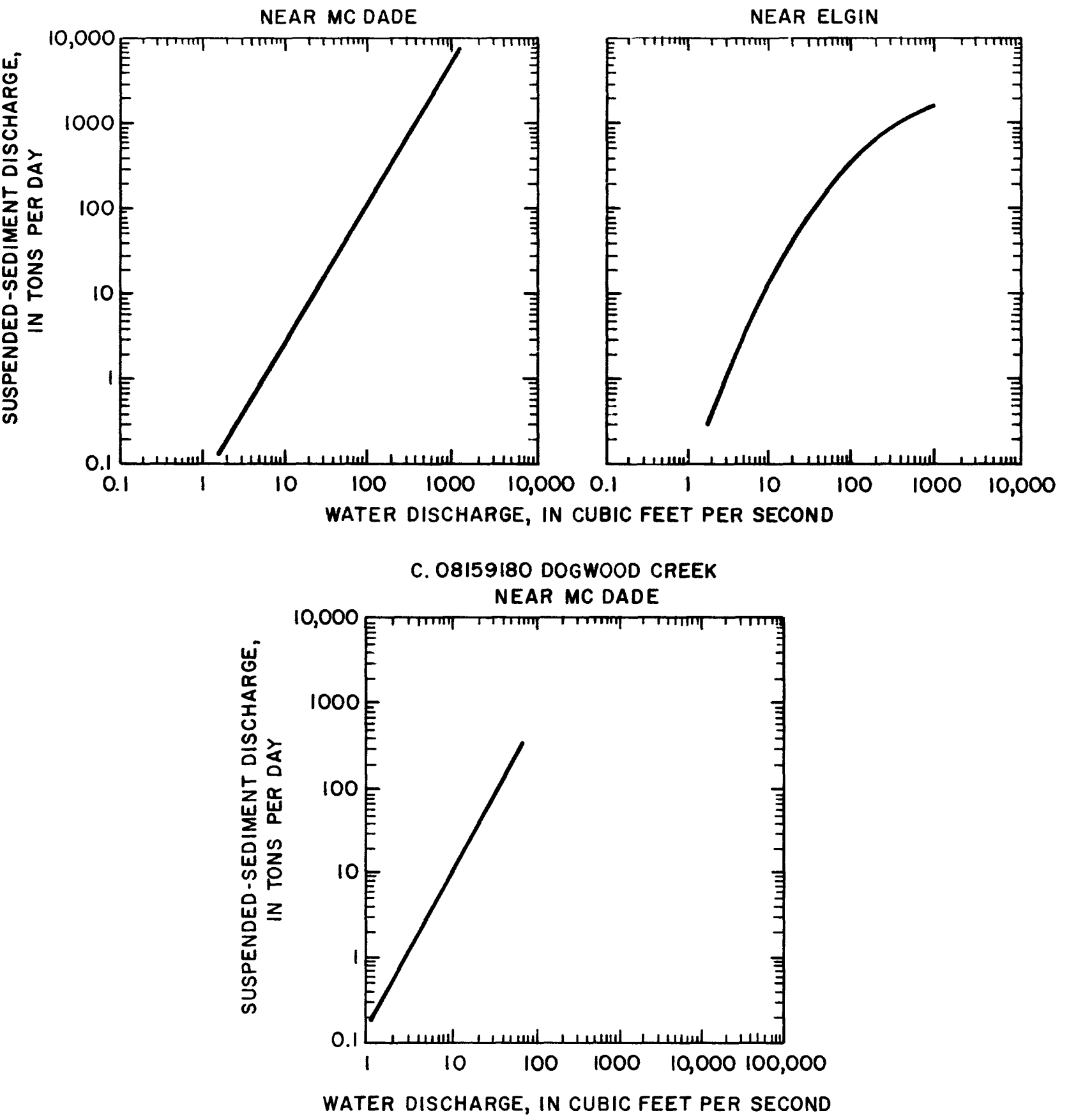

Figure 7.2-1.--Relationship between stream discharge and suspended sediment. 


\subsection{Stream Sediment--Continued}

The particle-size distribution of seven samples was determined, and the discharge-weighted averages of the sizes were computed. These data, which are shown in figure 7.2.-2a, indicate that the suspended sediments at this station is composed of about 10 percent sand, 11 percent silt, and 79 percent clay.

The streambed is well defined, and the banks both upstream and downstream from the station are shallow and densely vegetated. Samples indicated that both the streambed and stream banks are composed mostly of fine-to-medium sand with some gravel and small rocks.

\section{Big Sandy Creek near Elgin}

Twenty-one samples for the analysis of suspended-sediment concentrations were collected from Big Sandy Creek near Elgin during the period from October 1979 to May 1981. Most of these samples were collected during floods in March and May 1980 and May 1981. The suspended-sediment concentrations ranged from $10 \mathrm{milli-}$ grams per liter during low flow to 2,100 milligrams per liter during flood runoff. Instantaneous suspended-sediment discharge ranged from 0.01 ton per day during low flow to 1,670 tons per day during flood runoff. The relation of instantaneous suspended-sediment discharge to water discharge is shown in figure 7.2-1b. These data and streamflow records indicate a sediment yield of about 0.07 acre-foot per square mile per year.

Particle-size distribution of three sediment samples, collected in March and May 1980 at flows between 27 and 178 cubic feet per second was determined, and the discharge-weighted averages of the individual sizes were computed. These data, which are shown in figure $7.2-2 b$, indicate that the suspended sediment is composed of about 14 percent sand, 22 percent silt, and 64 percent clay.

The streambed and banks at this site are similar to those of Big Sandy Creek near McDade. The channel is well defined and the banks are densely vegetated. The bed contains gravel, small rocks, and medium-to-fine sand. The shallow banks are composed of medium-to-fine sand.

\section{Dogwood Creek near McDade}

Ten samples for the analysis of suspended-sediment concentrations were collected from Dogwood Creek near McDade during January, March, and May 1980. The suspended-sediment concentration ranged from 54 to 701 milligrams per liter and instantaneous suspended-sediment discharge ranged from 0.22 to 51 tons per day. The relationship between suspendedsediment discharge and water discharge is shown in figure 7.2-1c. Sediment yield was not computed because the station is not a continuous-record streamflow station.

Selected particle-size distribution was determined for seven samples, but the distribution of silt and clay was determined for only two samples. Suspended sediment in these two samples averaged about 1 percent sand, 7-percent silt, and 92-percent clay (fig. 7.2-2c). The discharge-weighted concentration based on all seven samples consisted of 3 percent sand and 97 percent silt and clay.

The streambed upstream from the site is poorly defined and the banks are densely vegetated with small shrubs and trees. The streambed is composed of hard packed clay. The banks are easily eroded and are composed of clay and sand. 
A. 08159165 BIG SANDY CREEK NEAR MC DADE

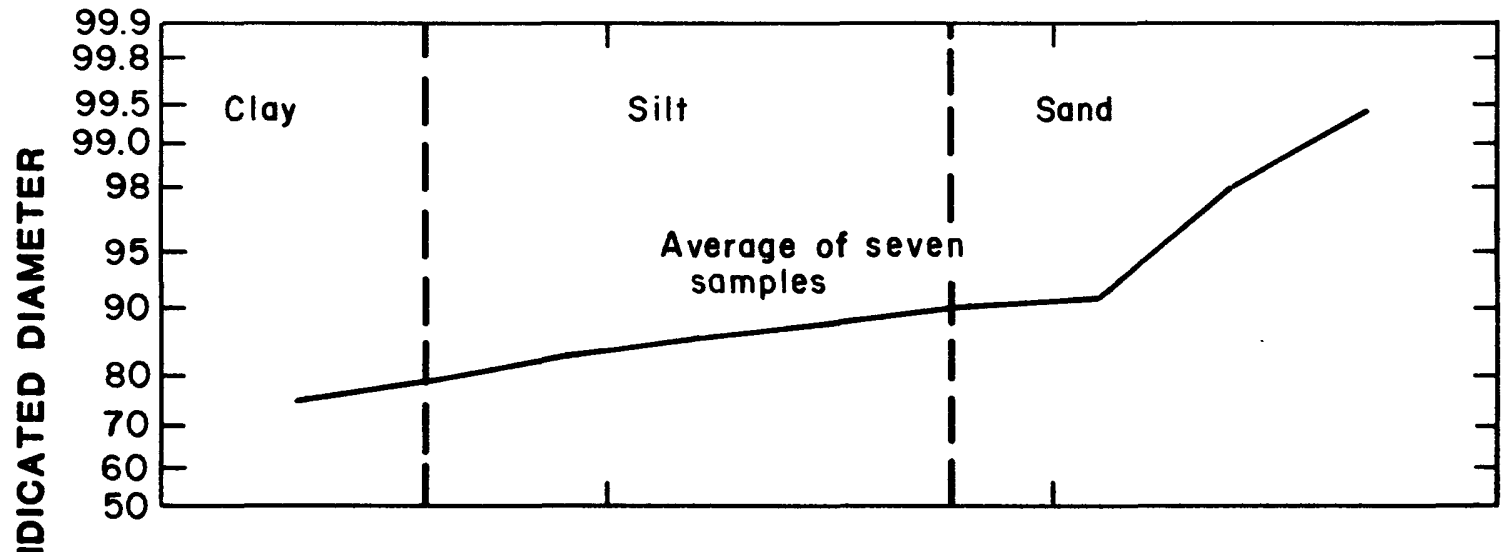

B. 08159170 BIG SANDY CREEK NEAR ELGIN
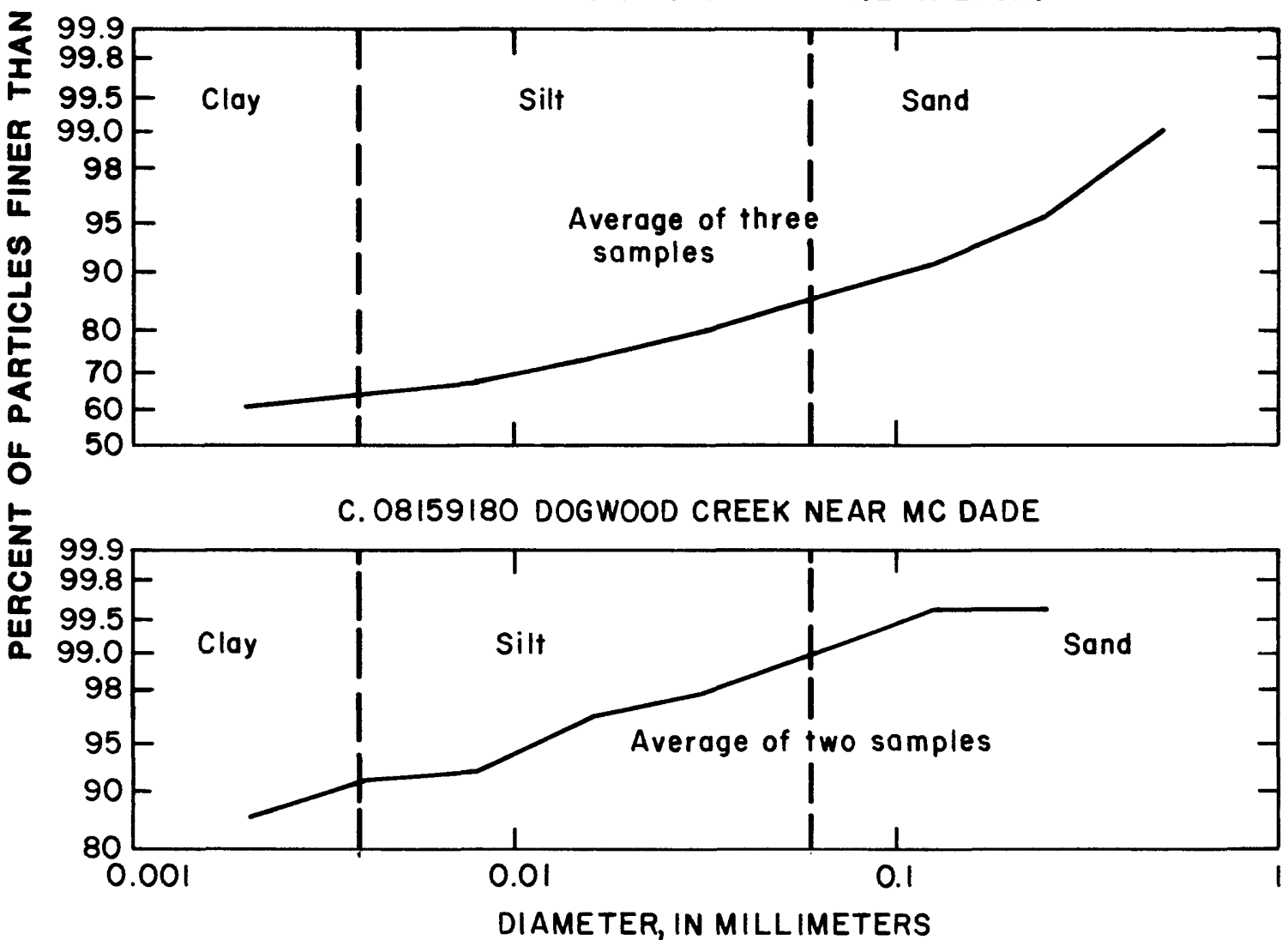

Figure 7.2-2.--Particle-size distribution of suspended sediment. 


\title{
7.0 WATER QUALITY
}

\subsection{Ground-Water Quality}

\author{
GROUND-WATER SAMPLES WERE ANALYZED TO DEFINE PREMINING QUALITY \\ The chemical quality of ground water generally is \\ sui table for most domestic uses with few exceptions
}

\begin{abstract}
Ground water contains dissolved solutes from many sources. The sources and significance of selected constituents and properties commonly reported in water analyses are given in section 10.6. Analyses of water samples from 13 wells in the Camp Swift and surrounding areas included most of these major dissolved inorganic constitutents, selected dissolved trace constituents, total nutrients, and related properties. Analyses of samples from three wells also included selected total pesticides and related organic compounds. The results of these analyses to determine the quality of ground water prior to mining are given in table 7.3-1.
\end{abstract}

The results of the analyses for major inorganic constituents show that chemical composition of the water varies significantly from formation to formation and from place to place within each formation. Analyses of samples from two wells generally indicate that water in the Hooper Formation is a calcium bicarbonate type and very hard.

Analyses of samples from eight wells indicate that the chemical composition of water in the Simsboro Formation varies areally. Water from five wells completed in the Simsboro Formation is a calcium bicarbonate type; water from two wells is a sodium chloride type; and water from one well is a mixed calcium sodium bicarbonate type. The water in most areas of the formation is very hard. 


\begin{tabular}{|c|c|c|c|c|c|}
\hline 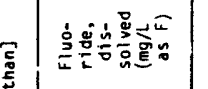 & & & 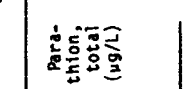 & $\mid$ & \\
\hline 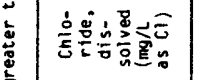 & 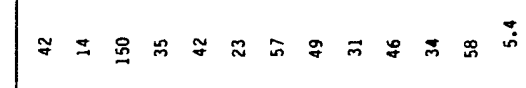 & 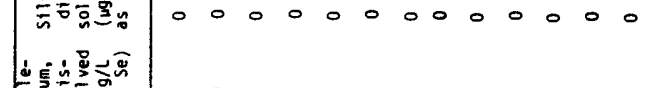 & 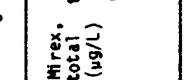 & 竎 3 & \\
\hline & 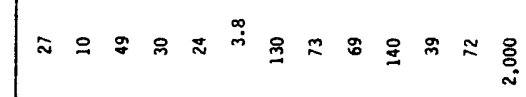 & & 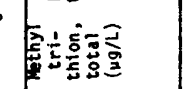 & $\mid \frac{3}{8} \div$ & \\
\hline 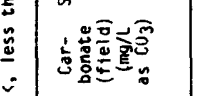 & $\ldots$ & 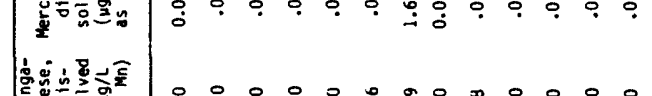 & 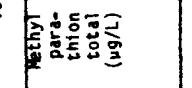 & $\mid \begin{array}{c}8 \\
8\end{array}$ & \\
\hline 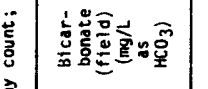 & 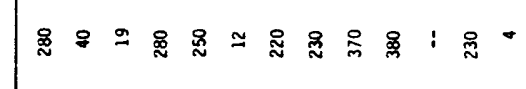 & 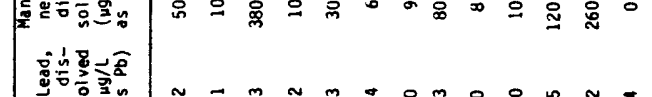 & 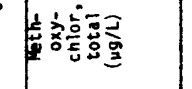 & 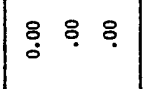 & \\
\hline 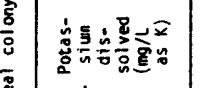 & 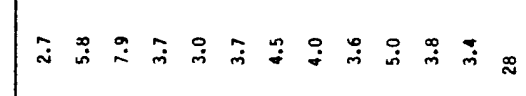 & 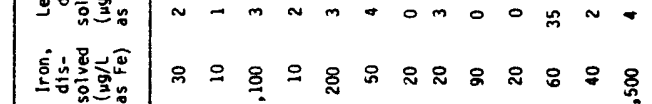 & 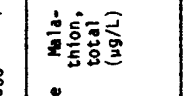 & $\mid \begin{array}{c}8 \\
8 \\
3\end{array}$ & \\
\hline & 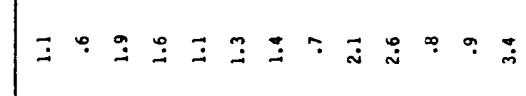 & 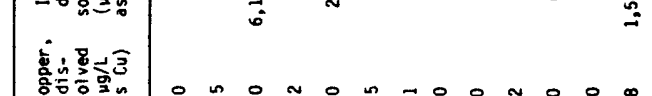 & $a_{10}^{2}$ & $\mid$ & \\
\hline $\begin{array}{l}2 \\
\end{array}$ & 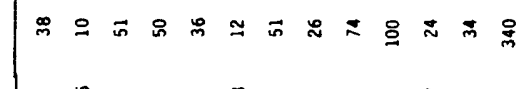 & 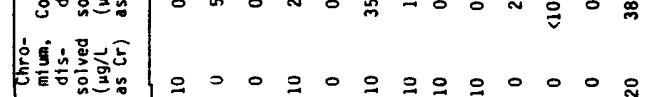 & 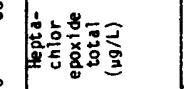 & 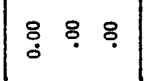 & \\
\hline 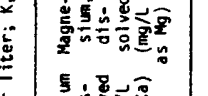 & 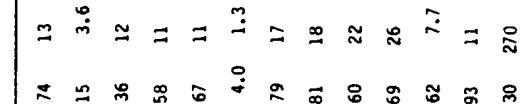 & 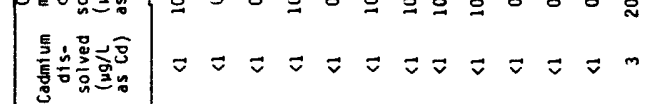 & 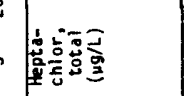 & $\mid 88 \%$ & \\
\hline & $800=808=8$ & $\mid$ & 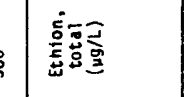 & $\mid \frac{3}{2} \div$ & \\
\hline 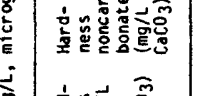 & 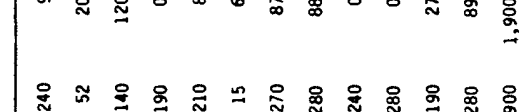 & 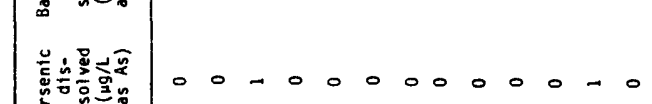 & 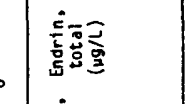 & 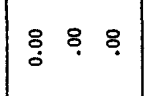 & \\
\hline 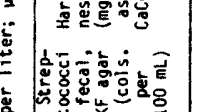 & $\therefore$ & 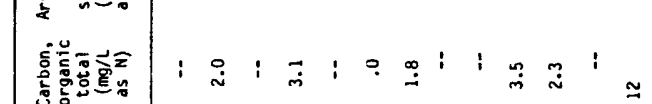 & 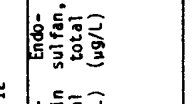 & 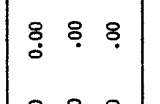 & \\
\hline & $0 \frac{g}{\dot{z}} 0000000000$ & 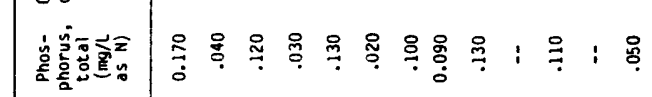 & 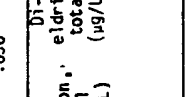 & & $\dot{\phi}$ \\
\hline 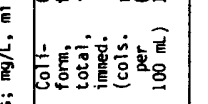 & 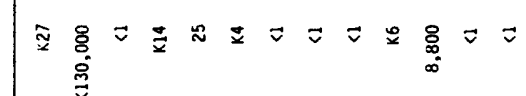 & $\mid$ & 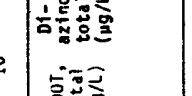 & $\left|\begin{array}{ccc}0 & 0 \\
3 & 8 & 8 \\
3\end{array}\right|$ & \\
\hline & $\mid$ & 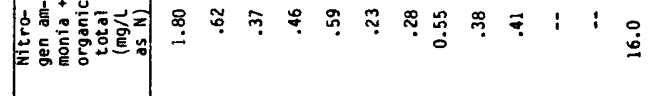 & 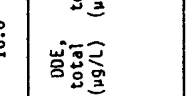 & $\mid \frac{8}{8} 8.8$ & \\
\hline & ะ๐: & 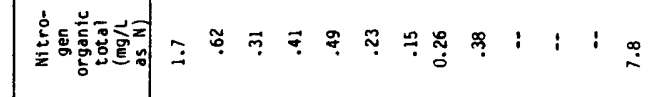 & 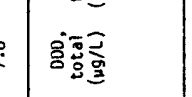 & $\frac{88}{8} 8$ & \\
\hline 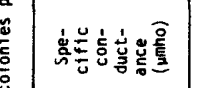 & 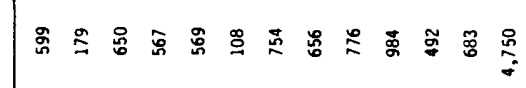 & 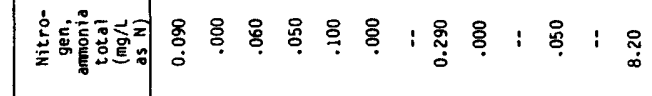 & 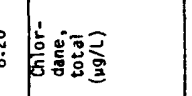 & $\mid \frac{8}{8}:$ & $\begin{array}{llll} & 0\end{array}$ \\
\hline 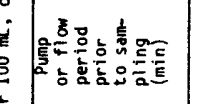 & $2: 8:$ & 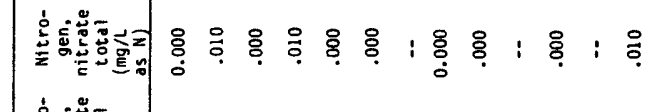 & 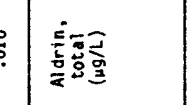 & 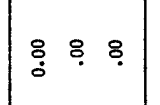 & \\
\hline & 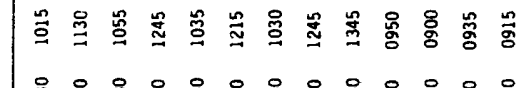 & 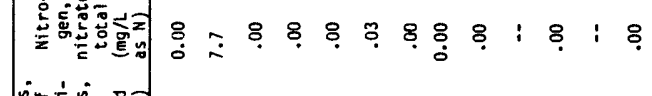 & 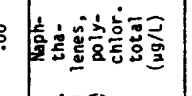 & $\because 8 \div$ & \\
\hline & $\begin{array}{ll}0 \\
0\end{array}$ & 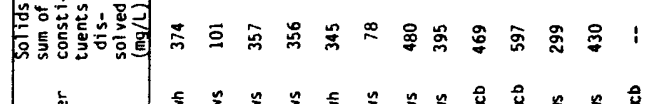 & 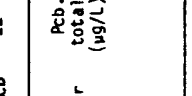 & $\left|\begin{array}{lll}8 & 8 \\
3 & 8 \\
0 & 0\end{array}\right|$ & \\
\hline & | & 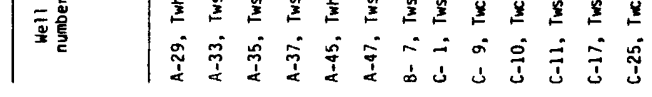 & & & \\
\hline
\end{tabular}


7.3 Ground-Water Qual ity--Cont inued

Analyses of samples from three wells indicate that the chemical composition of water in the Calvert Bluff Formation varies significantly. Water from two wells is a mixed sodium calcium bicarbonate type. Water from the other well is a mixed sulfate type in which no single cation predominated. The water generally is very hard.

Ground water in the Camp Swift area is being used principally for municipal and domestic purposes. Regulations for selected water-quality constituents and properties estab1 ished by the U.S. Environmental Protection Agency (1977a, b) are summarized in table 7.3-2. Based on these regulations, quality of the ground water generally is suitable for most uses. Concentration of dissolved iron in two samples and the concentration of dissolved manganese in four samples exceeded the secondary standards of 300 and 50 micrograms per liter, respectively.

Bacteriological analysis of samples indicate that fecal contamination fron warm-blooded animals or humans is degrading the ground-water quality in some areas. However, such contamination does not appear to be widespread and probably results from the infiltration of wastes into poorly-cased dug wells or incomplete development of recently drilled wells. 
Table 7.3-2.--Summary of regulations for selected water-quality constituents and properties for public water systems

[ $\mu \mathrm{g} / \mathrm{L}$, micrograms per liter; $\mathrm{mg} / \mathrm{L}, \mathrm{milligrams}$ per liter]

DEFINITIONS

Contaminant.--Any physical, chemical, biological, or radiological substance or matter in water.

Public water system.--A system for the provision of piped water to the public for human consumption, if such system has at least 15 service connections or regularly serves at least 25 individuals daily at least 60 days out of the year.

Primary (mandatory) standard.--The maximum permissible level of a contaminant in water that is delivered to the free-flowing outlet of the ultimate user of a public water system. Primary standards are those set by the U.S. Environmental Protection Agency (1977a) in the National Interim Primary Drinking Water Regulations. These regulations deal with contaminants that may have a signicant direct effect on the health of the consumer and are enforceable by the Environmental Protection Agency.

Secondary (recommended) standard. --The recommended permissible concentration of a contaminant in water that is delivered to the free-flowing outlet of the ultimate user of a public water system. Secondary standards are those proposed by the Environmental Protection Agency (1977b) in the National Secondary Drinking Water Regulations. These regulations deal with contaminants that may not have a significant direct effect on the health of the consumer, but their presence in excessive quantities may affect the esthetic qualities and discourage the use of a drinking-water supply by the public.

\section{INORGANIC CHEMICALS AND RELATED PROPERTIES}

Contaminant
Arsenic (As)
Barium (Ba)
Cadmium (Cd)
Chloride (Cl)
Chromium (Cr)
Copper (Cu)
Iron (Fe)
Lead (Pb)
Manganese (Mn)
Mercury ( $\mathrm{Hg}$ )
Nitrate (as N)
pH
Selenium (Se)
Silver (Ag)
Sulfate (SO 4$)$
Zinc ( $\mathrm{Cn}$ )
Dissolved solids

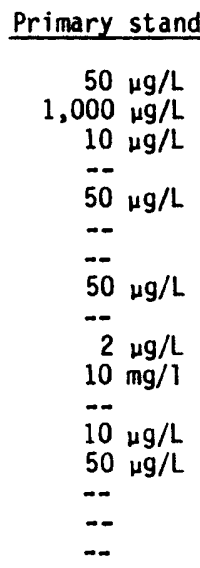

Secondary standard

$$
\begin{aligned}
& - \\
& - \\
& \text {-. } \\
& 250 \mathrm{mg} / \mathrm{L} \\
& \text {-- } \\
& 1,000 \mu \mathrm{g} / \mathrm{L} \\
& 300 \mu \mathrm{g} / \mathrm{L} \\
& 50 \mu \mathrm{g} / \mathrm{L} \\
& - \\
& - \\
& 6.5-8.5 \\
& - \\
& 250 \mathrm{mg} / \mathrm{L} \\
& 5,000 \mu \mathrm{g} / \mathrm{L}
\end{aligned}
$$

Fluoride.--The maximum permissible concentration for fluoride depends on the annual average of the maximum daily air temperatures for the location in which the comunity water system is situated. A range of annual averages of maximum daily air temperatures and corresponding maximum permissible concentration level for fluoride are given in the following tabulation:

$\frac{\text { Average of maximum daily air temperatures }}{\text { (degrees Celsius) }}$

$$
\begin{aligned}
& 12.0 \text { and bel ow } \\
& 12.1-14.6 \\
& 14.7-17.6 \\
& 17.7-21.4 \\
& 21.5-26.2 \\
& 26.3-32.5
\end{aligned}
$$

\begin{tabular}{|c|c|}
\hline Contaminant & $\frac{\text { Primary standard }}{(\mu \mathrm{g} / \mathrm{L})}$ \\
\hline $\begin{array}{l}2,4-D \\
\text { Silvex }\end{array}$ & $\begin{array}{r}100 \\
10\end{array}$ \\
\hline
\end{tabular}

\section{Chlorinated Hydrocarbons}

\section{Contaminant}

$$
\text { Primary standard }
$$$$
(\mu \mathrm{g} / \mathrm{L})
$$

Endrin

Lindane

Methoxychlor

Toxaphene

0.2
4
100
5

ORGANIC CHEMICALS

Primary standard (mg/L)
2.4
2.2
2.0
1.8
1.6
1.4

\section{Chlorophenoxys}




\title{
CHEMICAL ANALYSIS WAS PERFORMED ON CORE SAMPLES
}

\author{
The overburden at Camp Swift was analyzed for major \\ inorganic constituents and trace elements
}

\begin{abstract}
In December 1980 a continuous core was cut through the Calvert Bluff Formation into the upper part of the Simsboro Formation at well C-13. Core was recovered from 168 feet of the interval from the land surface to a depth of 255 feet, except for mainly unconsolidated sand beds. Gamma-gamma (formation density), natural gamma-ray, spontaneouspotential, and resistivity logs were obtained at a depth of 322 feet. The core samples from the overburden were analyzed for major inorganic constituents and trace elements. Core samples from the lignite beds al so were analyc 'd for trace elements, percent moistu-a, percent ash, percent volatile material, percent fixed carbon, percent sulfur, and gross heat of combustion. These analyses were performed by the Southwestern Laboratories, Dallas, Texas, according to guidelines set by the Railroad Commission of Texas, whose authority includes the regulation of the exploration and surface mining of coal in
\end{abstract}

Texas. Results of these analyses are shown in section 10.7. The results of the analyses for selected constituents also are shown in figure 8.0-1 to relate the chemical composition of the material to lithology, geophysical response, and depth.

The overburden consists of stacked packages of sand, silt, clay, and lignite (fig. 8.0-1). The recovered sand was very fine to fine and generally was well sorted. Most of the 87 feet of the section where core was not recovered occurred in unconsolidated coarse sand. Carbonaceous streaks, leaf impressions, and vertical burrows were observed in the finer-grained silts and clays. Thin "hard streaks" of sandstone with hematitic staining were infrequently present. Both the "hard streaks" and the lignite have high resistivity and negative spontaneous potential, but the gamma-gamma log can be used to distinguish the dense sandstone from the less dense lignite. 


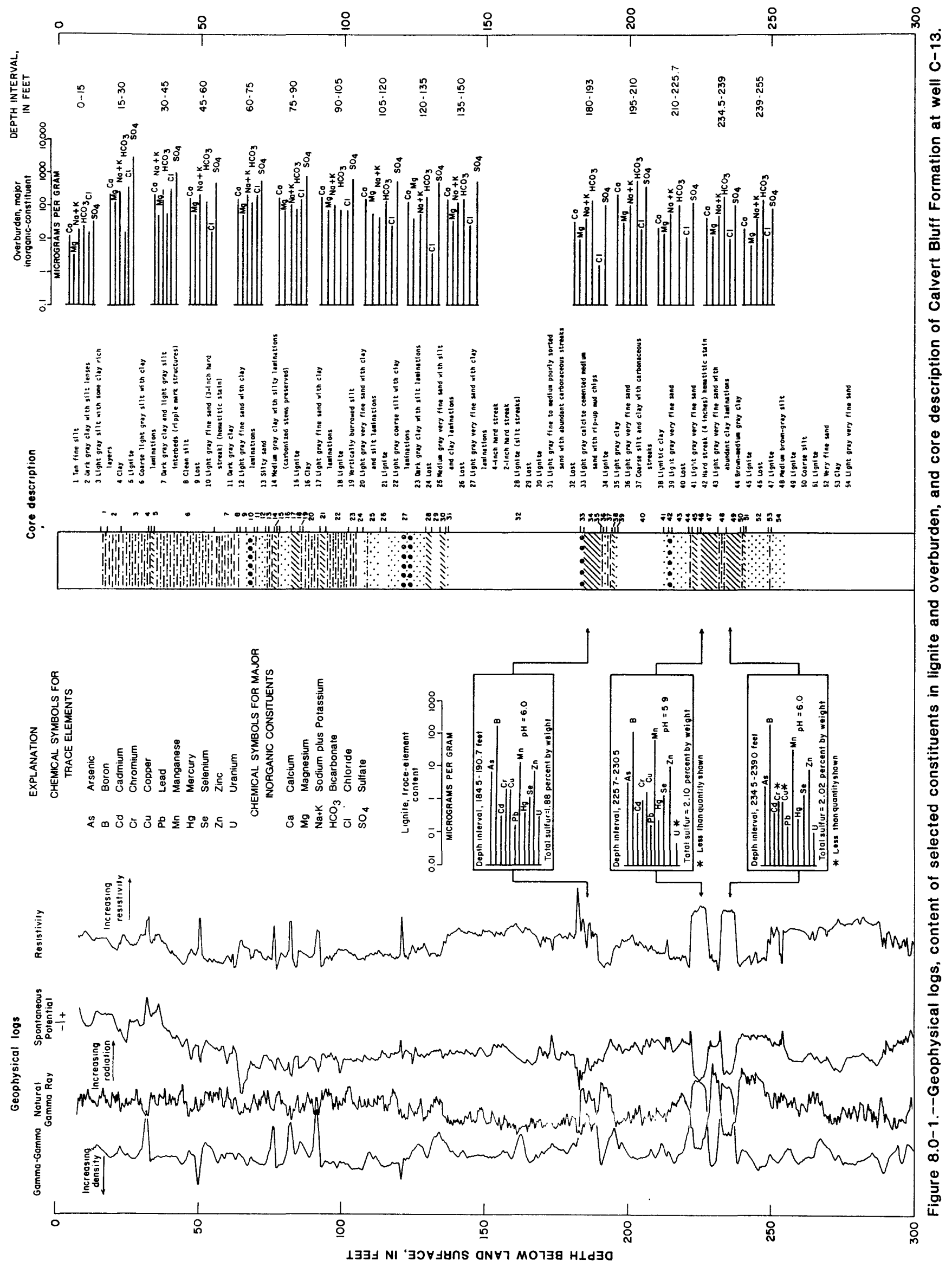


American Geological Institute, 1980, Glossary of Geology (2d ed.): Falls Church, Virginia, American Geological Institute, $749 \mathrm{p}$.

American Public Health Association, and others, 1975, Standard methods for the examination of water and wastewater (14th edition): Washington, D. C., American Public Health Association, 1,193 p.

Baker, F. E., 1979, Soil survey of Bastrop County, Texas: U.S. Soil Conservation Service report, $73 \mathrm{p}$.

Baker, V. R., 1975, Flood hazards along the Balcones Escarpment in central Texas, Alternative approaches to their recognition, mapping, and management: Austin, University of Texas Bureau of Economic Geology, Geological Circular 75-5, 22 p.

Barnes, V. E., 1974, Geologic atlas of Texas--Austin sheet: Austin, University of Texas Bureau of Economic Geology map, scale $1: 250,000$.

Bishop, M. A., 1977, Engineering geology study of highwall stability for a proposed lignite mine in Grimes County, Texas: College Station, Texas A\&M University, unpublished Master's thesis.

Chow, Ven Te, ed., 1964, Handbook of applied hydrology: New York, McGraw-Hi1 1 , 1964.

Dowell, C. L., and Petty, R. G., 1971, Dams and reservoirs in Texas, Part III, Texas Water Development Board Report 126.

Elliott, J. E., 1945, Bastrop fault contiguous to Haupt Bend-Colorado River, Bastrop County, Texas: Austin, University of Texas Bureau of Economic Geology openfile report, $16 \mathrm{p}$. 1947a, Hooper Bend-Cedar Creek area southwest of Hooper Bend on the Colorado River,
Bastrop County, Texas: Austin, University of Texas Bureau of Economic Geology open-file report, $16 \mathrm{p}$.

1947b, Powell Bend Fault, contiguous to the L. Leveryn, Highsmith, and C. S. Smith survey, Bastrop County, Texas: Austin, University of Texas Bureau of Economic Geology open-file report, $10 \mathrm{p}$.

Fisher, W. L. 1963, Lignites of the Texas Gulf Coastal Plain: Austin, University of Texas Bureau of Economic Geology Report of Investigations $50,164 \mathrm{p}$.

Follett, C. R., 1970, Ground-water resources of Bastrop County, Texas: Texas water Development Board Report 109, $138 \mathrm{p}$.

Guyton, W. F., 1942, Results of pumping tests of wells at Camp Swift, Texas: U.S. Geological Survey open-file report, $27 \mathrm{p}$.

Hall, D. W., 1981, Preliminary hydrogeologic, investigations related to possible mining operations, Bastrop County, Texas: Austin, Texas, Hydro-Search, Inc., $70 \mathrm{p}$.

Hem, J. D., 1970, Study and interpretation of the chemical characteristics of natural water ( $2 \mathrm{~d}$ ed.): U.S. Geological Survey WaterSupply Paper 1473, 363 p.

Hershfield, D. M., 1971, Rainfall frequency atlas of the United States. U.S. Weather Bureau Technical Paper 40, $115 \mathrm{p}$.

Kaiser, W. R., 1976, Calvert Bluff (Wilcox Group) sedimentation and the occurrence of lignite at Alcoa and Butler, Texas: Austin, University of Texas Bureau of Economic Geology Research Note $2,10 \mathrm{p}$.

Kaiser, W. R., Ayers, W. B., Jr., and La Brie, L. W., 1980, Lignite resources in Texas: Austin, University of Texas Bureau of Econ- 
omic Geology Report of Investigations 104, $52 \mathrm{p}$.

Kaiser, W. R., Johnson, J. E., and Bach, W. N., 1978, Sandbody geometry and the occurrence of liynite in the Eocene of Texas: Austin, University of Texas Bureau of Economic Geology Geological Circular 78-4, 19 p.

Langbein, W. B., and Iseri, K. T., 1960, General introduction and hydrologic definitions: U.S. Geological Survey Water-Supply Paper 1541-A, 29 p.

Mathewson, C. C. (project director), 1979, The impact of surface lignite mining on surface and ground-water quality: College Station, Texas A\&M University, Texas Energy Advisory Council, $56 \mathrm{p}$.

Mckee, J. E., and Wolf, H. W., 1963, Water-quality criteria (2d ed.): California State Water Quality Board Publication 3-A, 548 p. National Academy of Science and $\mathrm{Na}$ tional Academy of Engineering, 1973, Water-quality criteria, 1972: U.S. Government Printing Office, 594 p.

National Technical Advisory Comnittee to the Secretary of the Interior, 1968, Water-quality criteria: U.S. Government Printing Office,
$234 \mathrm{p}$.

Thrush, P. W., 1968, A dictionary of mining, mineral, and related terms: U.S. Bureau of Mines, $1269 \mathrm{p}$.

U.S. Bureau of Land Management, 1980, Proposed Camp Swift lignite leasing, Bastrop County, Texas: Santa Fe, New Mexico, U.S. Bureau of Land Management Draft Environmental Impact Statement.

U.S. Environmental Protection Agency, 1976 [1977], Quality criteria for water: U.S. Government Printing Office, $256 \mathrm{p}$. 1977a, National interim primary drinking-water regulations: U.S. Government Printing Office, 159 p.

1977b, National secondary drinking-water regulations: Federal Register, v. 42, no. 62, Thursday, March 31, Part I, p. 1714217147.

1982, U.S. Geological Survey Water resources data for Texas, Volume 3: U.S. Geological Survey Survey Water-Data Report, TX-82-3, $491 \mathrm{p}$.

U.S. Soil Conservation Service, 1959, Inventory and use of sedimentation data in Texas: Texas Board of Water Engineers Bullet in 5912, $85 \mathrm{p}$. 


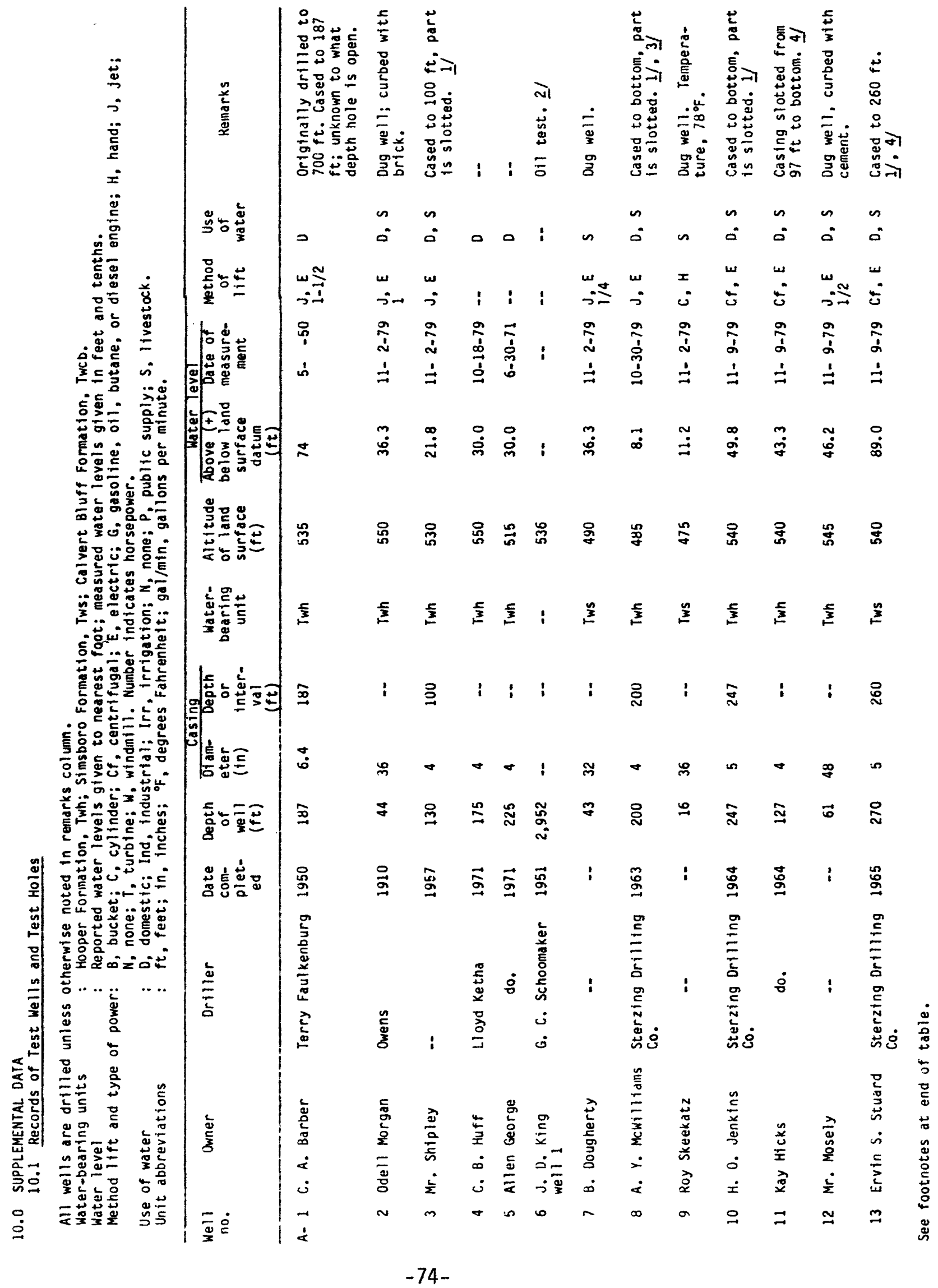




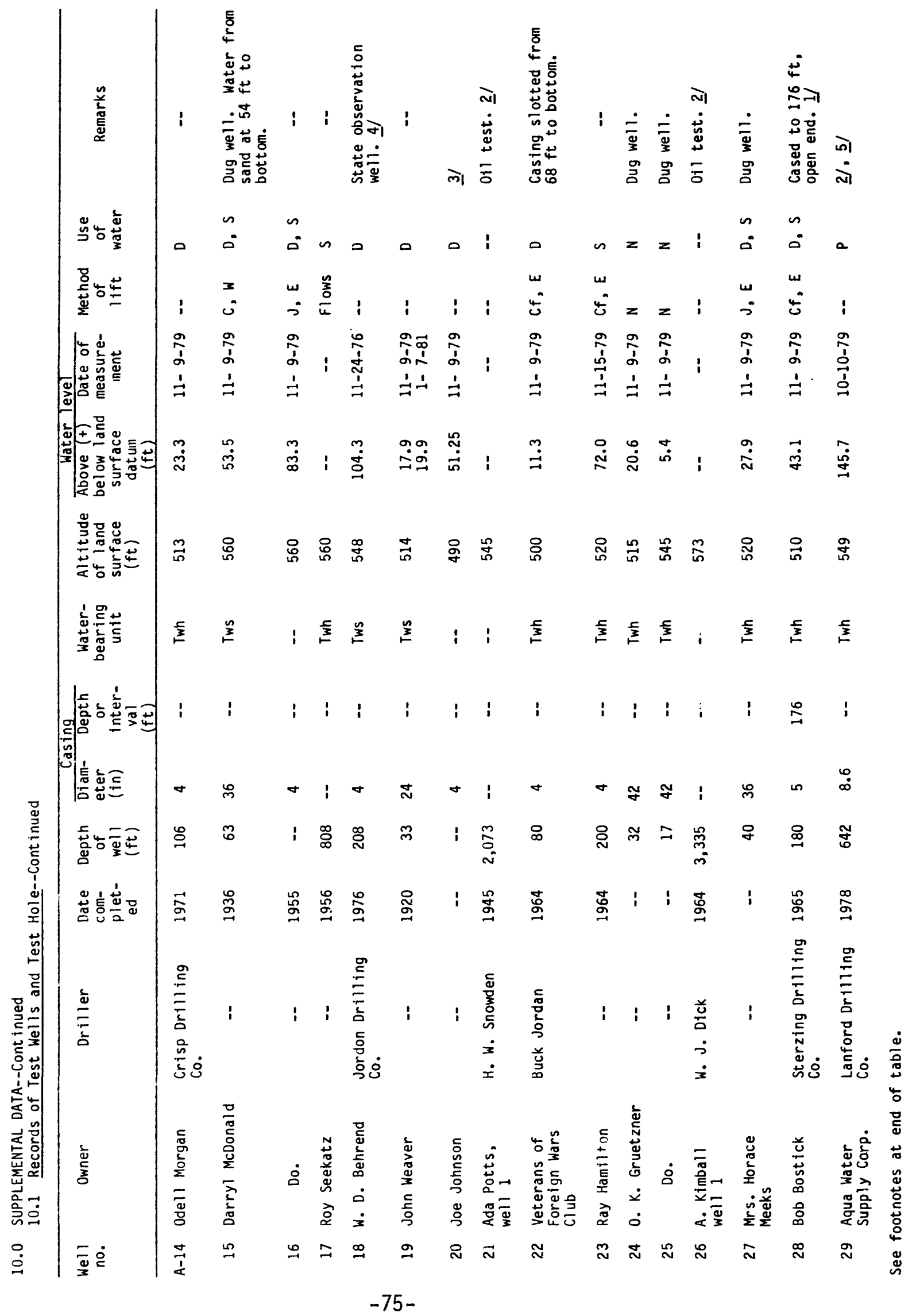




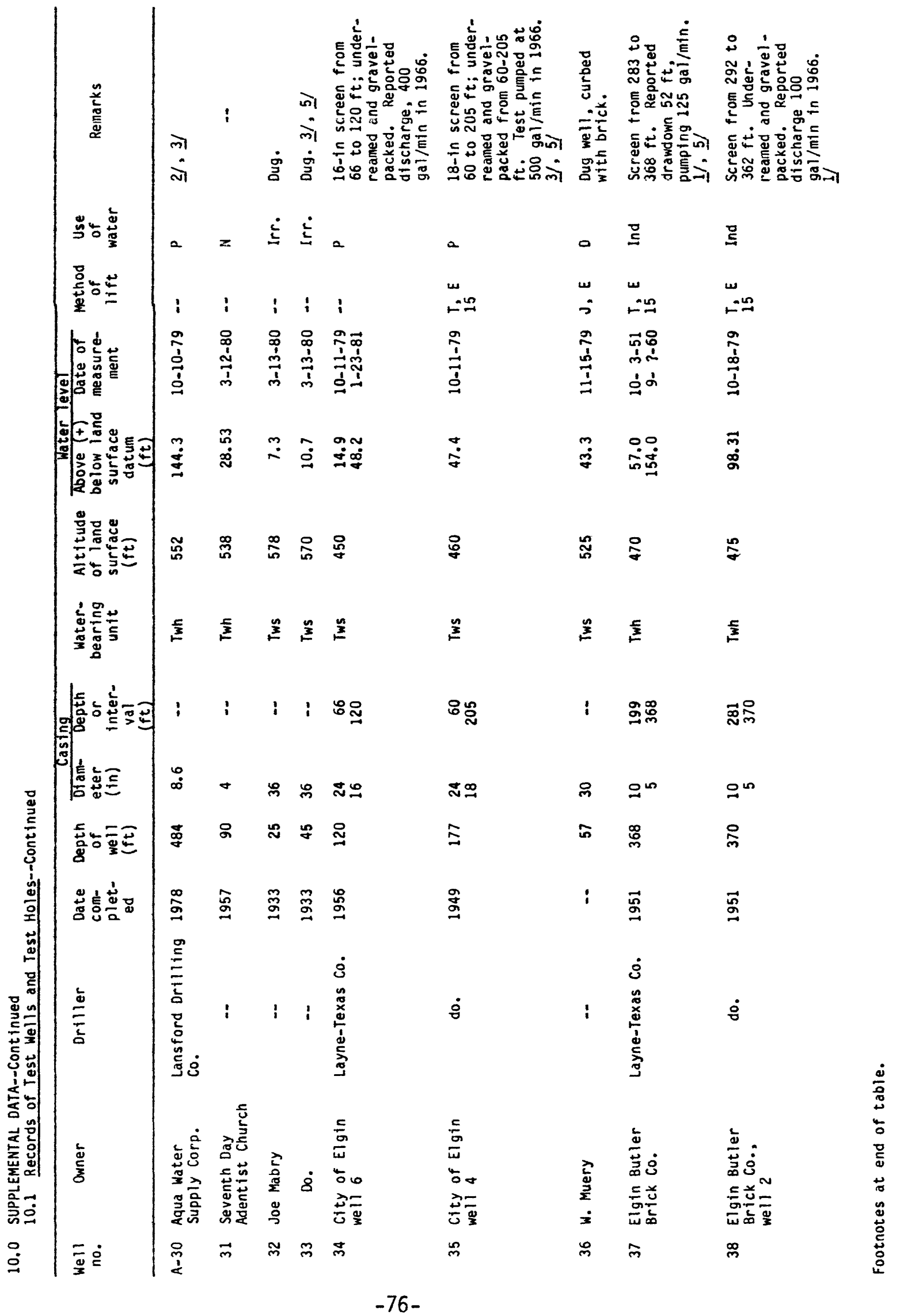




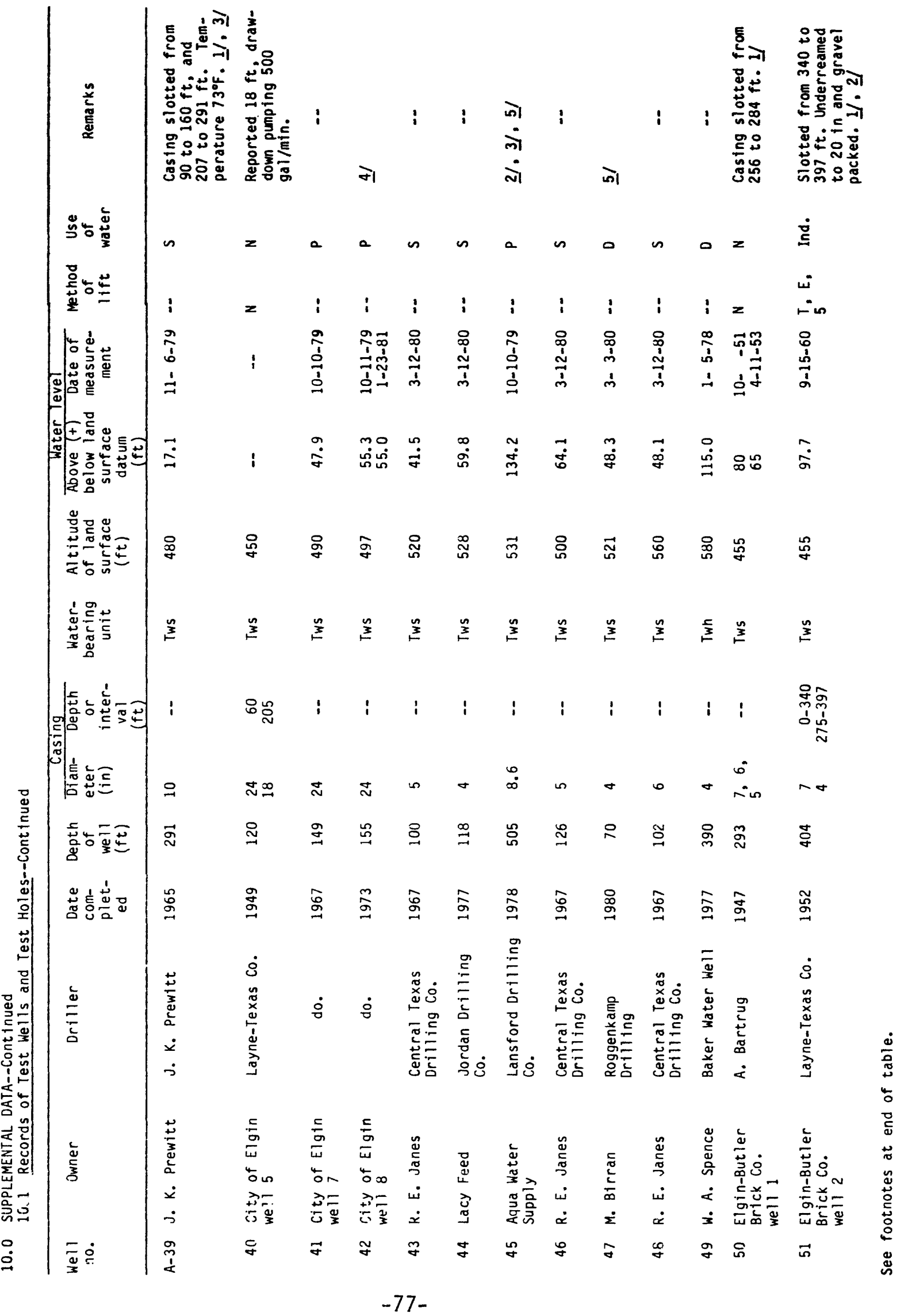




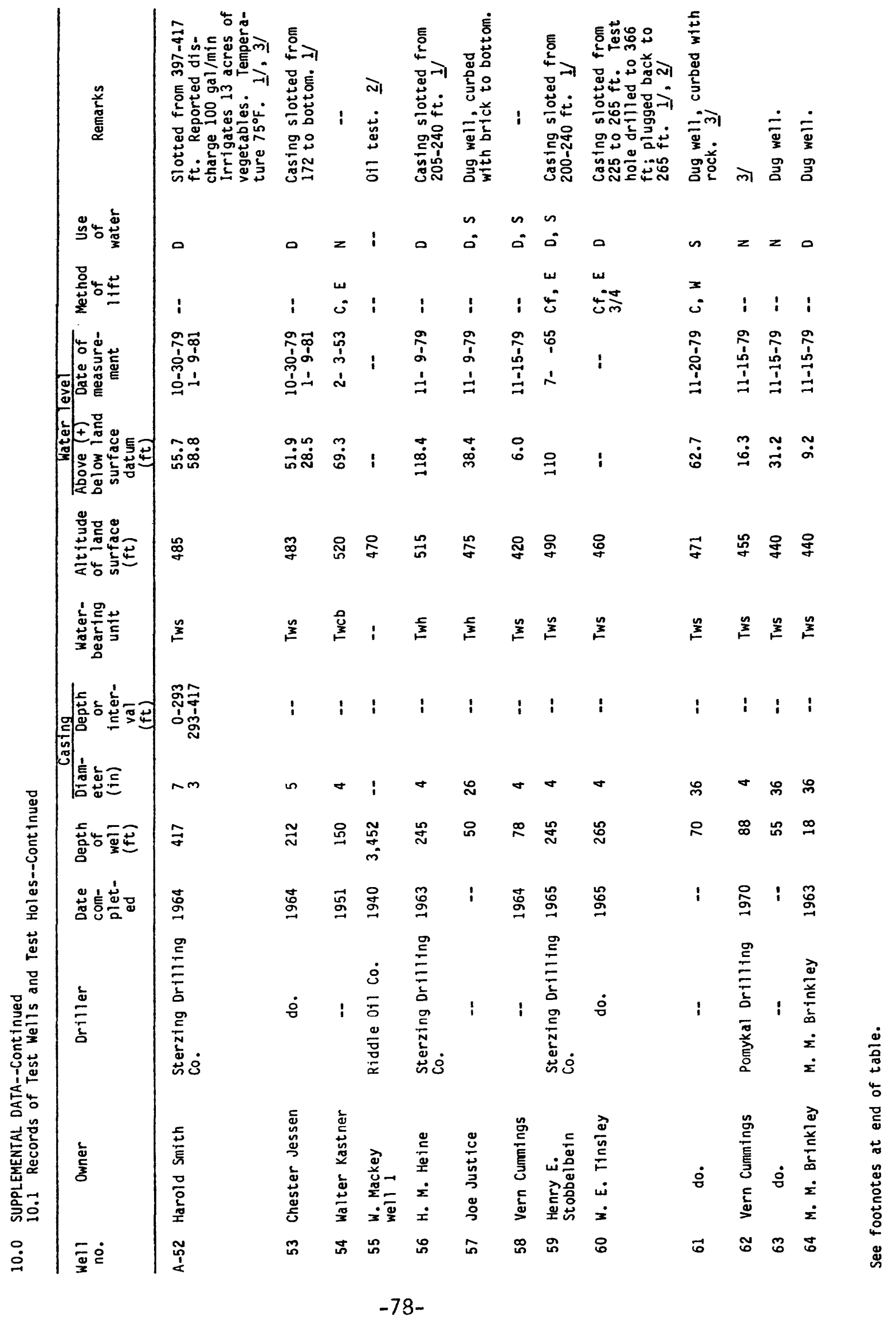




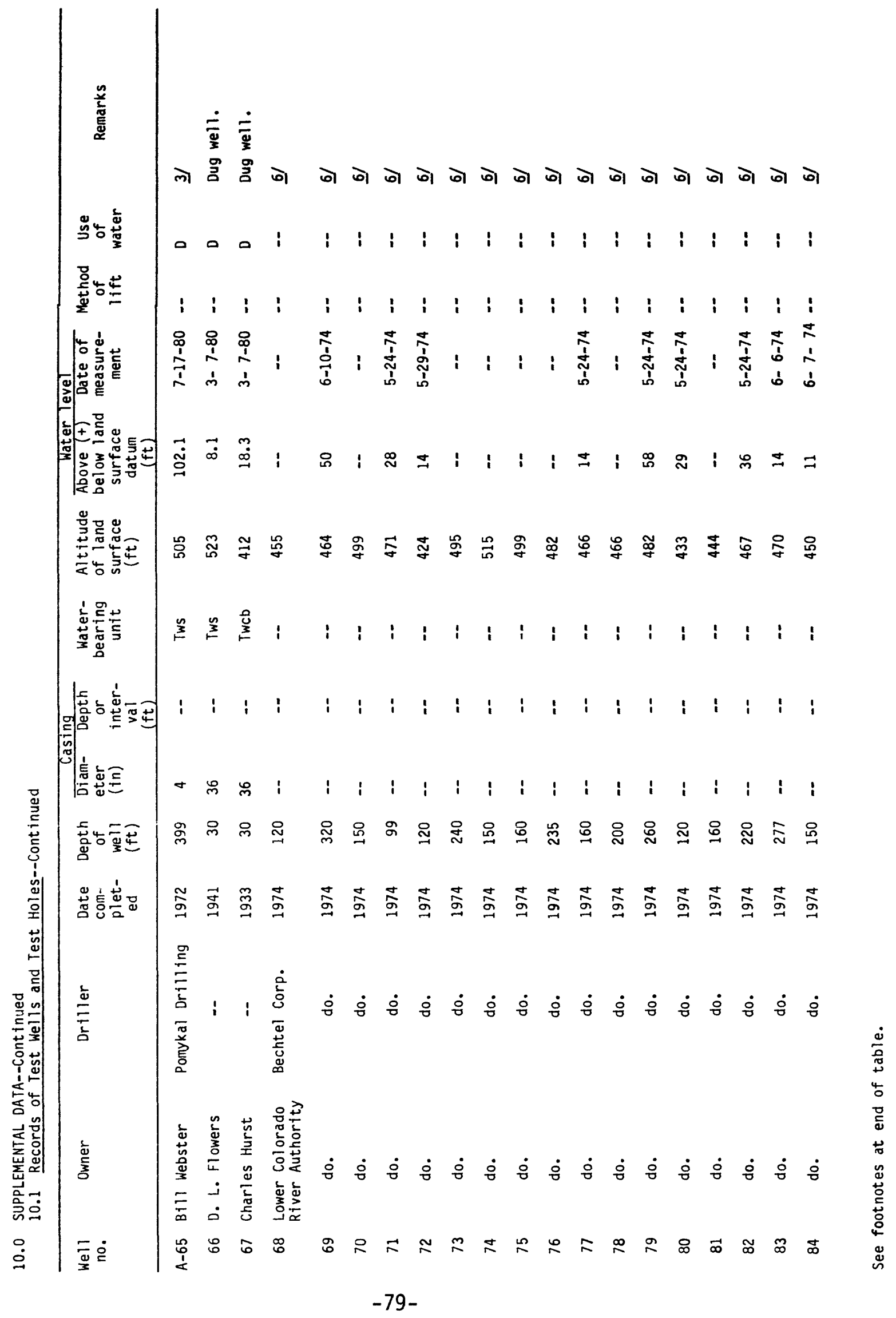




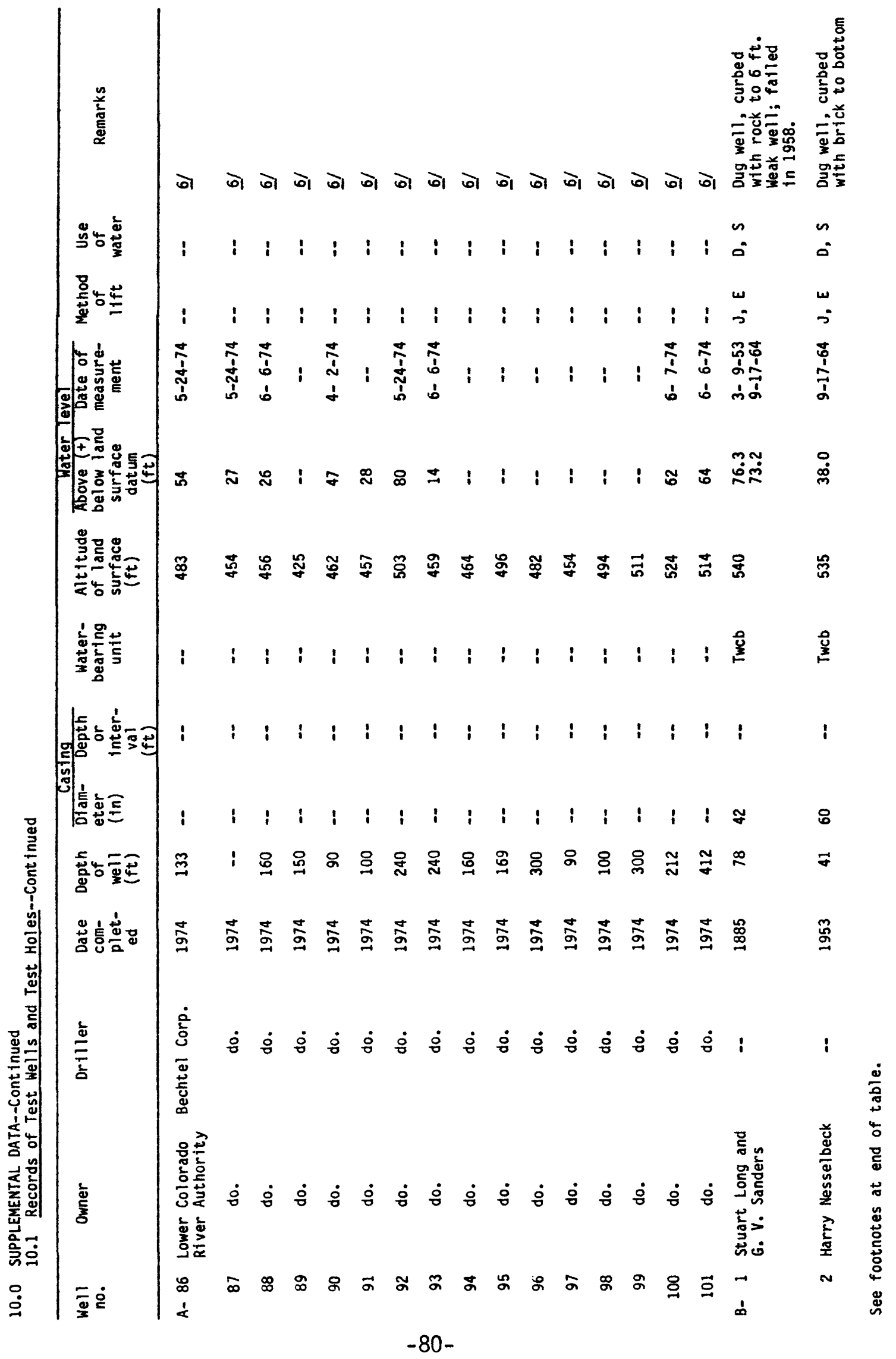




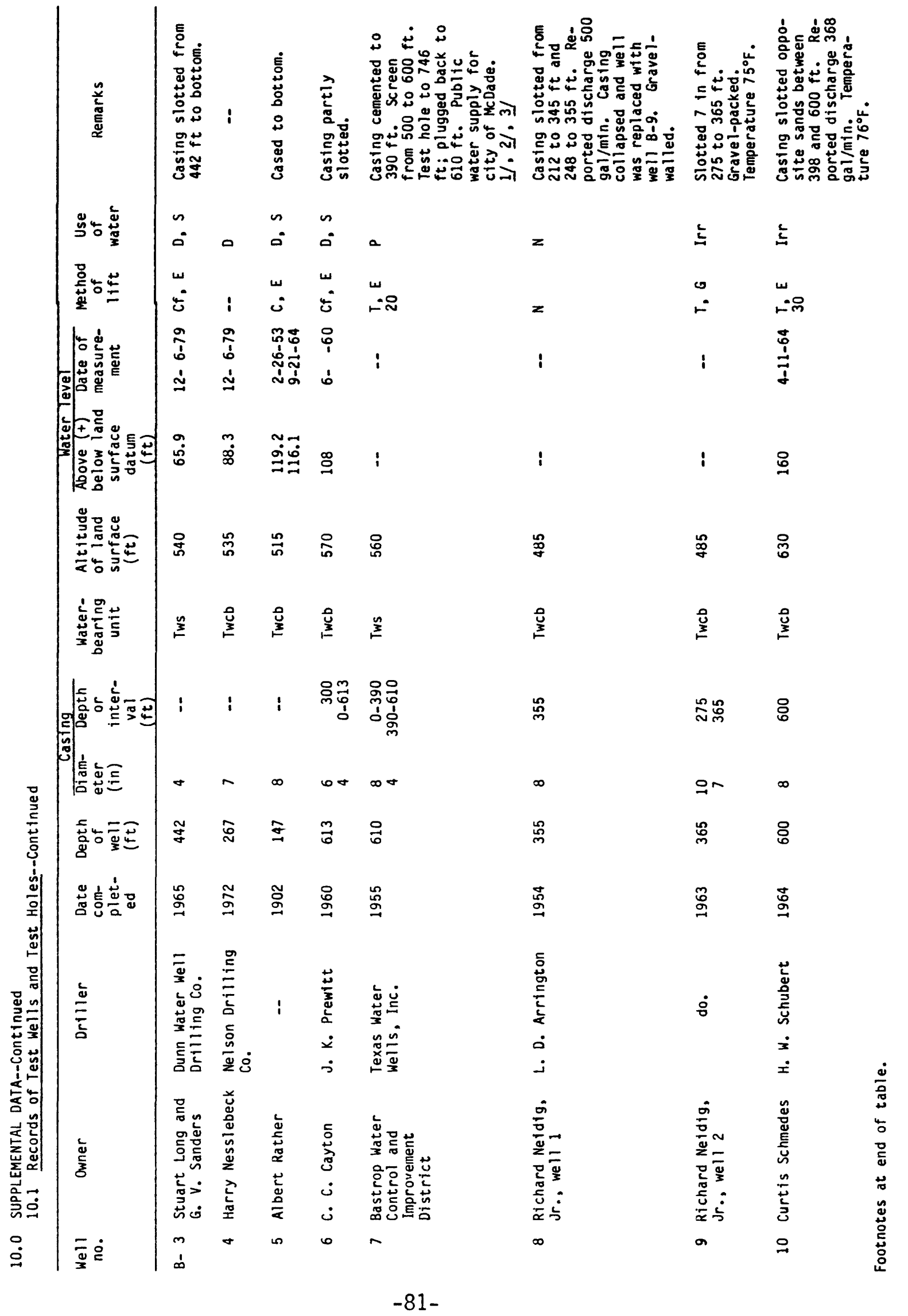




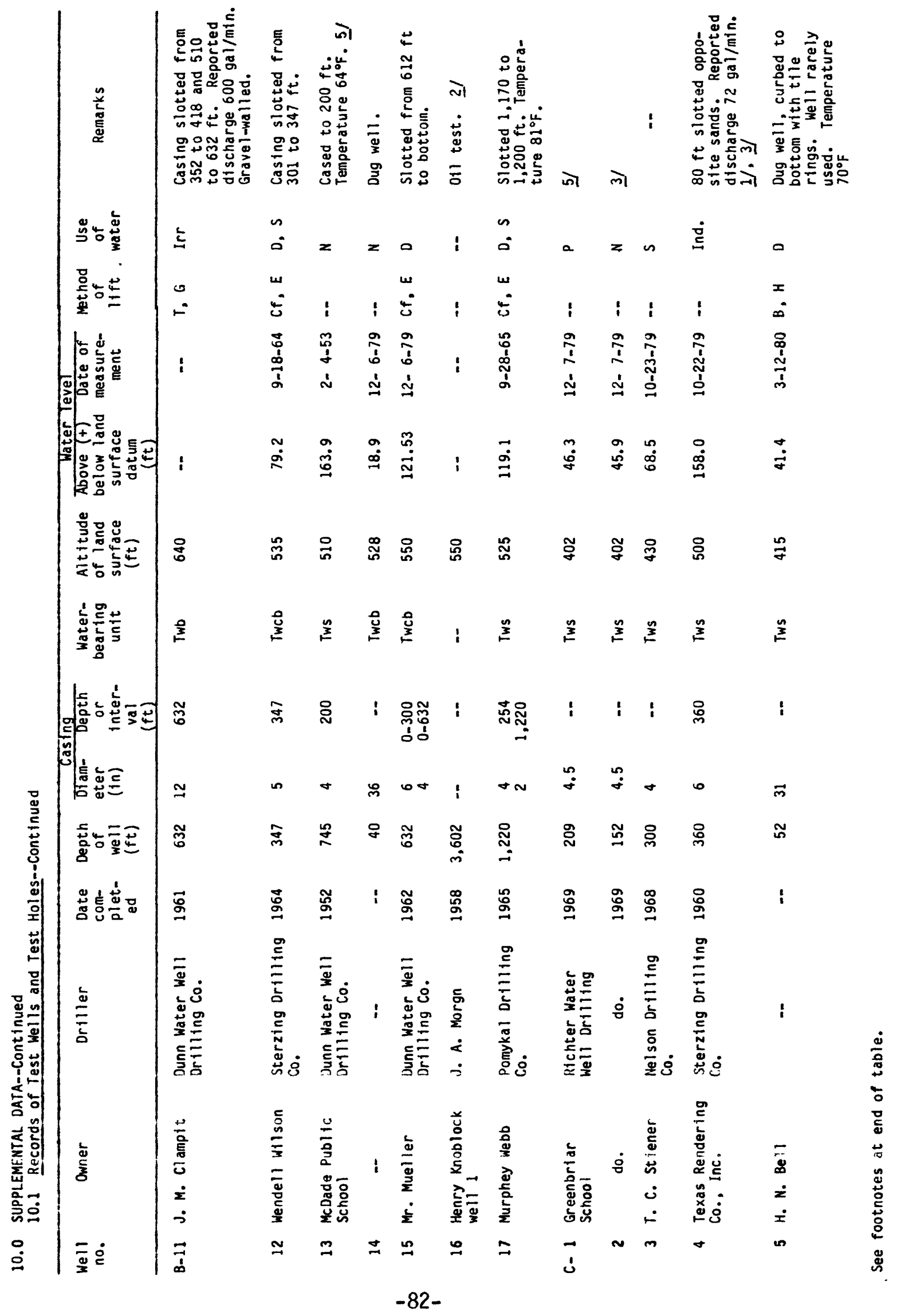




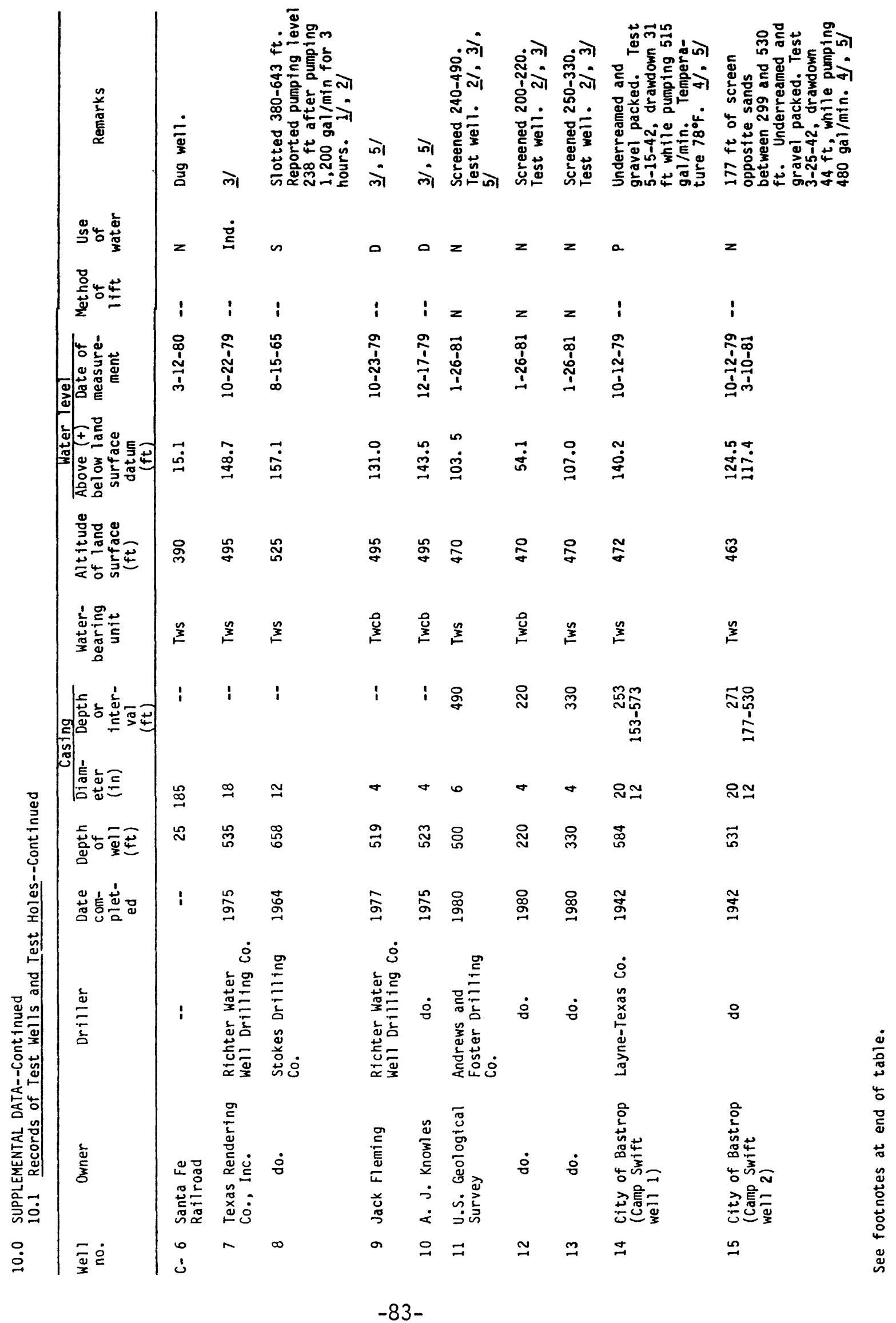




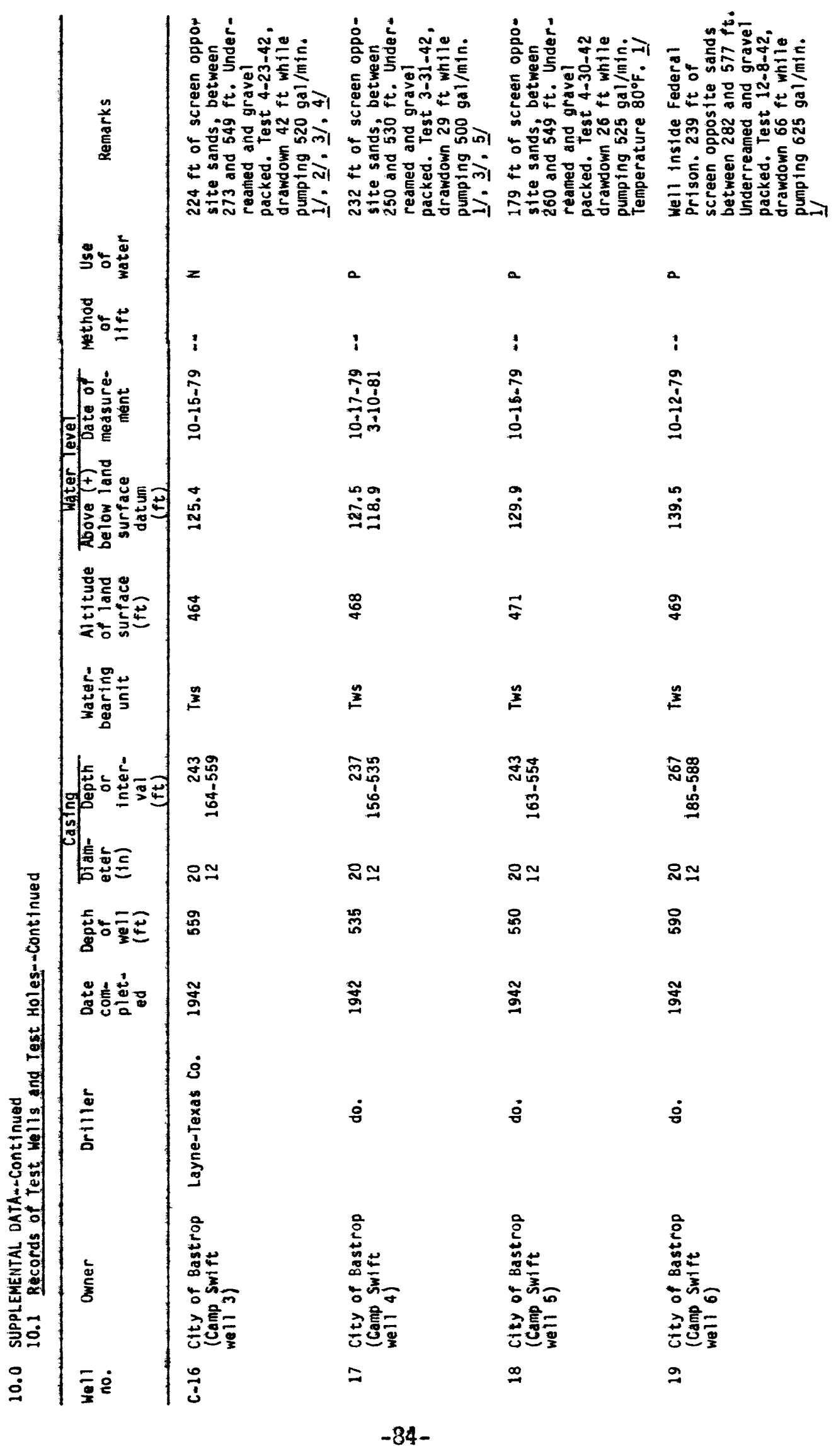

: 


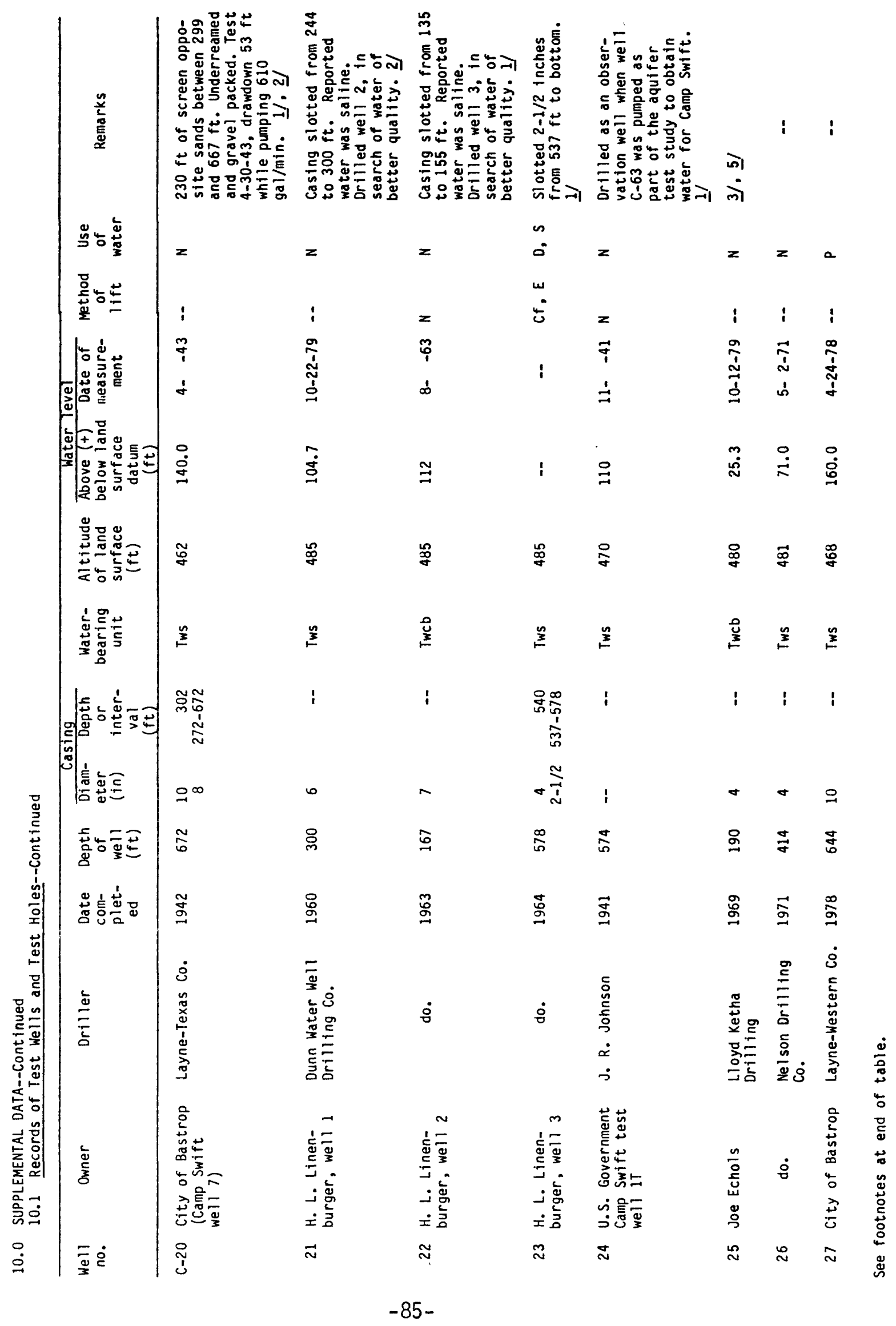




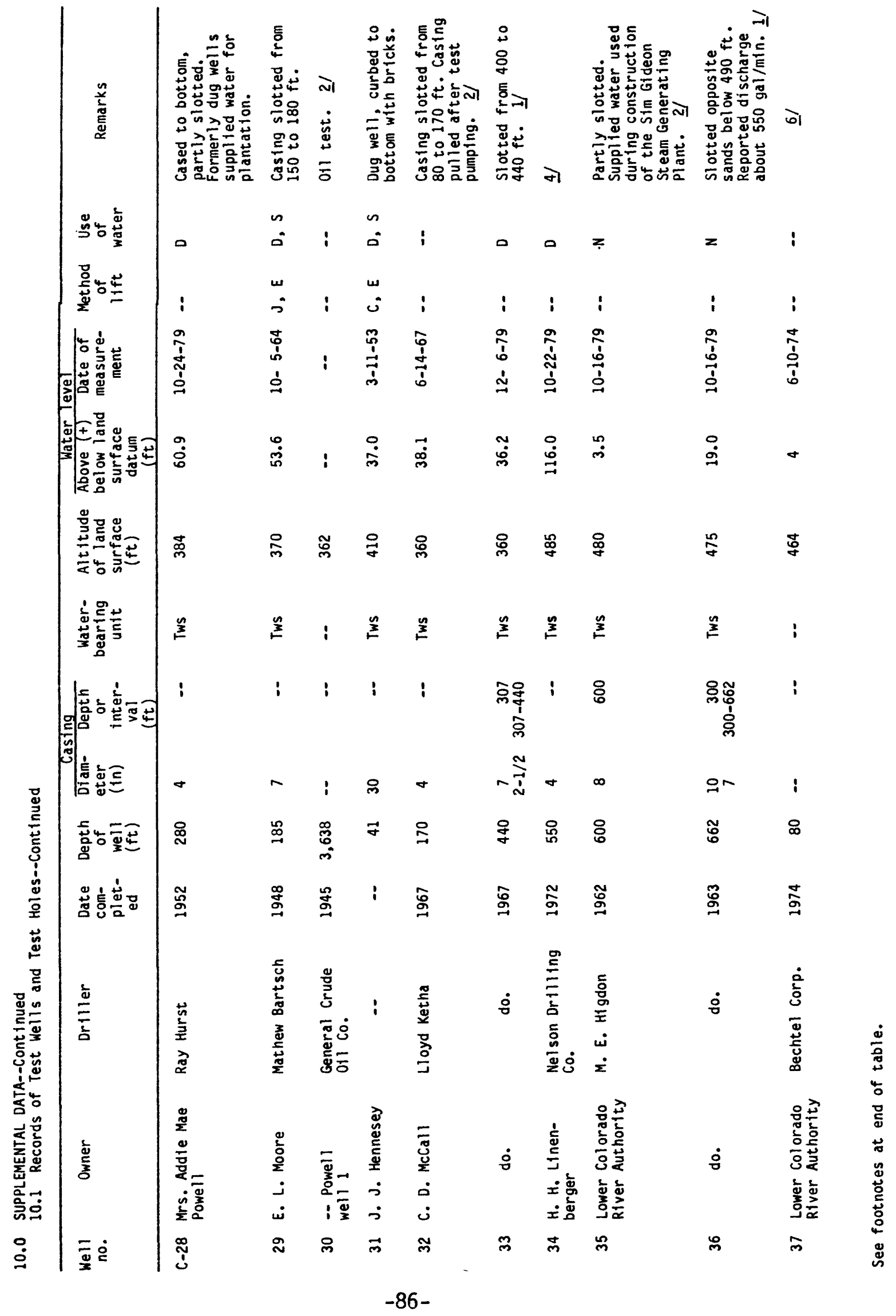




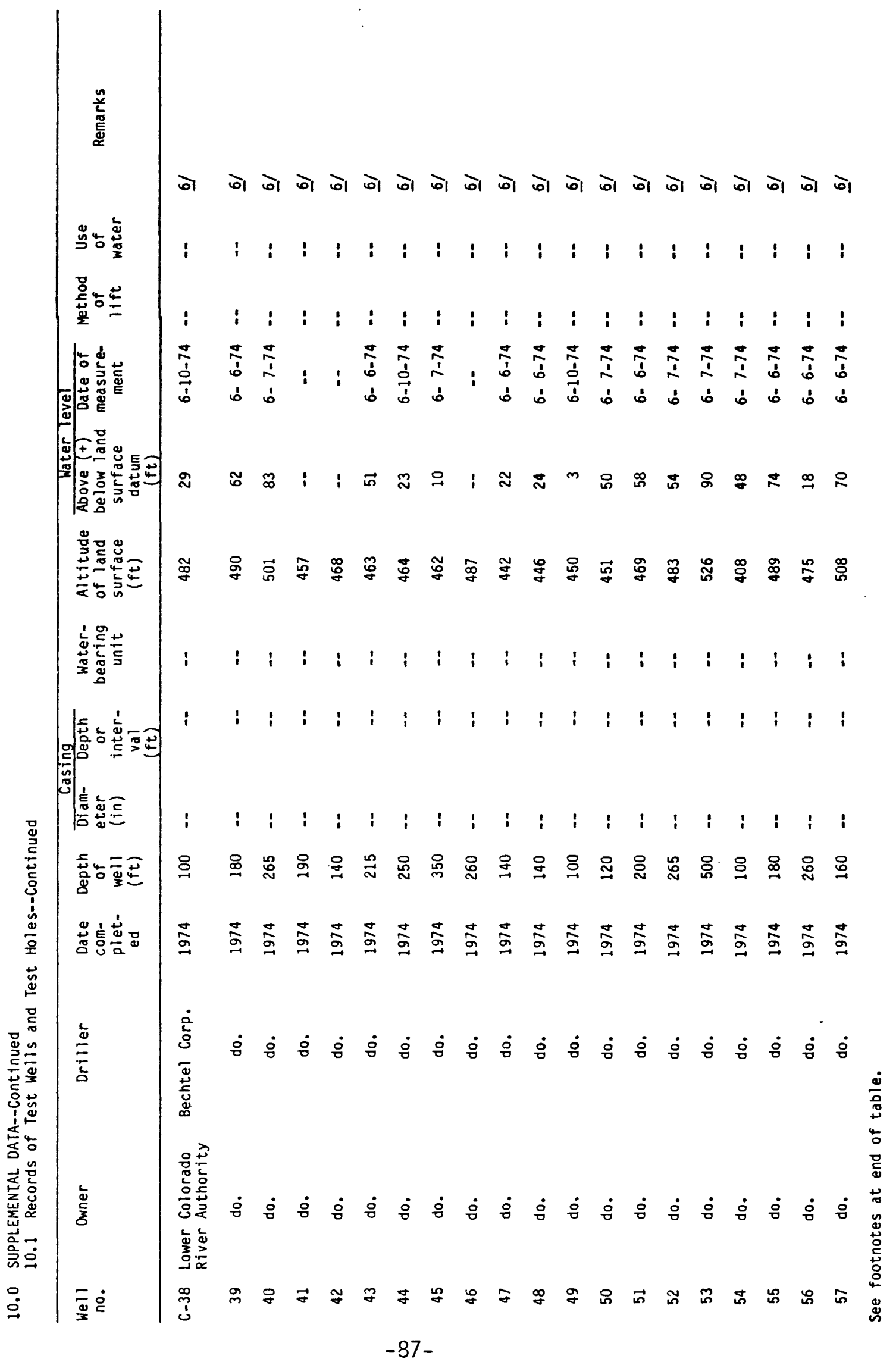




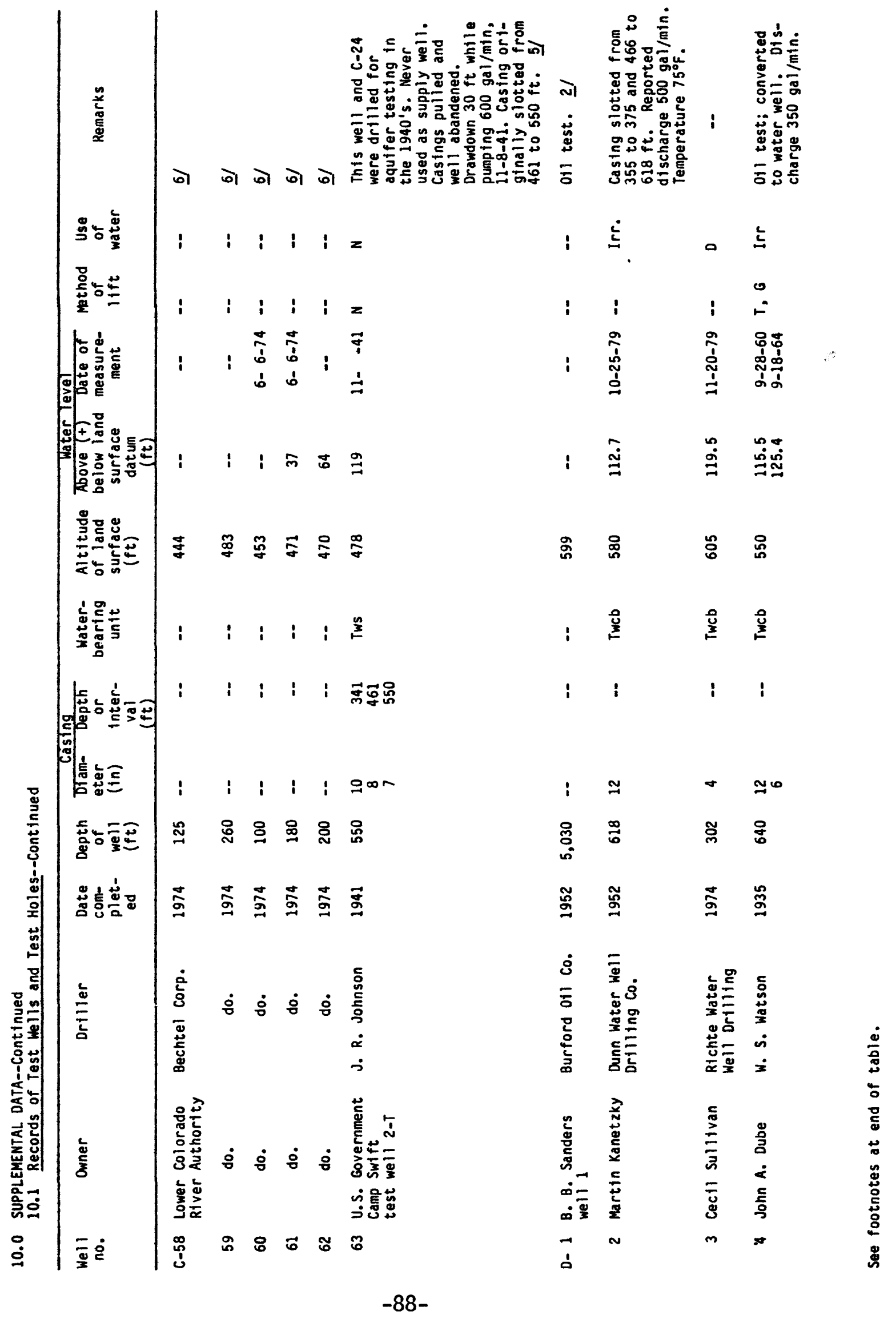




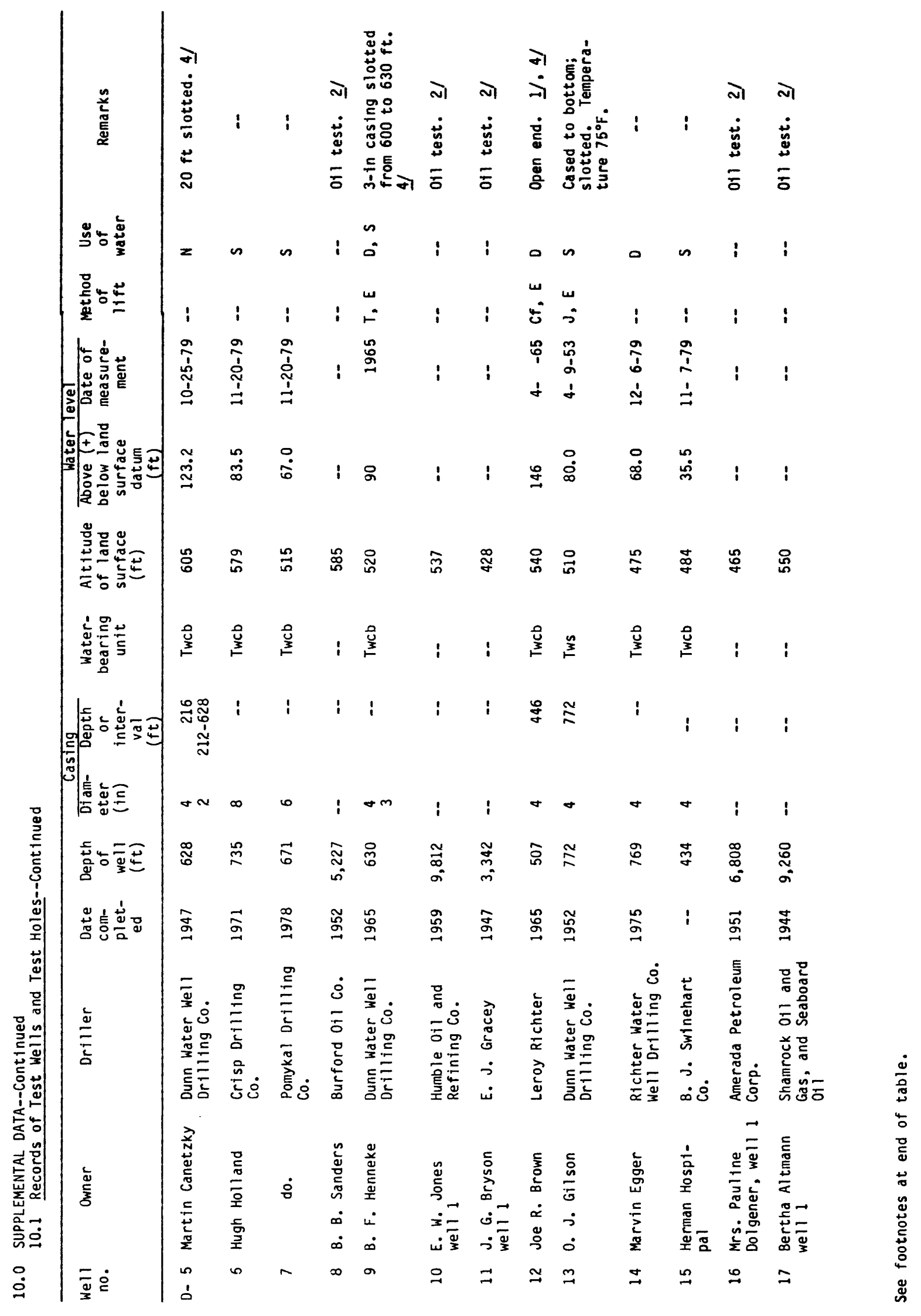




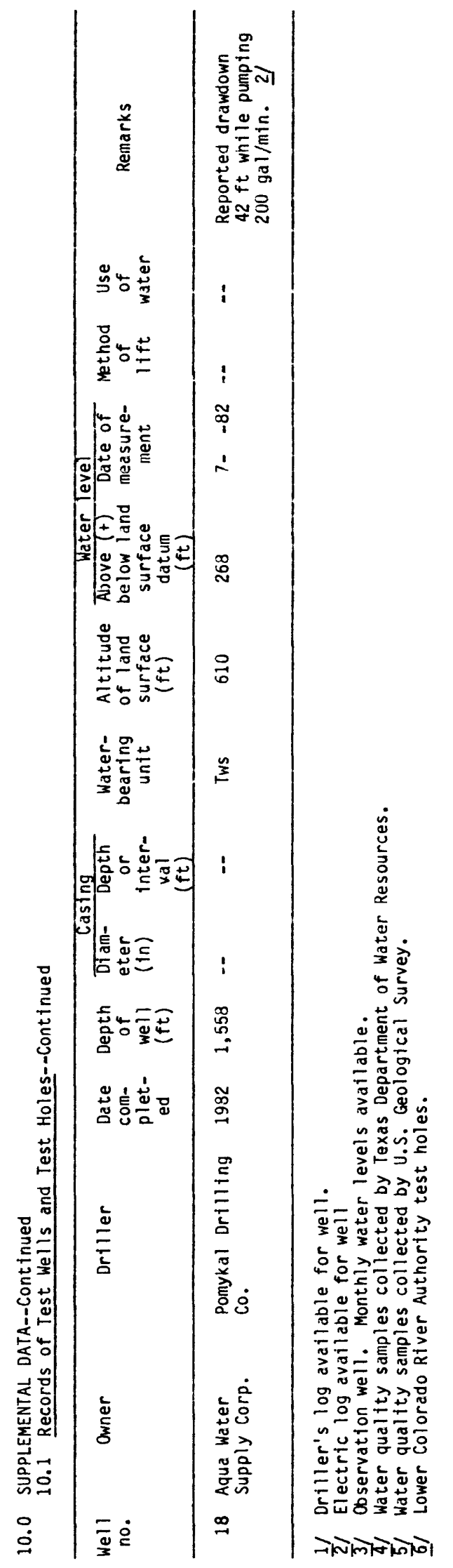




\subsection{SUPPLEMENTAL DATA}

\subsection{Daily-Mean Discharge for Gaging Stations: Big Sandy Creek near McDade and Big Sandy Creek near Elgin.}

\section{COLORADO RIVER BASIN}

08159165 BIG SANDY CREEK NEAR MCDADE. TX

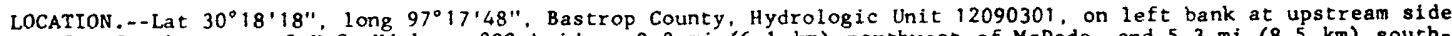
of left abutment of U.S. Highway 290 bridge, $3.8 \mathrm{mi}(6.1 \mathrm{~km})$ northwest of McDade, and $5.3 \mathrm{mi}(8.5 \mathrm{~km}) \mathrm{south}-$ east of Elgin.

DRAINAGE AREA. $--38.7 \mathrm{mi}^{2}\left(100.2 \mathrm{~km}^{2}\right)$.

\section{WATER-DISCHARGE RECORDS}

PERIOD OF RECORD.--July 1979 to current year.

GAGE.-Water-stage recorder. Altitude of gage is $422 \mathrm{ft}(128.6 \mathrm{~m})$. from topographic map.

REMARKS.--Water-discharge records fair. No known regulation or diversion. Station is part of hydrologic-research project to study effects of lignite strip mining on the local water resources. Station has automatic waterquality sampler. Two recording rain gages are located in the watershed.

EXTREMES FOR PERIOD OF RECORD,--Maximum discharge, $989 \mathrm{ft}^{3} / \mathrm{s}\left(28.0 \mathrm{~m}^{3} / \mathrm{s}\right)$ Mar. 27 , 1980, gage height, $12.20 \mathrm{ft}$ $(3.719 \mathrm{~m})$, from rating curve extended above $424 \mathrm{ft}^{3} / \mathrm{s}\left(12.0 \mathrm{~m}^{3} / \mathrm{s}\right)$; no flow for many days each year.

EXTREMES FOR PERIOD JULY TO SEPTEMBER 1979. - Maximum discharge, $331 \mathrm{ft}^{3} / \mathrm{s}\left(9.37 \mathrm{~m}^{3} / \mathrm{s}\right)$ July 27 at $2400 \mathrm{hours}, \mathrm{gage}$ height. $7.05 \mathrm{ft}(2.149 \mathrm{~m})$, no other peak above base of $325 \mathrm{ft}^{3} / \mathrm{s}\left(9.20 \mathrm{~m}^{3} / \mathrm{s}\right)$; no flow Sept. $9-19$.

EXTREMES FOR CURRENT YEAR.--Peak discharges above base of $325 \mathrm{ft}^{3} / \mathrm{s}\left(9.20 \mathrm{~m}^{3} / \mathrm{s}\right.$ ) and maximum (*):

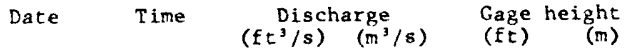

$$
\begin{aligned}
& \begin{array}{llrrrr}
\text { Mar. } 27 & 2115 & \star 989 & 28.0 & \text { a12.20 } & 3.719 \\
\text { May } 14 & 0230 & 984 & 27.9 & 12.17 & 3.709
\end{array} \\
& \text { a From rating curve extended above } 424 \mathrm{ft}^{3} / \mathrm{s} \\
& \left(9.20 \mathrm{~m}^{3} / \mathrm{s}\right) \text {. }
\end{aligned}
$$

Minimum discharge, no flow for many days.

$$
\text { DISCHARGE, IN CUBIC FEET PER SECOND, JULY TO SEPTEMBER } 1979
$$
MEAN VALUES

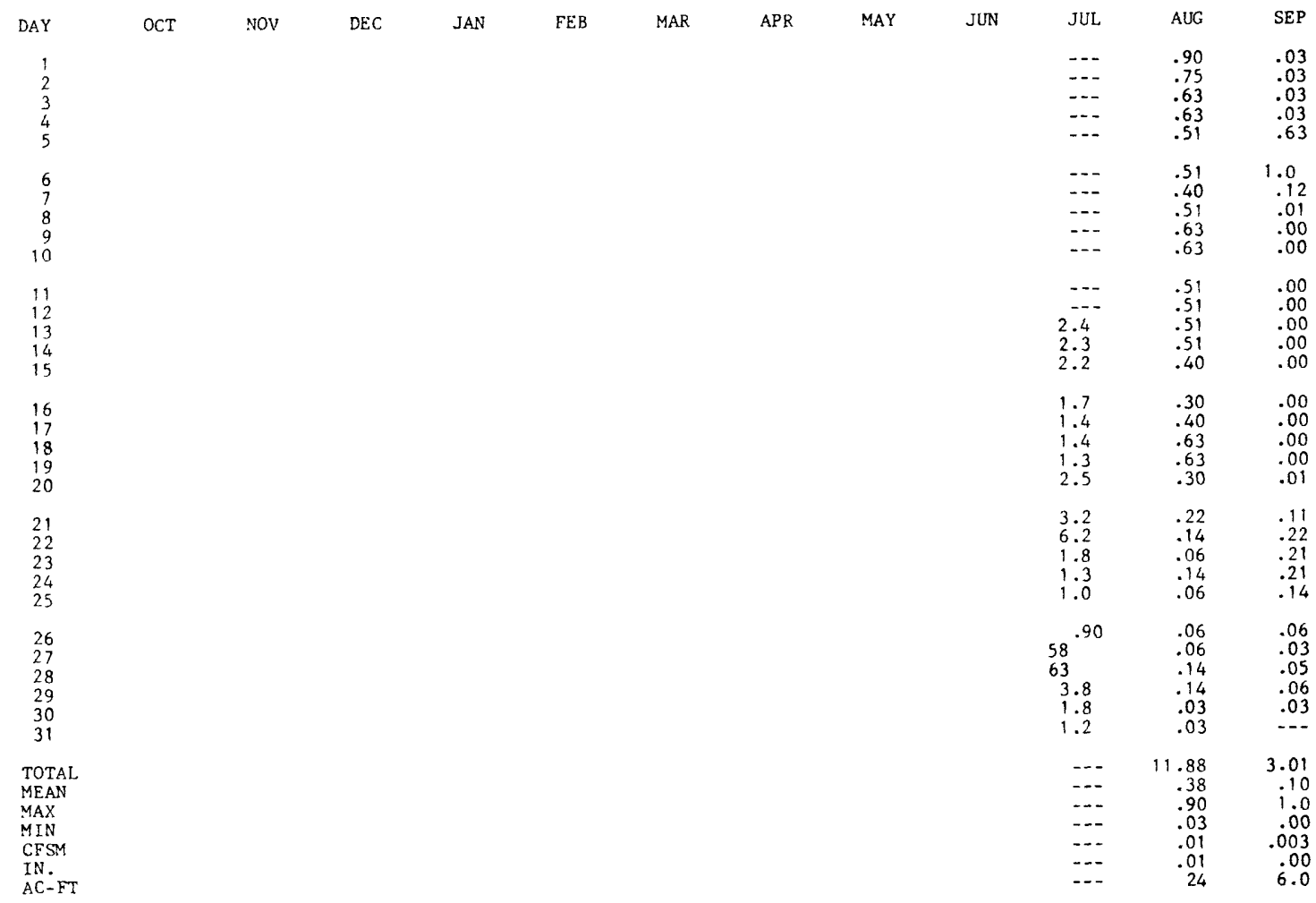

WTR YR 1979 TOTAL - MEAN - MAX - MIN - CFSM - IN. - AC-FT - 
10.0 SUPPLEMENTAL DATA--Continued

10.2 Daily-Mean Discharge for Gaging Stations: Big Sandy Creek near McDade and Big Sandy Creek near Elgin--Continued

COLORADO RIVER BASIN

08159165 BIG SANDY CREEK NEAR MCDADE, TX--Continued

DISCHARGE, IN CUBIC FEET PER SECOND, WATER YEAR OCTOBER 1979 TO SEPTEMBER 1980

\begin{tabular}{|c|c|c|c|c|c|c|c|c|c|c|c|c|}
\hline DAY & $\mathrm{OCT}$ & NOV & DEC & JAN & FEB & MAR & APR & MAY & JUN & JUL & AUG & SEP \\
\hline $\begin{array}{l}1 \\
2 \\
3 \\
4 \\
5\end{array}$ & $\begin{array}{l}.04 \\
.03 \\
.04 \\
.66 \\
.01\end{array}$ & $\begin{array}{l}.00 \\
.00 \\
.00 \\
.00 \\
.00\end{array}$ & $\begin{array}{l}.03 \\
.04 \\
.06 \\
.10 \\
.14\end{array}$ & $\begin{array}{l}.69 \\
.63 \\
.66 \\
.63 \\
.55\end{array}$ & $\begin{array}{l}2.2 \\
2.1 \\
1.9 \\
1.9 \\
1.8\end{array}$ & $\begin{array}{l}8.5 \\
4.0 \\
2.6 \\
2.4 \\
2.1\end{array}$ & $\begin{array}{l}8.3 \\
6.6 \\
5.7 \\
4.6 \\
3.3\end{array}$ & $\begin{array}{l}7.4 \\
4.1 \\
1.5 \\
.93 \\
.54\end{array}$ & $\begin{array}{l}1.7 \\
1.5 \\
1.4 \\
1.4 \\
1.2\end{array}$ & $\begin{array}{l}.02 \\
.00 \\
.00 \\
.00 \\
.00\end{array}$ & $\begin{array}{l}.00 \\
.00 \\
.00 \\
.00 \\
.00\end{array}$ & $\begin{array}{l}.00 \\
.00 \\
.00 \\
.00 \\
.00\end{array}$ \\
\hline $\begin{array}{r}6 \\
7 \\
8 \\
9 \\
10\end{array}$ & $\begin{array}{l}.02 \\
.04 \\
.06 \\
.03 \\
.02\end{array}$ & $\begin{array}{l}.00 \\
.00 \\
.00 \\
.00 \\
.00\end{array}$ & $\begin{array}{l}.17 \\
.14 \\
.18 \\
.22 \\
.22\end{array}$ & $\begin{array}{l}.64 \\
.73 \\
.63 \\
.63 \\
.63\end{array}$ & $\begin{array}{l}1.8 \\
1.9 \\
2.0 \\
2.5 \\
2.3\end{array}$ & $\begin{array}{l}1.8 \\
1.8 \\
1.8 \\
1.7 \\
1.6\end{array}$ & $\begin{array}{l}2.7 \\
2.9 \\
2.8 \\
2.5 \\
2.2\end{array}$ & $\begin{array}{l}.39 \\
.94 \\
2.8 \\
4.0 \\
2.2\end{array}$ & $\begin{array}{l}1.3 \\
1.3 \\
1.1 \\
1.0 \\
1.1\end{array}$ & $\begin{array}{l}.00 \\
.00 \\
.00 \\
.00 \\
.00\end{array}$ & $\begin{array}{l}.00 \\
.00 \\
.00 \\
.00 \\
.00\end{array}$ & $\begin{array}{l}.00 \\
.00 \\
.00 \\
.00 \\
.00\end{array}$ \\
\hline $\begin{array}{l}11 \\
12 \\
13 \\
14 \\
15\end{array}$ & $\begin{array}{l}.04 \\
.04 \\
.03 \\
.03 \\
.04\end{array}$ & $\begin{array}{l}.00 \\
.00 \\
.01 \\
.01 \\
.00\end{array}$ & $\begin{array}{l}.25 \\
.56 \\
2.4 \\
1.3 \\
.36\end{array}$ & $\begin{array}{l}.79 \\
.64 \\
.52 \\
.56 \\
.69\end{array}$ & $\begin{array}{l}2.1 \\
1.8 \\
2.6 \\
2.1 \\
2.1\end{array}$ & $\begin{array}{l}1.5 \\
1.6 \\
1.7 \\
1.5 \\
1.5\end{array}$ & $\begin{array}{l}1.8 \\
1.7 \\
4.5 \\
2.7 \\
2.0\end{array}$ & $\begin{array}{c}1.2 \\
14 \\
193 \\
469 \\
136\end{array}$ & $\begin{array}{l}1.2 \\
1.2 \\
1.1 \\
.88 \\
.63\end{array}$ & $\begin{array}{l}.00 \\
.00 \\
.00 \\
.00 \\
.00\end{array}$ & $\begin{array}{l}.00 \\
.00 \\
.00 \\
.00 \\
.00\end{array}$ & $\begin{array}{l}.00 \\
.00 \\
.00 \\
.00 \\
.00\end{array}$ \\
\hline $\begin{array}{l}16 \\
17 \\
18 \\
19 \\
20\end{array}$ & $\begin{array}{l}.03 \\
.03 \\
.03 \\
.01 \\
.00\end{array}$ & $\begin{array}{l}.01 \\
.02 \\
.02 \\
.00 \\
.00\end{array}$ & $\begin{array}{l}.16 \\
.06 \\
.06 \\
.06 \\
.19\end{array}$ & $\begin{array}{l}.81 \\
.89 \\
.89 \\
1.2 \\
6.7\end{array}$ & $\begin{array}{l}6.1 \\
7.5 \\
4.2 \\
3.9 \\
2.7\end{array}$ & $\begin{array}{l}1.6 \\
1.9 \\
1.7 \\
1.8 \\
2.0\end{array}$ & $\begin{array}{c}1.0 \\
1.2 \\
.50 \\
.51 \\
.47\end{array}$ & $\begin{array}{l}78 \\
23 \\
8.0 \\
5.7 \\
5.2\end{array}$ & $\begin{array}{l}.47 \\
.36 \\
.24 \\
.17 \\
.14\end{array}$ & $\begin{array}{l}.00 \\
.00 \\
.00 \\
.00 \\
.00\end{array}$ & $\begin{array}{l}.00 \\
.00 \\
.00 \\
.00 \\
.00\end{array}$ & $\begin{array}{l}.00 \\
.00 \\
.00 \\
.00 \\
.00\end{array}$ \\
\hline $\begin{array}{l}21 \\
22 \\
23 \\
24 \\
25\end{array}$ & $\begin{array}{l}.01 \\
.00 \\
.00 \\
.00 \\
.01\end{array}$ & $\begin{array}{l}.00 \\
.00 \\
.00 \\
.00 \\
.00\end{array}$ & $\begin{array}{l}1.2 \\
1.8 \\
2.5 \\
3.3 \\
2.0\end{array}$ & $\begin{array}{c}5.1 \\
42 \\
18 \\
5.2 \\
3.6\end{array}$ & $\begin{array}{l}2.8 \\
2.2 \\
2.0 \\
1.8 \\
1.7\end{array}$ & $\begin{array}{l}1.9 \\
1.7 \\
1.8 \\
1.9 \\
2.0\end{array}$ & $\begin{array}{r}.41 \\
.40 \\
.46 \\
11^{.46}\end{array}$ & $\begin{array}{l}3.8 \\
3.2 \\
2.5 \\
2.5 \\
2.2\end{array}$ & $\begin{array}{l}.19 \\
.18 \\
.18 \\
.04 \\
.03\end{array}$ & $\begin{array}{l}.00 \\
.00 \\
.00 \\
.00 \\
.00\end{array}$ & $\begin{array}{l}.00 \\
.00 \\
.00 \\
.00 \\
.00\end{array}$ & $\begin{array}{l}.00 \\
.00 \\
.00 \\
.00 \\
.00\end{array}$ \\
\hline $\begin{array}{l}26 \\
27 \\
28 \\
29 \\
30 \\
31\end{array}$ & $\begin{array}{l}.00 \\
.00 \\
.00 \\
.01 \\
.03 \\
.00\end{array}$ & $\begin{array}{l}.01 \\
.03 \\
.03 \\
.02 \\
.01 \\
. .-\end{array}$ & $\begin{array}{r}1.4 \\
1.4 \\
2.0 \\
11 \\
2.2 \\
1.1\end{array}$ & $\begin{array}{l}3.2 \\
2.6 \\
2.5 \\
2.5 \\
2.5 \\
2.3\end{array}$ & $\begin{array}{l}1.6 \\
2.0 \\
2.1 \\
2.1 \\
- \\
-\end{array}$ & $\begin{array}{c}2.4 \\
303 \\
187 \\
20 \\
11 \\
8.1\end{array}$ & $\begin{array}{l}5.6 \\
1.8 \\
.95 \\
.70 \\
.66 \\
.--\end{array}$ & $\begin{array}{l}2.2 \\
2.1 \\
1.9 \\
1.8 \\
1.9 \\
1.8\end{array}$ & $\begin{array}{l}.01 \\
.01 \\
.01 \\
.03 \\
.04 \\
.--\end{array}$ & $\begin{array}{l}.00 \\
.00 \\
.00 \\
.00 \\
.00 \\
.00\end{array}$ & $\begin{array}{l}.00 \\
.00 \\
.00 \\
.00 \\
.00 \\
.00\end{array}$ & $\begin{array}{l}.00 \\
.00 \\
.00 \\
.00 \\
.00 \\
--\end{array}$ \\
\hline $\begin{array}{l}\text { TOTAL } \\
\text { MEAN } \\
\text { MAX } \\
\text { MIN } \\
\text { CFSM } \\
\text { IN. } \\
\text { AC-FT } \\
(\dagger+)\end{array}$ & $\begin{array}{r}1.29 \\
.042 \\
.66 \\
.00 \\
.001 \\
.00 \\
2.6 \\
1.46\end{array}$ & $\begin{array}{r}.17 \\
.006 \\
.03 \\
.00 \\
.000 \\
.00 \\
.31\end{array}$ & $\begin{array}{r}36.60 \\
1.18 \\
11 \\
.03 \\
.03 \\
.04 \\
73 \\
3.15\end{array}$ & $\begin{array}{r}109.61 \\
3.54 \\
42 \\
.52 \\
.09 \\
.11 \\
217 \\
2.40\end{array}$ & $\begin{array}{r}73.8 \\
2.54 \\
7.5 \\
1.6 \\
.07 \\
.07 \\
146 \\
2.13\end{array}$ & $\begin{array}{r}585.9 \\
18.9 \\
303 \\
1.5 \\
.49 \\
1.56 \\
1160 \\
3.70\end{array}$ & $\begin{array}{r}80.42 \\
2.68 \\
11 \\
.40 \\
.07 \\
.08 \\
160 \\
2.40\end{array}$ & $\begin{array}{r}983.80 \\
31.7 \\
469 \\
.39 \\
.82 \\
.95 \\
7950 \\
6.46\end{array}$ & $\begin{array}{r}20.11 \\
.67 \\
i .7 \\
.01 \\
.02 \\
.02 \\
40 \\
.64\end{array}$ & $\begin{array}{l}.02 \\
.001 \\
.02 \\
.00 \\
.000 \\
.00 \\
.04 \\
.24\end{array}$ & $\begin{array}{l}.00 \\
.000 \\
.00 \\
.00 \\
.000 \\
.00 \\
.00 \\
.93\end{array}$ & $\begin{array}{l}.00 \\
.000 \\
.00 \\
.00 \\
.000 \\
.00 \\
.00 \\
3.07\end{array}$ \\
\hline
\end{tabular}

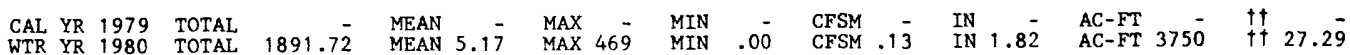

$\dagger \dagger$ Weighted-mean rainfall on watershed, in inches, based on two rain gages. 


\subsection{SUPFLEMENTAL DATA--Continued}

10.2 Daily-Mean Discharge for Gaging Stations: Big Sandy Creek near McDade and Big Sandy Creek near El gin--Continued

COLORADO RIVER BASIN

08159165 BIG SANDY CREEK NEAR MCDADE, TX

LOCATION.--Lat $30^{\circ} 18^{\prime} 18^{\prime \prime}$, Iong $97^{\circ} 17^{\prime} 48^{\prime \prime}$, Bastrop County, Hydrologic Unit 12090301, on left bank at upstream side of left abutment of U.S. Highway 290 bridge, $3.8 \mathrm{mi}\left(6 . \mathrm{l}^{\mathrm{k}} \mathrm{km}\right)$ northwest of McDade, and $5.3 \mathrm{mi}$ ( $\left.8.5 \mathrm{~km}\right)$ southeast of Elgin.

DRAINAGE AREA. $--38.7 \mathrm{mi}^{2}\left(100.2 \mathrm{~km}^{2}\right)$.

PERIOD OF REC.ORD.--July 1979 to current year.

GAGE.--Water-stage recorder. Altitude of gage is $422 \mathrm{ft}(128.6 \mathrm{~m})$, from topographic map.

REMARKS.--Records fair. No known regulation or diversion. Station is part of hydrologic-research project to study effects of lignite strip mining on the local water resources. Station has automatic water-quality sampler. Two recording rain gages are located in the watershed.

EXTREMES FOR PERIOD OF RECORD.--Maximum discharge, $4,410 \mathrm{ft}^{3} / \mathrm{s}\left(125 \mathrm{~m}^{3} / \mathrm{s}\right) \mathrm{June} 11$, 1981 , gage height, $15.74 \mathrm{ft}$ $(4.798 \mathrm{~m})$; no flow for many days each year.

EXTREMES FOR CURRENT YEAR.--Peak discharges above base of $325 \mathrm{ft}^{3} / \mathrm{s}\left(9.20 \mathrm{~m}^{3} / \mathrm{s}\right)$ and maximum (*):

\begin{tabular}{|c|c|c|c|c|c|c|c|c|c|c|c|}
\hline Date & Time & $\begin{array}{r}\text { Disc } \\
\left(\mathrm{ft}^{3} / \mathrm{s}\right)\end{array}$ & $(\mathrm{mg} / \mathrm{s})$ & $\begin{array}{c}\text { Gage } \\
(\mathrm{ft})\end{array}$ & $\begin{array}{r}\text { height } \\
\text { (m) }\end{array}$ & Date & Time & $\begin{array}{r}\text { Disc } \\
\left(\mathrm{ft}^{3} / \mathrm{s}\right)\end{array}$ & $\left(\mathrm{m}^{3} / \mathrm{s}\right)$ & $\begin{array}{c}\text { Gage } \\
(\mathrm{ft})\end{array}$ & $\begin{array}{l}\text { height } \\
\text { (m) }\end{array}$ \\
\hline $\begin{array}{cc}\text { May } & 31 \\
\text { June } & 11\end{array}$ & $\begin{array}{l}0245 \\
0645\end{array}$ & $\begin{array}{r}412 \\
* 4,410\end{array}$ & $\begin{array}{l}11.7 \\
125\end{array}$ & $\begin{array}{r}7.82 \\
15.74\end{array}$ & $\begin{array}{l}2.384 \\
4.798\end{array}$ & $\begin{array}{l}\text { June } 13 \\
\text { June } 16\end{array}$ & $\begin{array}{l}1830 \\
1400\end{array}$ & $\begin{array}{l}1,970 \\
1,940\end{array}$ & $\begin{array}{l}55.8 \\
54.9\end{array}$ & $\begin{array}{l}12.70 \\
12.65\end{array}$ & $\begin{array}{l}3.871 \\
3.856\end{array}$ \\
\hline
\end{tabular}

Minimum discharge, no flow for many days.

DISCHARGE, IN CUBIC FEET PER SECOND, WATER YEAR OCTOBER 1980 TO SEPTEMBER 1981 MEAN VALUES

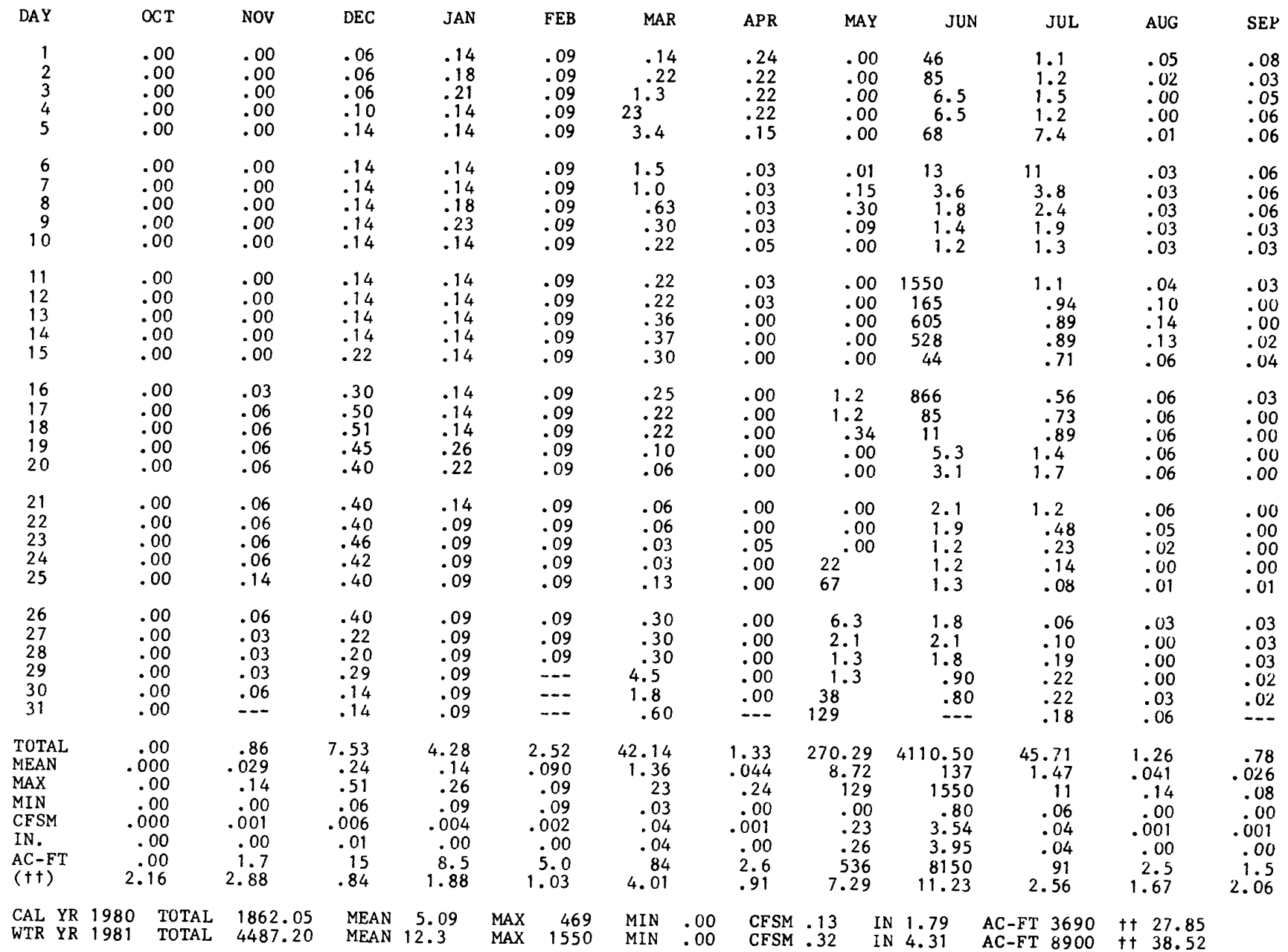

tt Weighted-mean rainfall on watershed, in inches, based on two rain gages. 
COLORADO RIVER BASIN

08159165 BIG SANDY CREEK NEAR MCDADE, TX

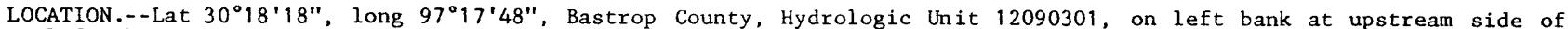
left abutment of U.S. Highway 290 bridge, $3.8 \mathrm{mi}(6.1 \mathrm{~km})$ northwest of McDade, $5.3 \mathrm{mi}$ ( $8.5 \mathrm{~km}$ ) southeast of Elgin, and $14.2 \mathrm{mi}(22.8 \mathrm{~km})$ upstream from mouth.

DRAINAGE AREA. $--38.7 \mathrm{mi}^{2}\left(100.2 \mathrm{~km}^{2}\right)$.

PERIOD OF RECORD.--July 1979 to current year.

GAGE.--Water-stage recorder. Altitude of gage is $422 \mathrm{ft}(128.6 \mathrm{~m})$, from topographic map.

REMARKS.--Records fair except those for 0ct. 1 to Nov. 19, which are poor. No known regulation or diversion. Two recording rain gages are located in the watershed. Several observations of water temperature were made during the year.

EXTREMES FOR PERIOD OF RECORD.--Maximum discharge, 4,410 $\mathrm{ft}^{3} / \mathrm{s}\left(125 \mathrm{~m}^{3} / \mathrm{s}\right) \mathrm{June} 11$, 1981 and May 13 , 1982 , gage height, $15.74 \mathrm{ft}(4.798 \mathrm{~m})$; no flow for many days each year.

EXTREMES FOR CURRENT YEAR.--Maximum discharge, $4,410 \mathrm{ft}^{3} / \mathrm{s}\left(125 \mathrm{~m}^{3} / \mathrm{s}\right)$ May 13 at 1115 hours, gage height, $15.74 \mathrm{ft}$ $(4.798 \mathrm{~m})$, no other peak above base of $325 \mathrm{ft}^{3} / \mathrm{s}\left(9.20 \mathrm{~m}^{3} / \mathrm{s}\right)$; no flow for many days.

DISCHARGE, IN CUBIC FEET PER SECOND, WATER YEAR OCTOBER 1981 TO SEPTEMBER 1982

\begin{tabular}{|c|c|c|c|c|c|c|c|c|c|c|c|c|}
\hline DAY & OCT & NOV & DEC & JAN & FEB & MAR & APR & MAY & JUN & JUL & AUG & SEP \\
\hline $\begin{array}{l}1 \\
2 \\
3 \\
4 \\
5\end{array}$ & $\begin{array}{l}.00 \\
.00 \\
.00 \\
.00 \\
.00\end{array}$ & $\begin{array}{r}298 \\
459 \\
324 \\
65 \\
26\end{array}$ & $\begin{array}{l}.90 \\
.63 \\
.63 \\
.63 \\
.90\end{array}$ & $\begin{array}{l}.75 \\
.75 \\
1.4 \\
1.2 \\
.90\end{array}$ & $\begin{array}{l}.94 \\
.82 \\
1.0 \\
.92 \\
.68\end{array}$ & $\begin{array}{l}.89 \\
.89 \\
.83 \\
.75 \\
.75\end{array}$ & $\begin{array}{l}.83 \\
.75 \\
.75 \\
.75 \\
.74\end{array}$ & $\begin{array}{l}1.6 \\
1.4 \\
1.2 \\
1.2 \\
1.2\end{array}$ & $\begin{array}{l}.73 \\
1.0 \\
1.1 \\
1.2 \\
1.2\end{array}$ & $\begin{array}{l}1.5 \\
.75 \\
.40 \\
.22 \\
.14\end{array}$ & $\begin{array}{l}.00 \\
.00 \\
.00 \\
.00 \\
.00\end{array}$ & $\begin{array}{l}.00 \\
.00 \\
.00 \\
.00 \\
.00\end{array}$ \\
\hline $\begin{array}{r}6 \\
7 \\
8 \\
9 \\
10\end{array}$ & $\begin{array}{l}.00 \\
.00 \\
.00 \\
.00 \\
.00\end{array}$ & $\begin{array}{r}2.6 \\
1.8 \\
2.5 \\
74 \\
144\end{array}$ & $\begin{array}{l}1.3 \\
1.3 \\
1.4 \\
1.3 \\
1.3\end{array}$ & $\begin{array}{l}.89 \\
.88 \\
.75 \\
.75 \\
.67\end{array}$ & $\begin{array}{l}.56 \\
.51 \\
.58 \\
.75 \\
.75\end{array}$ & $\begin{array}{l}.75 \\
.63 \\
.63 \\
.63 \\
.63\end{array}$ & $\begin{array}{l}.55 \\
.51 \\
.67 \\
1.0 \\
1.4\end{array}$ & $\begin{array}{l}2.0 \\
2.1 \\
1.5 \\
1.3 \\
1.1\end{array}$ & $\begin{array}{l}.76 \\
.37 \\
.30 \\
.51 \\
.63\end{array}$ & $\begin{array}{l}.03 \\
.00 \\
.00 \\
.00 \\
.00\end{array}$ & $\begin{array}{l}.00 \\
.00 \\
.00 \\
.00 \\
.00\end{array}$ & $\begin{array}{l}.00 \\
.00 \\
.00 \\
.00 \\
.00\end{array}$ \\
\hline $\begin{array}{l}11 \\
12 \\
13 \\
14 \\
15\end{array}$ & $\begin{array}{r}.00 \\
.00 \\
113^{.00} \\
118^{.0}\end{array}$ & $\begin{array}{r}83 \\
9.4 \\
4.8 \\
3.0 \\
2.2\end{array}$ & $\begin{array}{c}1.2 \\
.90 \\
.90 \\
1.0 \\
.90\end{array}$ & $\begin{array}{l}.63 \\
1.0 \\
1.3 \\
1.2 \\
1.1\end{array}$ & $\begin{array}{l}.94 \\
1.0 \\
.89 \\
.63 \\
.63\end{array}$ & $\begin{array}{l}.95 \\
1.4 \\
1.4 \\
1.1 \\
.89\end{array}$ & $\begin{array}{l}1.0 \\
.76 \\
.66 \\
.63 \\
.63\end{array}$ & $\begin{array}{r}1.0 \\
1.0 \\
1550 \\
85 \\
10\end{array}$ & $\begin{array}{l}.30 \\
.51 \\
.75 \\
.63 \\
.40\end{array}$ & $\begin{array}{l}.00 \\
.00 \\
.00 \\
.00 \\
.00\end{array}$ & $\begin{array}{l}.00 \\
.00 \\
.00 \\
.00 \\
.00\end{array}$ & $\begin{array}{l}.00 \\
.00 \\
.00 \\
.00 \\
.00\end{array}$ \\
\hline $\begin{array}{l}16 \\
17 \\
18 \\
19 \\
20\end{array}$ & $\begin{array}{r}227 \\
405 \\
395 \\
115 \\
29\end{array}$ & $\begin{array}{l}1.8 \\
1.5 \\
1.3 \\
1.0 \\
.90\end{array}$ & $\begin{array}{l}.40 \\
.30 \\
.40 \\
.51 \\
.63\end{array}$ & $\begin{array}{l}.93 \\
.55 \\
.59 \\
.76 \\
.98\end{array}$ & $\begin{array}{l}.68 \\
.82 \\
.77 \\
.75 \\
.79\end{array}$ & $\begin{array}{l}.98 \\
1.0 \\
.76 \\
.65 \\
.67\end{array}$ & $\begin{array}{l}.63 \\
.56 \\
.41 \\
.40 \\
1.4\end{array}$ & $\begin{array}{l}6.4 \\
4.7 \\
3.2 \\
3.1 \\
3.4\end{array}$ & $\begin{array}{l}.63 \\
.63 \\
.51 \\
.51 \\
.40\end{array}$ & $\begin{array}{l}.00 \\
.00 \\
.00 \\
.00 \\
.00\end{array}$ & $\begin{array}{l}.00 \\
.00 \\
.00 \\
.00 \\
.00\end{array}$ & $\begin{array}{l}.00 \\
.00 \\
.00 \\
.00 \\
.00\end{array}$ \\
\hline $\begin{array}{l}21 \\
22 \\
23 \\
24 \\
25\end{array}$ & $\begin{array}{l}2.5 \\
1.7 \\
1.3 \\
1.2 \\
.99\end{array}$ & $\begin{array}{l}.90 \\
.90 \\
1.0 \\
.90 \\
.90\end{array}$ & $\begin{array}{l}.40 \\
.30 \\
.30 \\
.40 \\
.51\end{array}$ & $\begin{array}{l}1.2 \\
1.2 \\
.99 \\
.66 \\
.63\end{array}$ & $\begin{array}{l}.97 \\
1.0 \\
.97 \\
1.1 \\
.77\end{array}$ & $\begin{array}{l}.75 \\
.75 \\
.86 \\
1.1 \\
1.2\end{array}$ & $\begin{array}{l}2.5 \\
13 \\
16 \\
7.3 \\
7.4\end{array}$ & $\begin{array}{l}4.6 \\
3.8 \\
2.3 \\
4.9 \\
3.8\end{array}$ & $\begin{array}{l}.40 \\
.40 \\
.22 \\
.22 \\
.14\end{array}$ & $\begin{array}{l}.00 \\
.00 \\
.00 \\
.00 \\
.00\end{array}$ & $\begin{array}{l}.00 \\
.00 \\
.00 \\
.00 \\
.00\end{array}$ & $\begin{array}{l}.00 \\
.00 \\
.00 \\
.00 \\
.00\end{array}$ \\
\hline $\begin{array}{l}26 \\
27 \\
28 \\
29 \\
30 \\
31\end{array}$ & $\begin{array}{r}.87 \\
.87 \\
.84 \\
.72 \\
.67\end{array}$ & $\begin{array}{l}.63 \\
.51 \\
.51 \\
.75 \\
.90 \\
. .-\end{array}$ & $\begin{array}{l}.63 \\
.58 \\
.56 \\
.64 \\
.75 \\
.75\end{array}$ & $\begin{array}{l}.63 \\
.68 \\
.81 \\
.89 \\
1.2 \\
1.4\end{array}$ & $\begin{array}{l}.97 \\
1.0 \\
.90 \\
--- \\
--- \\
---\end{array}$ & $\begin{array}{l}.92 \\
1.4 \\
1.8 \\
1.4 \\
1.3 \\
1.3\end{array}$ & $\begin{array}{l}4.5 \\
2.9 \\
2.2 \\
1.8 \\
1.7 \\
---\end{array}$ & $\begin{array}{l}2.8 \\
2.1 \\
1.6 \\
1.2 \\
.80 \\
.75\end{array}$ & $\begin{array}{l}.14 \\
.14 \\
.03 \\
.03 \\
.30 \\
.--\end{array}$ & $\begin{array}{l}.00 \\
.00 \\
.00 \\
.00 \\
.00 \\
.00\end{array}$ & $\begin{array}{l}.00 \\
.00 \\
.00 \\
.00 \\
.00 \\
.00\end{array}$ & $\begin{array}{l}.00 \\
.00 \\
.00 \\
.00 \\
.00 \\
. .-\end{array}$ \\
\hline $\begin{array}{l}\text { TOTAL } \\
\text { MEAN } \\
\text { MAX } \\
\text { MIN } \\
\text { CFSM } \\
\text { IN. } \\
\text { AC-FT } \\
(\dagger \dagger)\end{array}$ & $\begin{array}{r}1381.66 \\
44.6 \\
405 \\
.00 \\
1.15 \\
1.33 \\
2740 \\
-\end{array}$ & $\begin{array}{r}1513.70 \\
50.5 \\
459 \\
.51 \\
1.31 \\
1.45 \\
3000 \\
-\end{array}$ & $\begin{array}{r}23.25 \\
.75 \\
1.4 \\
.30 \\
.02 \\
.02 \\
46 \\
.54\end{array}$ & $\begin{array}{r}28.27 \\
.91 \\
1.4 \\
.55 \\
.02 \\
.03 \\
56 \\
.63\end{array}$ & $\begin{array}{r}23.09 \\
.82 \\
1.1 \\
.51 \\
.02 \\
.02 \\
46 \\
.72\end{array}$ & $\begin{array}{r}29.96 \\
.97 \\
1.8 \\
.63 \\
.03 \\
.03 \\
59 \\
1.53\end{array}$ & $\begin{array}{r}74.33 \\
2.48 \\
16 \\
.40 \\
.06 \\
.07 \\
147 \\
3.05\end{array}$ & $\begin{array}{r}1711.05 \\
55.2 \\
1550 \\
.75 \\
1.43 \\
1.64 \\
3390 \\
6.35\end{array}$ & $\begin{array}{r}15.09 \\
.50 \\
1.2 \\
.03 \\
.01 \\
.01 \\
30 \\
2.65\end{array}$ & $\begin{array}{r}3.04 \\
.098 \\
1.5 \\
.00 \\
.003 \\
.00 \\
6.0 \\
.07\end{array}$ & $\begin{array}{l}.00 \\
.000 \\
.00 \\
.00 \\
.000 \\
.00 \\
.00 \\
1.18\end{array}$ & $\begin{array}{r}.00 \\
.000 \\
.00 \\
.00 \\
.000 \\
.00 \\
.00 \\
2.93\end{array}$ \\
\hline
\end{tabular}

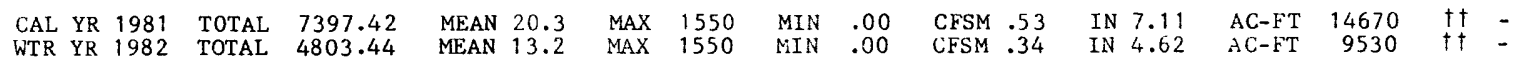

tt Weighted-mean rainfall, in inches. 
08159170 BIG SANDY CREEK NEAR ELCIN, TX

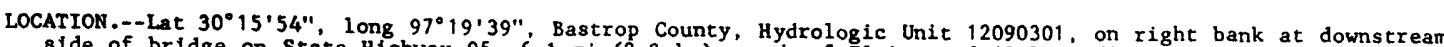
side of bridge on State Highway $95,6.1 \mathrm{mi}(9.8 \mathrm{~km})$ south of Elgin, and $10.7 \mathrm{mi}(17.2 \mathrm{~km})$ north of Bastrop. DRAINAGE AREA.--63.8 $\mathrm{mL}^{2}\left(165.2 \mathrm{~km}^{2}\right)$.

\section{WATER - DISCHARGE RECORDS}

PERIOD OF RECORD.--July 1979 to current year.

GAGE.--Water-stage recorder. Altitude of gage is $392 \mathrm{ft}(119.5 \mathrm{~m})$, from topographic map.

REMARRS.- Water-discharge records fair. No known regulation or diversion. Station is part of hydrologic-research profect to study effects of lignite strip mining on local water resources. Station has automatic water-quality
sampler. Three recording rain gages are located in the watershed. EXTREMES FOR PERIOD OF RECORD.--Maximum discharge, $1,720 \mathrm{ft}^{3} / \mathrm{s}\left(48.7 \mathrm{~m}^{3} / \mathrm{s}\right)$ May 14,1980 , gage height, $15.78 \mathrm{ft}$
$(4.810 \mathrm{~m})$; no flow July 30 to Sept. 6. Sept. $8-29,1980$. EXTREMES FOR PERIOD JULY TO SEPTEMBER $1979 .-$ Maximum discharge, $256 \mathrm{ft}^{3} / \mathrm{s}\left(7.25 \mathrm{~m}^{3} / \mathrm{s}\right) \mathrm{July} 28, \mathrm{gage} \mathrm{height,} 8.81$
$\mathrm{ft}(2.685 \mathrm{~m})$, no peak above base of $500 \mathrm{ft} / \mathrm{s}\left(14.2 \mathrm{~m}^{3} / \mathrm{s}\right) ; \mathrm{minimum}, 0.05 \mathrm{ft} / \mathrm{s}(0.001 \mathrm{~m} / \mathrm{s}) \mathrm{Sept}$. 16,17 . EXTREMES FOR CURRENT YEAR.--Peak discharges above base of $500 \mathrm{ft}^{3} / \mathrm{s}\left(14.2 \mathrm{~m}^{3} / \mathrm{s}\right)$ and maximum (*):

\begin{tabular}{|c|c|c|c|c|c|}
\hline Date & Time & $\begin{array}{c}\text { Disch } \\
\left(\mathrm{ft}^{3} / \mathrm{s}\right)\end{array}$ & $\mathrm{(m}^{\mathrm{rg} / \mathrm{s})}$ & $\begin{array}{l}\text { Gage } \\
(\mathrm{ft})\end{array}$ & $\begin{array}{r}\text { height } \\
\text { (m) }\end{array}$ \\
\hline $\begin{array}{ll}\text { Mar. } & 28 \\
\text { May } 14\end{array}$ & $\begin{array}{l}0215 \\
0615\end{array}$ & $\begin{array}{r}1,340 \\
* 1,720\end{array}$ & $\begin{array}{l}37.9 \\
48.7\end{array}$ & $\begin{array}{l}14.51 \\
15.78\end{array}$ & 4.81 \\
\hline
\end{tabular}

Minimum discharge, no flow July 30 to Sept. 6, Sept. 8-29.

DISCHARGE, IN CUBIC FEET PER SECOND, JULY TO SEPTEMBER 1979

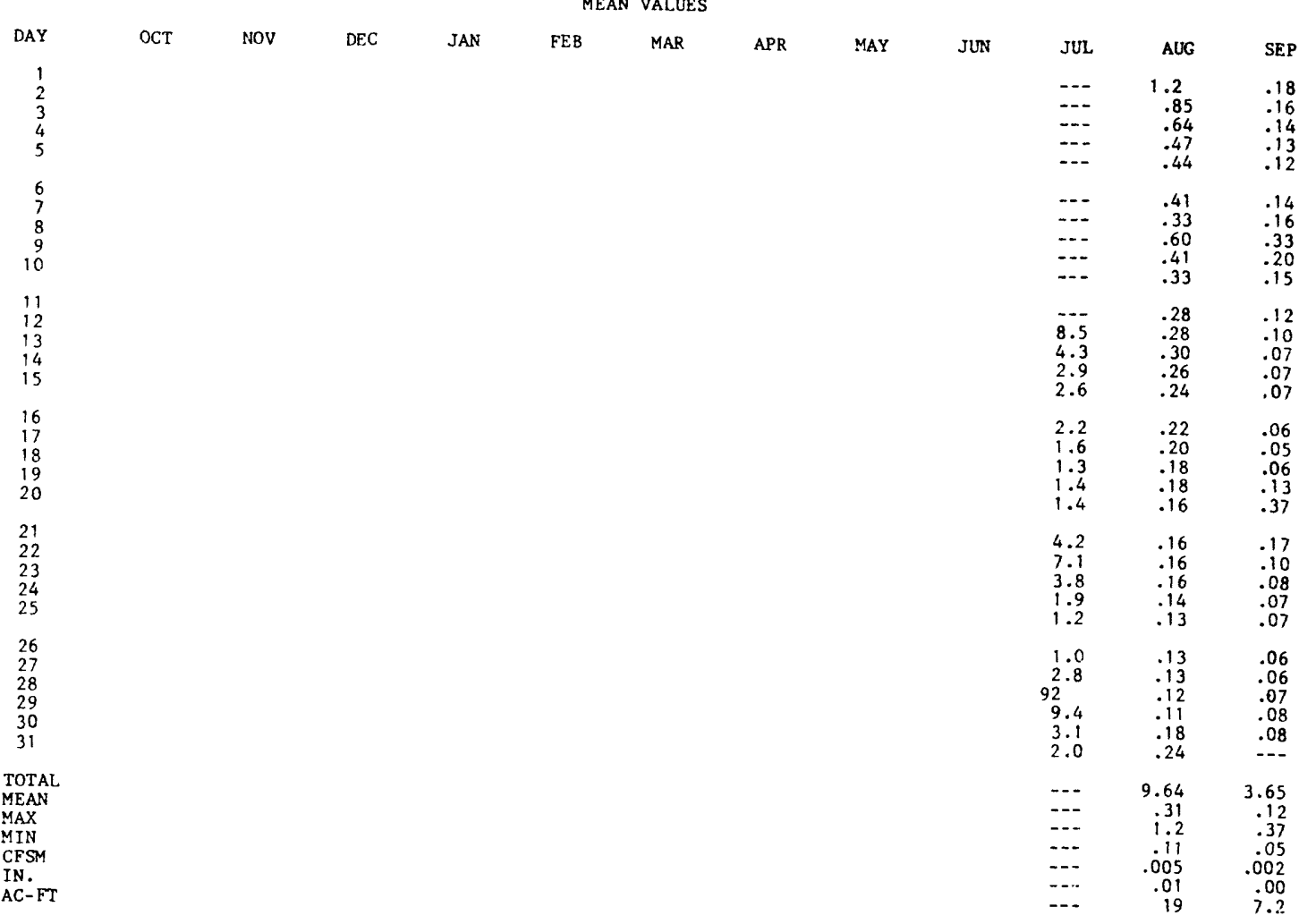

WTR YR 1979 TOTAL - MEAN - MAX - MIN - CFSM - IN. - AC-FT - 
10.0 SUPPLEMENTAL DATA--Continued

10.2 Daily-Mean Discharge for Gaging Stations: Big Sandy Creek near

McDade and Big Sandy Creek near Elgin--Continued

COLORADO RIVER BSIN

08159170 BIG SANDY CREEK NEAR ELGIN, TX--Continued

DISCHARGE, IN CUBIC FEET PER SECOND, WATER YEAR OCTOBER 1979 TO SEPTEMBER 1980

\begin{tabular}{|c|c|c|c|c|c|c|c|c|c|c|c|c|}
\hline DAY & $O C T$ & Nov & $D E C$ & JAN & FEB & MAR & $\mathrm{APR}$ & MAY & JUN & JUL & AUG & SEP \\
\hline $\begin{array}{l}1 \\
2 \\
3 \\
4 \\
5\end{array}$ & $\begin{array}{l}.08 \\
.08 \\
.07 \\
.25 \\
.07\end{array}$ & $\begin{array}{l}.05 \\
.03 \\
.02 \\
.02 \\
.03\end{array}$ & $\begin{array}{l}.10 \\
.11 \\
.16 \\
.16 \\
.18\end{array}$ & $\begin{array}{l}1.8 \\
1.5 \\
1.3 \\
.88 \\
.85\end{array}$ & $\begin{array}{l}2.6 \\
2.5 \\
2.4 \\
2.0 \\
1.8\end{array}$ & $\begin{array}{l}6.1 \\
7.6 \\
3.7 \\
2.6 \\
2.1\end{array}$ & $\begin{array}{l}8.5 \\
7.3 \\
6.5 \\
5.5 \\
4.7\end{array}$ & $\begin{array}{r}8.9 \\
11 \\
4.9 \\
2.9 \\
2.1\end{array}$ & $\begin{array}{l}2.3 \\
2.0 \\
1.7 \\
1.5 \\
1.3\end{array}$ & $\begin{array}{l}.22 \\
.24 \\
.24 \\
.26 \\
.24\end{array}$ & $\begin{array}{l}.00 \\
.00 \\
.00 \\
.00 \\
.00\end{array}$ & $\begin{array}{l}.00 \\
.00 \\
.00 \\
.00 \\
.00\end{array}$ \\
\hline $\begin{array}{r}6 \\
7 \\
8 \\
9 \\
10\end{array}$ & $\begin{array}{l}.07 \\
.06 \\
.06 \\
.05 \\
.06\end{array}$ & $\begin{array}{l}.03 \\
.04 \\
.03 \\
.06 \\
.06\end{array}$ & $\begin{array}{l}.22 \\
.20 \\
.23 \\
.25 \\
.26\end{array}$ & $\begin{array}{l}.93 \\
.74 \\
.73 \\
.69 \\
.77\end{array}$ & $\begin{array}{l}1.7 \\
1.5 \\
1.7 \\
2.4 \\
3.9\end{array}$ & $\begin{array}{l}1.8 \\
1.5 \\
1.4 \\
1.3 \\
1.1\end{array}$ & $\begin{array}{l}3.9 \\
3.8 \\
3.3 \\
2.7 \\
2.4\end{array}$ & $\begin{array}{l}1.5 \\
1.7 \\
2.7 \\
9.2 \\
5.6\end{array}$ & $\begin{array}{l}1.2 \\
1.1 \\
1.1 \\
1.1 \\
1.0\end{array}$ & $\begin{array}{l}.24 \\
.24 \\
.23 \\
.24 \\
.24\end{array}$ & $\begin{array}{l}.00 \\
.00 \\
.00 \\
.00 \\
.00\end{array}$ & $\begin{array}{l}.00 \\
.10 \\
.00 \\
.00 \\
.00\end{array}$ \\
\hline $\begin{array}{l}11 \\
12 \\
13 \\
14 \\
15\end{array}$ & $\begin{array}{l}.06 \\
.05 \\
.05 \\
.04 \\
.05\end{array}$ & $\begin{array}{l}.07 \\
.06 \\
.06 \\
.06 \\
.07\end{array}$ & $\begin{array}{l}.28 \\
.38 \\
.36 \\
.25 \\
.25\end{array}$ & $\begin{array}{l}.77 \\
.74 \\
.74 \\
.75 \\
.83\end{array}$ & $\begin{array}{l}2.6 \\
2.0 \\
1.9 \\
2.3 \\
1.9\end{array}$ & $\begin{array}{l}.92 \\
1.2 \\
.98 \\
.88 \\
.80\end{array}$ & $\begin{array}{l}2.4 \\
2.1 \\
3.9 \\
4.4 \\
3.0\end{array}$ & $\begin{array}{c}3.2 \\
8.3 \\
205 \\
1000 \\
184\end{array}$ & $\begin{array}{l}1.0 \\
.96 \\
.86 \\
.71 \\
.66\end{array}$ & $\begin{array}{l}.23 \\
.22 \\
.22 \\
.22 \\
.22\end{array}$ & $\begin{array}{l}.00 \\
.00 \\
.00 \\
.00 \\
.00\end{array}$ & $\begin{array}{l}.00 \\
.00 \\
.00 \\
.00 \\
.00\end{array}$ \\
\hline $\begin{array}{l}16 \\
17 \\
18 \\
19 \\
20\end{array}$ & $\begin{array}{l}.07 \\
.05 \\
.06 \\
.05 \\
.05\end{array}$ & $\begin{array}{l}.08 \\
.10 \\
.13 \\
.14 \\
.13\end{array}$ & $\begin{array}{l}.36 \\
.26 \\
.20 \\
.20 \\
.16\end{array}$ & $\begin{array}{l}.87 \\
1.92 \\
1.0 \\
14\end{array}$ & $\begin{array}{c}5.1 \\
10 \\
6.4 \\
4.5 \\
3.3\end{array}$ & $\begin{array}{l}.75 \\
.77 \\
.75 \\
.76 \\
.84\end{array}$ & $\begin{array}{l}2.3 \\
1.9 \\
1.7 \\
1.5 \\
1.4\end{array}$ & $\begin{array}{r}142 \\
37 \\
16 \\
11 \\
10\end{array}$ & $\begin{array}{l}.53 \\
.42 \\
.38 \\
.35 \\
.32\end{array}$ & $\begin{array}{l}.21 \\
.18 \\
.17 \\
.16 \\
.15\end{array}$ & $\begin{array}{l}.00 \\
.00 \\
.00 \\
.00 \\
.00\end{array}$ & $\begin{array}{l}.00 \\
.00 \\
.00 \\
.00 \\
.00\end{array}$ \\
\hline $\begin{array}{l}21 \\
22 \\
23 \\
24 \\
25\end{array}$ & $\begin{array}{l}.05 \\
.06 \\
.06 \\
.06 \\
.07\end{array}$ & $\begin{array}{l}.27 \\
.22 \\
.14 \\
.11 \\
.12\end{array}$ & $\begin{array}{l}.16 \\
.14 \\
.33 \\
.55 \\
.36\end{array}$ & $\begin{array}{c}13 \\
63 \\
35 \\
11 \\
6.5\end{array}$ & $\begin{array}{l}2.8 \\
2.7 \\
1.9 \\
1.6 \\
1.3\end{array}$ & $\begin{array}{l}.79 \\
.75 \\
.77 \\
.67 \\
.76\end{array}$ & $\begin{array}{r}1.2 \\
1.1 \\
1.1 \\
1.1 \\
13\end{array}$ & $\begin{array}{l}7.8 \\
6.0 \\
4.8 \\
4.1 \\
3.8\end{array}$ & $\begin{array}{l}.33 \\
.31 \\
.30 \\
.28 \\
.25\end{array}$ & $\begin{array}{l}.15 \\
.14 \\
.13 \\
.12 \\
.10\end{array}$ & $\begin{array}{l}.00 \\
.00 \\
.00 \\
.00 \\
.00\end{array}$ & $\begin{array}{l}.00 \\
.00 \\
.00 \\
.00 \\
.00\end{array}$ \\
\hline $\begin{array}{l}26 \\
27 \\
28 \\
29 \\
30 \\
31\end{array}$ & $\begin{array}{l}.08 \\
.09 \\
.09 \\
.07 \\
.25 \\
.33\end{array}$ & $\begin{array}{l}.13 \\
.11 \\
.09 \\
.08 \\
.08 \\
. .\end{array}$ & $\begin{array}{r}.18 \\
.31 \\
.22 \\
13 \\
6.7 \\
2.9\end{array}$ & $\begin{array}{l}4.9 \\
3.8 \\
3.3 \\
3.1 \\
3.0 \\
2.9\end{array}$ & $\begin{array}{l}1.2 \\
1.1 \\
1.5 \\
1.7 \\
-. \\
-.\end{array}$ & $\begin{array}{c}1.0 \\
216 \\
488 \\
22 \\
11 \\
8.8\end{array}$ & $\begin{array}{r}14 \\
6.0 \\
3.4 \\
2.2 \\
1.8 \\
-\end{array}$ & $\begin{array}{l}3.3 \\
3.0 \\
2.7 \\
2.5 \\
2.3 \\
2.3\end{array}$ & $\begin{array}{l}.22 \\
.24 \\
.23 \\
.22 \\
.24 \\
-.-\end{array}$ & $\begin{array}{l}.08 \\
.06 \\
.04 \\
.02 \\
.00 \\
.00\end{array}$ & $\begin{array}{l}.00 \\
.00 \\
.00 \\
.00 \\
.00 \\
.00\end{array}$ & $\begin{array}{l}.00 \\
.00 \\
.00 \\
.00 \\
.11 \\
-. .\end{array}$ \\
\hline $\begin{array}{l}\text { TOTAL } \\
\text { MEAN } \\
\text { MAX } \\
\text { MIN } \\
\text { CFSM } \\
\text { IN. } \\
\text { AC-FT } \\
(+t)\end{array}$ & $\begin{array}{r}2.59 \\
.084 \\
.33 \\
.04 \\
.001 \\
.00 \\
5.1 \\
1.61\end{array}$ & $\begin{array}{r}2.62 \\
.087 \\
.27 \\
.02 \\
.001 \\
.00 \\
5.2 \\
.80\end{array}$ & $\begin{array}{r}29.22 \\
.94 \\
13 \\
.10 \\
.02 \\
.02 \\
58 \\
3.18\end{array}$ & $\begin{array}{r}181.41 \\
5.85 \\
63 \\
.69 \\
.09 \\
.11 \\
360 \\
2.75\end{array}$ & $\begin{array}{r}78.3 \\
2.70 \\
10 \\
1.1 \\
.04 \\
.05 \\
155 \\
2.13\end{array}$ & $\begin{array}{r}788.39 \\
25.4 \\
488 \\
.67 \\
.40 \\
.46 \\
1550 \\
3.62\end{array}$ & $\begin{array}{r}118.2 \\
3.94 \\
14 \\
1.1 \\
.06 \\
.07 \\
234 \\
2.27\end{array}$ & $\begin{array}{r}1709.6 \\
55.1 \\
1000 \\
1.5 \\
.86 \\
1.00 \\
3390 \\
6.85\end{array}$ & $\begin{array}{r}23.11 \\
.77 \\
2.3 \\
.22 \\
.01 \\
.01 \\
46 \\
.58\end{array}$ & $\begin{array}{r}5.21 \\
.17 \\
.26 \\
.00 \\
.003 \\
.00 \\
10 \\
.33\end{array}$ & $\begin{array}{r}.00 \\
.000 \\
.00 \\
.00 \\
.000 \\
.00 \\
.00 \\
.80\end{array}$ & $\begin{array}{r}.21 \\
.007 \\
.11 \\
.00 \\
.000 \\
.00 \\
.44 \\
2.74\end{array}$ \\
\hline
\end{tabular}

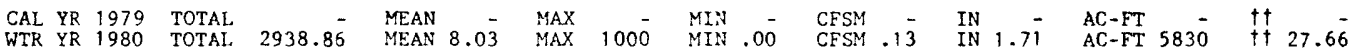

t† Weighted-mean rainfall, in inches, based on three rain gages. 
COLORADO RIVER BASIN

08159170 BIG SANDY CREEK NEAR ELGIN, TX

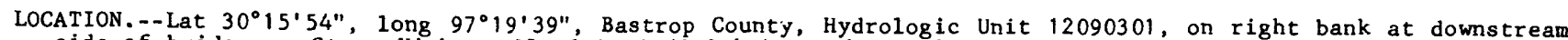
side of bridge on State Highway $95,6.1 \mathrm{mi}(9.8 \mathrm{~km})$ south of Elgin, and $10.7 \mathrm{mi}(17.2 \mathrm{~km})$ north of Bastrop. DRAINAGE AREA. $--63.8 \mathrm{mi}^{2}\left(165.2 \mathrm{~km}^{2}\right)$.

\section{WATER-DISCHARGE RECORDS}

PERIOD OF RECORD.--July 1979 to current year.

GAGE.--Water-stage recorder. Altitude of gage is $392 \mathrm{ft}(119.5 \mathrm{~m})$, from topographic map.

REMARKS. --Water-discharge records fair. No known regulation or diversion. Station is part of hydrologic-research project to study effects of lignite strip mining on local water resources. Station has automatic water-quality
sampler. Three recording rain gages are located in the watershed.

EXTREMES FOR PERIOD OF RECORD.--Maximum discharge, $5,760 \mathrm{ft}^{3} / \mathrm{s}\left(163 \mathrm{~m}^{3} / \mathrm{s}\right)$ June 11,1981 , gage height, $21.54 \mathrm{ft}$ $(6.565 \mathrm{~m})$; no flow for several days each year.

EXTREMES FOR CURRENT YEAR.--Peak discharges above base of $500 \mathrm{ft}^{3} / \mathrm{s}\left(14.2 \mathrm{~m}^{3} / \mathrm{s}\right)$ and maximum (*):

\begin{tabular}{|c|c|c|c|c|c|}
\hline Date & Time & $\begin{array}{r}\text { Dis } \\
\left(\mathrm{ft}^{3} / \mathrm{s}\right.\end{array}$ & $\left(\mathrm{m}^{3} / \mathrm{s}\right)$ & $\begin{array}{c}\text { Gage } \\
(\mathrm{ft})\end{array}$ & $\begin{array}{r}\text { height } \\
\text { (m) }\end{array}$ \\
\hline $\begin{array}{ll}\text { June } & 11 \\
\text { June } 13 \\
\text { June } 16\end{array}$ & $\begin{array}{l}1100 \\
2345 \\
1900\end{array}$ & $\begin{array}{r}* 5,760 \\
2,400 \\
1,940\end{array}$ & $\begin{array}{c}163 \\
68.0 \\
54.9\end{array}$ & $\begin{array}{l}21.54 \\
17.32 \\
16.36\end{array}$ & \\
\hline
\end{tabular}

Minimum discharge, no flow Oct. 7-17.

DISCHARGE, IN CUBIC FEET PER SECOND, WATER YEAR OCTOBER 1980 TO SEPTEMBER 1981 MEAN VALUES

\begin{tabular}{|c|c|c|c|c|c|c|c|c|c|c|c|c|}
\hline DAY & OCT & NOV & $D E C$ & JAN & FEB & MAR & APR & MAY & JUN & JUL & AUG & SEP \\
\hline $\begin{array}{l}1 \\
2 \\
3 \\
4 \\
5\end{array}$ & $\begin{array}{l}.10 \\
.08 \\
.07 \\
.05 \\
.03\end{array}$ & $\begin{array}{l}.18 \\
.18 \\
.18 \\
.20 \\
.20\end{array}$ & $\begin{array}{l}.26 \\
.26 \\
.26 \\
.26 \\
.26\end{array}$ & $\begin{array}{l}.38 \\
.33 \\
.30 \\
.30 \\
.33\end{array}$ & $\begin{array}{l}.42 \\
.41 \\
.38 \\
.39 \\
.59\end{array}$ & $\begin{array}{r}.41 \\
.44 \\
19^{.43} \\
8.5\end{array}$ & $\begin{array}{l}.64 \\
.41 \\
.39 \\
.30 \\
.23\end{array}$ & $\begin{array}{l}.24 \\
.20 \\
.23 \\
.25 \\
.19\end{array}$ & $\begin{array}{r}30 \\
125 \\
12 \\
14 \\
49\end{array}$ & $\begin{array}{l}1.3 \\
1.2 \\
1.0 \\
1.1 \\
8.0\end{array}$ & $\begin{array}{l}.11 \\
.10 \\
.09 \\
.08 \\
.08\end{array}$ & $\begin{array}{l}.09 \\
.09 \\
.09 \\
.15 \\
.10\end{array}$ \\
\hline $\begin{array}{r}6 \\
7 \\
8 \\
9 \\
10\end{array}$ & $\begin{array}{l}.01 \\
.00 \\
.00 \\
.00 \\
.00\end{array}$ & $\begin{array}{l}.20 \\
.24 \\
.28 \\
.33 \\
.38\end{array}$ & $\begin{array}{l}.30 \\
.30 \\
.30 \\
.36 \\
.38\end{array}$ & $\begin{array}{l}.36 \\
.38 \\
.38 \\
.44 \\
.38\end{array}$ & $\begin{array}{l}.73 \\
.56 \\
.42 \\
.39 \\
.59\end{array}$ & $\begin{array}{c}2.2 \\
1.0 \\
.74 \\
.51 \\
.36\end{array}$ & $\begin{array}{l}.25 \\
.26 \\
.24 \\
.25 \\
.27\end{array}$ & $\begin{array}{l}.16 \\
.14 \\
.13 \\
.12 \\
.12\end{array}$ & $\begin{array}{l}30 \\
6.6 \\
3.2 \\
1.9 \\
1.4\end{array}$ & $\begin{array}{l}15 \\
6.1 \\
3.2 \\
2.1 \\
1.7\end{array}$ & $\begin{array}{l}.08 \\
.07 \\
.06 \\
.05 \\
.05\end{array}$ & $\begin{array}{l}.07 \\
.06 \\
.06 \\
.06 \\
.05\end{array}$ \\
\hline $\begin{array}{l}11 \\
12 \\
13 \\
14 \\
15\end{array}$ & $\begin{array}{l}.00 \\
.00 \\
.00 \\
.00 \\
.00\end{array}$ & $\begin{array}{l}.33 \\
.30 \\
.30 \\
.30 \\
.30\end{array}$ & $\begin{array}{l}.33 \\
.28 \\
.28 \\
.30 \\
.36\end{array}$ & $\begin{array}{l}.36 \\
.30 \\
.28 \\
.33 \\
.33\end{array}$ & $\begin{array}{l}.43 \\
.32 \\
.30 \\
.28 \\
.30\end{array}$ & $\begin{array}{l}.33 \\
.34 \\
.35 \\
.37 \\
.38\end{array}$ & $\begin{array}{l}.22 \\
.19 \\
.20 \\
.18 \\
.15\end{array}$ & $\begin{array}{l}.10 \\
.10 \\
.11 \\
.09 \\
.09\end{array}$ & $\begin{array}{r}2350 \\
413 \\
452 \\
1060 \\
68\end{array}$ & $\begin{array}{c}1.2 \\
.91 \\
.74 \\
.67 \\
.59\end{array}$ & $\begin{array}{l}.05 \\
.05 \\
.05 \\
.05 \\
.05\end{array}$ & $\begin{array}{l}.05 \\
.04 \\
.05 \\
.04 \\
.18\end{array}$ \\
\hline $\begin{array}{l}16 \\
17 \\
18 \\
19 \\
20\end{array}$ & $\begin{array}{l}.00 \\
.00 \\
.11 \\
.11 \\
.09\end{array}$ & $\begin{array}{l}.47 \\
.80 \\
.55 \\
.38 \\
.28\end{array}$ & $\begin{array}{l}.36 \\
.36 \\
.30 \\
.30 \\
.30\end{array}$ & $\begin{array}{r}.30 \\
.30 \\
.26 \\
.97 \\
2.0\end{array}$ & $\begin{array}{l}.33 \\
.34 \\
.33 \\
.30 \\
.30\end{array}$ & $\begin{array}{l}.33 \\
.30 \\
.27 \\
.24 \\
.23\end{array}$ & $\begin{array}{l}.16 \\
.18 \\
.17 \\
.15 \\
.30\end{array}$ & $\begin{array}{l}.37 \\
.23 \\
.13 \\
.11 \\
.09\end{array}$ & $\begin{array}{r}874 \\
339 \\
22 \\
11 \\
6.3\end{array}$ & $\begin{array}{l}.49 \\
.47 \\
.41 \\
.38 \\
.57\end{array}$ & $\begin{array}{l}.04 \\
.04 \\
.05 \\
.05 \\
.05\end{array}$ & $\begin{array}{l}.14 \\
.07 \\
.05 \\
.04 \\
.04\end{array}$ \\
\hline $\begin{array}{l}27 \\
22 \\
23 \\
24 \\
25\end{array}$ & $\begin{array}{l}.09 \\
.09 \\
.09 \\
.18 \\
.22\end{array}$ & $\begin{array}{l}.22 \\
.22 \\
.20 \\
.26 \\
.30\end{array}$ & $\begin{array}{l}.28 \\
.28 \\
.30 \\
.33 \\
.36\end{array}$ & $\begin{array}{l}.80 \\
.60 \\
.51 \\
.51 \\
.47\end{array}$ & $\begin{array}{l}.35 \\
.31 \\
.30 \\
.28 \\
.26\end{array}$ & $\begin{array}{l}.24 \\
.22 \\
.21 \\
.22 \\
.20\end{array}$ & $\begin{array}{l}.33 \\
.12 \\
.25 \\
.25 \\
.20\end{array}$ & $\begin{array}{r}.09 \\
.09 \\
18^{.08} \\
46\end{array}$ & $\begin{array}{l}3.9 \\
3.2 \\
2.4 \\
1.9 \\
5.8\end{array}$ & $\begin{array}{l}.62 \\
.45 \\
.33 \\
.24 \\
.19\end{array}$ & $\begin{array}{l}.05 \\
.05 \\
.05 \\
.05 \\
.05\end{array}$ & $\begin{array}{l}.03 \\
.03 \\
.04 \\
.04 \\
.05\end{array}$ \\
\hline $\begin{array}{l}26 \\
27 \\
28 \\
29 \\
30 \\
31\end{array}$ & $\begin{array}{l}.24 \\
.26 \\
.20 \\
.18 \\
.18 \\
.18\end{array}$ & $\begin{array}{l}.85 \\
.64 \\
.36 \\
.28 \\
.28 \\
-.-\end{array}$ & $\begin{array}{l}.36 \\
.36 \\
.36 \\
.38 \\
.41 \\
.38\end{array}$ & $\begin{array}{l}.47 \\
.47 \\
.44 \\
.38 \\
.39 \\
.41\end{array}$ & $\begin{array}{l}.26 \\
.27 \\
.28 \\
--- \\
--- \\
--\end{array}$ & $\begin{array}{l}.21 \\
.21 \\
.22 \\
2.8 \\
4.8 \\
1.4\end{array}$ & $\begin{array}{l}.20 \\
.18 \\
.18 \\
.20 \\
.17 \\
-.-\end{array}$ & $\begin{array}{c}16 \\
4.1 \\
1.5 \\
1.3 \\
1.7 \\
117\end{array}$ & $\begin{array}{l}3.2 \\
2.6 \\
2.8 \\
1.4 \\
1.1 \\
-.-\end{array}$ & $\begin{array}{l}.15 \\
.20 \\
.20 \\
.14 \\
.12 \\
.12\end{array}$ & $\begin{array}{l}.05 \\
.05 \\
.05 \\
.05 \\
.06 \\
.07\end{array}$ & $\begin{array}{l}.04 \\
.04 \\
.03 \\
.03 \\
.03 \\
-.-\end{array}$ \\
\hline $\begin{array}{l}\text { TOTAL } \\
\text { MEAN } \\
\text { MAX } \\
\text { MIN } \\
\text { CFSM } \\
\text { IN. } \\
\text { AC-FT } \\
(+t)\end{array}$ & $\begin{array}{r}2.56 \\
.083 \\
.26 \\
.00 \\
.001 \\
.00 \\
5.1 \\
2.21\end{array}$ & $\begin{array}{r}9.99 \\
.33 \\
.85 \\
.18 \\
.005 \\
.01 \\
20 \\
2.80\end{array}$ & $\begin{array}{r}9.91 \\
.32 \\
.41 \\
.26 \\
.005 \\
.01 \\
20 \\
.87\end{array}$ & $\begin{array}{r}14.46 \\
.47 \\
2.0 \\
.26 \\
.007 \\
.01 \\
29 \\
1.94\end{array}$ & $\begin{array}{r}10.42 \\
.37 \\
.73 \\
.26 \\
.006 \\
.01 \\
21 \\
1.02\end{array}$ & $\begin{array}{r}47.46 \\
1.53 \\
19 \\
.20 \\
.02 \\
.03 \\
94 \\
4.00\end{array}$ & $\begin{array}{r}7.22 \\
.24 \\
.64 \\
.12 \\
.004 \\
.00 \\
14 \\
.99\end{array}$ & $\begin{array}{r}209.06 \\
6.74 \\
117 \\
.08 \\
.11 \\
.112 \\
415 \\
7.07\end{array}$ & $\begin{array}{r}5896.7 \\
197 \\
2350 \\
1.1 \\
3.09 \\
3.44 \\
11700 \\
12.47\end{array}$ & $\begin{array}{r}49.89 \\
1.61 \\
15 \\
.12 \\
.03 \\
.03 \\
99 \\
2.29\end{array}$ & $\begin{array}{r}1.83 \\
.059 \\
.11 \\
.04 \\
.001 \\
.00 \\
3.6 \\
2.00\end{array}$ & $\begin{array}{r}1.88 \\
.063 \\
.18 \\
.03 \\
.001 \\
.00 \\
3.7 \\
1.72\end{array}$ \\
\hline
\end{tabular}

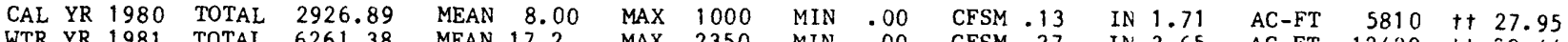

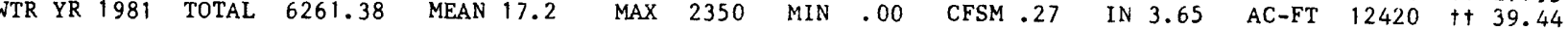

t† Weighted-mean rainfall on watershed, in inches, based on three rain gages. 
10.0 SUPPLEMENTAL DATA--Continued

\subsection{Daily-Mean Discharge for Gaging Stations: Big Sandy Creek near McDade and Big Sandy Creek near Elgin--Continued}

COLORADO RIVFR BASIN

08159170 BIG SANDY CREEK NEAR ELGIN, TX

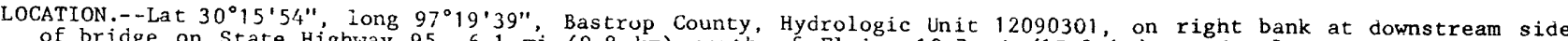
of bridge on State Highway $95,6.1 \mathrm{mi}(9.8 \mathrm{~km})$ south of Elgin, $10.7 \mathrm{mi}(17.2 \mathrm{~km}) \mathrm{north}$ of Bastrop, and $10.8 \mathrm{mi}$

DRAINAGE AREA.$--63.8 \mathrm{mi}^{2}\left(165.2 \mathrm{~km}^{2}\right)$.

WATER-DISCHAKGE RECORDS

PERIOD OF RECORD.--July 1979 to current year.

GAGE.--Water-stage recorder. Al titude of gage is $392 \mathrm{ft}(119.5 \mathrm{~m})$, from topographic map.

REMARKS.--Water-discharge records fair except those for Oct. 1 to Nov. 17 and June 10 to July 26 , which are poor. No known regulation or diversion. Three recording rain gages are located in the watershed. Several observations of water temperature were made during the year.

EXTREMES FOR PERIOD OF RECOKD.- -Maximum discharge, $5,760 \mathrm{ft}^{3} / \mathrm{s}\left(163 \mathrm{~m}^{3} / \mathrm{s}\right)$ June 11, 1981, gage height, $21.54 \mathrm{ft}$ (6.565 $\mathrm{m})$; no flow for several days each year.

EXTREMES FOR CUREENT YEAK.--Maxinum discharge, $5,540 \mathrm{ft}^{3} / \mathrm{s}\left(157 \mathrm{~m}^{3} / \mathrm{s}\right)$ May 13 at $1500 \mathrm{hours}$, gage height, $21.34 \mathrm{ft}$ $(6.504 \mathrm{~m})$, no other peak above base of $500 \mathrm{ft}^{3} / \mathrm{s}\left(14.2 \mathrm{~m}^{3} / \mathrm{s}\right)$; no flow tor many days.

DISCHARTE, IN CUBIC FEET PER SECOND, WATER YEAR OCTOBER 1981 TO SEPTEMBER 1982

\begin{tabular}{|c|c|c|c|c|c|c|c|c|c|c|c|c|}
\hline DAY & $\mathrm{OCT}$ & NOV & $\mathrm{DEC}$ & JAll & FEB & MAR & APR & MAI & JUN & JUL & $A \cup G$ & SEP \\
\hline $\begin{array}{l}1 \\
2 \\
3 \\
4 \\
5\end{array}$ & $\begin{array}{l}.00 \\
.00 \\
.00 \\
.00 \\
.00\end{array}$ & $\begin{array}{c}300 \\
490 \\
340 \\
100 \\
30\end{array}$ & $\begin{array}{l}.80 \\
.91 \\
.74 \\
.64 \\
.64\end{array}$ & $\begin{array}{l}.80 \\
1.1 \\
.97 \\
1.9 \\
.80\end{array}$ & $\begin{array}{l}1.6 \\
1.6 \\
1.6 \\
1.7 \\
1.6\end{array}$ & $\begin{array}{l}1.5 \\
1.4 \\
1.4 \\
1.5 \\
1.4\end{array}$ & $\begin{array}{l}1.3 \\
1.3 \\
1.6 \\
1.4 \\
1.2\end{array}$ & $\begin{array}{l}2.8 \\
5.1 \\
1.6 \\
.55 \\
.38\end{array}$ & $\begin{array}{l}1.5 \\
1.5 \\
1.6 \\
1.6 \\
1.5\end{array}$ & $\begin{array}{l}.55 \\
.51 \\
.47 \\
.41 \\
.41\end{array}$ & $\begin{array}{l}.03 \\
.03 \\
.03 \\
.03 \\
.03\end{array}$ & $\begin{array}{l}.00 \\
.00 \\
.01 \\
.01 \\
.01\end{array}$ \\
\hline $\begin{array}{r}6 \\
7 \\
8 \\
9 \\
10\end{array}$ & $\begin{array}{l}.00 \\
.00 \\
.00 \\
.00 \\
.00\end{array}$ & $\begin{array}{r}5.2 \\
2.3 \\
4.0 \\
90 \\
160\end{array}$ & $\begin{array}{l}.69 \\
.91 \\
1.3 \\
1.3 \\
1.4\end{array}$ & $\begin{array}{l}.74 \\
.64 \\
.51 \\
.60 \\
.74\end{array}$ & $\begin{array}{l}1.4 \\
1.3 \\
1.2 \\
1.2 \\
1.2\end{array}$ & $\begin{array}{l}1.4 \\
1.3 \\
1.3 \\
1.2 \\
1.2\end{array}$ & $\begin{array}{l}.91 \\
.80 \\
.74 \\
.74 \\
.91\end{array}$ & $\begin{array}{l}.64 \\
.80 \\
.69 \\
.44 \\
.33\end{array}$ & $\begin{array}{l}1.6 \\
1.2 \\
1.1 \\
.87 \\
.85\end{array}$ & $\begin{array}{l}.38 \\
.33 \\
.33 \\
.28 \\
.26\end{array}$ & $\begin{array}{l}.03 \\
.03 \\
.03 \\
.02 \\
.02\end{array}$ & $\begin{array}{l}.00 \\
.00 \\
.00 \\
.00 \\
.00\end{array}$ \\
\hline $\begin{array}{l}11 \\
12 \\
13 \\
14 \\
15\end{array}$ & $\begin{array}{r}.00 \\
.00 \\
170\end{array}$ & $\begin{array}{r}96 \\
25 \\
6.0 \\
3.1 \\
2.4\end{array}$ & $\begin{array}{l}1.3 \\
1.2 \\
1.2 \\
.97 \\
.80\end{array}$ & $\begin{array}{l}.47 \\
.80 \\
1.3 \\
1.6 \\
1.8\end{array}$ & $\begin{array}{l}1.2 \\
1.5 \\
1.4 \\
1.3 \\
1.3\end{array}$ & $\begin{array}{l}1.2 \\
1.3 \\
1.7 \\
1.9 \\
1.8\end{array}$ & $\begin{array}{l}.97 \\
.91 \\
.80 \\
.69 \\
.64\end{array}$ & $\begin{array}{r}.24 \\
2180^{.20} \\
356 \\
13\end{array}$ & $\begin{array}{l}.79 \\
.98 \\
.92 \\
.78 \\
.70\end{array}$ & $\begin{array}{l}.24 \\
.24 \\
.20 \\
.20 \\
.16\end{array}$ & $\begin{array}{l}.02 \\
.02 \\
.02 \\
.02 \\
.01\end{array}$ & $\begin{array}{l}.00 \\
.00 \\
.01 \\
.01 \\
.00\end{array}$ \\
\hline $\begin{array}{l}16 \\
17 \\
18 \\
19 \\
20\end{array}$ & $\begin{array}{r}330 \\
450 \\
390 \\
90 \\
38\end{array}$ & $\begin{array}{l}2.0 \\
1.7 \\
1.5 \\
1.3 \\
1.1\end{array}$ & $\begin{array}{r}.91 \\
1.1 \\
.91 \\
.74 \\
.74\end{array}$ & $\begin{array}{l}1.7 \\
1.5 \\
1.5 \\
1.3 \\
1.3\end{array}$ & $\begin{array}{l}1.3 \\
1.2 \\
1.3 \\
1.3 \\
1.4\end{array}$ & $\begin{array}{l}1.6 \\
1.7 \\
1.3 \\
1.5 \\
1.4\end{array}$ & $\begin{array}{l}.55 \\
.51 \\
.44 \\
.44 \\
.64\end{array}$ & $\begin{array}{l}7.3 \\
5.4 \\
3.8 \\
3.4 \\
3.2\end{array}$ & $\begin{array}{l}.74 \\
.69 \\
.69 \\
.69 \\
.69\end{array}$ & $\begin{array}{l}.15 \\
.13 \\
.12 \\
.11 \\
.10\end{array}$ & $\begin{array}{l}.01 \\
.01 \\
.01 \\
.01 \\
.01\end{array}$ & $\begin{array}{l}.01 \\
.02 \\
.01 \\
.01 \\
.02\end{array}$ \\
\hline $\begin{array}{l}21 \\
22 \\
23 \\
24 \\
25\end{array}$ & $\begin{array}{l}5.0 \\
2.3 \\
1.8 \\
1.6 \\
1.4\end{array}$ & $\begin{array}{c}1.1 \\
.97 \\
1.1 \\
.97 \\
.94\end{array}$ & $\begin{array}{l}.74 \\
.97 \\
.91 \\
.74 \\
.64\end{array}$ & $\begin{array}{l}1.5 \\
1.6 \\
1.4 \\
1.3 \\
1.3\end{array}$ & $\begin{array}{l}1.5 \\
1.5 \\
1.4 \\
1.4 \\
1.3\end{array}$ & $\begin{array}{l}1.1 \\
1.1 \\
1.3 \\
1.4 \\
1.4\end{array}$ & $\begin{array}{r}1.5 \\
5.7 \\
19 \\
9.3 \\
8.9\end{array}$ & $\begin{array}{l}3.8 \\
3.6 \\
3.0 \\
4.3 \\
5.6\end{array}$ & $\begin{array}{l}.69 \\
.64 \\
.64 \\
.64 \\
.60\end{array}$ & $\begin{array}{l}.09 \\
.08 \\
.06 \\
.06 \\
.05\end{array}$ & $\begin{array}{l}.01 \\
.01 \\
.00 \\
.00 \\
.00\end{array}$ & $\begin{array}{l}.02 \\
.01 \\
.01 \\
.01 \\
.02\end{array}$ \\
\hline $\begin{array}{l}26 \\
27 \\
28 \\
29 \\
30 \\
31\end{array}$ & $\begin{array}{r}1.3 \\
1.3 \\
1.3 \\
1.2 \\
1.1 \\
30^{\circ}\end{array}$ & $\begin{array}{c}1.0 \\
.99 \\
.89 \\
.90 \\
1.7 \\
-.--\end{array}$ & $\begin{array}{l}.64 \\
.51 \\
.51 \\
.47 \\
.51 \\
.64\end{array}$ & $\begin{array}{l}1.2 \\
1.3 \\
1.2 \\
1.2 \\
1.3 \\
1.5\end{array}$ & $\begin{array}{l}1.3 \\
1.5 \\
1.6 \\
\ldots .- \\
\ldots-\end{array}$ & $\begin{array}{l}1.4 \\
1.6 \\
2.2 \\
2.1 \\
1.7 \\
1.6\end{array}$ & $\begin{array}{l}5.9 \\
3.9 \\
2.4 \\
1.6 \\
1.1 \\
---\end{array}$ & $\begin{array}{l}3.2 \\
2.8 \\
2.4 \\
2.1 \\
1.9 \\
1.7\end{array}$ & $\begin{array}{l}.60 \\
.60 \\
.55 \\
.55 \\
.55 \\
. .-\end{array}$ & $\begin{array}{l}.05 \\
.04 \\
.04 \\
.04 \\
.03 \\
.03\end{array}$ & $\begin{array}{l}.00 \\
.00 \\
.00 \\
.00 \\
.00 \\
.00\end{array}$ & $\begin{array}{l}.02 \\
.02 \\
.02 \\
.02 \\
.02 \\
---\end{array}$ \\
\hline $\begin{array}{l}\text { TOTAL } \\
\text { MEAN } \\
\text { MAX } \\
\text { MIN } \\
\text { CFSM } \\
\text { IN. } \\
\text { AC-FT } \\
(\dagger+)\end{array}$ & $\begin{array}{r}1586.30 \\
5 i .2 \\
450 \\
.00 \\
.80 \\
.92 \\
3150 \\
-\end{array}$ & $\begin{array}{r}1672.16 \\
55.7 \\
490 \\
.89 \\
.87 \\
.97 \\
3320 \\
-\end{array}$ & $\begin{array}{r}26.48 \\
.85 \\
1.4 \\
.47 \\
.01 \\
.02 \\
53 \\
.53\end{array}$ & $\begin{array}{r}36.17 \\
1.17 \\
1.8 \\
.47 \\
.02 \\
.02 \\
72 \\
.82\end{array}$ & $\begin{array}{l}39.1 \\
1.40 \\
1.7 \\
1.2 \\
.02 \\
.02 \\
78 \\
.73\end{array}$ & $\begin{array}{r}45.9 \\
1.48 \\
2.2 \\
1.1 \\
.02 \\
.03 \\
91 \\
1.67\end{array}$ & $\begin{array}{r}76.79 \\
2.56 \\
19 \\
.44 \\
.04 \\
.04 \\
152 \\
2.77\end{array}$ & $\begin{array}{r}2620.27 \\
84.5 \\
2180 \\
.20 \\
1.32 \\
1.53 \\
5200 \\
7.13\end{array}$ & $\begin{array}{r}27.05 \\
.90 \\
1.6 \\
.55 \\
.01 \\
.02 \\
54 \\
2.84\end{array}$ & $\begin{array}{r}6.15 \\
.20 \\
.55 \\
.03 \\
.003 \\
.00 \\
12 \\
.06\end{array}$ & $\begin{array}{r}.44 \\
.014 \\
.03 \\
.00 \\
.000 \\
.00 \\
.9 \\
1.37\end{array}$ & $\begin{array}{r}.20 \\
.010 \\
.02 \\
.00 \\
.000 \\
.00 \\
.6 \\
2.42\end{array}$ \\
\hline
\end{tabular}

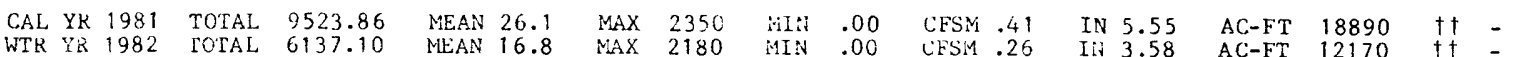

$\dagger$ weighted-mean rainfall, in inches. 
10.3 Water-Quality and Sediment Analysis at Streamflow Sites

COLORADO RIVER BASIN

08159165 BIG SANDY CREEK REAR MCDADE, TX

PERIOD OF RECORD.--Chemical, biochemical, radiochemical, and pesticide anslyses: May to September 1979.

WATER QUALITY DATA, WATER YEAR OCTOBER 1978 TO SEPTEMBER 1979

\begin{tabular}{|c|c|c|c|c|c|c|c|c|c|c|}
\hline DATE & TIME & $\begin{array}{l}\text { STREAM- } \\
\text { FLOW, } \\
\text { INSTAN- } \\
\text { TANEOUS } \\
\text { (CFS) }\end{array}$ & $\begin{array}{l}\text { SPE- } \\
\text { CIFIC } \\
\text { CON- } \\
\text { DUCT- } \\
\text { ANCE } \\
\text { (MICRO- } \\
\text { MHOS) }\end{array}$ & $\begin{array}{c}\text { PH } \\
\text { (UNITS) }\end{array}$ & $\begin{array}{l}\text { TEMPER- } \\
\text { ATURE } \\
\text { (DEG C) }\end{array}$ & $\begin{array}{l}\text { OOLOR } \\
\text { (PLAT- } \\
\text { INUM- } \\
\text { COBALT } \\
\text { UNITS) }\end{array}$ & $\begin{array}{l}\text { TUR- } \\
\text { BID- } \\
\text { ITY } \\
\text { (NTU) }\end{array}$ & $\begin{array}{c}\text { OXYGER, } \\
\text { DIS- } \\
\text { SOLVED } \\
\text { (MG/L) }\end{array}$ & $\begin{array}{c}\text { OXYGEN, } \\
\text { DIS- } \\
\text { SOLVED } \\
\text { (PER- } \\
\text { CENT } \\
\text { SATUR- } \\
\text { ATION) }\end{array}$ & $\begin{array}{c}\text { OXYGEN } \\
\text { DEMAND, } \\
\text { BIO- } \\
\text { CHEM- } \\
\text { ICAL, } \\
5 \text { DAY } \\
\text { (MG/L) }\end{array}$ \\
\hline
\end{tabular}

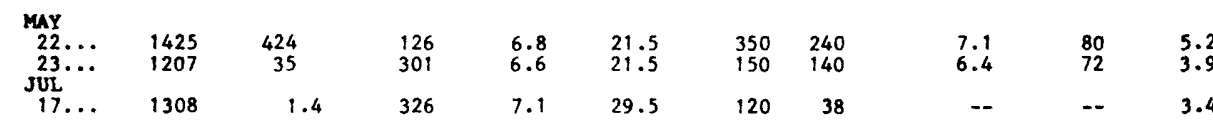

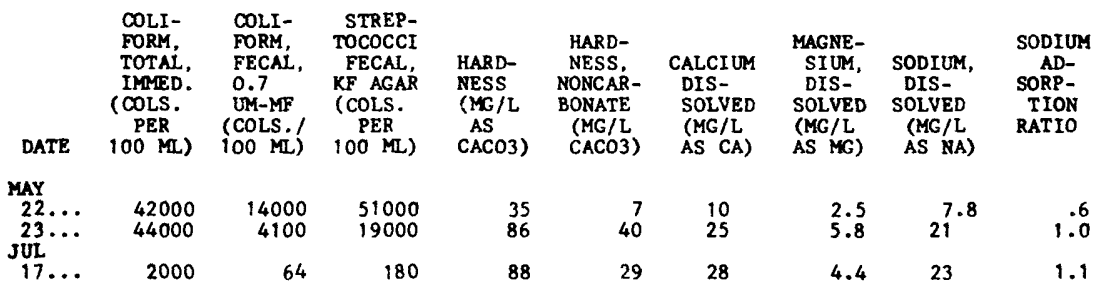

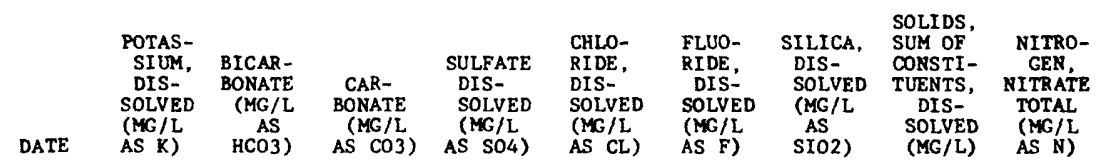

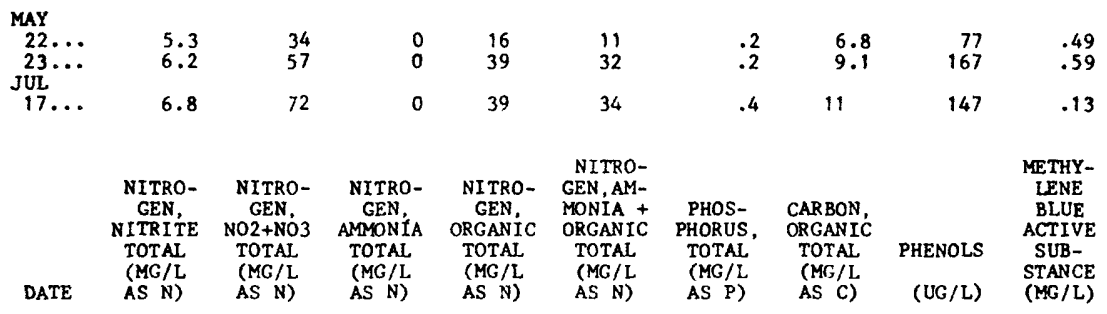

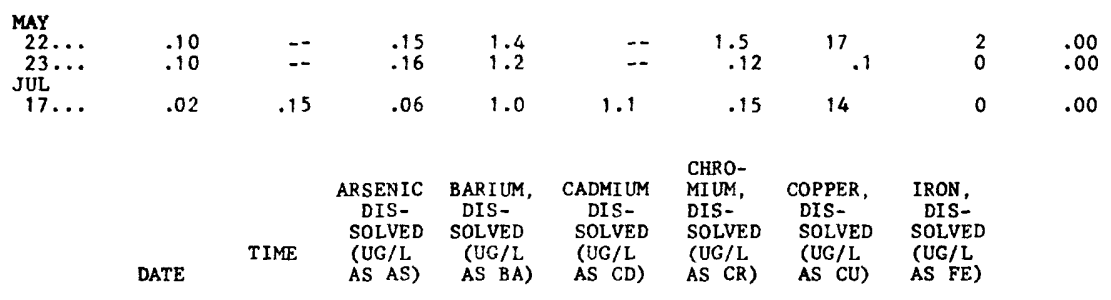

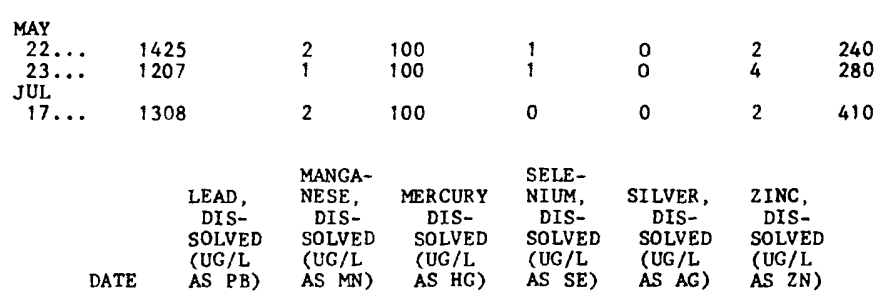

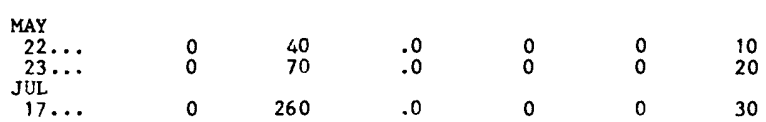


10.0 SUPPLEMENTAL DATA--Cont inued

10.3 Water-Quality and Sediment Analysis at Streamflow Sites--Continued

COLORADO RIVER BASIN

08159165 BIG SANDY CREEK NEAR MCDADE, TX--Continued

WATER QUALITY DATA, WATER YEAR OCTOBER 1978 TO SEPTEMBER 1979

\begin{tabular}{|c|c|c|c|c|c|c|c|c|c|c|c|}
\hline DATE & TIME & $\begin{array}{c}\text { GROSS } \\
\text { ALPHA, } \\
\text { DIS- } \\
\text { SOLVED } \\
\text { (PCI /L } \\
\text { AS } \\
\text { U-NAT) }\end{array}$ & $\begin{array}{c}\text { GROSS } \\
\text { ALPHA, } \\
\text { SUSP. } \\
\text { TOTAL } \\
\text { (PCI/L } \\
\text { AS } \\
\text { U-NAT) }\end{array}$ & $\begin{array}{l}\text { GROSS } \\
\text { ALPHA, } \\
\text { DIS- } \\
\text { SOLVED } \\
\text { (UG/L } \\
\text { AS } \\
\text { U-NAT) }\end{array}$ & $\begin{array}{l}\text { GROSS } \\
\text { ALPHA, } \\
\text { SUSP. } \\
\text { TOTAL } \\
\text { (UG/L } \\
\text { AS } \\
\text { U-NAT) }\end{array}$ & $\begin{array}{l}\text { GROSS } \\
\text { BETA, } \\
\text { DIS- } \\
\text { SOLVED } \\
\text { (PCI/L } \\
\text { AS } \\
\text { CS-137) }\end{array}$ & $\begin{array}{c}\text { GROSS } \\
\text { BETA, } \\
\text { SUSP. } \\
\text { TOTAL } \\
\text { (PCI /L } \\
\text { AS } \\
\text { CS-137) }\end{array}$ & $\begin{array}{l}\text { GROSS } \\
\text { BETA, } \\
\text { DIS- } \\
\text { SOLVED } \\
\text { (PCI/L } \\
\text { AS SR/ } \\
\text { YT-90) }\end{array}$ & $\begin{array}{l}\text { GROSS } \\
\text { BETA, } \\
\text { SUSP. } \\
\text { TOTAL } \\
\text { (PCI/L } \\
\text { AS SR/ } \\
\text { YT }-90 \text { ) }\end{array}$ & $\begin{array}{c}\text { RADIUM } \\
226, \\
\text { DIS- } \\
\text { SOLVED, } \\
\text { RADON } \\
\text { METHOD } \\
\text { (PCI/L) }\end{array}$ & $\begin{array}{l}\text { URANIUM } \\
\text { DIS- } \\
\text { SOLVED, } \\
\text { EXTRAC- } \\
\text { TION } \\
\text { (UG/L) }\end{array}$ \\
\hline
\end{tabular}

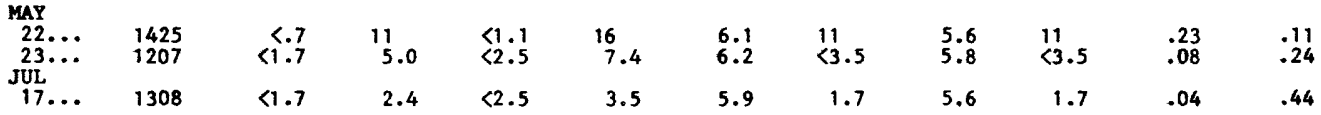

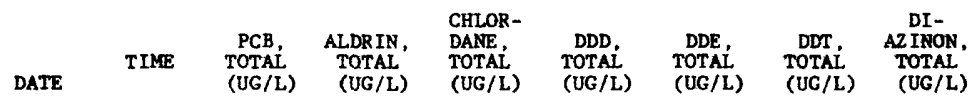

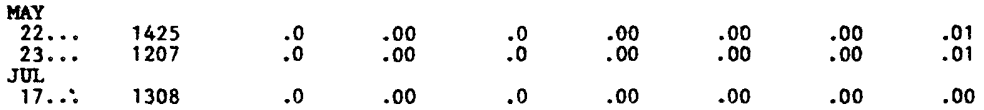

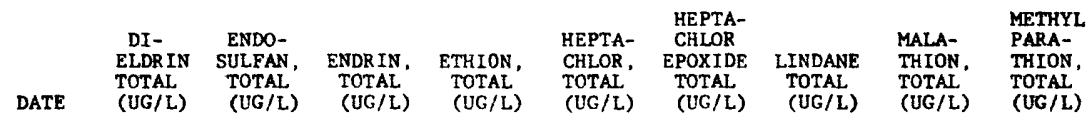

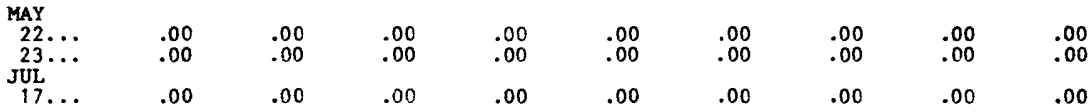

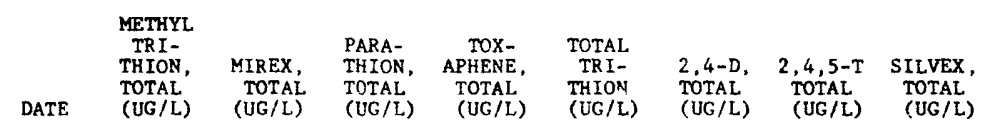

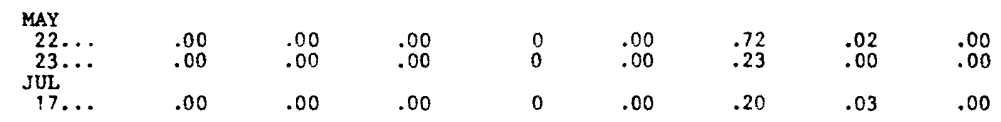


COLORADO RIVER BASIN

$08 \$ 59165$ BIG SANDY CREEK NEAR MCDADE, TX--Continued

WATER-QUALITY RECORDS

PERIOD OF RECORD.--Chemical, biochemical, and pesticide analyses: May 1979 to current year. Radiochemical analyses. May to September 1979.

WATER QUALITY DATA, WATER YEAR OCTOBER 1979 TO SCPTEMBER 1980

\begin{tabular}{|c|c|c|c|c|c|c|c|c|c|c|}
\hline DATE & TIME & $\begin{array}{l}\text { STREAM- } \\
\text { FLOW, } \\
\text { INSTAN- } \\
\text { TANEOUS } \\
\text { (CFS) }\end{array}$ & $\begin{array}{l}\text { SPE- } \\
\text { CIFIC } \\
\text { CON- } \\
\text { DUCT- } \\
\text { ANCE } \\
\text { (MICRO- } \\
\text { MHOS) }\end{array}$ & $\begin{array}{c}\text { PH } \\
\text { FIELD } \\
\text { (UNITS) }\end{array}$ & $\begin{array}{c}\text { TEMPER- } \\
\text { ATURE, } \\
\text { WATER } \\
\text { (DEG C) }\end{array}$ & $\begin{array}{l}\text { COLOR } \\
\text { (PLAT- } \\
\text { INUM } \\
\text { COBALT } \\
\text { UNITS) }\end{array}$ & $\begin{array}{l}\text { TUR- } \\
\text { BID- } \\
\text { ITY } \\
\text { (NTU) }\end{array}$ & $\begin{array}{c}\text { OXYGEN, } \\
\text { DIS- } \\
\text { SOLVED } \\
\text { (MG/L) }\end{array}$ & $\begin{array}{l}\text { OXYGEN, } \\
\text { DIS- } \\
\text { SOLVED } \\
\text { (PER- } \\
\text { CENT } \\
\text { SATUR- } \\
\text { ATION) }\end{array}$ & $\begin{array}{c}\text { OXYGEN } \\
\text { DEMAND, } \\
\text { B IOCHEM } \\
\text { UNINH I } \\
5 \text { DAY } \\
\text { (MG/L) }\end{array}$ \\
\hline \multicolumn{11}{|l|}{ OCT } \\
\hline $11 \ldots$ & 1305 & .02 & 703 & 7.4 & 23.5 & 10 & 8.0 & 4.9 & 58 & 2.1 \\
\hline $\operatorname{Nov} \ldots$ & \multicolumn{10}{|c|}{ NoV } \\
\hline$\underset{\text { JAN }}{28} \cdots$ & 1225 & .22 & 810 & 7.2 & 12.5 & 5 & 2.6 & 4.0 & 37 & 1.9 \\
\hline $\begin{array}{l}09 \ldots \\
22 \ldots\end{array}$ & $\begin{array}{l}1315 \\
1700\end{array}$ & $64^{.63}$ & $\begin{array}{l}911 \\
523\end{array}$ & $\begin{array}{l}7.3 \\
7.3\end{array}$ & $\begin{array}{l}10.5 \\
11.0\end{array}$ & $\begin{array}{r}20 \\
200\end{array}$ & $620^{3.6}$ & $\begin{array}{r}8.5 \\
10.0\end{array}$ & $\begin{array}{l}77 \\
92\end{array}$ & $\begin{array}{l}2.5 \\
3.6\end{array}$ \\
\hline $23 \ldots$ & 1330 & 11 & -- & -- & 10.5 & -- & -- & - & -- & - \\
\hline \multicolumn{11}{|l|}{ MAR } \\
\hline $27 \ldots$ & -- & 303 & - & -- & - & -- & - & $\omega$ & -- & -- \\
\hline $27 \ldots$ & 1230 & 78 & 1240 & -- & -- & -- & -- & -- & -- & -- \\
\hline $27 \ldots$ & 1330 & 152 & 1250 & -- & -- & -- & -- & - & -- & $\cdots$ \\
\hline $27 \ldots$ & 1415 & 229 & 1100 & - & -- & -- & -- & -- & -- & -- \\
\hline $27 \ldots$ & 1515 & 294 & 900 & -- & -- & -- & -- & -- & -- & -- \\
\hline $27 \ldots$ & 1650 & 518 & 393 & 7.2 & 15.0 & 120 & 720 & 8.1 & 78 & 5.2 \\
\hline $27 \ldots$ & 1702 & 552 & - & -- & 15.0 & -. & - & -. & -- & $\cdots$ \\
\hline $28 \ldots$ & & 187 & -- & -- & - & -- & -- & -- & - & -- \\
\hline $28 \ldots$ & 1230 & 86 & 212 & 6.7 & 16.5 & 200 & 230 & 9.5 & 98 & 4.3 \\
\hline $\begin{array}{r}28 \ldots \\
\text { MAY }\end{array}$ & 1240 & 85 & & - & 16.5 & $\ldots$ & - & - & -- & -- \\
\hline $13 \ldots$ & -- & 193 & -- & -- & -- & -- & -- & - & -- & -. \\
\hline $13 \ldots$ & 1630 & 127 & 676 & -- & -- & -- & -- & -- & -- & -- \\
\hline $13 \ldots$ & 1700 & 155 & 585 & - & -- & -- & 160 & -- & -- & 8.4 \\
\hline $13 \ldots$ & 1830 & 317 & 350 & -- & -- & -- & -- & -- & -- & -- \\
\hline $13 \ldots$ & 1900 & 451 & 288 & -- & -- & -- & -- & -- & -- & -- \\
\hline $13 \ldots$ & 2100 & 685 & 182 & -- & -- & -- & 540 & -- & -- & 7.2 \\
\hline $13 \ldots$ & 2130 & 709 & 176 & -. & - & -- & -- & $\cdots$ & - & $\cdots$ \\
\hline $14 \ldots$ & -- & 469 & - & -- & -- & -- & -- & -- & -- & -- \\
\hline $14 \ldots$ & 1320 & 140 & -- & - & 21.0 & - & -- & - & $\cdots$ & -- \\
\hline \multirow[t]{6}{*}{$27 \ldots$} & - - & 303 & - & - & -- & -- & -- & - & -- & -- \\
\hline & COLI- & COLI - & STREP - & & & & & & & \\
\hline & FOR" & FORM & TOCOCCI & & & & & & & \\
\hline & TOTAL, & FECAL, & FECAL, & HARD- & NESS, & $\begin{array}{l}\text { CALCIUM } \\
\text { DIS- }\end{array}$ & SIUM, & SODIUM, & $\begin{array}{c}A D- \\
S O P P-\end{array}$ & SIUM, \\
\hline & (cols. & $M-M F$ & $\begin{array}{l}\text { R.F AGAR } \\
\text { (COLS }\end{array}$ & IESS & $\begin{array}{l}\text { FUHCAK- } \\
\text { BONATE }\end{array}$ & SOLVED & DIS- & SOLVED & TURP & SOLVED \\
\hline & PER & (COLS.) & & AS & $(\mathrm{MC} / \mathrm{L}$ & $(\mathrm{MC} / \mathrm{L}$ & (MG / L & (MG/L & RATIO & (MG/L \\
\hline DATE & $100 \mathrm{ML})$ & $100(14 \mathrm{~L})$ & $(00 \mathrm{ML})$ & (ACO3) & (ACO3) & AS (A) & AS MG) & AS NA) & & AS $K)$ \\
\hline \multicolumn{11}{|l|}{$\mathrm{OCT}$} \\
\hline $11 \ldots$ & 1300 & 43 & 460 & 200 & 85 & 57 & 14 & 68 & 2.1 & 6.6 \\
\hline $11 \ldots$ & -- & $\ldots$ & -. & -. & -- & - & -- & -- & - & - \\
\hline \multicolumn{11}{|l|}{ NOV } \\
\hline $28 \ldots$ & 1600 & 92 & 250 & 200 & 71 & 58 & 14 & 73 & 2.2 & 6.1 \\
\hline $09 \ldots$ & 620 & 49 & 46 & -. & -. & -- & -- & -- & -- & -- \\
\hline $22 \ldots$ & - & $\ldots$ & -. & 130 & 85 & 37 & 10 & 43 & 1.6 & 5.2 \\
\hline $23 \ldots$ & -- & $\cdots$ & - & -- & - & - & -- & -- & -- & - \\
\hline \multicolumn{11}{|l|}{ MAR } \\
\hline$: 7 \ldots$ & -- & $\cdots$ & $\cdots$ & $\cdots$ & - & -- & -- & -- & -. & -- \\
\hline $27 \ldots$ & -- & -- & -- & -- & -- & -- & -- & - & -- & - \\
\hline $27 \ldots$ & -- & -- & -- & -- & -- & -. & - & - & -- & -- \\
\hline $27 \ldots$ & -- & - & -- & -- & -- & -- & -- & -- & -- & -- \\
\hline $27 \ldots$ & -- & - & -- & -- & -- & -- & -- & -- & -- & -- \\
\hline $27 \ldots$ & 88000 & 56000 & 310000 & 110 & 65 & 31 & 7.8 & 33 & 1.4 & 5.8 \\
\hline $27 \ldots$ & -- & -- & -- & -- & -- & -- & -- & - & -- & -- \\
\hline $28 \ldots$ & - & -- & -- & -- & -- & -- & $\ldots$ & -- & -- & - \\
\hline $28 \ldots$ & 50000 & 29000 & 91000 & -- & -- & -- & - & -- & -- & -- \\
\hline $28 \ldots$ & -- & $\cdots$ & -- & $\cdots$ & $\cdots$ & - & -- & -- & $=-$ & -- \\
\hline \multicolumn{11}{|l|}{ MAY } \\
\hline $13 \ldots$ & -- & - & - & -- & -- & -- & - & -. & -- & -- \\
\hline $13 \ldots$ & -- & -- & - & -- & -- & -- & -- & -- & -- & -- \\
\hline $13 \ldots$ & - & -- & $\cdots$ & -- & -- & $\cdots$ & -- & -- & -- & -- \\
\hline $13 \ldots$ & -- & -. & -- & - & -- & -. & - & - & -- & - \\
\hline $13 \ldots$ & -- & -- & - & -- & -- & $\cdots$ & -- & - & - & -- \\
\hline $13 \ldots$ & -- & - & -- & -- & -- &.- & $\cdots$ & -- & -- & -- \\
\hline $13 \ldots$ & -- & -. & -- & -- & -- & -- & -- & -- & -- & - \\
\hline $14 \ldots$ & -- & -- & - & $\cdots$ & -- & - & - & -- & -- & -- \\
\hline $14 \ldots$ & -- & -- & -- & -- & -- & $\cdots$ & - & $\cdots$ & -- & -- \\
\hline $27 \ldots$ & -- & -- & -- & -- & -- & -- & - & -- & -- & $\cdots$ \\
\hline
\end{tabular}




\subsection{Water-Quality and Sediment Analysis at Streamflow Sites--Continued}

COLORADO RIVER BASIN

08159165 BIG SANDY CREEK NEAR MCDADE, TX--Continued

WATER QUALITY DATA, WATER YEAR OCTOBER 1979 TO SEPTEMBER 1980

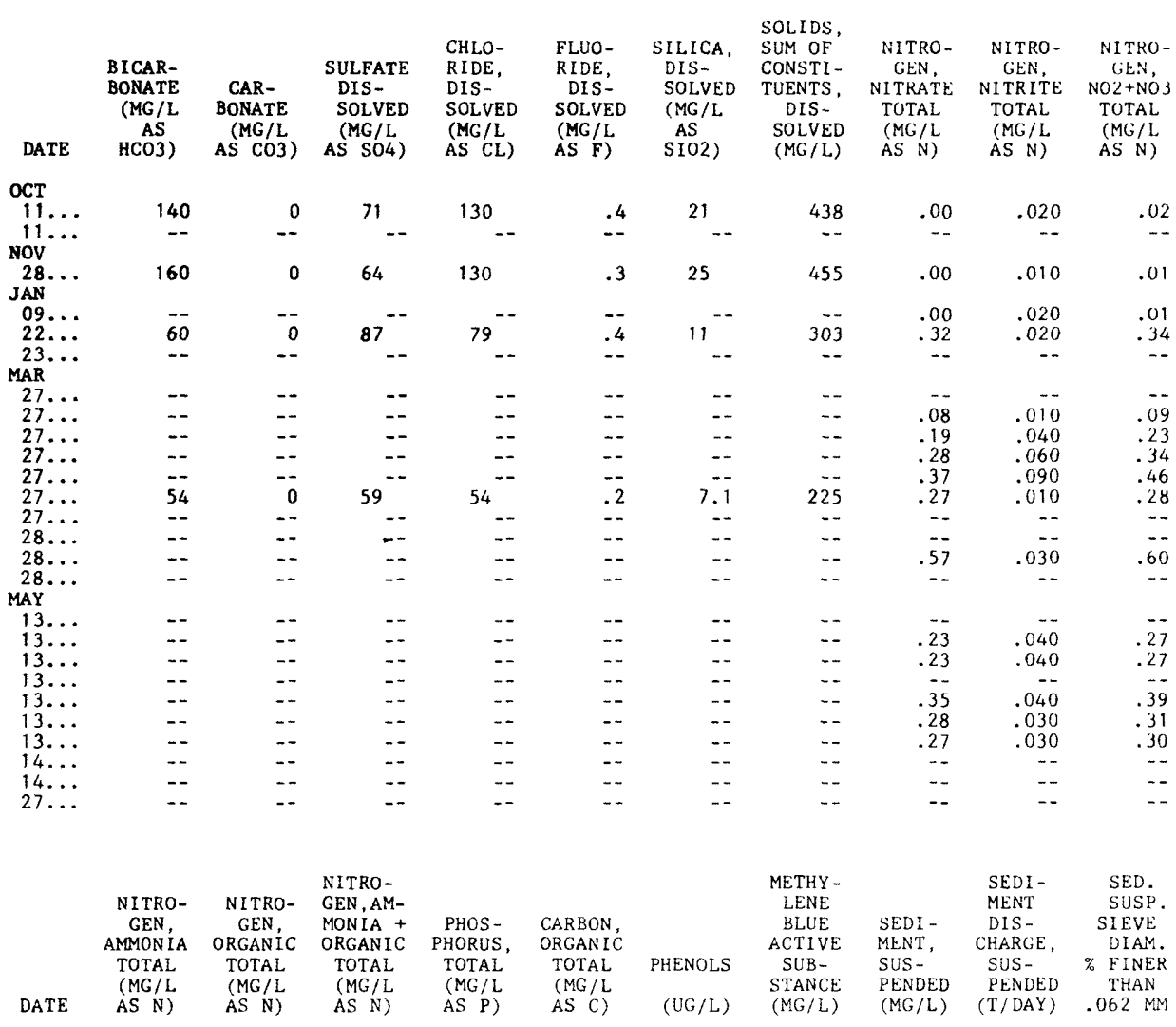

$\begin{array}{rr}\text { OCT } \\ 11 \ldots \\ 11 \ldots & .030 \\ \text { NOV } & - \\ 28 \ldots & .010 \\ \text { JAN } & \\ 09 \ldots & .030 \\ 22 \ldots & .070 \\ 23 \ldots & -- \\ \text { MAR } & \\ 27 \ldots & - \\ 27 \ldots & .160 \\ 27 \ldots & .250 \\ 27 \ldots & .280 \\ 27 \ldots & .200 \\ 27 \ldots & .220 \\ 27 \ldots & -- \\ 28 \ldots & -- \\ 28 \ldots & .120 \\ 28 \ldots & - \\ \text { MAY } \ldots & \\ 13 \ldots & \\ 13 \ldots & .210 \\ 13 \ldots & .210 \\ 13 \ldots & .- \\ 13 \ldots & .200 \\ 13 \ldots & .160 \\ 13 \ldots & .150 \\ 14 \ldots & -- \\ 14 \ldots & -- \\ 27 \ldots & -\end{array}$

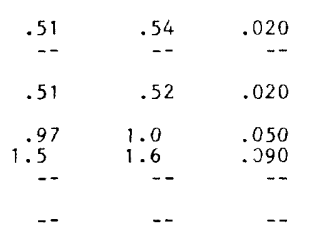

$\begin{array}{lll}1.5 & 1.7^{--} & .160 \\ 1.7 & 1.9 & .190\end{array}$

$\begin{array}{lll}1.7 & 1.9 & .190 \\ 1.4 & 1.7 & .170 \\ 2.2 & 2.4 & .290\end{array}$

$\begin{array}{lll}2.2 & 2.4 & .290 \\ 3.5 & 3.7 & .330\end{array}$

$1 . \overline{6} \quad 1 . \overline{7} \quad .220$

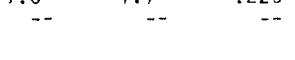

$\begin{array}{ccc}9.9 & 1 & .1 \\ - & -- & \\ 13 & 1 & .00 \\ 6.8 & 0 & .1 \\ 15 & 0 & .00 \\ \ldots & -- & .\end{array}$

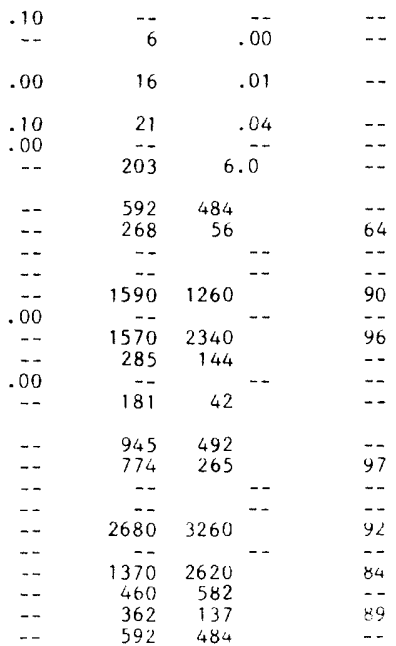

\begin{tabular}{|c|c|c|c|c|c|c|c|}
\hline DATE & TIME & $\begin{array}{c}\text { ARSENIC } \\
\text { DIS - } \\
\text { SULVED } \\
\text { (UG/L } \\
\text { AS AS) }\end{array}$ & $\begin{array}{l}\text { BARIUM, } \\
\text { DIS- } \\
\text { SOLVED } \\
\text { (UG/L } \\
\text { AS BA) }\end{array}$ & $\begin{array}{l}\text { CAWILE } \\
\text { DIS- } \\
\text { BUIVED } \\
\text { GU'L } \\
\text { AS CD) }\end{array}$ & $\begin{array}{l}\text { CRO- } \\
\text { YLLA, } \\
\text { DIS- } \\
\text { SOLVED } \\
\text { (UG'L } \\
\text { AS CR) }\end{array}$ & $\begin{array}{l}\text { COPPER, } \\
\text { DIS- } \\
\text { SOLVED } \\
\text { (UG /L } \\
\text { AS CU) }\end{array}$ & $\begin{array}{l}\text { IRON, } \\
\text { DIS- } \\
\text { SOLVED } \\
\text { (UG/L } \\
\text { AS FE) }\end{array}$ \\
\hline $\begin{array}{l}\text { OCT } \\
11 \ldots\end{array}$ & 1305 & $n$ & 200 & $\Leftrightarrow 1$ & 0 & 0 & 10 \\
\hline NOV & & & & & & & \\
\hline $28 \ldots$ & 1225 & 1 & 300 & $<1$ & 0 & 0 & $<10$ \\
\hline $\begin{array}{l}22 \\
\text { MAR }\end{array}$ & 1700 & 1 & 200 & 1 & is & 2 & $\angle O$ \\
\hline $27 \ldots$ & 1650 & 1 & 200 & $<1$ & 0 & 2 & 70 \\
\hline
\end{tabular}


10.3 Water-Quality and Sediment Analysis at Streamflow Sites--Continued

COLORADO RIVER BASIN

08159165 BIG SANDY CREEK NEAR MCDADE, TX--Continued

WATER QUALITY DATA, WATER YEAR OCTOBER 1979 TO SEPTEMBER 1980

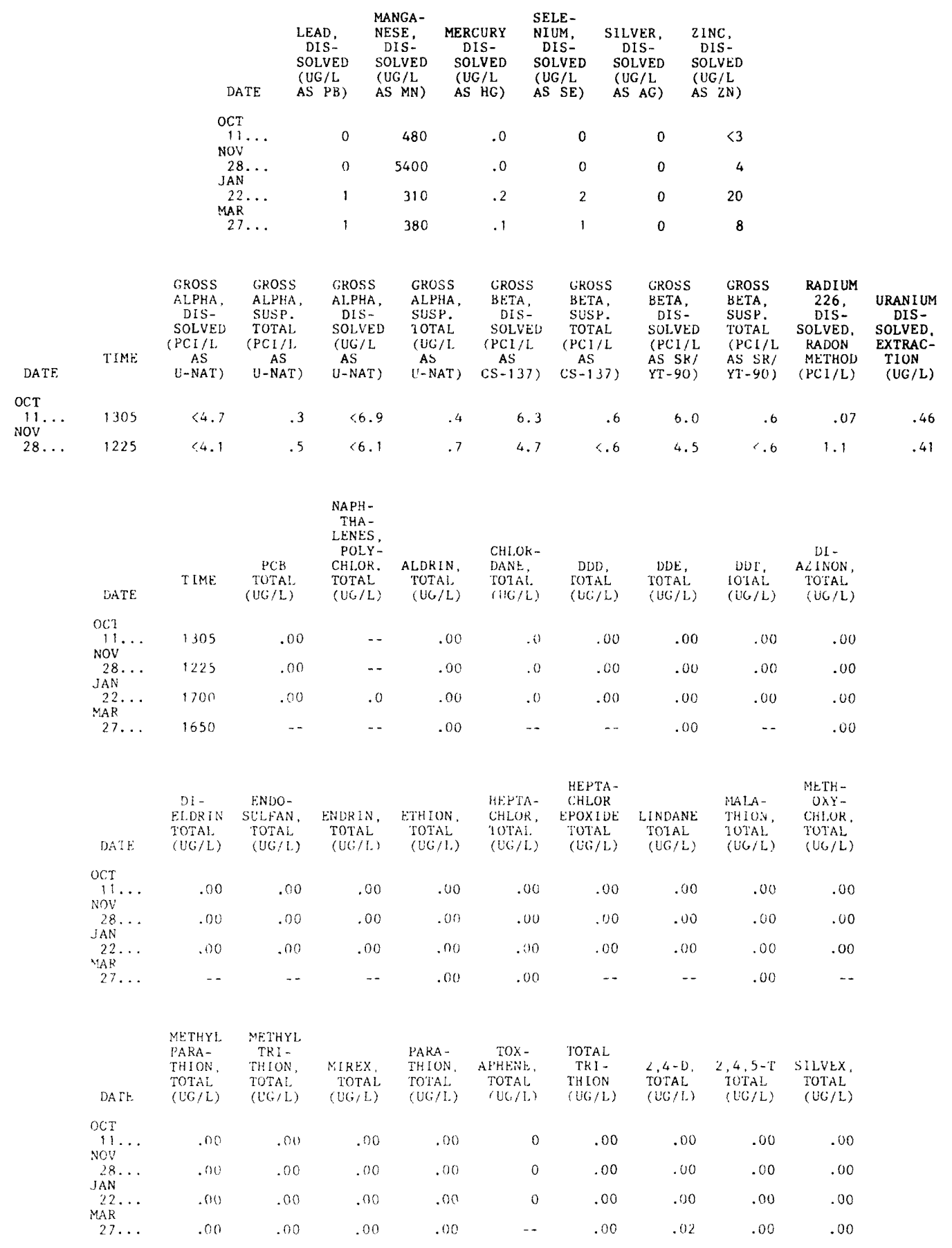


COLORADU KIVEK DADIA

08159165 BIG SANDY CREFK NEAR MCDADL, TX--Continued

WATFR QUAIITY DATA, WATER YIAR OCTOBER 1979 TO SEPTEMBER 1980

\begin{tabular}{|c|c|c|c|c|c|c|c|}
\hline DATE & TIME & $\begin{array}{l}\text { STREAM- } \\
\text { FLOW, } \\
\text { INSTAN- } \\
\text { TANEOUS } \\
\text { (CFS) }\end{array}$ & $\begin{array}{c}\text { TEMPER - } \\
\text { ATURE, } \\
\text { WATER } \\
\text { (DEG C) }\end{array}$ & $\begin{array}{l}\text { SEDI - } \\
\text { MENT, } \\
\text { SUS- } \\
\text { PENDED } \\
\text { (MG/L) }\end{array}$ & $\begin{array}{l}\text { SEDI- } \\
\text { MENT } \\
\text { DIS- } \\
\text { CHARCE, } \\
\text { SUS- } \\
\text { PENDED } \\
\text { (T/DAY) }\end{array}$ & $\begin{array}{l}\text { SED. } \\
\text { SUSP. } \\
\text { FALL } \\
\text { DIAM. } \\
\% \text { FINER } \\
\text { THAN } \\
.002 \mathrm{MM}\end{array}$ & $\begin{array}{l}\text { SED. } \\
\text { SUSP. } \\
\text { FALL } \\
\text { DIAM. } \\
\% \text { FINER } \\
\text { THAI } \\
.004 \text { MM }\end{array}$ \\
\hline${ }^{\text {OCT }} 11 \ldots$ & 1315 & .03 & 23.5 & 6 & .00 & -- & $\cdots$ \\
\hline $\begin{array}{l}\text { NOV } \\
28 \ldots \\
\text { JAN }\end{array}$ & 1225 & .22 & 12.5 & 16 & .01 & -- & -- \\
\hline $\begin{array}{r}09 \ldots \\
23 \ldots \\
M A R\end{array}$ & $\begin{array}{l}1315 \\
1330\end{array}$ & $11^{.63}$ & $\begin{array}{l}10.5 \\
10.5\end{array}$ & $\begin{array}{r}21 \\
203\end{array}$ & 6.04 & -- & -- \\
\hline $\begin{array}{l}27 \ldots \\
27 \ldots \\
27 \ldots \\
27 \ldots \\
28 \ldots \\
28 \ldots\end{array}$ & $\begin{array}{l}1230^{--} \\
1515 \\
1702 \\
1240^{--}\end{array}$ & $\begin{array}{r}303 \\
78 \\
294 \\
552 \\
187 \\
85\end{array}$ & $\begin{array}{r}-- \\
-- \\
15.0 \\
16.5\end{array}$ & $\begin{array}{r}592 \\
268 \\
1590 \\
1570 \\
285 \\
181\end{array}$ & $\begin{array}{r}484 \\
56 \\
1260 \\
2340 \\
144 \\
42\end{array}$ & $\begin{array}{l}-- \\
-- \\
-\overline{7} \\
-- \\
--\end{array}$ & $\begin{array}{l}=- \\
-- \\
84 \\
-- \\
--\end{array}$ \\
\hline $\begin{array}{r}M A Y \\
13 \ldots \\
13 \ldots \\
13 \ldots \\
13 \ldots \\
14 \ldots \\
14 \ldots \\
27 \ldots\end{array}$ & $\begin{array}{c}1630 \\
1900 \\
2130 \\
1320^{--} \\
-\end{array}$ & $\begin{array}{l}193 \\
127 \\
451 \\
709 \\
469 \\
140 \\
303\end{array}$ & $\begin{array}{r}-- \\
-- \\
-- \\
-- \\
21.0 \\
--\end{array}$ & $\begin{array}{r}945 \\
774 \\
2680 \\
1370 \\
460 \\
362 \\
592\end{array}$ & $\begin{array}{r}492 \\
265 \\
3260 \\
2620 \\
582 \\
137 \\
484\end{array}$ & $\begin{array}{l}-- \\
55 \\
80 \\
74 \\
-- \\
-- \\
--\end{array}$ & $\begin{array}{l}-- \\
62 \\
81 \\
77 \\
-- \\
-- \\
--\end{array}$ \\
\hline
\end{tabular}

\begin{tabular}{|c|c|c|c|c|c|c|c|}
\hline & $\begin{array}{ll} & \text { SED. } \\
& \text { SUSP. } \\
& \text { FALI } \\
& \text { DIAM. } \\
\% & \text { FINER } \\
& \text { THANI }\end{array}$ & $\begin{array}{l}\text { SED. } \\
\text { SUSP. } \\
\text { FALI } \\
\text { DIAM. } \\
\% \text { FINER } \\
\text { THAN }\end{array}$ & $\begin{array}{ll}\text { SED. } \\
\text { SUSP. } \\
\text { FALL } \\
\text { DIAM. } \\
\% \text { FINER } \\
\text { THAII }\end{array}$ & $\begin{array}{l}\text { SED. } \\
\text { SUSP. } \\
\text { SIEVE } \\
\text { DIAM. } \\
\% \text { FINER } \\
\text { THAN }\end{array}$ & $\begin{array}{l}\text { SED. } \\
\text { SUSP. } \\
\text { SIEVE } \\
\text { DIAM. } \\
\% \text { FINER } \\
\text { THAN }\end{array}$ & $\begin{array}{l}\text { SED. } \\
\text { SUSP. } \\
\text { SIEVE } \\
\text { DIAM. } \\
\% \text { FINLR } \\
\text { THAN }\end{array}$ & $\begin{array}{l}\text { SED. } \\
\text { SUSP. } \\
\text { SIEVE } \\
\text { DIAM. } \\
\% \text { FINER } \\
\text { THAN }\end{array}$ \\
\hline DATE & $.008 \mathrm{MM}$ & $.016 \mathrm{MM}$ & $.031 \mathrm{MM}$ & $.062 \mathrm{MM}$ & $.125 \mathrm{MM}$ & $.250 \mathrm{MM}$ & $.500 \mathrm{MM}$ \\
\hline OCT & & & & & & & \\
\hline & -- & - & - & -- & -- & -- & -- \\
\hline JAII $\cdots$ & - & -- & - & -- & -- & -- & -- \\
\hline $09 \ldots$ & -- & -- & -- & -- & -- & - & -- \\
\hline$\underset{M A R}{23} \cdots$ & -- & - & -- & $\cdots$ & -- & - & -- \\
\hline $27 \ldots$ & -- & -- & -- & -- & -- & $\cdots$ & -- \\
\hline $27 \ldots$ & - & -- & $\cdots$ & 64 & 72 & 92 & 99 \\
\hline $27 \ldots$ & -- & - & -. & 90 & 96 & $\ldots$ & 100 \\
\hline $27 \ldots$ & 90 & 93 & 95 & 96 & 97 & 99 & 100 \\
\hline $28 \ldots$ & - & - & -- & -- & -- & -- & -- \\
\hline $28 \cdots$ & -- & -- & -- & -- & $\cdots$ & - & - \\
\hline $13 \ldots$ & -. & -- & -- & -- & -- & - & - \\
\hline $13 \ldots$ & 67 & 70 & 90 & 97 & 98 & 99 & 99 \\
\hline $13 \ldots$ & 88 & 88 & 89 & 92 & 93 & 98 & 99 \\
\hline $13 \ldots$ & 81 & 82 & 84 & 84 & 85 & 97 & 99 \\
\hline $14 \ldots$ & -- & -- & -- & -- & - & - & -- \\
\hline $14 \ldots$ & -- & -- & -- & 89 & 95 & 99 & 99 \\
\hline $27 \ldots$ & -- & -- & - & -- & -- & -- & -- \\
\hline
\end{tabular}


08159170 BIG SANDY CREEK NEAR ELGIN, TX

PERIOD OF RECORD.--Chemical, biochemical, radiochemical, and pesticide analyses: May to September 1979.

WATER QUALITY DATA, WATER YEAR OCTOBER 1978 TO SEPTEMBER 1979

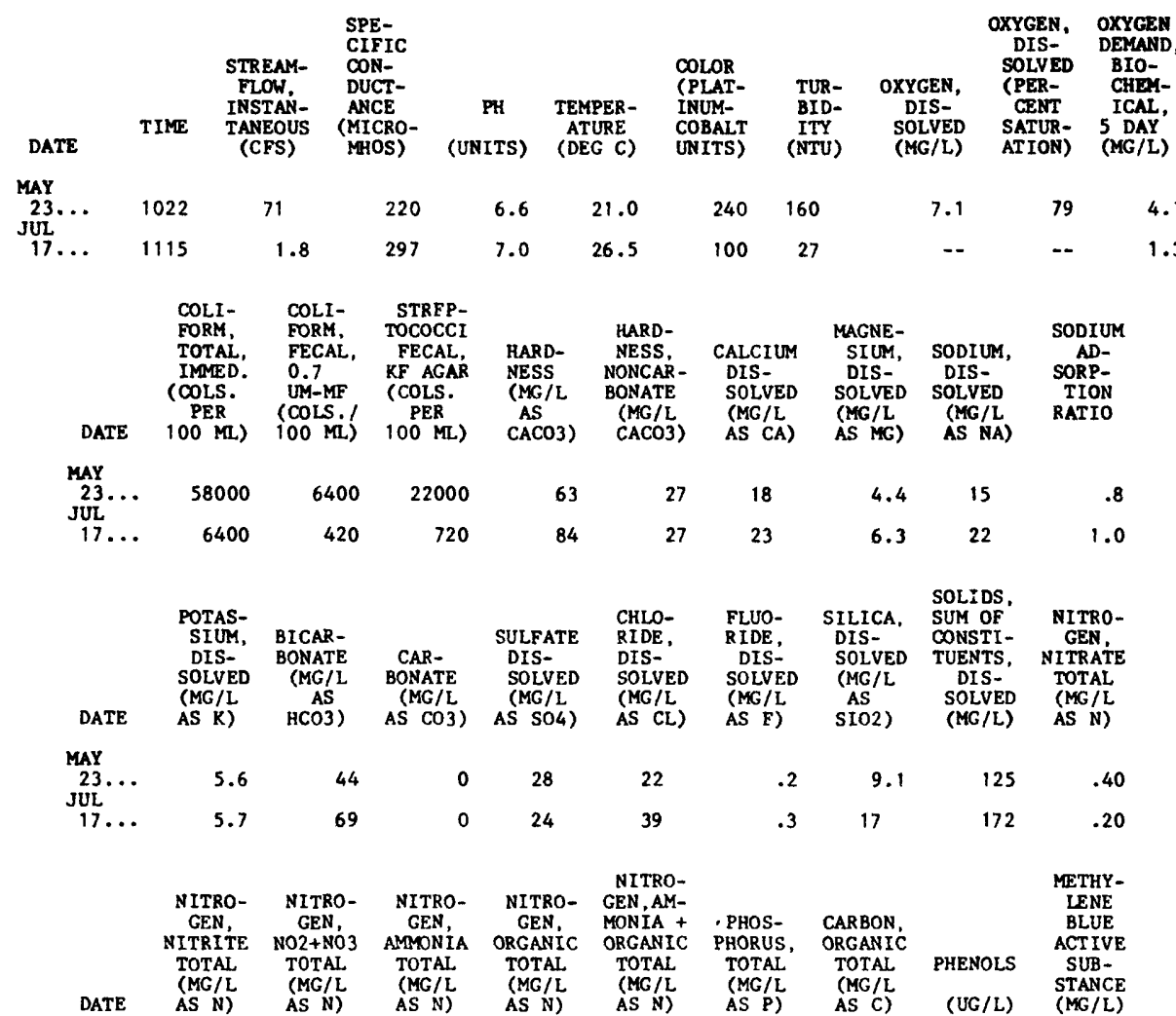

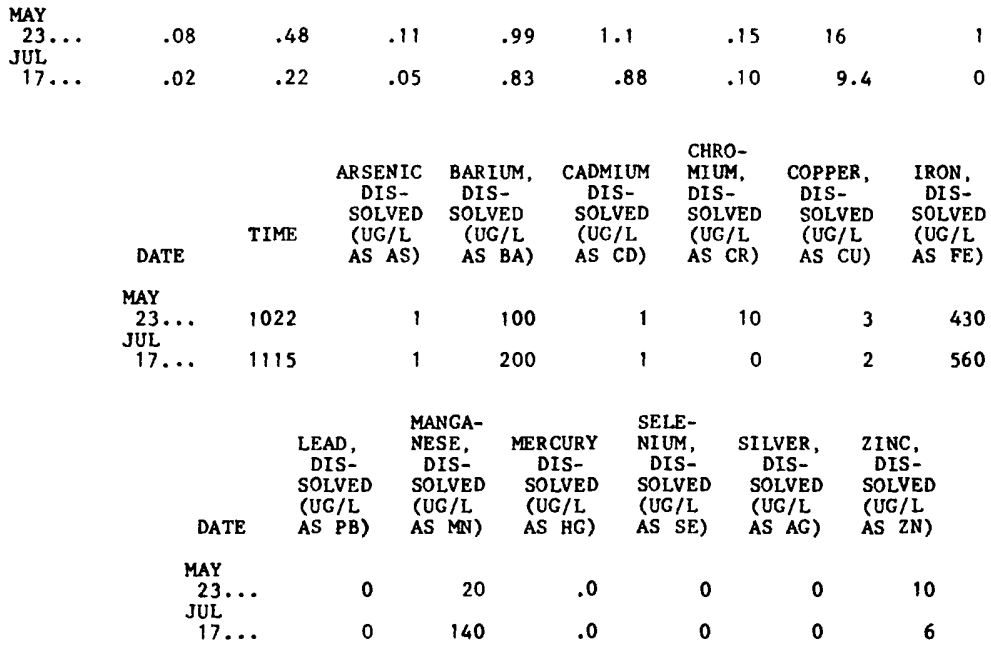


10.0 SUPPLEMENTAL DATA--Continued

10.3 Water-Quality and Sediment Analysis at Streamflow Sites--Continued

COLORADO RIVER BASIN

08159170 BIG SANDY CREER MEAR ELGIN, IX--Cont1nued

WATER QVALIT OATA, WATER YEAR OCTOBER 1978 TO SEPTEMBER 1979

\begin{tabular}{|c|c|c|c|c|c|c|c|c|c|c|c|}
\hline DATE & TIME & $\begin{array}{c}\text { GROSS } \\
\text { ALPHA, } \\
\text { DIS- } \\
\text { SOLVED } \\
\text { (PCI/L } \\
\text { AS } \\
\text { U-NAT) }\end{array}$ & $\begin{array}{c}\text { GQOSS } \\
\text { ALPHA, } \\
\text { SUSP. } \\
\text { TOTAL } \\
\text { (PCI/L } \\
\text { AS } \\
\text { U-NAT) }\end{array}$ & $\begin{array}{l}\text { GROSS } \\
\text { AIPHA, } \\
\text { DIS- } \\
\text { SOLVED } \\
\text { (UG/L } \\
\text { AS } \\
\text { U-NAT) }\end{array}$ & $\begin{array}{l}\text { GROSS } \\
\text { ALPHA, } \\
\text { SUSP. } \\
\text { TOTAL } \\
\text { (UG/L } \\
\text { AS } \\
\text { U-NAT) }\end{array}$ & $\begin{array}{c}\text { GROSS } \\
\text { BETA, } \\
\text { DIS- } \\
\text { SOLVED } \\
\text { (PCI/L } \\
\text { AS } \\
\text { CS }-137)\end{array}$ & $\begin{array}{c}\text { GROSS } \\
\text { BETA, } \\
\text { SUSP. } \\
\text { TOTAL } \\
\text { (PCI/L } \\
\text { AS } \\
\text { CS-137) }\end{array}$ & $\begin{array}{l}\text { GROSS } \\
\text { BETA, } \\
\text { DIS- } \\
\text { SOLVED } \\
\text { (PCI/L } \\
\text { AS SR / } \\
\text { YT-90) }\end{array}$ & $\begin{array}{l}\text { GROSS } \\
\text { SEIA, } \\
\text { SUSP. } \\
\text { TOTAL } \\
\text { (PCI/L } \\
\text { AS SR/ } \\
\text { YT-90) }\end{array}$ & $\begin{array}{l}\text { RADIUM } \\
226, \\
\text { DIS- } \\
\text { SOLVED, } \\
\text { RADON } \\
\text { METHOD } \\
\text { (PCI/L) }\end{array}$ & $\begin{array}{l}\text { JRARIC } \\
\text { DIS- } \\
\text { SOLVED } \\
\text { BXTRAC } \\
\text { TION } \\
\text { (UG/L) }\end{array}$ \\
\hline \\
\hline $23 \ldots$ & 022 & $<1.3$ & 7.5 & $<1.9$ & 11 & 6.7 & $\langle 7.1$ & 5.2 & 8.3 & .08 & 1 \\
\hline 17 & 1115 & $<1.6$ & 1.6 & $<2.4$ & 2.3 & 6.1 & 1.8 & 5.7 & 1.8 & .08 & $<.0$ \\
\hline
\end{tabular}
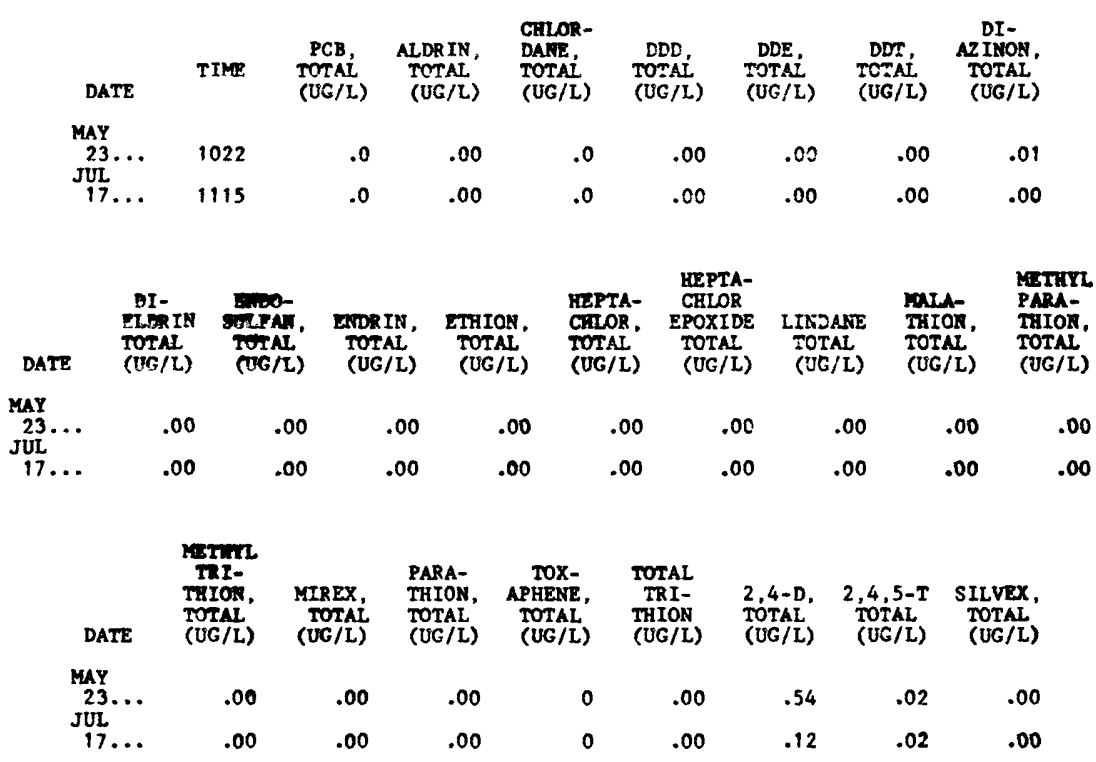
COLOR.ADO RIVER BASIN

08159170 BIG SANDY CREEK NEAR ELGIN, TX--Continued

WATER-QUALITY RECORDS

PERIOD OF RECORD.--Chemical, biochemical, and pesticide analyses: May 1979 to current year. Radiochemical analyses: May to Septemher 1979.

WATER QUALITY DATA, WATER YEAR OCTOBER 1979 TO SEPTEMBER 1980

\begin{tabular}{|c|c|c|c|c|c|c|c|c|c|c|c|}
\hline DATE & TIME & $\begin{array}{l}\text { STREAM- } \\
\text { FLOW, } \\
\text { INSTAN- } \\
\text { TAHEOUS } \\
\text { (CFS) }\end{array}$ & $\begin{array}{l}\text { SPE- } \\
\text { CIFIC } \\
\text { CON- } \\
\text { DUCT- } \\
\text { ANCE } \\
\text { (MICRO- } \\
\text { MHOS) }\end{array}$ & $\begin{array}{c}\text { PH } \\
\text { FIELD } \\
\text { (UNITS) }\end{array}$ & $\begin{array}{c}\text { TEMPER- } \\
\text { ATURE. } \\
\text { WATER } \\
\text { (DEG C) }\end{array}$ & $\begin{array}{l}\text { COLOR } \\
\text { (PLAT- } \\
\text { INUM } \\
\text { COBALT } \\
\text { UNITS) }\end{array}$ & $\begin{array}{l}\text { TUR } \\
\text { BID } \\
\text { ITY } \\
\text { (NTL }\end{array}$ & & $\begin{array}{c}\text { OXYGEN, } \\
\text { DIS- } \\
\text { SOLVED } \\
\text { (MG /L) }\end{array}$ & $\begin{array}{c}\text { OXYGEN, } \\
\text { DIS- } \\
\text { SOLVED } \\
\text { (PER- } \\
\text { CENT } \\
\text { SATUR- } \\
\text { ATION) }\end{array}$ & $\begin{array}{l}\text { OXYGEN } \\
\text { DEMAND, } \\
\text { BIOCHEM } \\
\text { UNINHIB } \\
5 \text { DAY } \\
(M G / L)\end{array}$ \\
\hline $\begin{array}{l}\text { OCT } \\
11 \ldots .\end{array}$ & 1110 & .30 & 416 & 6.9 & 16.0 & 20 & 7. & & 2.9 & 30 & 2.4 \\
\hline $\begin{array}{l}\text { NOV } \\
28 \ldots \\
\text { JAI }\end{array}$ & 1100 & 1.3 & 342 & 6.9 & 11.0 & 70 & 7. & & 4.5 & 40 & 3.7 \\
\hline $\begin{array}{l}09 \ldots \\
09 \ldots \\
22 \ldots \\
23 \ldots \\
\text { MAR }\end{array}$ & $\begin{array}{l}1100 \\
1110 \\
1530 \\
1210\end{array}$ & $\begin{array}{r}.66 \\
108^{.69} \\
29\end{array}$ & $\begin{array}{r}677 \\
431 \\
--\end{array}$ & $\begin{array}{l}7.2 \\
-. \\
7.3 \\
--\end{array}$ & $\begin{array}{r}9.5 \\
8.5 \\
11.5 \\
9.5\end{array}$ & $\begin{array}{r}20 \\
120 \\
--\end{array}$ & $\begin{array}{r}19 \\
220\end{array}$ & 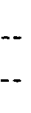 & $\begin{array}{r}8.4 \\
-.3 \\
9.3\end{array}$ & $\begin{array}{l}74 \\
-1 \\
85 \\
--\end{array}$ & $\begin{array}{r}2.5 \\
3.8 \\
-.-\end{array}$ \\
\hline $\begin{array}{l}27 \ldots \\
27 \ldots\end{array}$ & $1456^{--}$ & $\begin{array}{l}216 \\
163\end{array}$ & $1 \overline{87}$ & $6 . \overline{9}$ & $15 . \overline{0}$ & 200 & 370 & -- & $10 . \overline{9}$ & 105 & $5 . \overline{2}$ \\
\hline $27 \ldots$ & 1510 & $\begin{array}{l}178 \\
488\end{array}$ & -- & -- & 15.0 & $=$ & & - & -- & $=$ & 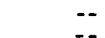 \\
\hline $\begin{array}{l}28 \ldots \\
28 \ldots\end{array}$ & $\begin{array}{l}1105 \\
1130\end{array}$ & $\begin{array}{l}271 \\
265\end{array}$ & 139 & 7.0 & $\begin{array}{l}15.5 \\
15.5\end{array}$ & 200 & 300 & -- & 9.5 & 95 & $\begin{array}{r}4.6 \\
-.-\end{array}$ \\
\hline MAY & & & & & & & & & & & \\
\hline $12 \ldots$ & & 8.3 & $\cdots$ & $\cdots$ & - & -- & & - & - & - & -- \\
\hline $12 \cdots$ & 2200 & 27 & 205 & $-\overline{3}$ & -- & - & & - & -- & - & 6.6 \\
\hline $13 \ldots$ & 2300 & $\begin{array}{r}58 \\
205\end{array}$ & $\begin{array}{r}231 \\
--\end{array}$ & 8.5 & $\overline{-}$ & 200 & 530 & -- & $\because$ & $=$ & -- \\
\hline $13 \ldots$ & 0015 & 43 & 218 & $=-$ & - & -- & & - & -- & -1 & -- \\
\hline 13. & 0200 & 51 & 143 & -- & -- & -- & & -- & -- & -. & 5.1 \\
\hline & 00 & 5 & 13 & 7.4 & -- & 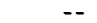 & & - & - & - & \\
\hline 1 & & 1000 & $\cdots$ & -- & -- & -- & & - & - & -- & -- \\
\hline & 1400 & 1000 & - & -- & 21.5 & -- & & -- & -- & - & -- \\
\hline
\end{tabular}

\begin{tabular}{|c|c|c|c|c|c|c|c|c|c|c|}
\hline DATE & $\begin{array}{l}\text { COLI- } \\
\text { FORM. } \\
\text { TOTAL, } \\
\text { IMMED. } \\
\text { (COLS. } \\
\text { PER } \\
100 \mathrm{ML} \text { ) }\end{array}$ & $\begin{array}{l}\text { COLI- } \\
\text { FORM, } \\
\text { FECAL, } \\
0.7 \\
\text { UM-MF } \\
\text { (COLS./ } \\
\text { 100 ML) }\end{array}$ & $\begin{array}{c}\text { STREP- } \\
\text { TOCOCCI } \\
\text { FECAL, } \\
\text { KF ACAR } \\
\text { (COLS. } \\
\text { PER } \\
100 \mathrm{ML} \text { ) }\end{array}$ & $\begin{array}{l}\text { HARD- } \\
\text { NESS } \\
\text { (MG/L } \\
\text { AS } \\
\text { CACO3) }\end{array}$ & $\begin{array}{l}\text { HARD- } \\
\text { NESS, } \\
\text { NONCAR- } \\
\text { BONATE } \\
\text { (MG/L } \\
\text { CACO3) }\end{array}$ & $\begin{array}{l}\text { CALCITM } \\
\text { DIS- } \\
\text { SOLVED } \\
\text { (MG /L } \\
\text { AS CA) }\end{array}$ & $\begin{array}{l}\text { MACNE- } \\
\text { SILM, } \\
\text { DIS- } \\
\text { SOLVED } \\
\text { (MG /L } \\
\text { AS MG) }\end{array}$ & $\begin{array}{c}\text { SODIUM, } \\
\text { DIS- } \\
\text { SOLVED } \\
\text { (MG/L } \\
\text { AS NA) }\end{array}$ & $\begin{array}{l}\text { SODIUM } \\
\text { AD- } \\
\text { SORP- } \\
\text { TION } \\
\text { RATYO }\end{array}$ & $\begin{array}{l}\text { POTAS- } \\
\text { SIUM, } \\
\text { DIS- } \\
\text { SOLVED } \\
\text { (MG/L } \\
\text { AS K) }\end{array}$ \\
\hline $\begin{array}{c}\text { OCT } \\
11 \\
\text { NOV }\end{array}$ & 2600 & 120 & 210 & 110 & 32 & 33 & 7.7 & 29 & 1.2 & 6.5 \\
\hline$\underset{\text { JAN }}{28} \cdots$ & 870 & 96 & 220 & 88 & 33 & 24 & 6.9 & 30 & 1.4 & 7.7 \\
\hline $\begin{array}{l}09 \ldots \\
09 \ldots\end{array}$ & $\begin{array}{r}1800 \\
-\end{array}$ & $\begin{array}{r}270 \\
--\end{array}$ & 390 & $=$ & 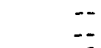 & $=$ & $=$ & -- & $=$ & $\because$ \\
\hline $22 \ldots$ & -- & $m$ & -- & 110 & 75 & 30 & 8.4 & 32 & 1.3 & 6.1 \\
\hline$\underset{\text { MAR }}{23} \cdots$ & -- & -- & -- & -- & $\sim$ & -- & -- & -- & -- & -- \\
\hline $\begin{array}{l}27 \ldots \\
27 \ldots\end{array}$ & 27000 & 11000 & 62000 & $\overline{55}$ & 31 & $15^{--}$ & 4.3 & $17^{--}$ & 1.0 & $4 . \overline{2}$ \\
\hline $27 \ldots$ & -- & -- & $\cdots$ & -- & - & -- & -- & -- & -- & -- \\
\hline $\begin{array}{l}28 \ldots \\
28 \ldots\end{array}$ & $2800 \overline{0}$ & $2600 \overline{0}$ & 100000 & -- & $\overline{-}$ & $=$ & $\because$ & - & $\overline{-}$ & -- \\
\hline $\operatorname{MAY}_{28}^{28}$ & -- &.- & - & -- & $\cdots$ & - & -. & $=$ & - & -- \\
\hline $12 \ldots$ & $-\infty$ & - & -- & -. & - & - & -. & -- & -. & -- \\
\hline $12 \cdots$ & $=$ & -- & -- & $\overline{67}$ & $\overline{18}$ & $19^{--}$ & $-\overline{8}$ & - & $\overline{0}$ & 52 \\
\hline $13 \ldots$ & -- & - & -- & $\ldots 1$ & 18 & 19 & $\begin{array}{l}4.8 \\
-.-\end{array}$ & 18 & 1.0 & $\begin{array}{l}3.2 \\
-.-\end{array}$ \\
\hline $13 \ldots$ & $=-$ & -- & -- & -- & -- & - & -. & -- & -- & -- \\
\hline & -- & - & -- & - & $\ldots$ & -- & - & $=-$ & -- & -- \\
\hline $13 \ldots$ & -- & -- & $\sim$ & 49 & 20 & 14 & 3.5 & 12 & .7 & 5.3 \\
\hline 14. & -- & -- & -- & -- & -- & -- & -- & -- & -- & -- \\
\hline 14. & -- & -- & -- & -- & -- & -- & -- & -- & -- & -- \\
\hline
\end{tabular}


COLORADO RIVER BASIN

08159170 BIG SANDY CREEK NEAR ELGIN, TX--Continued

WATER QUALITY DATA, WATER YEAR OCTOBER 1979 TO SEPTEMBER 1980

\begin{tabular}{|c|c|c|c|c|c|c|c|c|c|c|}
\hline DATE & $\begin{array}{c}\text { BICAR- } \\
\text { BONATE } \\
\text { (MG/L } \\
\text { AS } \\
\text { HCO3) }\end{array}$ & $\begin{array}{c}\text { CAR- } \\
\text { BONATE } \\
(\mathrm{MG} / \mathrm{L} \\
\text { AS CO3) }\end{array}$ & $\begin{array}{l}\text { SULFATE } \\
\text { DIS- } \\
\text { SOLVED } \\
\text { (MG/L } \\
\text { AS SO4) }\end{array}$ & $\begin{array}{l}\text { CHLO- } \\
\text { RIDE, } \\
\text { DIS- } \\
\text { SOLVED } \\
\text { (MG/L } \\
\text { AS CL) }\end{array}$ & $\begin{array}{l}\text { FLUO- } \\
\text { RIDE, } \\
\text { DIS- } \\
\text { SOLVED } \\
\text { (MG/L } \\
\text { AS F) }\end{array}$ & $\begin{array}{l}\text { SILICA, } \\
\text { DIS- } \\
\text { SOLVED } \\
\text { (MG/1. } \\
\text { AS } \\
\text { SIO2) }\end{array}$ & $\begin{array}{l}\text { SOLIDS, } \\
\text { SUM OF } \\
\text { CONSTI- } \\
\text { TUENTS, } \\
\text { DIS- } \\
\text { SOLVED } \\
\text { (MG/L) }\end{array}$ & $\begin{array}{c}\text { NITRO- } \\
\text { GEN, } \\
\text { NITRATE } \\
\text { TOTAL } \\
\text { (MG/L } \\
\text { AS N) }\end{array}$ & $\begin{array}{l}\text { NITRO- } \\
\text { GEN, } \\
\text { NITRITE } \\
\text { TOTAL } \\
\text { (MG/L } \\
\text { AS N) }\end{array}$ & $\begin{array}{c}\text { NITRO- } \\
\text { GEN, } \\
\text { NO2+NO3 } \\
\text { TOTAL } \\
\text { (MG/L } \\
\text { AS N) }\end{array}$ \\
\hline $\begin{array}{c}\text { OCT } \\
11 \ldots \\
\text { Nov }\end{array}$ & 100 & 0 & 25 & 59 & .3 & 24 & 235 & .00 & .020 & .01 \\
\hline$\underset{\text { JAN }}{28} \ldots$ & 68 & 0 & 20 & 56 & .2 & 30 & 210 & .01 & .010 & .02 \\
\hline $\begin{array}{l}09 . \ldots \\
09 . . .\end{array}$ & -- & $=$ & - & $=$ & $=$ & $=$ & $=$ & .00 & .020 & .02 \\
\hline $22 \ldots$ & 42 & 0 & 76 & 51 & .2 & 11 & 236 & .15 & .010 & .16 \\
\hline$\underset{\text { MAR }}{23} \cdots$ & - & -- & $\cdots$ & -- & - & $\cdots$ & -- & $\cdots$ & -- & \\
\hline $\begin{array}{l}27 \ldots \\
27 \ldots\end{array}$ & 30 & $\overline{0}$ & $30^{--}$ & $26^{--}$ & .1 & $9 . \overline{1}$ & $1 \overrightarrow{21}$ & .19 & .010 & .20 \\
\hline $27 \ldots$ & - & -- & -- & -. & - & -- & - & - & -- & .20 \\
\hline 28 . & $\cdots$ & $\cdots$ & -- & $\cdots$ & -- & -- & $\cdots$ & $\because$ & - & \\
\hline $28 \ldots$ & -- & -- & -- & -- & -- & $\cdots$ & -- & .61 & .040 & .65 \\
\hline$\underset{\text { MAY }}{28} \cdots$ & -- & -- & $\cdots$ & -- & -- & -- & -- & -- & -- & \\
\hline $12 \ldots$ & -- & -- & - & -- & -- & -- & -- & $\bar{a}$ & $-\therefore$ & $\overline{7}$ \\
\hline $\begin{array}{l}12 \ldots \\
12 \ldots\end{array}$ & $\overline{60}$ & $\overline{0}$ & $27^{--}$ & $27^{--}$ &.$\overline{-}$ & $12^{--}$ & $\overline{4} \overline{3}$ & .21 & .020 & .23 \\
\hline $13 \ldots$ & - & - & 28 & $21 \ldots$ & $: 2$ & $12 \ldots$ & $\begin{array}{r}143 \\
--\end{array}$ & -- & -- & $\cdots$ \\
\hline $13 \ldots$ & $\cdots$ & -- & $=$ & -- & -- & - & -- & -. & - & 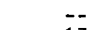 \\
\hline $13 \ldots$ & $=$ & 0 & -- & - & - & $=$ & -- & .15 & .020 & .17 \\
\hline $13 \ldots$ & 36 & 0 & 16 & 26 & .1 & 11 & 106 & -. & -- & . \\
\hline 14. & -- & - & -- & $\cdots$ & -- & -- & -- & - & -- & $\overline{-}$ \\
\hline $14 \ldots$ & -- & -- & - & - & -- & -- & -- & -- & $\cdots$ & $\begin{array}{ll}- \\
-\end{array}$ \\
\hline
\end{tabular}

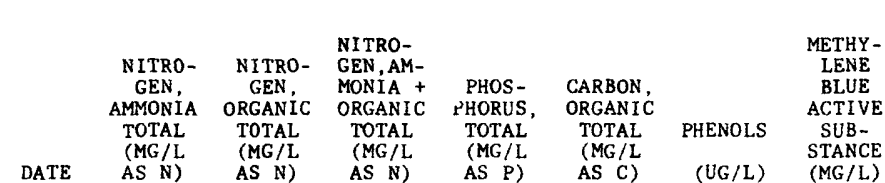

$\begin{array}{llllllll} & (\mathrm{MG} / \mathrm{L} & (\mathrm{MG} / \mathrm{L} & (\mathrm{MG} / \mathrm{L} & \text { (MG } / \mathrm{L} & (\mathrm{MG} / \mathrm{L} & & \text { STANCE } \\ \text { DATE } & \text { AS N) } & \text { AS N) } & \text { AS N) } & \text { AS P) } & \text { AS C) } & (U G / L) & (\mathrm{MG} / \mathrm{L})\end{array}$

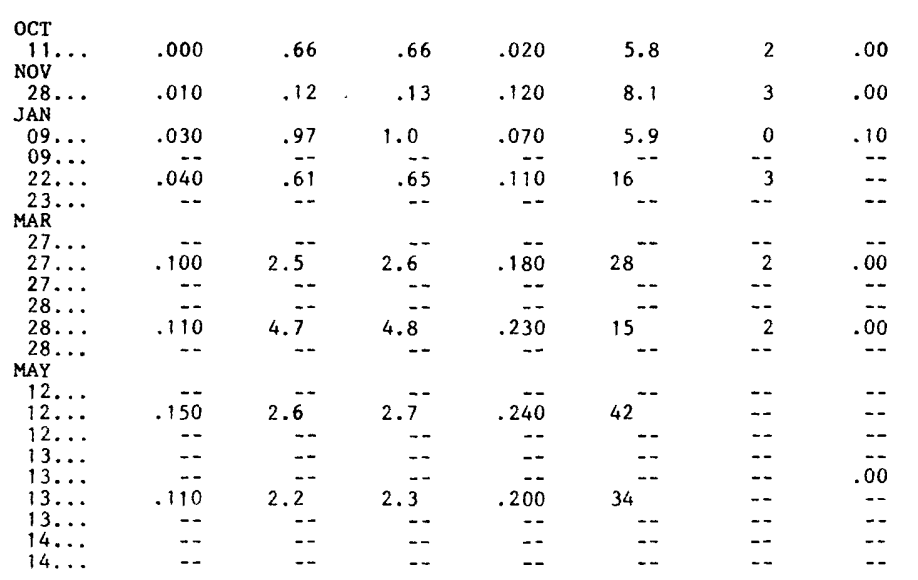

\begin{tabular}{|c|c|c|c|c|c|c|c|}
\hline DATE & TIME & $\begin{array}{c}\text { ARSENIC } \\
\text { DIS- } \\
\text { SOLVED } \\
\text { (UG/L } \\
\text { AS AS) }\end{array}$ & $\begin{array}{l}\text { BARIUM, } \\
\text { DIS- } \\
\text { SOLVED } \\
\text { (UG/L } \\
\text { AS BA) }\end{array}$ & $\begin{array}{l}\text { CADMIUM } \\
\text { DIS- } \\
\text { SOLVED } \\
\text { (UG/L } \\
\text { AS CD) }\end{array}$ & $\begin{array}{l}\text { CHRO- } \\
\text { MIUM, } \\
\text { DIS- } \\
\text { SOLVED } \\
\text { (UG/L } \\
\text { AS CR) }\end{array}$ & $\begin{array}{l}\text { COPPER, } \\
\text { DIS- } \\
\text { SOLVED } \\
\text { (UG/L } \\
\text { AS CU) }\end{array}$ & $\begin{array}{l}\text { IRON, } \\
\text { DIS- } \\
\text { SOLVED } \\
\text { (UG/L } \\
\text { AS FE) }\end{array}$ \\
\hline OCT & & & & & & & \\
\hline${ }_{\text {Nov }}^{11} \ldots$ & 1110 & 0 & 200 & $<1$ & 0 & 0 & 110 \\
\hline $28 \ldots$ & 1100 & 1 & 100 & . & 0 & 0 & 1200 \\
\hline $22 \ldots$ & 1530 & 1 & 100 & 2 & 0 & 1 & 280 \\
\hline $27 \ldots$ & 1456 & 1 & 60 & 1 & 0 & 4 & 560 \\
\hline $\begin{array}{l}12 \ldots \\
13 \ldots\end{array}$ & $\begin{array}{l}2200 \\
0200\end{array}$ & 1 & $\begin{array}{l}90 \\
60\end{array}$ & $\begin{array}{l}<1 \\
<1\end{array}$ & $\begin{array}{l}0 \\
0\end{array}$ & $\begin{array}{r}27 \\
5\end{array}$ & $\begin{array}{l}190 \\
360\end{array}$ \\
\hline
\end{tabular}




\subsection{SUPPLEMENTAL DATA--Continued}

10.3 Water-Quality and Sediment Analysis at Streamflow Sites--Continued

COLORADO RIVER BASIN

08159170 BIG SANDY CREEK NEAR ELGIN, TX--Continued

WATER QUALITY DATA, WATER YEAR OCTOBER 1979 TO SEPTEMBER 1980

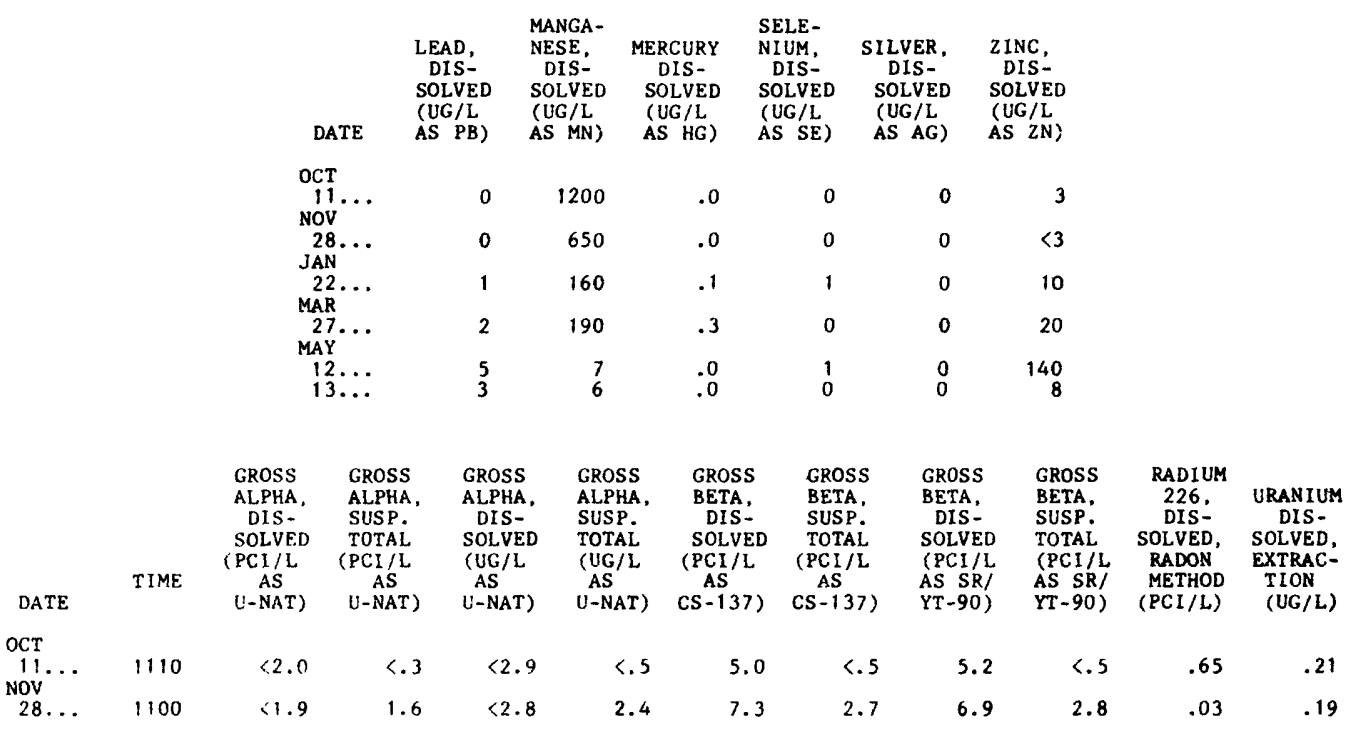

\begin{tabular}{|c|c|c|c|c|c|c|c|c|c|}
\hline DATE & TIME & $\begin{array}{c}\text { PCB } \\
\text { TOTAL } \\
\text { (UG/L) }\end{array}$ & $\begin{array}{l}\text { NAPH- } \\
\text { THA- } \\
\text { LENES, } \\
\text { POLY- } \\
\text { CHLOR. } \\
\text { TOTAL } \\
\text { (UG/L) }\end{array}$ & $\begin{array}{l}\text { ALDR IN, } \\
\text { TOTAL } \\
\text { (UG/L) }\end{array}$ & $\begin{array}{l}\text { CHLOR- } \\
\text { DANE, } \\
\text { TOTAL } \\
\text { (UG/L) }\end{array}$ & $\begin{array}{l}\text { DDD, } \\
\text { TOTAL } \\
\text { (UG/L) }\end{array}$ & $\begin{array}{l}\text { DDE, } \\
\text { TOTAL } \\
\text { (UG/L) }\end{array}$ & $\begin{array}{l}\text { DDT, } \\
\text { TOTAL } \\
\text { (UG/L) }\end{array}$ & $\begin{array}{c}\text { DI - } \\
\text { AZ INON, } \\
\text { TOTAL } \\
\text { (UG/L) }\end{array}$ \\
\hline $\begin{array}{l}\text { OCT } \\
11 . . .\end{array}$ & 1110 & .00 & -- & .00 & .0 & .00 & .00 & .00 & .00 \\
\hline & 1100 & .00 & -. & .00 & .0 & .00 & .00 & .00 & .00 \\
\hline${ }_{\text {MAR }}^{22} \cdots$ & 1530 & .00 & .0 & .00 & .0 & .00 & .00 & .00 & .00 \\
\hline$\underset{M A Y}{27} \cdots$ & 1456 & - & -- & .00 & - & -- & .00 & -- & .00 \\
\hline $13 \ldots$ & 0015 & .00 & .0 & .00 & .0 & .00 & .00 & .00 & .00 \\
\hline DATE & $\begin{array}{l}\text { DI- } \\
\text { ELDRIN } \\
\text { TOTAL } \\
\text { (UG/L) }\end{array}$ & $\begin{array}{l}\text { ENDO- } \\
\text { SULFAN, } \\
\text { TOTAL } \\
\text { (UG/L) }\end{array}$ & $\begin{array}{l}\text { ENDR 1N, } \\
\text { TOTAL } \\
\text { (UG/L) }\end{array}$ & $\begin{array}{c}\text { ETHION, } \\
\text { TOTAL } \\
\text { (UG/L) }\end{array}$ & $\begin{array}{l}\text { HEPTA- } \\
\text { CHLOR, } \\
\text { TOTAL } \\
(U G / L)\end{array}$ & $\begin{array}{l}\text { HEPTA- } \\
\text { CHLOR } \\
\text { EPOXIDE } \\
\text { TOTAL } \\
\text { (UG/L) }\end{array}$ & $\begin{array}{c}\text { LINDANE } \\
\text { TOTAL } \\
(U G / L)\end{array}$ & $\begin{array}{l}\text { MALA- } \\
\text { THION, } \\
\text { TOTAL } \\
\text { (UG /L) }\end{array}$ & $\begin{array}{l}\text { METH- } \\
\text { OXY- } \\
\text { CHLOR, } \\
\text { TOTAL } \\
(U G / L)\end{array}$ \\
\hline
\end{tabular}

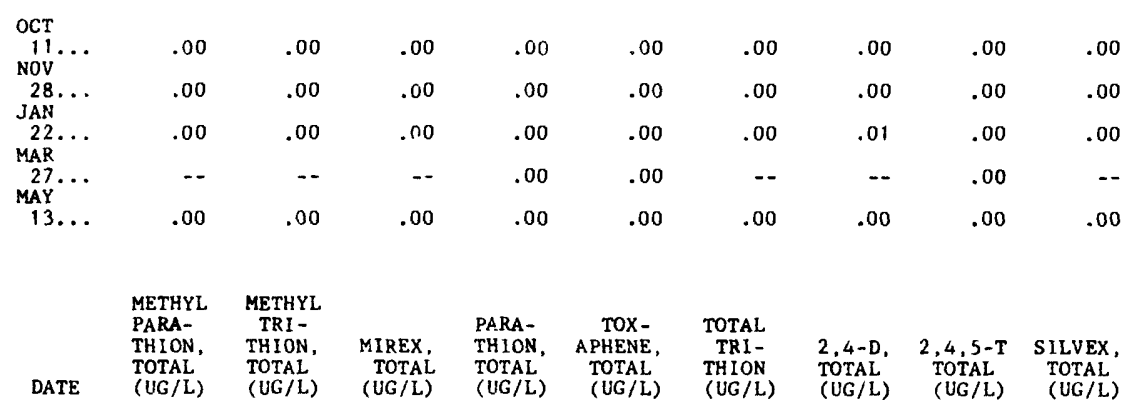

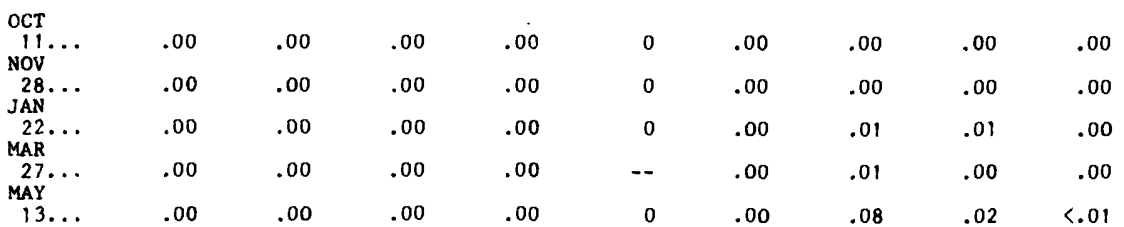


COLORADO RIVER BASIN

08159170 BIG SANDY CREEK NEAR ELGIN, TX--Continued

WATER QUALITY DATA, WATER YEAR OCTOBER 1979 TO SEPTEMBER 1980

\begin{tabular}{|c|c|c|c|c|c|c|c|}
\hline DATE & TIME & $\begin{array}{l}\text { STREAM- } \\
\text { FLOW, } \\
\text { INSTAN- } \\
\text { TANEOUS } \\
\text { (CFS) }\end{array}$ & $\begin{array}{c}\text { TEMPER - } \\
\text { AT URE, } \\
\text { WATER } \\
\text { (DEG C) }\end{array}$ & $\begin{array}{l}\text { SEDI- } \\
\text { MENT, } \\
\text { SUS- } \\
\text { PENDED } \\
\text { (MG / L) }\end{array}$ & $\begin{array}{l}\text { SEDI- } \\
\text { MENT } \\
\text { DIS- } \\
\text { CHARGE, } \\
\text { SUS- } \\
\text { PENDED } \\
\text { (T/DAY) }\end{array}$ & $\begin{array}{l}\text { SED. } \\
\text { SUSP. } \\
\text { FALL } \\
\text { DIAM. } \\
\% \text { FINER } \\
\text { THAN } \\
.002 \text { MM }\end{array}$ & $\begin{array}{l}\text { SED. } \\
\text { SUSP. } \\
\text { FALL } \\
\text { DIAM. } \\
\% \text { FINER } \\
\text { THAIl } \\
.004 \text { MM }\end{array}$ \\
\hline \multicolumn{8}{|l|}{ OCT } \\
\hline $\begin{array}{l}11 \ldots \\
\text { nov }\end{array}$ & 1110 & .30 & 16.0 & 10 & .01 & -- & - \\
\hline $28 \ldots$ & 1100 & 1.3 & 11.0 & 25 & .09 & $\sim$ & -- \\
\hline $09 \ldots$ & 1110 & .69 & 8.5 & 22 & .04 & -- & -- \\
\hline \\
\hline $27 \ldots$ & -. & 216 & -- & 841 & 490 & -- & -- \\
\hline $27 \ldots$ & 1510 & 178 & 15.0 & 1280 & 615 & 63 & 65 \\
\hline $28 \ldots$ & & 488 & & 1270 & 1670 & - & - \\
\hline $28 \ldots$ & 1130 & 265 & 15.5 & 1240 & 887 & -- & -- \\
\hline \multicolumn{8}{|l|}{ MAY } \\
\hline $12 \ldots$ & - & 8.3 & -- & 373 & 8.4 & - & $\cdots$ \\
\hline $12 \ldots$ & 2200 & 27 & -- & 2100 & 153 & 41 & 42 \\
\hline $13 \ldots$ & - & 205 & -- & 1050 & 581 & -- & - \\
\hline $13 \ldots$ & 0015 & 43 & -- & 851 & 99 & 61 & 73 \\
\hline $13 \ldots$ & 0300 & 54 & -- & 754 & 110 & -- & -- \\
\hline $14 \ldots$ & & 1000 & -- & 614 & 1660 & -- & - \\
\hline & 1400 & 1000 & 21.5 & 438 & 1180 & -. & -. \\
\hline
\end{tabular}

\begin{tabular}{|c|c|c|c|c|c|c|c|}
\hline DATE & $\begin{array}{c}\text { SED. } \\
\text { SUSP. } \\
\text { FALL } \\
\text { DIAM. } \\
\% \text { FINER } \\
\text { THAN } \\
.008 \mathrm{MM}\end{array}$ & $\begin{array}{l}\text { SED. } \\
\text { SUSP. } \\
\text { FALL } \\
\text { DIAM. } \\
\% \text { FIINER } \\
\text { THAN } \\
.016 \mathrm{MTM}\end{array}$ & $\begin{array}{l}\text { SED. } \\
\text { SUSP. } \\
\text { FALL } \\
\text { DIAM. } \\
\% \text { FINER } \\
\text { THAI } \\
.031 \mathrm{MM}\end{array}$ & $\begin{array}{c}\text { SED. } \\
\text { SUSP. } \\
\text { SIEVE } \\
\text { DIAM. } \\
\% \text { FINER } \\
\text { THAN } \\
.062 \text { MM }\end{array}$ & $\begin{array}{l}\text { SED. } \\
\text { SUSP. } \\
\text { SIEVE } \\
\text { DIAM. } \\
\% \text { FINER } \\
\text { THAN } \\
.125 \text { MM }\end{array}$ & $\begin{array}{l}\text { SED. } \\
\text { SUSP. } \\
\text { SIEVE } \\
\text { DIAM. } \\
\% \text { FINER } \\
\text { THAN } \\
.250 \mathrm{MM}\end{array}$ & $\begin{array}{c}\text { SED. } \\
\text { SUSP. } \\
\text { SIEVE } \\
\text { DIAM. } \\
\% \text { EINER } \\
\text { THAN } \\
.500 \text { MM }\end{array}$ \\
\hline OCT & & & & & & & \\
\hline $11 \ldots$ & -- & - & - & -- & -- & -- & $\ldots$ \\
\hline $28 \ldots$ & - & -- & -- & -- & - & -- & - \\
\hline $09 \ldots$ & $\rightarrow$ & - & -- & -- & -- & -- & -- \\
\hline$\underset{\operatorname{MAR}}{23} \cdots$ & $-\infty$ & -- & -- & $\cdots$ & $\cdots$ & -- & -- \\
\hline $27 \ldots$ & -- & -- & -- & -- & -- & -- & -- \\
\hline $27 \ldots$ & 69 & 75 & 81 & 85 & 90 & 95 & 99 \\
\hline $28 \ldots$ & -- & -- & -- & -- & -- & -- & - \\
\hline $\begin{array}{r}28 \\
\text { MAY }\end{array}$ & -- & -- & -- & - & -- & -- & - \\
\hline $12 \ldots$ & - & -- & - & -- & -- & -- & -- \\
\hline $12 \ldots$ & 43 & 52 & 65 & 95 & 96 & 98 & 99 \\
\hline $13 \ldots$ & $\bar{r}$ & 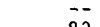 & 25 & $-\overline{7}$ & $-\overline{-}$ & $\overline{0}$ & $-\overline{-}$ \\
\hline $13 \ldots$ & 76 & 83 & 85 & 87 & 92 & 97 & 99 \\
\hline $13 \ldots$ & -- & $=$ & -- & 74 & 78 & 83 & 85 \\
\hline 14 & -- & 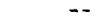 & - & - & $=-$ & -- & -- \\
\hline $14 \ldots$ & -- & -- & -- & 67 & 74 & 86 & 99 \\
\hline
\end{tabular}


10.0 SUPPLEMENTAL DATA--Continued

10.3 Water-Quality and Sediment Analysis at Streamflow Sites--Continued

COLORADO RIVER BASIN

08159170 BIG SANDY CREEK NEAR ELGIN, TX--Continued

WATER-QUALITY RECORDS PERIOD OF RECORD,--Chemical, biochemical, and pesticide analyses: May 1979 to September 1981 (discontinued).
Radiochemical analyses: May to September 1979.

WATER QUALITY DATA, WATER YEAR OCTOBER 1980 TO SEPTEMBER 1981

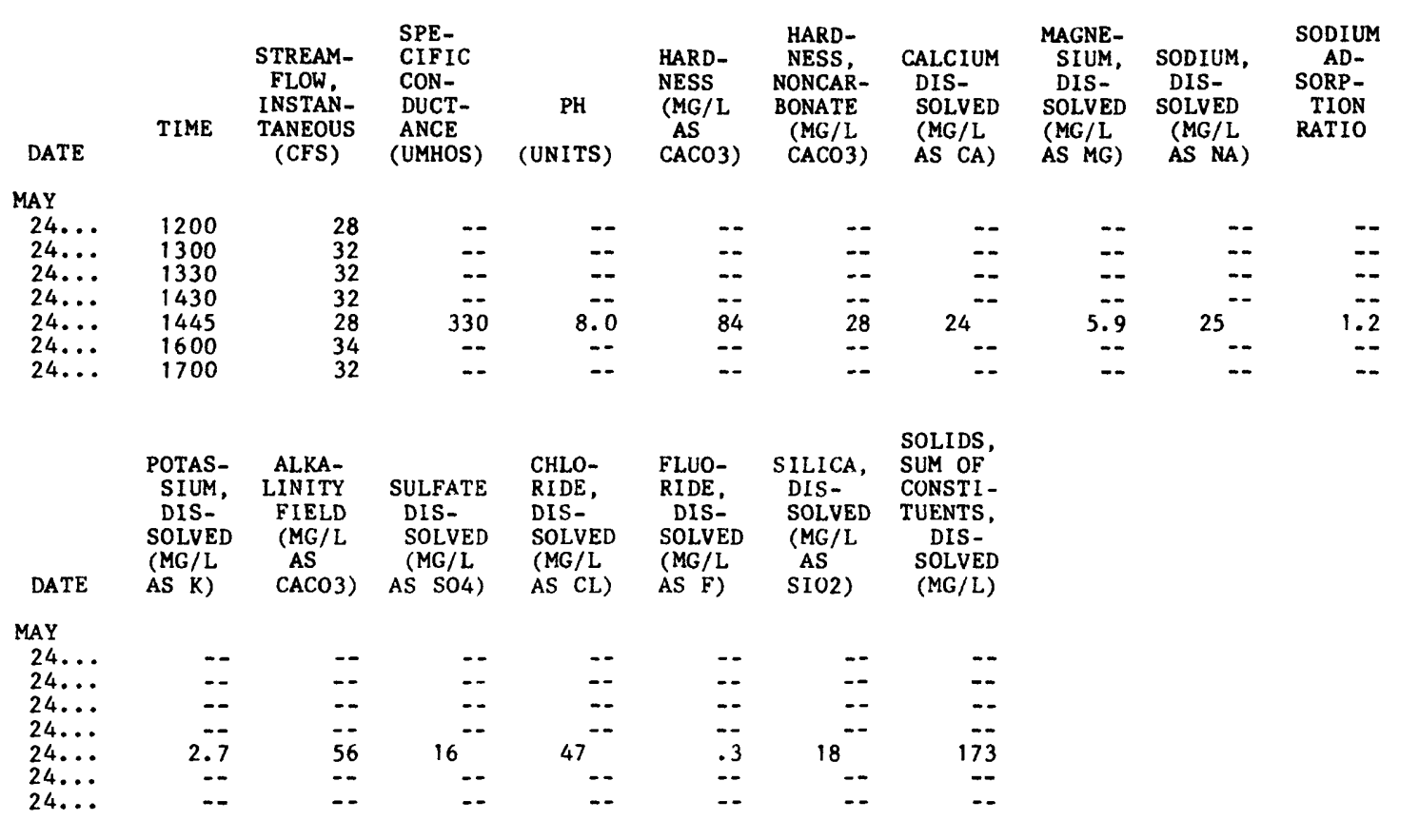




\subsection{SUPPLEMENTAL DATA--Cont inued \\ 10.3 Water-Quality and Sediment Analysis at Streamflow Sites--Continued}

COLORADO RIVER BASIN

08159180 DOGWOOD CREEK NEAR MCDADE, TX LOCATION.--Lat $30^{\circ} 14^{\prime} 29^{\prime \prime}$, long $97^{\circ} 17^{\prime} 03^{\prime \prime}$. Bast: 'p County, Hydrologic Unit 12090301, at upstream side of culvert
on unnamed gravel road in Camp Swift, $4 \mathrm{mi}(6 \mathrm{~km})$ southwest of McDade, and $9^{\text {mi }}\left(6^{\mathrm{k} m}\right)$ north of Bastrop. DRAINAGE AREA. $--0.53 \mathrm{mi}^{2}\left(1.37 \mathrm{~km}^{2}\right)$.

PERIOD OF RECORD.--Chemical, biochemical, pesticide, and sediment analyses: January to September 1980.

WATER QUALITY DATA, WATER YEAR OCTOBER 1979 TO SEPTEMBER 1980

\begin{tabular}{|c|c|c|c|c|c|c|c|c|c|c|}
\hline DATE & TIME & $\begin{array}{l}\text { STREAM- } \\
\text { FLOW } \\
\text { INSTAN- } \\
\text { TANEOUS } \\
\text { (CFS) }\end{array}$ & $\begin{array}{l}\text { SPE- } \\
\text { CIFIC } \\
\text { CON- } \\
\text { DUCT- } \\
\text { ANCE } \\
\text { (MICKO- } \\
\text { MHOS) }\end{array}$ & $\begin{array}{c}\text { PH } \\
\text { FIELD } \\
\text { (UNYTS) }\end{array}$ & $\begin{array}{l}\text { TEMPER- } \\
\text { ATURE, } \\
\text { WATER } \\
\text { (DEG C) }\end{array}$ & $\begin{array}{l}\text { COLOR } \\
\text { (PLAT- } \\
\text { INUM } \\
\text { COBALT } \\
\text { UNITS) }\end{array}$ & $\begin{array}{l}\text { TUR- } \\
\text { BID- } \\
\text { ITY } \\
\text { (NTU) }\end{array}$ & $\begin{array}{c}\text { OXYGEN, } \\
\text { DIS- } \\
\text { SOLVED } \\
\text { (MG/L) }\end{array}$ & $\begin{array}{c}\text { OXYGEN, } \\
\text { DIS- } \\
\text { SOLVED } \\
\text { (PER- } \\
\text { CENT } \\
\text { SATUR- } \\
\text { ATION) }\end{array}$ & $\begin{array}{c}\text { OXYGEN } \\
\text { DEMAND, } \\
\text { BIOCHEM } \\
\text { UNINIIB } \\
5 \text { DAY } \\
(M G / L)\end{array}$ \\
\hline $\begin{array}{r}\text { JAN } \\
22 \ldots \\
22 \ldots \\
22 \ldots \\
\text { MAR }\end{array}$ & $\begin{array}{l}0715 \\
0738 \\
1500\end{array}$ & $\begin{array}{l}13 \\
15 \\
1.5\end{array}$ & $\begin{array}{l}59 \\
59 \\
75\end{array}$ & $\begin{array}{l}7.2 \\
7.2 \\
7.7\end{array}$ & $11 . \overline{-}$ & $\begin{array}{l}400 \\
200 \\
200\end{array}$ & $\begin{array}{r}75 \\
260 \\
32\end{array}$ & $9 . \overline{7}$ & $=-$ & $\begin{array}{l}5.6 \\
4.6 \\
1.9\end{array}$ \\
\hline $\begin{array}{r}\text { MAR } \\
27 \ldots \\
27 \ldots \\
27 \ldots \\
27 \ldots \\
27 \ldots\end{array}$ & $\begin{array}{l}1000 \\
1022 \\
1600 \\
1806 \\
1810\end{array}$ & $\begin{array}{l}18 \\
28 \\
12 \\
4.9 \\
4.4\end{array}$ & $\begin{array}{l}-- \\
45 \\
- \\
61\end{array}$ & $\begin{array}{l}-- \\
-- \\
-- \\
7.4\end{array}$ & $\begin{array}{r}-. \\
15.0 \\
15.0 \\
15.0\end{array}$ & $\begin{array}{r}200 \\
250 \\
-- \\
200\end{array}$ & $\begin{array}{r}370 \\
400 \\
\\
130^{--}\end{array}$ & $\begin{array}{r}-- \\
-- \\
10.2\end{array}$ & $\begin{array}{l}-- \\
-- \\
--\end{array}$ & $\begin{array}{r}5.0 \\
4.6 \\
-- \\
-- \\
3.8\end{array}$ \\
\hline $\begin{array}{r}\text { MAY } \\
13 \ldots \\
13 \ldots \\
13 \ldots \\
13 \ldots \\
13 \ldots \\
14 \ldots\end{array}$ & $\begin{array}{l}1530 \\
1545 \\
1600 \\
1615 \\
1630 \\
1214\end{array}$ & $\begin{array}{l}9.9 \\
27 \\
54 \\
51 \\
44 \\
1.5\end{array}$ & $\begin{array}{l}58 \\
37 \\
37 \\
39 \\
43 \\
--\end{array}$ & $\begin{array}{l}-- \\
7.1 \\
-- \\
--\end{array}$ & $\begin{array}{l}-- \\
-- \\
-- \\
-- \\
--\end{array}$ & $\begin{array}{r}200 \\
160 \\
- \\
- \\
100 \\
\ldots\end{array}$ & 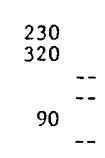 & $\begin{array}{l}-- \\
-- \\
-- \\
--\end{array}$ & $\begin{array}{l}-- \\
-- \\
-- \\
--\end{array}$ & $\begin{array}{r}-- \\
4.5 \\
-- \\
4.2 \\
3.9 \\
-.\end{array}$ \\
\hline DATE & $\begin{array}{c}\text { COLI- } \\
\text { FORI } \\
\text { TOTAL, } \\
\text { IMMED. } \\
\text { (COLS. } \\
\text { PER } \\
100 \mathrm{ML} \text { ) }\end{array}$ & $\begin{array}{l}\text { COLI- } \\
\text { FORM, } \\
\text { FECAL, } \\
0.7 \\
\text { (MM-MF } \\
\text { (COLS./ } \\
100 \text { ML) }\end{array}$ & $\begin{array}{l}\text { STRFP- } \\
\text { TOCOCCI } \\
\text { FECAL, } \\
\text { KF ACAK } \\
\text { (COLS. } \\
\text { PER } \\
100 \mathrm{ML} \text { ) }\end{array}$ & $\begin{array}{l}\text { HARD- } \\
\text { NESS } \\
\text { (MC/L } \\
\text { AS } \\
\text { CACO3) }\end{array}$ & $\begin{array}{l}\text { HARD- } \\
\text { NESS } \\
\text { NONCAR- } \\
\text { BONATE } \\
\text { (MG/L } \\
\text { CACO3) }\end{array}$ & $\begin{array}{l}\text { CALCIUM } \\
\text { DIS- } \\
\text { SOLVED } \\
\text { (MG/L } \\
\text { AS CA) }\end{array}$ & $\begin{array}{l}\text { MAGHE- } \\
\text { SIUM, } \\
\text { DIS- } \\
\text { SOLVED } \\
\text { (MG/L } \\
\text { AS MG) }\end{array}$ & $\begin{array}{l}\text { SODIUM, } \\
\text { DIS- } \\
\text { SOLVED } \\
\text { (MG/L } \\
\text { AS NA) }\end{array}$ & $\begin{array}{l}\text { SODIUM } \\
\text { AD- } \\
\text { SORP- } \\
\text { TION } \\
\text { RATIO }\end{array}$ & $\begin{array}{l}\text { POTAS- } \\
\text { SIUM, } \\
\text { DIS- } \\
\text { SOLVED } \\
\text { (MG/L } \\
\text { AS K) }\end{array}$ \\
\hline $\begin{array}{l}\text { JAN } \\
22 \ldots \\
22 \ldots \\
22 \ldots \\
\text { MAR }\end{array}$ & $\begin{array}{l}-- \\
--\end{array}$ & $\begin{array}{l}-- \\
-- \\
--\end{array}$ & $\begin{array}{l}-- \\
--\end{array}$ & $\begin{array}{l}20 \\
17 \\
31\end{array}$ & $\begin{array}{l}0 \\
0 \\
0\end{array}$ & $\begin{array}{l}5.3 \\
4.6 \\
8.5\end{array}$ & $\begin{array}{l}1.6 \\
1.3 \\
2.3\end{array}$ & $\begin{array}{l}4.8 \\
4.1 \\
3.1\end{array}$ & $\begin{array}{l}.5 \\
.4 \\
.2\end{array}$ & $\begin{array}{l}5.0 \\
4.9 \\
3.9\end{array}$ \\
\hline $\begin{array}{l}27 \ldots \\
27 \ldots \\
27 \ldots \\
27 \ldots \\
27 \ldots\end{array}$ & $\begin{array}{r}-- \\
-- \\
4500\end{array}$ & $\begin{array}{r}-- \\
-- \\
-- \\
2600\end{array}$ & $\begin{array}{r}-- \\
- \\
- \\
17000\end{array}$ & $\begin{array}{l}-- \\
-- \\
-- \\
--\end{array}$ & $\begin{array}{l}-- \\
-- \\
-- \\
--\end{array}$ & $\begin{array}{l}-- \\
-- \\
-- \\
--\end{array}$ & $\begin{array}{l}-- \\
-- \\
-- \\
--\end{array}$ & $\begin{array}{l}-- \\
-- \\
-- \\
--\end{array}$ & $\begin{array}{l}-- \\
-- \\
-- \\
--\end{array}$ & $\begin{array}{l}-- \\
-- \\
--\end{array}$ \\
\hline $\begin{array}{r}\text { MAY } \\
13 \ldots \\
13 \ldots \\
13 \ldots \\
13 \ldots \\
13 \ldots \\
14 \ldots\end{array}$ & $\begin{array}{l}-- \\
-- \\
-- \\
--\end{array}$ & $\begin{array}{l}-- \\
-- \\
-- \\
-- \\
--\end{array}$ & $\begin{array}{l}-- \\
-- \\
-- \\
-- \\
--\end{array}$ & $\begin{array}{l}-- \\
\overline{14} \\
\cdots- \\
--\end{array}$ & $\begin{array}{l}-- \\
-- \\
0 \\
-- \\
--\end{array}$ & $\begin{array}{r}-- \\
-- \\
3.9 \\
-- \\
--\end{array}$ & $\begin{array}{l}-- \\
-- \\
1.1 \\
-- \\
--\end{array}$ & $\begin{array}{r}-- \\
2.5 \\
-- \\
--\end{array}$ & $\begin{array}{l}-- \\
- \\
.3 \\
-- \\
--\end{array}$ & $\begin{array}{l}-- \\
3.2 \\
-- \\
-- \\
--\end{array}$ \\
\hline DATE & $\begin{array}{c}\text { BICAR- } \\
\text { BONATE } \\
\text { (MG/L } \\
\text { AS } \\
\text { HCO3) }\end{array}$ & $\begin{array}{c}\text { CAR- } \\
\text { BONATE } \\
\text { (MG/L } \\
\text { AS CO3) }\end{array}$ & $\begin{array}{l}\text { SULFATE } \\
\text { DIS- } \\
\text { SOLVED } \\
\text { (MG/L } \\
\text { AS SO4) }\end{array}$ & $\begin{array}{l}\text { CHLO- } \\
\text { RIDE, } \\
\text { DIS- } \\
\text { SOLVED } \\
\text { (MG/L } \\
\text { AS CL) }\end{array}$ & $\begin{array}{l}\text { FLUO- } \\
\text { RIDE, } \\
\text { DIS- } \\
\text { SOLVED } \\
\text { (MG/L } \\
\text { AS F) }\end{array}$ & $\begin{array}{l}\text { SILICA, } \\
\text { DIS- } \\
\text { SOLVED } \\
\text { (MG/L } \\
\text { AS } \\
\text { SIO2) }\end{array}$ & $\begin{array}{c}\text { SOLIDS, } \\
\text { SUM OF } \\
\text { CONSTI- } \\
\text { TUENTS, } \\
\text { DIS - } \\
\text { SOLVED } \\
\text { (MG/L) }\end{array}$ & $\begin{array}{c}\text { NITRO- } \\
\text { GEN, } \\
\text { NITRATE } \\
\text { TOTAL } \\
\text { (MG/L } \\
\text { AS N) }\end{array}$ & $\begin{array}{c}\text { NITRO- } \\
\text { GEN, } \\
\text { NITRITE } \\
\text { TOTAL } \\
(M G / L \\
\text { AS N) }\end{array}$ & $\begin{array}{c}\text { NITRO- } \\
\text { GEN } \\
\text { NO2+NO3 } \\
\text { TOTAL } \\
\text { (MC/L } \\
\text { AS N) }\end{array}$ \\
\hline
\end{tabular}

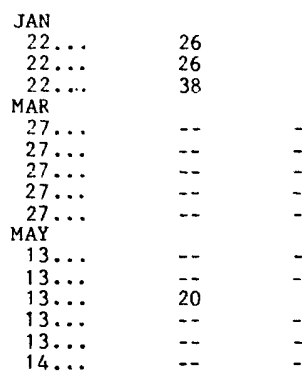

$\begin{array}{cc}0 & 14 \\ 0 & 2.1 \\ 0 & 6.0 \\ -- & -- \\ -- & - \\ \therefore- & \therefore \\ -- & - \\ -- & - \\ -- & - \\ 0 & 2.9 \\ -- & - \\ -- & -\end{array}$

2.3
2.2
4.3
2.2
2.5
.--
2.5
.-
-.5
.-
--
-

\begin{tabular}{l}
.2 \\
.2 \\
.1 \\
-- \\
$-ב$ \\
-- \\
-- \\
-- \\
-- \\
\hline 0 \\
-- \\
--
\end{tabular}

13
9.1
8.5
--
--
--
--
--
5.8
--
--
--

$\begin{array}{rrrr}60 & .12 & .010 & .13 \\ 42 & .11 & .010 & .12 \\ 56 & .02 & .010 & .03 \\ & & & \\ -- & .14 & .010 & .15 \\ -- & .15 & .010 & .16 \\ -- & -- & -- & - \\ -- & -- & -- & -. \\ -- & .05 & .010 & .06 \\ -- & .07 & .010 & .08 \\ -- & .09 & .010 & .10 \\ 32 & -- & \ldots- & - \\ -- & -- & -- & .05 \\ -- & .04 & .010 & .05 \\ -- & -. & -- & .-\end{array}$ 
10.0 SUPPLEMENTAL DATA--Continued

10.3 Water-Quality and Sediment Analysis at Streamflow Sites--Continued

COLORADO RIVER BASIN

08159180 DOGWOOD CREEK NEAR MCDADE, TX--Continued

WATER QUALITY DATA, WATER YEAR OCTOBER 1979 TO SEPTEMBER 1980

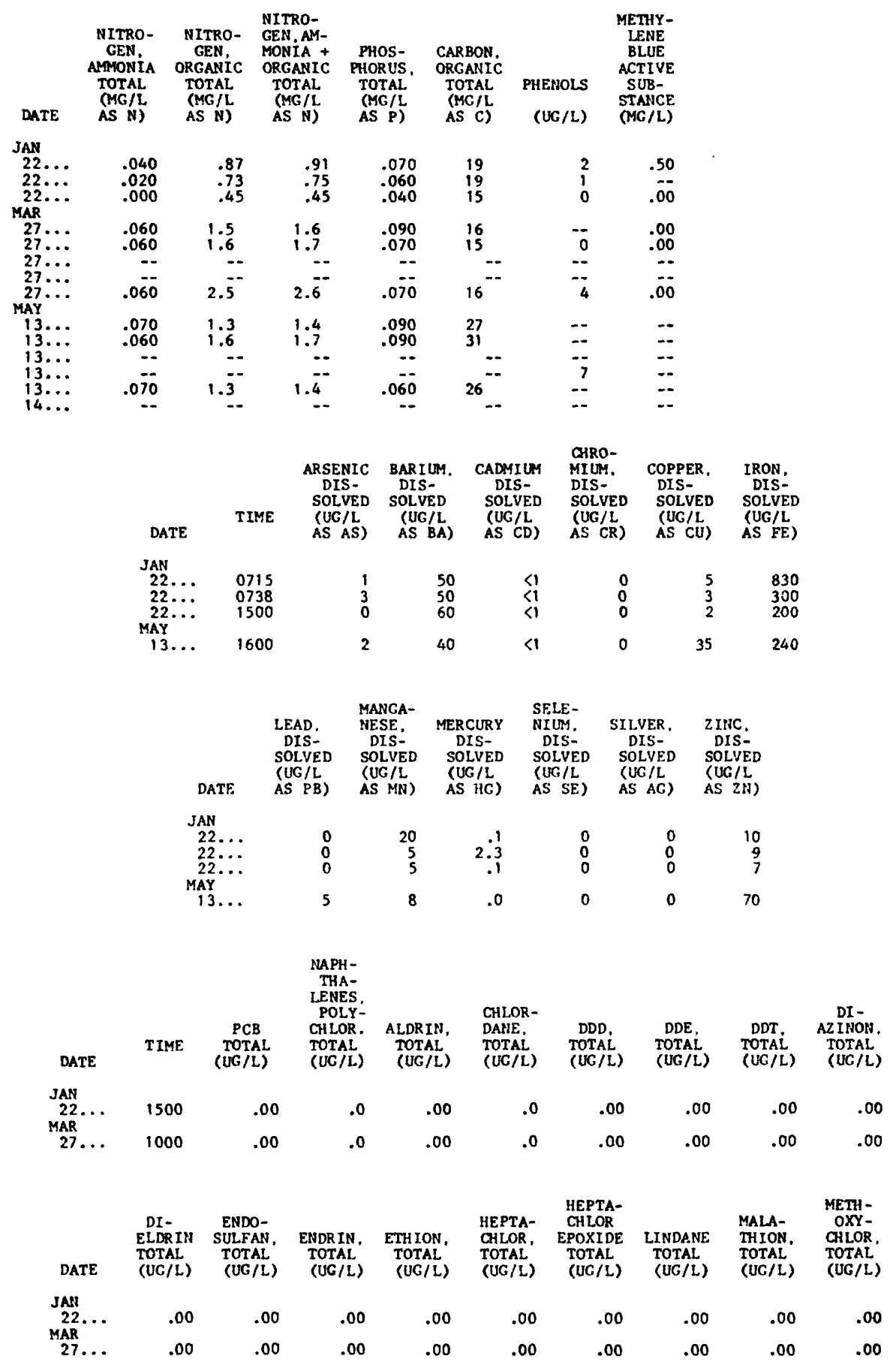




\subsection{SUPPLEMENTAL DATA--Continued}

10.3 Water-Quality and Sediment Analysis at Streamflow Sites--Continued

COLORADO RIVER BASIN

O8159180 DOGWOOD CREEK NEAR MCDADE, TX--Continued

WATER QUALITY DATA, WATER YEAR OCTOBER 1979 TO SEPTEMBER 1980

\begin{tabular}{|c|c|c|c|c|c|c|c|c|c|}
\hline DATE & $\begin{array}{l}\text { METHYL } \\
\text { PARA- } \\
\text { THION, } \\
\text { TOTAL } \\
\text { (UG/L) }\end{array}$ & $\begin{array}{l}\text { METHYL } \\
\text { TRI - } \\
\text { THION, } \\
\text { TOTAL } \\
\text { (UG /L) }\end{array}$ & $\begin{array}{c}\text { MIREX, } \\
\text { TOTAL } \\
\text { (UG/L) }\end{array}$ & $\begin{array}{l}\text { PARA- } \\
\text { THION, } \\
\text { TOTAL } \\
\text { (UG/L) }\end{array}$ & $\begin{array}{l}\text { TOX- } \\
\text { APHENE, } \\
\text { TOTAL } \\
\text { (UG/L) }\end{array}$ & $\begin{array}{l}\text { TOTAL } \\
\text { TRI- } \\
\text { THION } \\
(U G / L)\end{array}$ & $\begin{array}{l}2,4-D \text {, } \\
\text { TOTAL. } \\
\text { (UG/L) }\end{array}$ & $\begin{array}{c}2,4,5-\mathrm{T} \\
\text { TOTAL } \\
\text { (UG/L) }\end{array}$ & $\begin{array}{c}\text { SILVEX, } \\
\text { TOTAL } \\
\text { (UG/L) }\end{array}$ \\
\hline \multirow[t]{14}{*}{$\begin{array}{l}\text { JAN } \\
22 \ldots \\
\text { MAR } \\
27 \ldots\end{array}$} & .00 & .00 & .00 & .00 & 0 & .00 & .00 & .00 & .00 \\
\hline & DATE & TIME & $\begin{array}{l}\text { STREAM- } \\
\text { FLOW, } \\
\text { INSTAN- } \\
\text { TANEOUS } \\
\text { (CFS) }\end{array}$ & $\begin{array}{l}\text { TEMPER- } \\
\text { ATURE. } \\
\text { HATER } \\
\text { (DEG C) }\end{array}$ & $\begin{array}{l}\text { SEDI- } \\
\text { MENT, } \\
\text { SUS- } \\
\text { PENDED } \\
\text { (MG/L) }\end{array}$ & $\begin{array}{l}\text { SEDI - } \\
\text { MENT } \\
\text { DIS- } \\
\text { CHARGE, } \\
\text { SUS- } \\
\text { PENDED } \\
\text { (T/DAY) }\end{array}$ & $\begin{array}{l}\text { SED. } \\
\text { SUSP. } \\
\text { FALL } \\
\text { DIAM. } \\
\% \text { FINER } \\
\text { THAN } \\
.002 \text { MM }\end{array}$ & $\begin{array}{l}\text { SED. } \\
\text { SUSP. } \\
\text { FALL } \\
\text { DIAM. } \\
\% \text { FINER } \\
\text { THAN } \\
.004 \text { MM }\end{array}$ & \\
\hline & $\begin{array}{r}\text { JAN } \\
22 \ldots \\
22 \ldots \\
\text { MAR }\end{array}$ & $\begin{array}{l}0715 \\
1500\end{array}$ & $\begin{array}{l}13 \\
1.5\end{array}$ & $11 . \overline{5}$ & $\begin{array}{l}594 \\
256\end{array}$ & $\begin{array}{r}21 \\
1.0\end{array}$ & $\begin{array}{l}92 \\
--\end{array}$ & $\begin{array}{l}95 \\
--\end{array}$ & \\
\hline & $\begin{array}{r}27 \ldots \\
27 \ldots \\
27 \ldots \\
27 \ldots \\
\text { MAY }\end{array}$ & $\begin{array}{l}1000 \\
1022 \\
1600 \\
1806\end{array}$ & $\begin{array}{c}18 \\
28 \\
12 \\
4.9\end{array}$ & $\begin{array}{r}-- \\
15.0 \\
15.0\end{array}$ & $\begin{array}{l}661 \\
404 \\
161 \\
109\end{array}$ & $\begin{array}{l}32 \\
31 \\
5.2 \\
1.4\end{array}$ & $\begin{array}{l}82 \\
-- \\
-- \\
--\end{array}$ & $\begin{array}{l}89 \\
-- \\
-- \\
--\end{array}$ & \\
\hline & $\begin{array}{l}13 \ldots \\
13 \ldots \\
13 \ldots \\
14 \ldots\end{array}$ & $\begin{array}{l}1530 \\
1545 \\
1630 \\
1214\end{array}$ & $\begin{array}{l}9.9 \\
27 \\
44 \\
1.5\end{array}$ & $\begin{array}{l}-- \\
-- \\
--\end{array}$ & $\begin{array}{r}114 \\
701 \\
63 \\
54\end{array}$ & $\begin{array}{c}3.0 \\
51 \\
7.5 \\
.22\end{array}$ & $\begin{array}{l}- \\
\cdots \\
-\end{array}$ & $\begin{array}{l}-- \\
-- \\
--\end{array}$ & \\
\hline & & $\begin{array}{l}\text { SED } \\
\text { SUSP. } \\
\text { FALL } \\
\text { DIAM. } \\
\% \text { FINER } \\
\text { THAN }\end{array}$ & $\begin{array}{l}\text { SED. } \\
\text { SUSP. } \\
\text { FAL1 } \\
\text { DIAM. } \\
\% \text { FINER } \\
\text { THAN }\end{array}$ & $\begin{array}{l}\text { SED. } \\
\text { SUSP. } \\
\text { FALI } \\
\text { DIAM. } \\
\% \text { FINER } \\
\text { THAN }\end{array}$ & $\begin{array}{l}\text { SED. } \\
\text { SUSP. } \\
\text { SIEVE } \\
\text { DIAM. } \\
\% \text { FINER } \\
\text { THAN }\end{array}$ & $\begin{array}{l}\text { SED } \\
\text { SUSP. } \\
\text { SIEVE } \\
\text { DIAM. } \\
\% \text { FINER } \\
\text { THIAN }\end{array}$ & $\begin{array}{l}\text { SED. } \\
\text { SUSP. } \\
\text { SIEVE } \\
\text { DIAM. } \\
\% \text { FINER } \\
\text { THAN }\end{array}$ & $\begin{array}{l}\text { SED. } \\
\text { SUSP. } \\
\text { SIEVE } \\
\text { DIAM. } \\
\% \text { FINER } \\
\text { THAN }\end{array}$ & \\
\hline & DATE & $.008 \mathrm{MN}$ & $.016 \mathrm{MP}$ & $.031 \mathrm{MM}$ & $.062 \mathrm{MM}$ & $.125 \mathrm{MM}$ & $.250 \mathrm{MM}$ & $.500 \mathrm{MM}$ & \\
\hline & JAN & & & & & & & & \\
\hline & $\begin{array}{r}22 \ldots \\
22 \ldots \\
M A R\end{array}$ & 96 & $\begin{array}{l}98 \\
--\end{array}$ & $\begin{array}{l}99 \\
-\cdots\end{array}$ & $\begin{array}{l}99 \\
99\end{array}$ & $\begin{array}{l}99 \\
99\end{array}$ & $\begin{array}{l}99 \\
99\end{array}$ & $\begin{array}{l}100 \\
100\end{array}$ & \\
\hline & $\begin{array}{l}27 \ldots \\
27 \ldots\end{array}$ & 90 & 96 & 97 & $\begin{array}{l}99 \\
98\end{array}$ & $\begin{array}{r}100 \\
99\end{array}$ & $\overline{99}$ & $10 \overline{0}$ & \\
\hline & $27 \ldots$ & -- & -- & -- & -- & -- & -- & -- & \\
\hline & $\underset{\text { MAY }}{27} \cdots$ & -- & -- & -- & -- & -- & -- & - & \\
\hline & $\begin{array}{l}13 \ldots \\
13 \ldots \\
13 \ldots\end{array}$ & $\begin{array}{l}-- \\
--\end{array}$ & $\begin{array}{l}-- \\
--\end{array}$ & $\begin{array}{l}-- \\
--\end{array}$ & $\begin{array}{l}89 \\
93 \\
98\end{array}$ & $\begin{array}{l}95 \\
98 \\
98\end{array}$ & $\begin{array}{l}99 \\
99 \\
99\end{array}$ & $\begin{array}{l}100 \\
100 \\
100\end{array}$ & \\
\hline & $14 \ldots$ & -- & -- & -- & -- & -- & -- & -- & \\
\hline
\end{tabular}




\subsection{SUPPLEMENTAL DATA--Continued \\ 10.3 Water-Quality and Sediment Analysis at Streamflow Sites--Continued}

COLORADO RIVER BASIN

08159185 DOGWOOD CREEK AT HICHWAY 95 NCAR MCDADE. TX

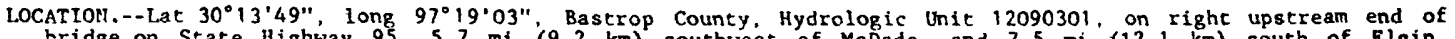
bridge on State Highway $95.5 .7 \mathrm{mi}(9.2 \mathrm{~km})$ southwest of McDade, and $7.5 \mathrm{mi}(12.1 \mathrm{~km}) \mathrm{south}$ of $\mathrm{Elgin}$. DRAINAGE AREA. $--5.03 \mathrm{mi}^{2}\left(13.03 \mathrm{~km}^{2}\right)$.

PERIOD OF RECORD.--Chemical, biochemical, pesticide, and sediment analyses: March to September 1980.

WATER QUALITY DATA. WATER. YEAR OCTOBER 1979 TO SEPTEMBER 1980

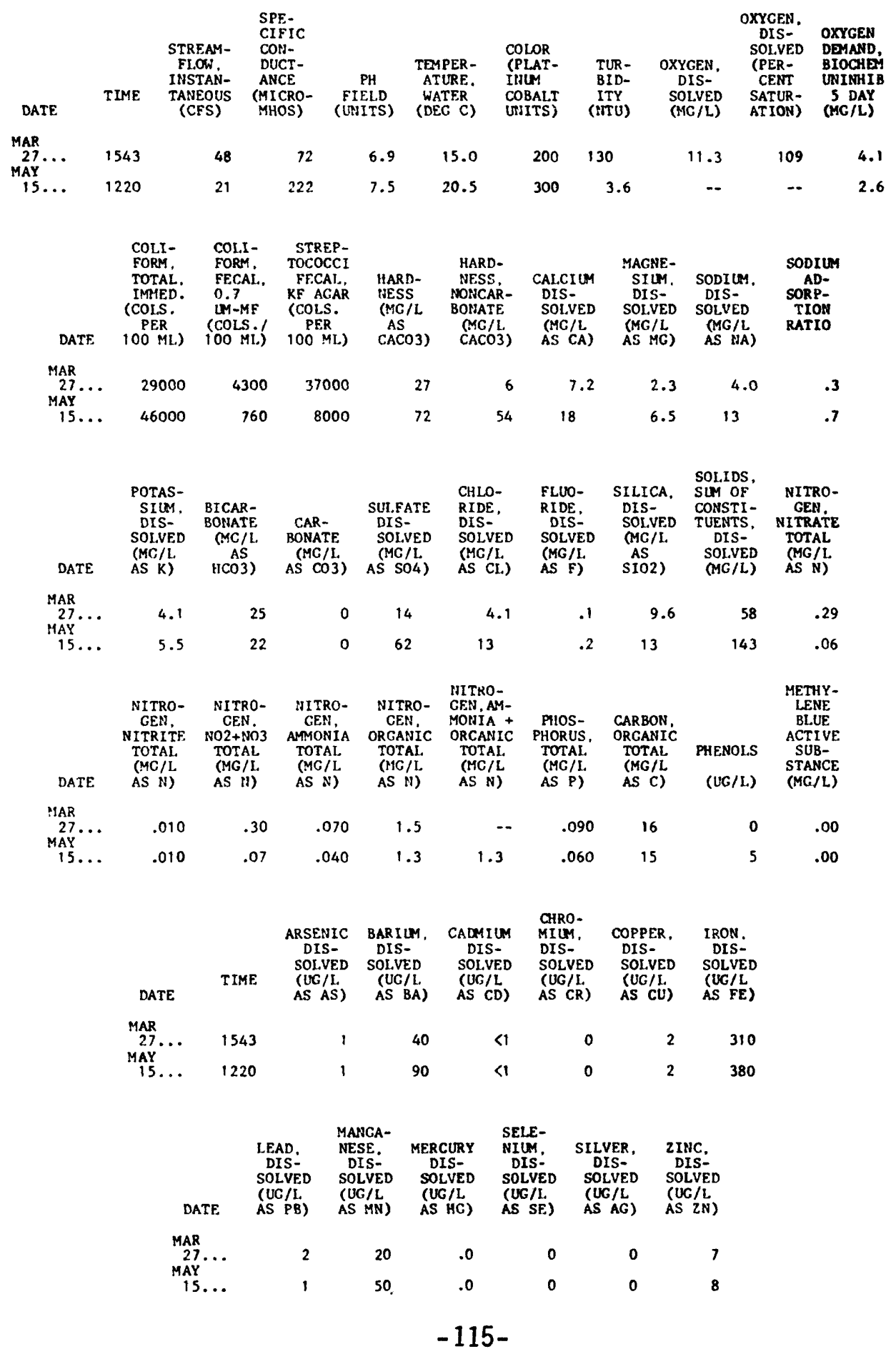




\subsection{SUPPLEMENTAL DATA--Continued}

10.3 Water-Quality and Sediment Analysis at Streamflow Sites--Continued

COLORADO RIVER BASIN

08159185 DOGWOOD CREEK AT HIGHWAY 95 NEAR MCDADE, TX--Continued

WATER QUALITY DATA. WATER YEAR OCTOBER 1979 TO SEPTEMBER 1980

\begin{tabular}{|c|c|c|c|c|c|c|c|c|}
\hline DATE & TIME & $\begin{array}{c}\text { ALDR IN, } \\
\text { TOTAL } \\
\text { (UG/L) }\end{array}$ & $\begin{array}{c}\text { DDE } \\
\text { TOTAL } \\
\text { (UG/L) }\end{array}$ & $\begin{array}{c}\text { DI- } \\
\text { AZ INON, } \\
\text { TOTAL } \\
\text { (UG/L) }\end{array}$ & $\begin{array}{l}\text { ETHION, } \\
\text { TOTAL } \\
\text { (UG/L) }\end{array}$ & $\begin{array}{l}\text { HEPTA- } \\
\text { CHLOR, } \\
\text { TOTAL } \\
\text { (UG/L) }\end{array}$ & $\begin{array}{l}\text { MALA- } \\
\text { THION, } \\
\text { TOTAL } \\
\text { (UG/L) }\end{array}$ & $\begin{array}{l}\text { METHYL } \\
\text { PARA- } \\
\text { TH ION, } \\
\text { TOTAL } \\
\text { (UG/L) }\end{array}$ \\
\hline \multicolumn{9}{|l|}{ MAR } \\
\hline $27 \ldots$ & 1543 & .00 & .00 & .00 & .00 & .00 & .00 & .00 \\
\hline
\end{tabular}

\begin{tabular}{|c|c|c|c|c|c|c|c|}
\hline DATE & $\begin{array}{l}\text { METHYL } \\
\text { TRI- } \\
\text { TH ION, } \\
\text { TOTAL } \\
\text { (UG } / L \text { ) }\end{array}$ & $\begin{array}{l}\text { MIREX, } \\
\text { TOTAL } \\
\text { (UC/L) }\end{array}$ & $\begin{array}{l}\text { PARA- } \\
\text { TH ION, } \\
\text { TUTAL } \\
\text { (UG/L) }\end{array}$ & $\begin{array}{l}\text { TOTAL } \\
\text { TRI- } \\
\text { THION } \\
\text { (UG/L) }\end{array}$ & $\begin{array}{l}2,4-\mathrm{D} \text {, } \\
\text { TOTAL } \\
\text { (UG/L) }\end{array}$ & $\begin{array}{l}2,4.5-\mathrm{T} \\
\text { TOTAL } \\
\text { (UG/L) }\end{array}$ & $\begin{array}{l}\text { SILVEX, } \\
\text { TOTAL } \\
\text { (UG/L) }\end{array}$ \\
\hline $\begin{array}{l}\text { IAR } \\
27 \ldots \ldots\end{array}$ & .00 & .00 & .00 & .00 & .01 & .00 & .00 \\
\hline
\end{tabular}


10.0 SUPPLEMENTAL DATA

10.4 Daily and Monthly Rainfall Values for Five Recording Rainfall Gages, 1980 and 1981 Water Years

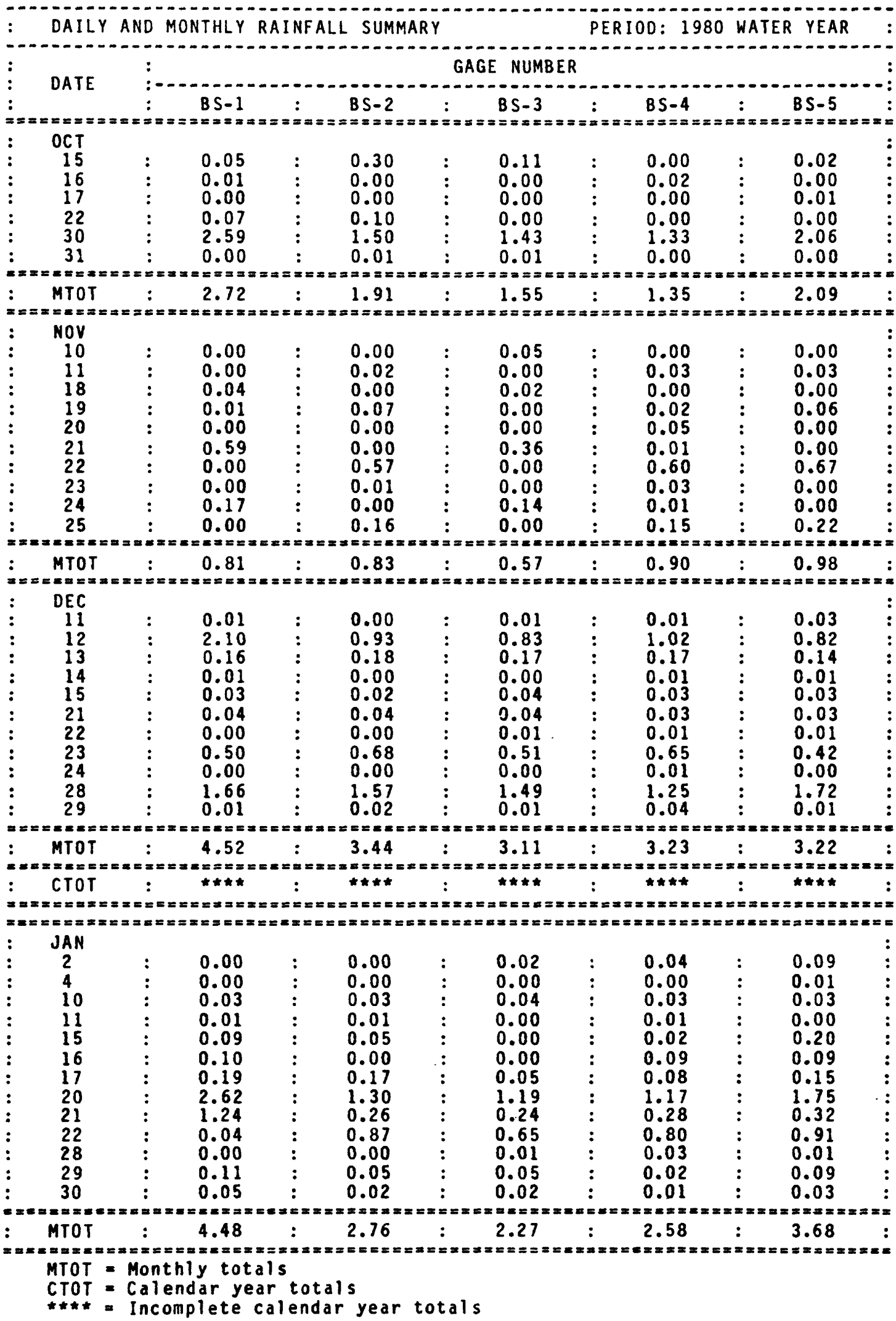


10.0 SUPPLEMENTAL DATA--Cont inued 10.4 Daily and Monthly Rainfall Values for Five Recording Rainfall Gages, 1980 and 1981 Water Years--Cont inued

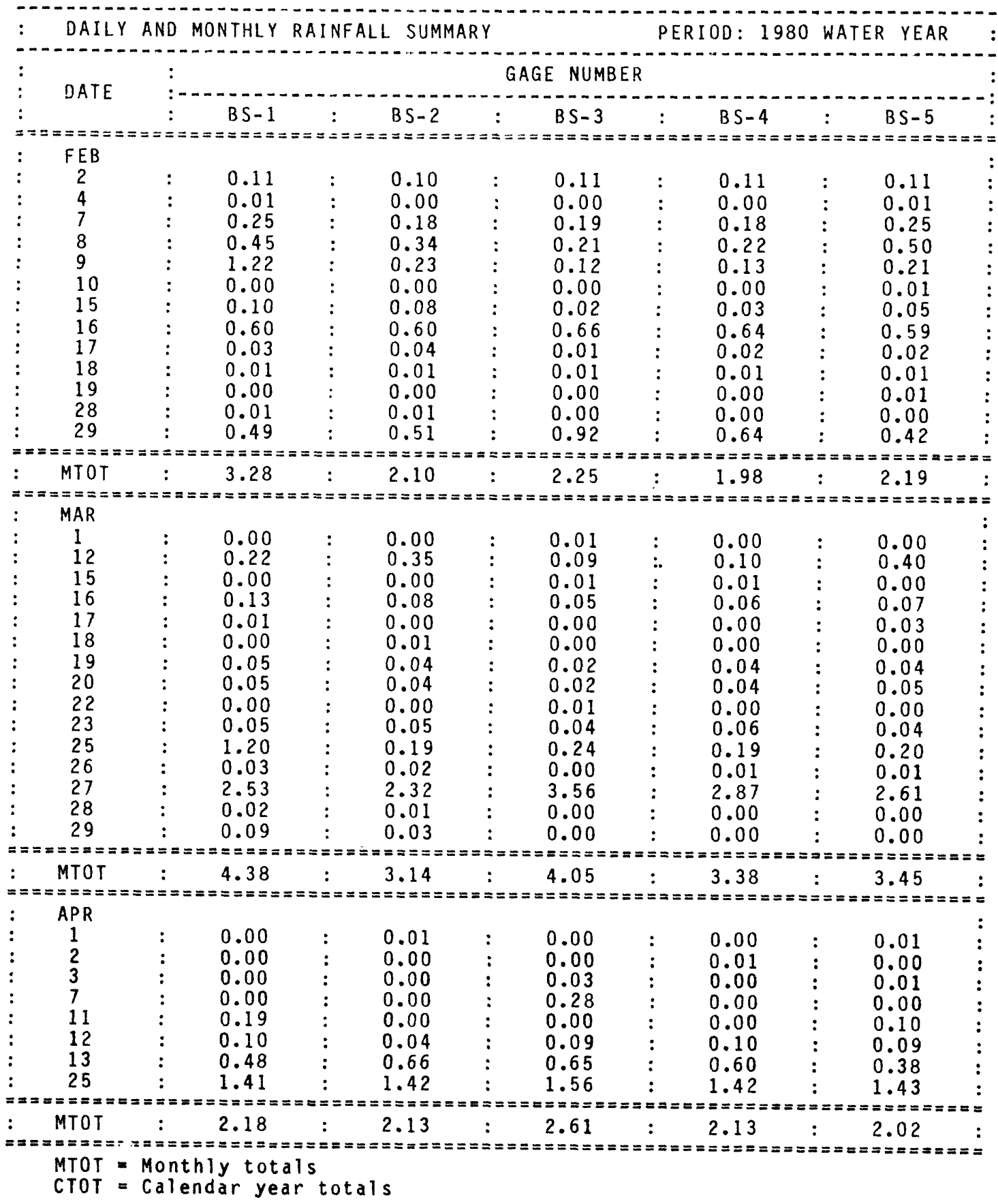


10.0 SUPPLEMENTAL DATA--Cont inued

10.4 Daily and Monthly Rainfall Values for Five Recording Rainfall Gages, 1980 and 1981 Water Years--Cont inued

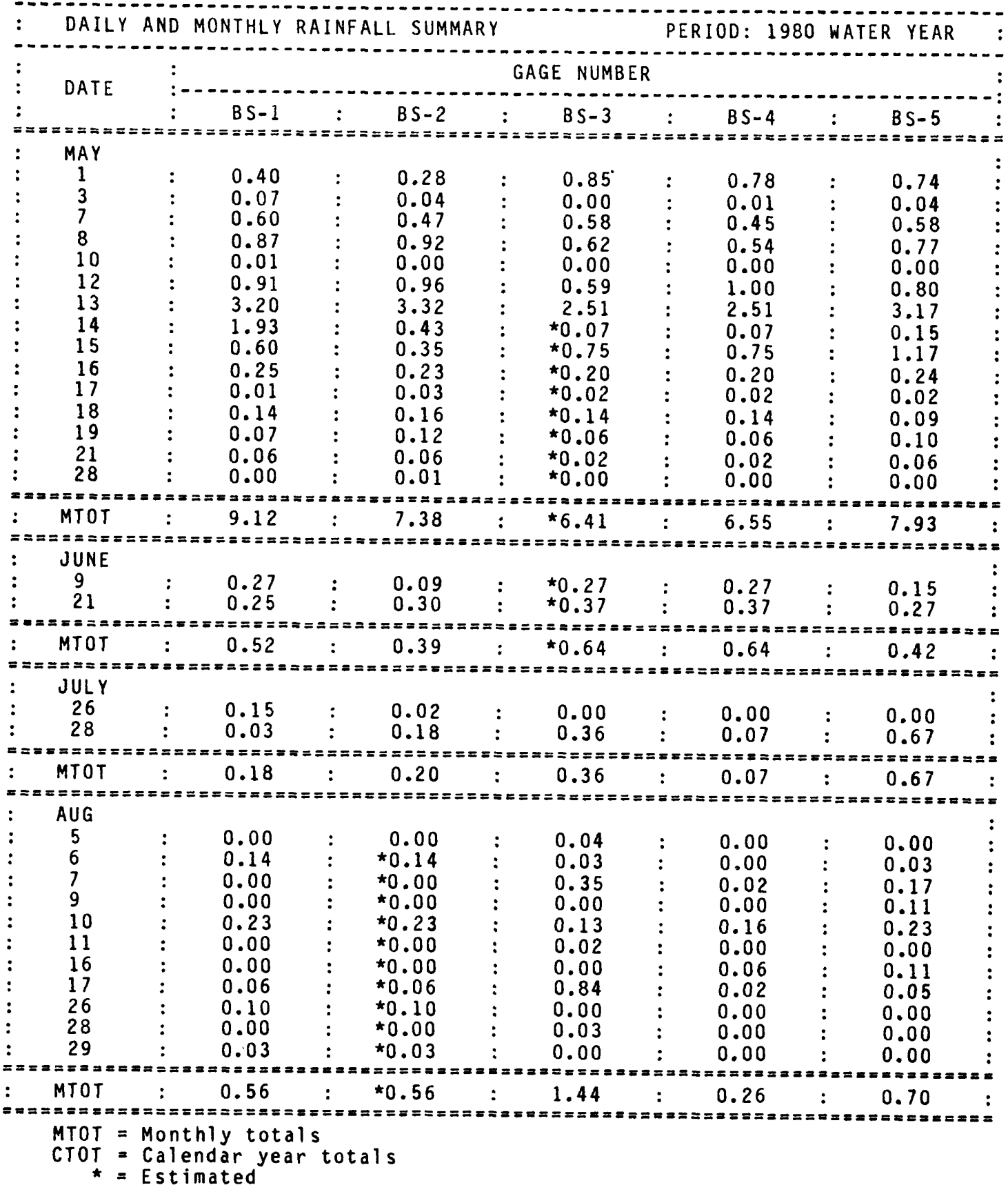


10.0 SUPPLEMENTAL DATA--Cont inued

10.4 Daily and Monthly Rainfall Values for Five Recording Rainfall Gages, 1980 and 1981 Water Years--Cont inued

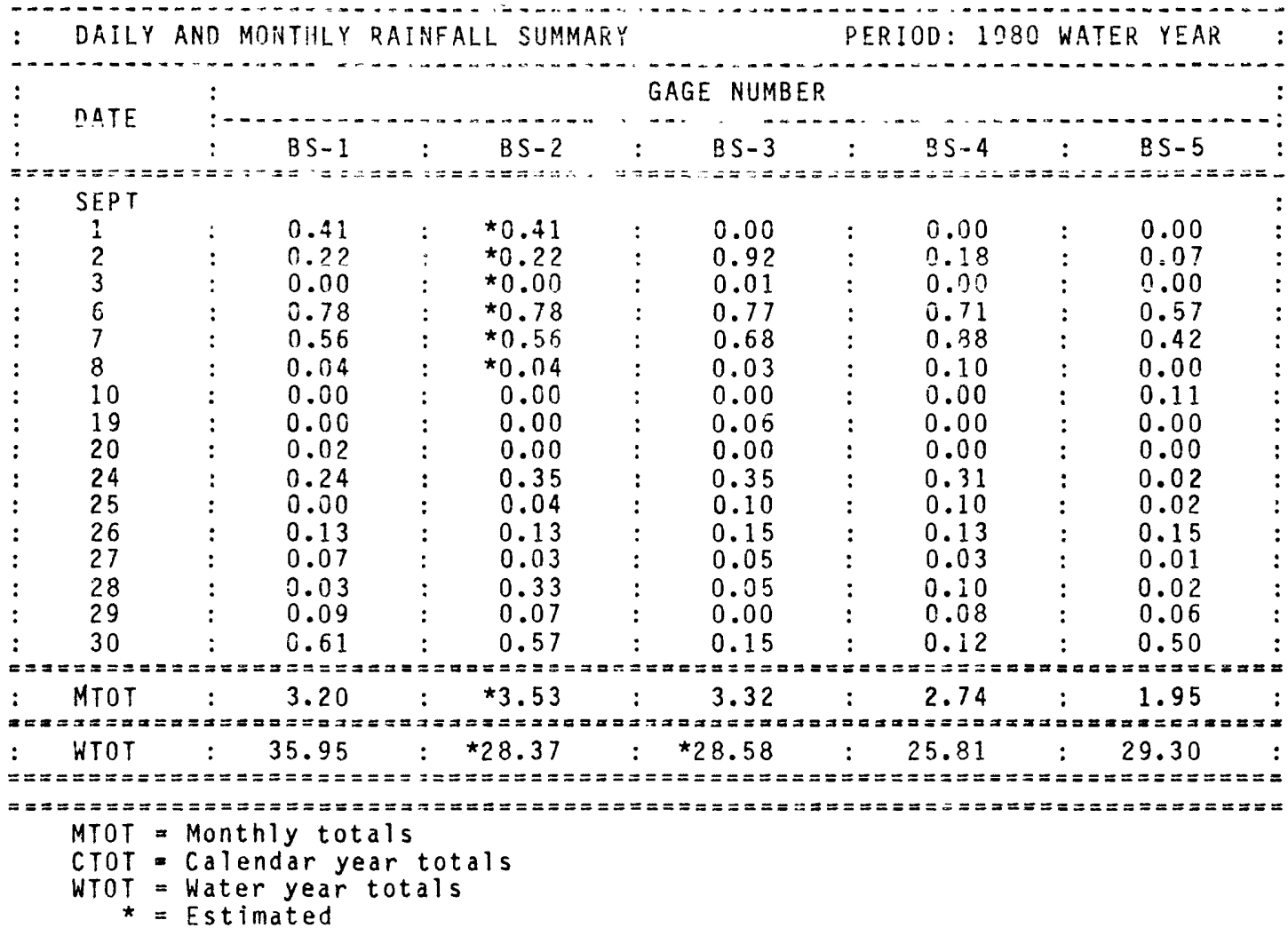


10.0 SUPPLEMENTAL DATA--Cont inued

10.4 Daily and Monthly Rainfall Values for Five Recording Rainfall Gages, 1980 and 1981 Water Years--Cont inued

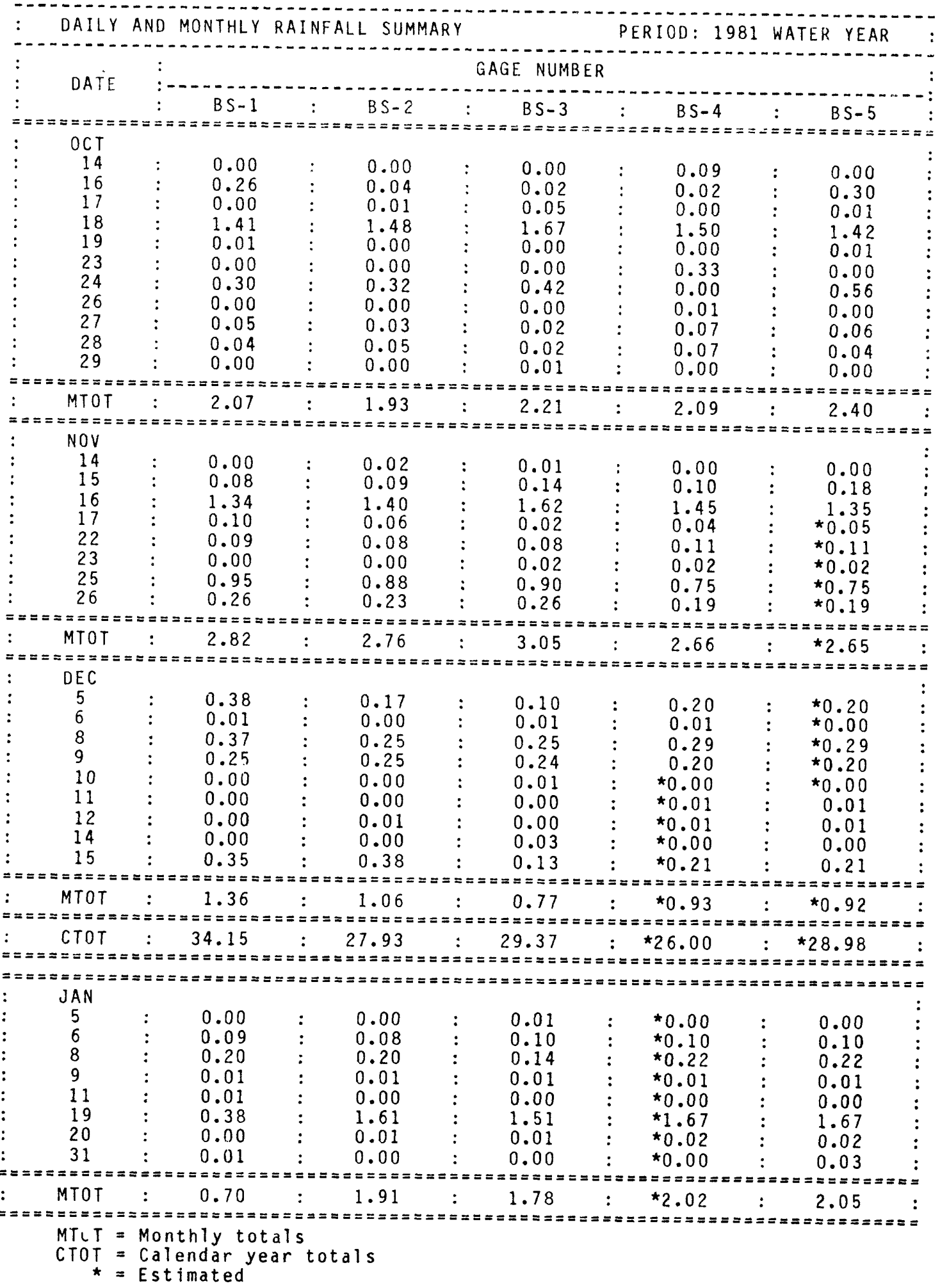


10.0 SUPPLEMENTAL DATA--Continued

10.4 Daily and Monthly Rainfall Values for Five Recording Rainfall Gages, 1980 and 1981 Water Years--Continued

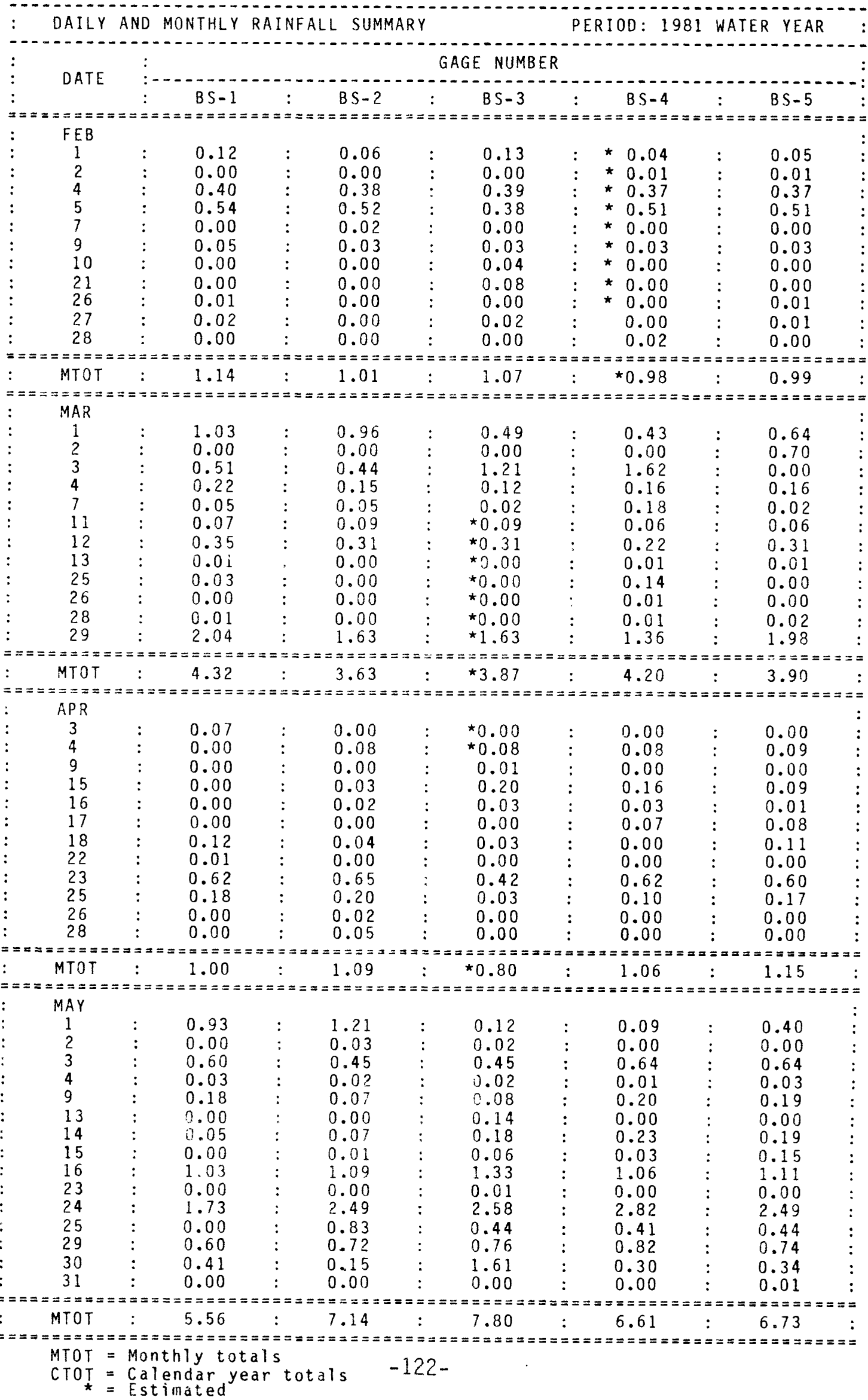


10.0 SUPPLEMENTAL DATA--Cont inued

10.4 Daily and Monthly Rainfall Values for Five Recording Rainfall Gages, 1980 and 1981 Water Years --Cont inued

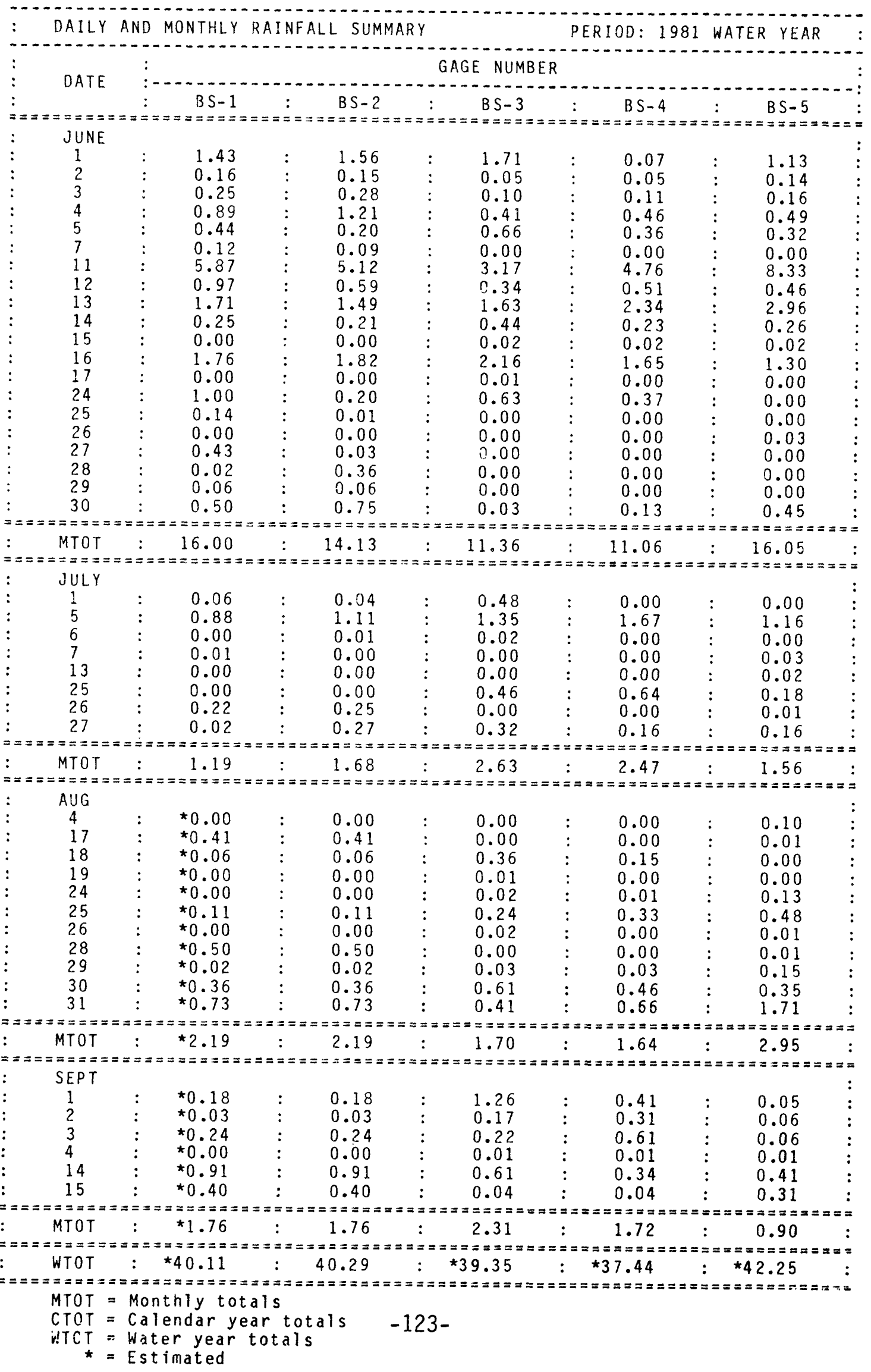


10.0 SUPPLEMENTAL DATA

10.5 Incremental Values of Rainfall and Runoff for Selected Storms, 1980 and 1981 water years

STORM OF MARCH 27, 1980

\begin{tabular}{|c|c|c|c|c|}
\hline $\begin{array}{l}\text { Date and } \\
\text { time }\end{array}$ & Gage number & $\begin{array}{l}\text { Accumulated } \\
\text { weighted } \\
\text { precipitation } \\
\text { (inches) }\end{array}$ & $\begin{array}{l}\text { Discharge } \\
\text { (cubic } \\
\text { feet per } \\
\text { second) }\end{array}$ & $\begin{array}{c}\text { Accumulated } \\
\text { runoff } \\
\text { (inches) }\end{array}$ \\
\hline
\end{tabular}

1980 water year

Station 08159165, Big Sandy Creek near McDade, Texas

$\underline{3-B S} \quad \underline{4-B S}$

March 27

0000

$0.0 \quad 0.0$

0215

$.01 \quad .01$

0300

$.05 \quad .09$

0615

$.07 \quad .13$

0745

$.42 \quad .28$

0800

$.71 \quad .38$

0815

$.92 \quad .63$

0845

1.22

.82

$1.46 \quad 1.04$

0900

0915

1 ก30

1115

1.69

1.17

$1.84 \quad 1.32$

$1.96 \quad 1.49$

1200

2.72

1.75

2.92

2.09

2.98

2.26

1330

3.38

2.30

1415

1545

1630

1730

3.55

2.81

3.55

2.84

3.55

2.84

3.55

2.84

1830

1915

2030

2130

2230

2400

March 28

0000

0130

3.55

2.84

3.55

2.84

3.55

2.84

3.55

2.84

3.56

2.87

3.56

2.87

3.56

2.87

3.56

2.87

0300

3.56

2.87

0430

3.56

2.87

0700

3.56

2.87

1100

3.56

2.87

0.0

.01

.07

.10

.36

.57

.80

1.05

1.28

1.47

1.62

1.76

2. 30

2.56

2.67

2.92

3.23

3.24

3.24

3.24

3.24

3.24

3.24

3.24

3.26

3.26

3.26

3.26

3.26

3.26

3.26

3.26
2.2

2.2

2.2

2.2

2.7

2.6

2.7

2.7

3.3

3.8

4.3

15.0

31.0

57.0

105.0

152.0

229.0

370.0

483.0

557.0

681.0

812.0

968.0

989.0

952.0

827.0

827.0

672.0

496. C

343.0

178.0

102.0
0.0001

.0002

.0004

.0006

.0007

.0007

.0008

.0008

.0008

.0009

.0010

.0016

.0025

.0045

.0077

.0115

.0218

.0385

.0554

.0785

.1023

.1349

.1785

.2181

.2657

.3030

.3030

.3557

.3855

.4130

.4362

.4525 
10.0 SUPPLEMENTAL DATA--Continued

10.5 Incremental Values of Rainfall and Runoff for Selected Storms, 1980 and 1981 water years--Continued

STORM OF MARCH 27, 1980--Continued

\begin{tabular}{|c|c|c|c|c|}
\hline $\begin{array}{c}\text { Date and } \\
\text { time }\end{array}$ & Gage number & $\begin{array}{l}\text { Accumulated } \\
\text { weighted } \\
\text { precipitation } \\
\text { (inches) }\end{array}$ & $\begin{array}{l}\text { Discharge } \\
\text { (cubic } \\
\text { feet per } \\
\text { second) }\end{array}$ & $\begin{array}{c}\text { Accumulated } \\
\text { runoff } \\
\text { (inches) }\end{array}$ \\
\hline
\end{tabular}

1980 water year

Station 08159165, Big Sandy Creek near McDade, Texas--Continued

3-BS 4-BS

March 28--Continued

$\begin{array}{llllll}1500 & 3.56 & 2.87 & 3.26 & 64.0 & 0.4628 \\ 1900 & 3.56 & 2.87 & 3.26 & 44.0 & .4707 \\ 2400 & 3.56 & 2.87 & 3.26 & 31.0 & .4763 \\ \text { March } 29 & & & & & \\ 0000 & 3.56 & 2.87 & 3.26 & 31.0 & .4763 \\ 0800 & 3.56 & 2.87 & 3.26 & 21.0 & .4855 \\ 1600 & 3.56 & 2.87 & 3.26 & 17.0 & .4909 \\ 2400 & 3.56 & 2.87 & 3.26 & 13.0 & .4930\end{array}$


10.0 SUPPLEMENTAL DATA--Continued

10.5 Incremental Values of Rainfall and Runoff for Selected Storms,

STORM OF MARCH 27, 1980--Continued

\begin{tabular}{|c|c|c|c|c|}
\hline $\begin{array}{c}\text { Date and } \\
\text { time }\end{array}$ & Gage number & $\begin{array}{l}\text { Accumulated } \\
\text { weighted } \\
\text { precipitation } \\
\text { (inches) }\end{array}$ & $\begin{array}{l}\text { Discharge } \\
\text { (cubic } \\
\text { feet per } \\
\text { second) }\end{array}$ & $\begin{array}{c}\text { Accumulated } \\
\text { runoff } \\
\text { (inches) }\end{array}$ \\
\hline
\end{tabular}

1980 water year

Station 08159170, Big Sandy Creek near Elgin, Texas

$\underline{3-B S} \quad \underline{4-B S} \quad \underline{5-B S}$

March 27

$\begin{array}{lcccccc}0000 & 0.0 & 0.0 & 0.0 & 0.0 & 1.2 & 0.0000 \\ 0130 & .0 & .0 & .01 & .00 & 1.2 & .0001 \\ 0230 & .03 & .05 & .23 & .09 & 1.3 & .0001 \\ 0330 & .06 & .12 & .30 & .15 & 1.3 & .0001 \\ 0615 & .07 & .13 & .30 & .15 & 1.4 & .0002 \\ 0700 & .19 & .17 & .32 & .22 & 1.4 & .0002 \\ 0745 & .42 & .28 & .49 & .38 & 1.8 & .0003 \\ 0800 & .71 & .38 & .90 & .63 & 2.1 & .0003 \\ 0815 & .92 & .63 & 1.19 & .88 & 2.3 & .0003 \\ 0830 & 1.22 & .82 & 1.35 & 1.10 & 2.9 & .0003 \\ 0845 & 1.46 & 1.04 & 1.62 & 1.34 & 3.0 & .0003 \\ 0915 & 1.84 & 1.32 & 1.85 & 1.64 & 3.5 & .0004 \\ 1000 & 1.85 & 1.41 & 1.87 & 1.59 & 7.3 & .0005 \\ 1045 & 1.99 & 1.65 & 1.95 & 1.85 & 11.0 & .0007 \\ 1115 & 2.72 & 1.75 & 2.09 & 2.19 & 13.0 & .0008 \\ 1145 & 2.84 & 2.04 & 2.21 & 2.37 & 15.0 & .0011 \\ 1230 & 2.95 & 2.26 & 2.31 & 2.52 & 21.0 & .0014 \\ 1315 & 3.13 & 2.26 & 2.31 & 2.59 & 51.0 & .0022 \\ 1345 & 3.51 & 2.47 & 2.48 & 2.85 & 84.0 & .0035 \\ 1430 & 3.55 & 2.84 & 2.60 & 3.03 & 135.0 & .0088 \\ 1700 & 3.55 & 2.84 & 2.60 & 3.03 & 278.0 & .0240 \\ 1900 & 3.55 & 2.84 & 2.60 & 3.03 & 415.0 & .0442 \\ 2100 & 3.55 & 2.84 & 2.60 & 3.03 & 652.0 & .0679 \\ 2200 & 3.56 & 2.84 & 2.61 & 3.04 & 828.0 & .0880 \\ 2300 & 3.56 & 2.87 & 2.61 & 3.05 & 1010.0 & .1126 \\ 2400 & 3.56 & 2.87 & 2.61 & 3.05 & 1160.0 & .1372 \\ \text { March } 28 & & & & & & \\ 0000 & 3.56 & 2.87 & 2.61 & 3.05 & 1160.0 & .1372 \\ 0130 & 3.56 & 2.87 & 2.61 & 3.05 & 1320.0 & .1799 \\ 0200 & 3.56 & 2.87 & 2.61 & 3.05 & 1340.0 & .2043 \\ 0300 & 3.56 & 2.87 & 2.61 & 3.05 & 1330.0 & .2527 \\ 0500 & 3.56 & 2.87 & 2.61 & 3.05 & 1140.0 & .3081 \\ 0700 & 3.56 & 2.87 & 2.61 & 3.05 & 843.0 & .3490\end{array}$


10.0 SUPPLEMENTAL DATA--Continued

10.5 Incremental Values of Rainfall and Runoff for Selected Storms, 1980 and 1981 water years--Continued

STORM OF MARCH 27, 1980--Continued

\begin{tabular}{|c|c|c|c|c|}
\hline $\begin{array}{c}\text { Date and } \\
\text { time }\end{array}$ & Gage number & $\begin{array}{l}\text { Accumulated } \\
\text { weighted } \\
\text { precipitation } \\
\text { (inches) }\end{array}$ & $\begin{array}{l}\text { Discharge } \\
\text { (cubic } \\
\text { feet per } \\
\text { second) }\end{array}$ & $\begin{array}{c}\text { Accumulated } \\
\text { runoff } \\
\text { (inches) }\end{array}$ \\
\hline
\end{tabular}

1980 water year

Station 08159170, Big Sandy Creek near Elgin, Texas--Continued

3-BS 4-BS 5-BS

March 28--Continued

$\begin{array}{lllllll}0900 & 3.56 & 2.87 & 2.61 & 3.05 & 556.0 & 0.3761 \\ 1100 & 3.56 & 2.87 & 2.61 & 3.05 & 278.0 & .3929 \\ 1400 & 3.56 & 2.87 & 2.61 & 3.05 & 117.0 & .4015 \\ 1700 & 3.56 & 2.87 & 2.61 & 3.05 & 72.0 & .4071 \\ 2030 & 3.56 & 2.87 & 2.61 & 3.05 & 48.0 & .4112 \\ 2400 & 3.56 & 2.87 & 2.61 & 3.05 & 36.0 & .4136 \\ \text { March 29 } & & & & & & \\ 0000 & 3.56 & 2.87 & 2.61 & 3.05 & 36.0 & .4136 \\ 0400 & 3.56 & 2.87 & 2.61 & 3.05 & 28.0 & .4186 \\ 1200 & 3.56 & 2.87 & 2.61 & 3.05 & 20.0 & .4234 \\ 2400 & 3.56 & 2.87 & 2.61 & 3.05 & 14.0 & .4255\end{array}$


10.0 SUPPLEMENTAL DATA--Continued

10.5 Incremental Values of Rainfall and Runoff for Selected Storms, 1980 and 1981 water years--Continued

STORM OF MAY $13-14,1980$

\begin{tabular}{|c|c|c|c|c|}
\hline $\begin{array}{l}\text { Date and } \\
\text { time }\end{array}$ & Gane number & $\begin{array}{l}\text { Accumulated } \\
\text { weighted } \\
\text { precipitation } \\
\text { (inches) }\end{array}$ & $\begin{array}{l}\text { Discharge } \\
\text { (cubic } \\
\text { feet per } \\
\text { second) }\end{array}$ & $\begin{array}{c}\text { Accumulated } \\
\text { runoff } \\
\text { (inches) }\end{array}$ \\
\hline
\end{tabular}

Station 08159165, Biq̣ Sandy Creek near McDade, Texas

4-BS

May 13

0000

0300

0.0

.01

.02

.05

1415

1430

1445

1500

1545

1615

1700

1800

1900

2000

2100

2200

2400

May 14

0000

0130

0230

0400

0600

0800

1000

1200

1400

1700

2030

2400

May 15

0000

0800

.27

.76

.98

1.13

1.34

1.51

1.78

1.89

2.13

2.40

2.50

2.51

2.51

2.51

2.51

2.51

2.51

2.51

2.51

2.52

2.52

2.52

2.58

2.58

2.58

2.58
0.0

.01

.02

.05

.27

.76

.98

1.13

1.34

1.51

1.78

1.89

2.13

2.40

2. 50

2.51

2. 51

2.51

2.51

2.51

2. 51

2.51

2.51

2.52

2.52

2.52

2.58

2.58

2.58

2.58
70.0

60.0

27.0

13.0

12.0

15.0

18.0

26.0

59.0

155.0

262.0

400.0

592.0

685.0

722.0

874.0

874.0

969.0

984.0

937.0

823.0

706.0

578.0

421.0

266.0

149.0

94.0

62.0

62.0

37.0
0.0042

.0138

.0199

.0216

.0217

.0219

.0222

.0229

.0243

.0298

.0403

.0563

.0800

.1074

.1508

.1989

.1989

.2605

.3098

.3754

.4413

.4979

.5442

.5779

.6045

.6239

.6371

.6464

.6464

.6580 
10.0 SUPPLEMENTAL DATA--Continued

10.5 Incremental Values of Rainfall and Runoff for Selected Storms, 1980 and 1981 water years--Continued

STORM OF MAY 13-14, 1980--Continued

\begin{tabular}{|c|c|c|c|c|}
\hline $\begin{array}{l}\text { Date and } \\
\text { time }\end{array}$ & Gage number & $\begin{array}{l}\text { Accumulated } \\
\text { weighted } \\
\text { precipitation } \\
\text { (inches) }\end{array}$ & $\begin{array}{l}\text { Discharge } \\
\text { (cubic } \\
\text { feet per } \\
\text { second) }\end{array}$ & $\begin{array}{c}\text { Accumulated } \\
\text { runoff } \\
\text { (inches) }\end{array}$ \\
\hline
\end{tabular}

1980 water year

Station 08159170, Big Sandy Creek near Elgin, Texas

$\underline{4-B S} \quad \underline{5-B S}$

May 13

0000

0300

1300

1315

1330

1415

1430

1445

1500

1600

1700

1730

1745

1800

1900

2000

2100

2200

2300

2400

May 14

0000

0200

0400

0600

0630

0700

0900

1100

1300

1500

1700

1830

$0.0 \quad 0.0$

$.01 \quad .0$

$.04 \quad .04$

$.04 \quad .41$

$.04 \quad 1.12$

$.05 \quad 1.33$

$.27 \quad 1.39$

$.76 \quad 1.42$

$.98 \quad 1.44$

1.27

1.51

1.63

1.71

1.78

1.89

2.13

2.40

2.50

2.51

2.51

2.51

2.51

2.51

2.51

2.51

2.51

2.51

2.51

2.52

2.52

2.52

2.58
1.71

1.95

2.17

2.51

2.72

2.81

3.11

3.17

3.17

3.17

3.17

3.17

3.18

3.18

3.18

3.18

3.18

3.18

3.18

3.19

3.19

3.19

3.30
0.0

.01

.04

.17

.43

.51

.67

1.00

1.15

1.43

1.67

1.82

2.00

2.12

2.22

2.48

2.68

2.74

2.75

2.75

2.75

2.75

2.75

2.75

2.75

2.75

2.75

2.75

2.76

2.76

2.76

2.84
44.0

54.0

36.0

35.0

36.0

35.0

41.0

40.0

40.0

139.0

201.0

235.0

251.0

267.0

347.0

448.0

553.0

686.0

904.0

1140.0

1140.0

1460.0

1610.0

1690.0

1720.0

1690.0

1520.0

1250.0

1010.0

819.0

604.0

421.0
0.0016

.0101

.0146

.0148

.0153

.0157

.0159

.0162

.0168

.0202

.0238

.0260

.0275

.0315

.0400

.0508

.0643

.0809

.1029

.1306

.1306

.2154

.2936

.3449

.3658

.4171

.4909

.5516

.6007

.6405

.6661

.6815 
10.0 SUPPLEMENTAL DATA--Continued

10.5 Incremental Values of Rainfall and Runoff for Selected Storms, 1980 and 1981 water years--Con tinuer

STORM OF MAY 13-14, 1980--Continued

\begin{tabular}{|c|c|c|c|c|}
\hline $\begin{array}{c}\text { Date and } \\
\text { time }\end{array}$ & Gage number & $\begin{array}{l}\text { Accumulated } \\
\text { weighted } \\
\text { precipitation } \\
\text { (inches) }\end{array}$ & $\begin{array}{l}\text { Discharge } \\
\text { (cubic } \\
\text { feet per } \\
\text { second) }\end{array}$ & $\begin{array}{c}\text { Accumulated } \\
\text { runoff } \\
\text { (inches) }\end{array}$ \\
\hline
\end{tabular}

1980 water year

Station 08159170, Bia Sandy Creek near Elgin, Texas

4-BS 5-BS

May 14--Continued

2000

2200

2400

May 15

0000

$2.58 \quad 3.32$

$2.58 \quad 3.32$

2.85

298.0

195.0

0.6941

$2.58 \quad 3.32$

2.85

139.0

.7036

.7095

0300

$2.58 \quad 3.32$

2. 85

2.58

3.32

$2.58 \quad 3.32$

2.85

139.0

.7095

2.85

93.0

51.0

.7245

.7375 
10.0 SUPPLEMENTAL DATA--Continued

10.5 Incremental Values of Rainfall and Runoff for Selected Storms, 1980 and 1981 water years--Cont inued

STORM OF MAY 13-14, 1980--Continued

\begin{tabular}{cccc}
$\begin{array}{c}\text { Date and } \\
\text { time }\end{array}$ Gage number & $\begin{array}{c}\text { Accumulated } \\
\text { weighted } \\
\text { precipitation } \\
\text { (inches) }\end{array}$ & $\begin{array}{c}\text { Discharge } \\
\text { (cubic } \\
\text { feet per } \\
\text { second) }\end{array}$ & $\begin{array}{c}\text { Accumulated } \\
\text { runoff } \\
\text { (inches) }\end{array}$ \\
\hline
\end{tabular}

1980 water year

Station 08159180, Big Sandy Creek near McDade, Texas

$2-B S$

May 13

$\begin{array}{llrrl}0000 & 0.0 & 0.0 & 0.0 & 0.0 \\ 0415 & .01 & .01 & .0 & .0 \\ 1400 & .03 & .03 & .5 & .0073 \\ 1415 & .09 & .09 & 1.0 & .0080 \\ 1430 & .59 & .59 & 2.0 & .0095 \\ 1445 & 1.44 & 1.44 & 4.0 & .0124 \\ 1500 & 1.60 & 1.60 & 7.8 & .0210 \\ 1530 & 1.71 & 1.71 & 9.9 & .0318 \\ 1545 & 1.84 & 1.84 & 27.0 & .0516 \\ 1600 & 1.93 & 1.93 & 54.0 & .1108 \\ 1630 & 2.02 & 2.02 & 45.0 & .1766 \\ 1700 & 2.16 & 2.16 & 32.0 & .2350 \\ 1745 & 2.40 & 2.40 & 23.0 & .2855 \\ 1830 & 2.57 & 2.57 & 26.0 & .3425 \\ 1915 & 2.81 & 2.81 & 31.0 & .4105 \\ 2000 & 2.84 & 2.84 & 28.0 & .4616 \\ 2030 & 3.06 & 3.06 & 23.0 & .4952 \\ 2100 & 3.22 & 3.22 & 21.0 & .5259 \\ 2130 & 3.30 & 3.30 & 20.0 & .5625 \\ 2215 & 3.32 & 3.32 & 27.0 & .6217 \\ 2300 & 3.32 & 3.32 & 23.0 & .6805 \\ 2400 & 3.32 & 3.32 & 14.0 & .7112 \\ \text { May } 14 & .32 & 3.32 & 14.0 & .7112 \\ 0000 & 3.32 & 3.32 & 14.0 & .7507 \\ 0100 & 3.32 & 3.32 & 5.0 & .7990 \\ 0400 & 3.32 & 3.32 & 3.0 & .8282 \\ 1200 & 3.33 & 3.33 & 1.0 & \end{array}$


10.0 SUPPLEMENTAL DATA--Continued

10.5 Incremental Values of Rainfall and Runoff for Selected Storms, 1980 and 1981 water years--Continued

STORM OF MAY 13-14, 1980--Continued

\begin{tabular}{|c|c|c|c|c|}
\hline $\begin{array}{c}\text { Date and } \\
\text { time }\end{array}$ & Gage number & $\begin{array}{l}\text { Accumulated } \\
\text { weighted } \\
\text { precipitation } \\
\text { (inches) }\end{array}$ & $\begin{array}{l}\text { Discharge } \\
\text { (cubic } \\
\text { feet per } \\
\text { second) }\end{array}$ & $\begin{array}{c}\text { Accumulated } \\
\text { runoff } \\
\text { (inches) }\end{array}$ \\
\hline
\end{tabular}

1980 water year

Station 08159185, Dogwood Creek at Hwy. 95 near McDade, Texas

$1-B S \quad 2-B S$

May 13

0000

0415

0.0

0.0

0.0

.00

.01

1415

1430

1445

1500

1530

1600

1630

1700

1800

1845

1900

1915

1930

2000

2100

2145

2215

2400

May 14

0000

0200

0400

0600

0730

0800

0830

1000

1030

$.0 \quad .01$

$.02 \quad .03$

$.16 \quad .59$

$.69 \quad 1.44$

$1.18 \quad 1.60$

$1.28 \quad 1.71$

.04

.29

.91

1.31

1.41

1.49

1.93

1.62

1.69

1.55

2.02

1.84

2.02

2.46

2.15

2.65

2.29

2.75

2.36

2.43

2.30

2.81

2.32

2.81

2.34

2.84

2.63

3.22

2.78

3.32

$2.80 \quad 3.32$

2.45

2.47

2.49

2.81

2.94

2.96

$3.20 \quad 3.32$

3.24

3.20

3.32

3.20

3.32

3.20

3.32

3.20

3.33

3.20

3.33

3.33

3.33

3.60

3.33

3.60

3.33

1100

3.73

3.33

4.00

3.33

3.24

3.24

3.24

3.24

3.24

3.33

3.52

3.52

3.61

4.13

3.33

3.80

3.89

1.0

0.0007

.0028

.0044

.0044

1.0

2.0

3.0

4.0

10.0

15.0

39.0

94.0

118.0

128.0

130.0

.0046

.0048

.0053

.0068

.0091

.0151

.0369

.0687

.0884

.0984

119.0

.1076

127.0

.1222

.1474

109.0

.1763

107.0

.1969

107.0

.2339

97.0

.2750

1130

97.0

.2750

75.0

43.0

.3362

26.0

20.0

18.0

16.0

10.0

10.0

10.0

.3627

.3767

.3829

.3856

.3906

.3936

.3952

.3967

11.0

.3984 
10.0 SUPPLEMENTAL DATA--Continued

10.5 Incremental Values of Rainfall and Runoff for Selected Storms, 1980 and 1981 water years--Continued

STORM OF MAY 13-14, 1980--Continued

\begin{tabular}{|c|c|c|c|c|}
\hline $\begin{array}{c}\text { Date and } \\
\text { time }\end{array}$ & Gage number & $\begin{array}{l}\text { Accumulated } \\
\text { weighted } \\
\text { precipitation } \\
\text { (inches) }\end{array}$ & $\begin{array}{l}\text { Discharge } \\
\text { (cubic } \\
\text { feet per } \\
\text { second) }\end{array}$ & $\begin{array}{l}\text { Accumulated } \\
\text { runoff } \\
\text { (inches) }\end{array}$ \\
\hline
\end{tabular}

1980 water year

Station 08159185, Dogwood Creek at Hwy. 95 near McDade, Texas--Continued

$$
\text { 1-BS 2-BS }
$$

May 14--Continued

$\begin{array}{llllll}1200 & 4.40 & 3.33 & 4.08 & 11.0 & 0.4010 \\ 1300 & 4.40 & 3.33 & 4.08 & 12.0 & .4037 \\ 1330 & 4.81 & 3.33 & 4.37 & 12.0 & .4102 \\ 1630 & 4.81 & 3.34 & 4.37 & 13.0 & .4172 \\ 1700 & 4.99 & 3.54 & 4.55 & 13.0 & .4252 \\ 2030 & 5.13 & 3.75 & 4.72 & 14.0 & .4349 \\ 2130 & 5.13 & 3.75 & 4.72 & 19.0 & .4408 \\ 2230 & 5.13 & 3.75 & 4.72 & 21.0 & .4489 \\ 2400 & 5.13 & 3.75 & 4.72 & 18.0 & .4572 \\ \text { May } 15 & & & & & \\ 0000 & 5.13 & 3.75 & 4.72 & 18.0 & .4572 \\ 0300 & 5.13 & 3.75 & 4.72 & 14.0 & .4743 \\ 0600 & 5.13 & 3.75 & 4.72 & 10.0 & .4881 \\ 1200 & 5.13 & 3.75 & 4.72 & 5.0 & .4974 \\ 1800 & 5.13 & 3.75 & 4.72 & 2.0 & .5011 \\ 2400 & 5.13 & 3.75 & 4.72 & 1.0 & .5020\end{array}$


10.0 SUPPLEMENTAL DATA--Continued

10.5 Incremental Values of Rainfall and Runoff for Selected Storms, 1980 and 1981 water years--Continued

STORM OF JUNE $11-14,1981$

\begin{tabular}{|c|c|c|c|c|}
\hline $\begin{array}{c}\text { Date and } \\
\text { time }\end{array}$ & Gage number & $\begin{array}{l}\text { Accumulated } \\
\text { weighted } \\
\text { precipitation } \\
\text { (inches) }\end{array}$ & $\begin{array}{l}\text { Discharge } \\
\text { (cubic } \\
\text { feet per } \\
\text { second) }\end{array}$ & $\begin{array}{c}\text { Accumulated } \\
\text { runoff } \\
\text { (inches) }\end{array}$ \\
\hline
\end{tabular}

1981 water year

Station 08159165, Big Sandy Creek near McDade, Texas

3-BS 4-BS

June 11

0000

0130

0315

0330

0345

0400

0415

0430

0455

0500

0530

0600

0630

0645

0700

0800

0900

1045

1200

1300

1400

1530

1700

1830

2000

2200

2400

June 12

0000

0230

0600

0800

1200

$\begin{array}{ccc}0.0 & 0.0 & 0.0 \\ .01 & .0 & .01 \\ .10 & .01 & .06 \\ .10 & .17 & .13 \\ .18 & .73 & .42 \\ .46 & 1.30 & .82 \\ .83 & 1.71 & 1.21 \\ 1.24 & 2.45 & 1.76 \\ 1.72 & 3.38 & 2.43 \\ 2.13 & 4.01 & 2.94 \\ 2.33 & 4.20 & 3.13 \\ 2.53 & 4.33 & 3.30 \\ 2.58 & 4.40 & 3.36 \\ 2.61 & 4.43 & 3.39 \\ 2.63 & 4.46 & 3.42 \\ 2.69 & 4.52 & 3.48 \\ 2.81 & 4.56 & 3.56 \\ 2.83 & 4.58 & 3.58 \\ 2.83 & 4.58 & 3.58 \\ 2.97 & 4.58 & 3.66 \\ 3.06 & 4.58 & 3.71 \\ 3.12 & 4.60 & 3.76 \\ 3.14 & 4.61 & 3.77 \\ 3.14 & 4.61 & 3.77 \\ 3.17 & 4.76 & 3.85 \\ 3.17 & 4.76 & 3.85 \\ 3.17 & 4.76 & 3.85\end{array}$

0

06

.13

.82

1.21

2.43

2.94

3.13

3.36

3.39

3.42

3.56

3.58

3.66

3.71

3.76

3.77

3.77

3.85

3.85

3.85

3.88

4.08

4.17
0.9

8.8

43.0

117.0

246.0

420.0

659.0

974.0

2420.0

3790.0

4370.0

4410.0

4370.0

3860.0

3680.0

3060.0

2440.0

2100.0

1820.0

1420.0

1060.0

780.0

599.0

495.0

407.0

407.0

299. 0

180.0

185.0

143.0
.0000

.0001

.0002

.0003

.0007

.0019

.0043

.0085

.0151

.0298

.0782

.1541

.2197

.2639

.3732

.5278

.7304

.9142

1.0241

1.1082

1.1993

1.2846

1.3482

1.3951

1.4370

1.4767

1.5032

1.5032

1.5493

1.5691

1.5913

1.6199 
10.0 SUPPLEMENTAL DATA--Continued

10.5 Incremental Values of Rainfall and Runoff for Selected Storms, 1980 and 1981 water years--Continued

STORM OF JUNE 11-14, 1981--Continued

\begin{tabular}{|c|c|c|c|c|}
\hline $\begin{array}{l}\text { Date and } \\
\text { time }\end{array}$ & Gage number & $\begin{array}{l}\text { Accumulated } \\
\text { weighted } \\
\text { precipitation } \\
\text { (inches) }\end{array}$ & $\begin{array}{l}\text { Discharge } \\
\text { (cubic } \\
\text { feet per } \\
\text { second) }\end{array}$ & $\begin{array}{c}\text { Accumulated } \\
\text { runoff } \\
\text { (inches) }\end{array}$ \\
\hline
\end{tabular}

1981 water year

Station 08159165, Big Sandy Creek near McDade, Texas--Continued

3-BS 4-BS

June 12--Continued

$\begin{array}{lll}1800 & 3.51 & 5.27\end{array}$

$\begin{array}{lll}2400 & 3.51 & 5.27\end{array}$

4.27

4.27

102.0

1.6444

June 13

0000

0300

3.51

5.27

4.27

4.27

4.27

4.35

4.40

1000

3.52

5.27

3.61

5.34

1130

3.64

5.41

1345

3.79

5.71

1430

3.88

5.80

1500

3.96

5.98

1530

4.13

6.60

4.36

6.86

1600

4.50

7.14

1630

4.55

7.19

4.55

7.26

1800

4.65

7.33

1830

4.74

7.33

4.99

7.39

$5.05 \quad 7.60$

4.62

4.71

4.83

5.19

5.43

5.64

5.69

5.72

5.80

5.85

6.02

6.15

$5.10 \quad 7.60$

6.17

6.19

6.20

77.0

1.6560

2100

$5.13 \quad 7.60$

2400

June 14

0000

5.14

7.61

$5.14 \quad 7.61$

0400

5.20

7.65

6.20

6.25

5.20

7.66

1100

5.23

7.67

6.26

6.28

$5.23 \quad 7.80$

6.34

$\begin{array}{ll}5.25 & 7.82\end{array}$

6.36

$\begin{array}{ll}5.57 & 7.83\end{array}$

6.54

$5.58 \quad 7.84$

6.55

77.0

1.6560

1.6682

1.6732

1.6747

1.6764

1.6803

1.6877

1.6939

1.7008

1.7110

1.7259

1.7491

1.7966

1.8551

1.8946

1.9431

2.0176

2.1090

2. 1967

2.2892

1700

1660.0

1460.0

1320.0

2.2892

1320.0

2.5326

2. 6321

2.6688

2.6929

2.7056

2.7284

2.7475 
10.0 SUPPLEMENTAL DATA--Continued

10.5 Incremental Values of Rainfall and Runoff for Selected Storms, 1980 and 1981 Water years--Cont inued

STORM OF JUNE 11-14, 1981--Continued

\begin{tabular}{cccc}
$\begin{array}{c}\text { Date and } \\
\text { time }\end{array} \quad$ Gage number & $\begin{array}{c}\text { Accumulated } \\
\text { weighted } \\
\text { precipitation } \\
\text { (inches) }\end{array}$ & $\begin{array}{c}\text { Discharge } \\
\text { (cubic } \\
\text { feet per } \\
\text { second) }\end{array}$ & $\begin{array}{c}\text { Accumulated } \\
\text { runoff } \\
\text { (inches) }\end{array}$ \\
\hline 1981 water year &
\end{tabular}

Station 08159165, Big Sandy Creek near McDade, Texas--Continued

$$
\text { 3-BS 4-BS }
$$

June 15

0000

0400

$5.58 \quad 7.84$

6.55

106.0

6.55

73.0

6.55

$5.58 \quad 7.84$

6.57

47.0

$5.60 \quad 7.85$

6.57

27.0

16.0

2.7475

2.7649

2.7752

$5.60 \quad 7.86$

6.57

2.7833

2.7862 
10.0 SUPPLEMENTAL DATA--Continued

10.5 Incremental Values of Rainfall and Runoff for Selected Storms, 1980 and 1981 water years--Continued

STORM OF JUNE 11-14, 1981--Continued

\begin{tabular}{|c|c|c|c|c|}
\hline $\begin{array}{c}\text { Date and } \\
\text { time }\end{array}$ & Gage number & $\begin{array}{l}\text { Accumulated } \\
\text { weighted } \\
\text { precipitation } \\
\text { (inches) }\end{array}$ & $\begin{array}{l}\text { Discharge } \\
\text { (cubic } \\
\text { feet per } \\
\text { second) }\end{array}$ & $\begin{array}{c}\text { Accumulated } \\
\text { run off } \\
\text { (inches) }\end{array}$ \\
\hline
\end{tabular}

1981 water year

Station 08159170, Big Sandy Creek near Elgin, Texas

3-BS 4-BS 5-BS

June 11

0000

0130

0230

$\begin{array}{lll}0.0 & 0.0 & 0.0\end{array}$

0245

$.01 \quad .0$

$\begin{array}{lll}.06 & .0 & .05\end{array}$

.0

$\begin{array}{lll}.08 & .01 & .17\end{array}$

$\begin{array}{lll}.10 & .01 & .65\end{array}$

0300

.10

.10

.01

1.22

0330

.18

.17

1.58

0345

.46

.73

2.27

0400

.83

1.30

3.62

0415

1.24

1.71

4.78

1.72

2.45

5.31

0445

2.13

3.38

6.03

4.01

6.86

0515

2.27

4.12

7.20

4.33

7.64

0700

2.63

4.46

7.83

0745

2.67

4.51

7.86

0830

2.74

4.54

7.89

0900

2.81

4.56

7.91

2.82

4.58

7.93

1030

2.83

4.58

7.94

4.58

7.94

1200

2.83

4.58

7.94

3.04

4.58

8.06

1530

3.12

4.60

8.30

1730

3.14

4.61

8.32

1900

3.14

4.66

8.32

3.17

4.76

8.33

2400

3.17

4.76

8.33

0.0

.00

.03

.08

.21

.36

.51

.93

1.60

2.19

2.76

3.47

4.07

4.25

4.54

4.68

4.72

4.76

4.80

4.82

4.82

4.82

4.82

4.93

5.03

5.05

5.06

5.12

5.12

5.12

5.12

5.16
1.2

1.2

1.2

1.2

1.2

1.2

1.2

2.0

2.2

2.1

4.8

9.9

54.0

180.0

574.0

886.0

1200.0

2470.0

3650.0

5060.0

5640.0

5760.0

5590.0

4860.0

3820.0

3010.0

2360.0

1680.0

1060.0

1060.0

767.0

524.0
0.0000

.0001

.0001

.0001

.0001

.0001

.0001

.0001

.0001

.0001

.0002

.0002

.0006

.0027

.0149

.0338

.0556

.0931

.1485

.2407

.3263

.4313

.6179

.8245

.9985

1.1264

1.2267

1.3287

1.3867

1.3867

1.4665

1.4983 
10.0 SUPPLEMENTAL DATA--Continued

10.5 Incremental Values of Rainfall and Runoff for Selected Storms,
1980 and 1981 Water years--Continued

STORM OF JUNE 11-14, 1981--Continued

\begin{tabular}{|c|c|c|c|c|}
\hline $\begin{array}{c}\text { Date and } \\
\text { time }\end{array}$ & Gage number & $\begin{array}{l}\text { Accumulated } \\
\text { weighted } \\
\text { precipitation } \\
\text { (inches) }\end{array}$ & $\begin{array}{l}\text { Discharge } \\
\text { (cubic } \\
\text { feet per } \\
\text { second) }\end{array}$ & $\begin{array}{c}\text { Accumulated } \\
\text { runoff } \\
\text { (inches) }\end{array}$ \\
\hline
\end{tabular}

1981 water year

Station 08159170, Big Sandy Creek near Elgiin, Texas--Continued

$$
\text { 3-BS 4-BS 5-BS }
$$

June 12--Continued

$\begin{array}{lllllrl}0800 & 3.32 & 5.08 & 8.51 & 5.34 & 428.0 & 1.5269 \\ 1200 & 3.42 & 5.17 & 8.66 & 5.45 & 348.0 & 1.5692 \\ 1800 & 3.51 & 5.27 & 8.79 & 5.55 & 218.0 & 1.6009 \\ 2400 & 3.51 & 5.27 & 8.79 & 5.55 & 120.0 & 1.6126 \\ \text { June } 13 & & & & & & \\ 0000 & 3.51 & 5.27 & 8.79 & 5.55 & 120.0 & 1.6126 \\ 0400 & 3.51 & 5.27 & 8.84 & 5.56 & 89.0 & 1.6247 \\ 0830 & 3.52 & 5.27 & 8.85 & 5.57 & 66.0 & 1.6287 \\ 0900 & 3.57 & 5.32 & 8.88 & 5.62 & 64.0 & 1.6295 \\ 0930 & 3.62 & 5.37 & 8.95 & 5.67 & 62.0 & 1.6302 \\ 1000 & 3.64 & 5.41 & 9.04 & 5.72 & 60.0 & 1.6310 \\ 1030 & 3.69 & 5.51 & 9.32 & 5.85 & 59.0 & 1.6317 \\ 1100 & 3.74 & 5.64 & 9.57 & 5.98 & 58.0 & 1.6324 \\ 1130 & 3.79 & 5.71 & 9.82 & 6.09 & 59.0 & 1.6335 \\ 1230 & 3.86 & 5.79 & 9.90 & 6.16 & 74.0 & 1.6357 \\ 1400 & 3.88 & 5.81 & 9.95 & 6.19 & 97.0 & 1.6381 \\ 1430 & 3.96 & 5.98 & 10.27 & 6.37 & 111.0 & 1.6391 \\ 1445 & 4.03 & 6.25 & 10.49 & 6.55 & 121.0 & 1.6398 \\ 1500 & 4.13 & 6.50 & 11.05 & 6.87 & 133.0 & 1.6410 \\ 1530 & 4.36 & 6.86 & 11.37 & 7.13 & 163.0 & 1.6430 \\ 1600 & 4.50 & 7.14 & 11.57 & 7.34 & 197.0 & 1.6466 \\ 1700 & 4.55 & 7.26 & 11.61 & 7.42 & 281.0 & 1.6534 \\ 1800 & 4.65 & 7.33 & 11.62 & 7.48 & 392.0 & 1.6629 \\ 1900 & 4.99 & 7.39 & 11.70 & 7.65 & 567.0 & 1.6767 \\ 2000 & 5.09 & 7.60 & 11.74 & 7.77 & 935.0 & 1.6994 \\ 2100 & 5.10 & 7.60 & 11.74 & 7.78 & 1560.0 & 1.7373 \\ 2200 & 5.12 & 7.60 & 11.74 & 7.78 & 2050.0 & 1.7995 \\ 2330 & 5.14 & 7.61 & 11.75 & 7.80 & 2390.0 & 1.8576 \\ 2400 & 5.14 & 7.61 & 11.75 & 7.80 & 2400.0 & 1.8867 \\ \text { June } 14 & & & & & & \\ 0000 & 5.14 & 7.61 & 11.75 & 7.80 & 2400.0 & 1.8867 \\ 0100 & 5.18 & 7.65 & 11.81 & 7.84 & 2290.0 & 2.0125 \\ 0400 & 5.20 & 7.65 & 11.84 & 7.86 & 1760.0 & 2.1622 \\ & & & & & & \end{array}$


10.0 SUPPLEMENTAL DATA--Continued

10.5 Incremental Values of Rainfall and Runoff for Selected Storms, 1980 and 1981 water years--Continued

STORM OF JUNE $11-14,1981--$ Continued

\begin{tabular}{|c|c|c|c|c|}
\hline $\begin{array}{l}\text { Date and } \\
\text { time }\end{array}$ & Gage number & $\begin{array}{l}\text { Accumulated } \\
\text { weighted } \\
\text { precipitation } \\
\text { (inches) }\end{array}$ & $\begin{array}{l}\text { Discharge } \\
\text { (cubic } \\
\text { feet per } \\
\text { second) }\end{array}$ & $\begin{array}{l}\text { Accumulated } \\
\text { runoff } \\
\text { (inches) }\end{array}$ \\
\hline
\end{tabular}

1981 water year

Station 08159170, Big Sandy Creek near Elgin, Texas--Continued

$$
\text { 3-BS 4-BS 5-BS }
$$

June 14--Continued

$\begin{array}{lllllll}0800 & 5.20 & 7.66 & 11.84 & 7.86 & 1340.0 & 2.3086 \\ 1300 & 5.23 & 7.80 & 11.98 & 7.96 & 952.0 & 2.4069 \\ 1630 & 5.27 & 7.82 & 12.01 & 7.99 & 616.0 & 2.4405 \\ 1730 & 5.58 & 7.83 & 12.01 & 8.11 & 500.0 & 2.4618 \\ 2000 & 5.58 & 7.84 & 12.01 & 8.11 & 280.0 & 2.4839 \\ 2400 & 5.58 & 7.84 & 12.01 & 8.11 & 143.0 & 2.4943 \\ \text { June } 15 & & & & & & \\ 0000 & 5.58 & 7.84 & 12.01 & 8.11 & 143.0 & 2.4943 \\ 0400 & 5.58 & 7.84 & 12.01 & 8.11 & 107.0 & 2.5095 \\ 0900 & 5.58 & 7.84 & 12.01 & 8.11 & 77.0 & 2.5207 \\ 1600 & 5.60 & 7.85 & 12.03 & 8.13 & 45.0 & 2.5289 \\ 2400 & 5.60 & 7.86 & 12.03 & 8.13 & 27.0 & 2.5315\end{array}$


10.0 SUPPLEMENTAL DATA

10.6 Summary of Aquifer Tests at the City of Bastrop Well Field (Formerly Camp Swift Military Reservation Well Field) I/

\begin{tabular}{|c|c|c|c|c|c|c|c|c|c|}
\hline \multirow{2}{*}{$\begin{array}{l}\text { Date } \\
\text { of } \\
\text { test }\end{array}$} & \multirow{2}{*}{$\begin{array}{l}\text { Pumpe } \\
\text { We11 } \\
\text { num- } \\
\text { ber }\end{array}$} & \multirow[t]{2}{*}{$\frac{e d n}{0 n}$} & \multirow[t]{2}{*}{$\frac{11}{0 \mathrm{ff}}$} & \multirow{2}{*}{$\begin{array}{l}\text { Observa- } \\
\text { tion } \\
\text { wells } \\
\text { (well num- } \\
\text { ber) }\end{array}$} & \multirow{2}{*}{$\begin{array}{l}\text { Transmis- } \\
\text { sivity } \\
\text { (feet } \\
\text { squared } \\
\text { per day) }\end{array}$} & \multirow{2}{*}{$\begin{array}{l}\text { Storage } \\
\text { coeffi- } \\
\text { cient }\end{array}$} & \multicolumn{2}{|c|}{$\begin{array}{c}\text { Time since } \\
\text { pumping } \\
\text { (hours) }\end{array}$} & \multirow{2}{*}{$\begin{array}{c}\text { Specific } \\
\text { capacity } \\
\text { after } \\
\text { pumping } \\
1.5 \text { hours } \\
\text { (gallons } \\
\text { per minute } \\
\text { per foot) }\end{array}$} \\
\hline & & & & & & & Started & Stopped & \\
\hline $\begin{array}{l}\text { Nov. 8-9, } \\
1941\end{array}$ & 2 & $x$ & -- & $1-T$ & 2,900 & 0.0050 & $4-8$ & - & -- \\
\hline $\begin{array}{l}\text { Nov. 10-11, } \\
1941\end{array}$ & $2-T$ & $x$ & -- & -- & -- & -- & -- & -- & 20 \\
\hline $\begin{array}{l}\text { Nov. 14-17, } \\
1941\end{array}$ & $2-T$ & -- & $x$ & -- & 7,800 & -- & - & $0.3-4$ & - \\
\hline Do. & $2-T$ & -- & $x$ & -- & 4,900 & -- & -- & $4-16$ & - \\
\hline Do. & $2-T$ & -- & $x$ & -- & 3,700 & -- & -- & $16-58$ & -- \\
\hline$\underset{1942}{\text { Mar. }} 31$ & 4 & $x$ & -- & -- & -- & -- & -- & -- & a/ 17 \\
\hline $\begin{array}{l}\text { Apr. } \\
1942\end{array}$ & 3 & $x$ & -- & 3 & -- & -- & -- & -- & a/ 14 \\
\hline $\begin{array}{l}\text { June } 10-12 \\
1942\end{array}$ & 2 & $x$ & -- & 3 & 7,100 & .0004 & $1-3$ & - & -- \\
\hline Do. & 2 & $x$ & -- & 3 & 3,700 & .0005 & $3-54$ & -- & -- \\
\hline Do. & 2 & $x$ & -- & 4 & 6,300 & .0003 & $1-6$ & -- & -- \\
\hline Do. & 2 & $x$ & -- & 4 & 3,700 & .0004 & $6-54$ & -- & -- \\
\hline Do. & 2 & $x$ & -- & 5 & 7,800 & .0003 & $2-5$ & -- & -- \\
\hline Do. & 2 & $x$ & -- & 5 & 3,900 & .0003 & $5-54$ & - & -- \\
\hline $\begin{array}{l}\text { June } 10-13 \text {, } \\
1942\end{array}$ & 2 & $x$ & -- & 3,4 & 5,200 & - & - & -- & - \\
\hline Do. & 2 & $x$ & -- & 3,5 & 5,200 & - & - & -- & -- \\
\hline Do. & 2 & $x$ & -- & 4,5 & 5,200 & -- & -- & -- & -- \\
\hline
\end{tabular}

See footnotes at end of table. 
10.0 SUPPLEMENTAL DATA--Continued

10.6 Summary of Aquifer Tests at the City of Bastrop Well Field (Formerly Camp Swift Military Reservation Well Field) 1/--Continued

\begin{tabular}{|c|c|c|c|c|c|c|c|c|c|c|}
\hline \multirow{2}{*}{$\begin{array}{l}\text { Date } \\
\text { of } \\
\text { test }\end{array}$} & \multirow{2}{*}{$\begin{array}{l}\text { Pumpe } \\
\text { Well } \\
\text { num- } \\
\text { ber }\end{array}$} & \multirow[t]{2}{*}{$\frac{d w E}{0 n}$} & \multirow[t]{2}{*}{$\frac{11}{0 f f}$} & \multirow{2}{*}{$\begin{array}{c}\text { Observa- } \\
\text { tion } \\
\text { wells } \\
\text { (well num- } \\
\text { ber) }\end{array}$} & \multirow{2}{*}{$\begin{array}{l}\text { Transmis- } \\
\text { sivity } \\
\text { (feet } \\
\text { squared } \\
\text { per day) }\end{array}$} & \multirow{2}{*}{$\begin{array}{l}\text { Storage } \\
\text { coeffi- } \\
\text { cient }\end{array}$} & \multicolumn{3}{|c|}{$\begin{array}{c}\text { Time since } \\
\text { pumping } \\
\text { (hours) }\end{array}$} & \multirow{2}{*}{$\begin{array}{c}\text { Specific } \\
\text { capacity } \\
\text { after } \\
\text { pumping } \\
1.5 \text { hours } \\
\text { (gallons } \\
\text { per minute } \\
\text { per foot) }\end{array}$} \\
\hline & & & & & & & $\overline{\text { Star }}$ & rted S & Stopped & \\
\hline $\begin{array}{l}\text { June 14-15, } \\
1942\end{array}$ & 1 & -- & $x$ & -- & 2,300 & -- & 0.1 & -12 & -- & -- \\
\hline Do. & 5 & -- & $x$ & -- & 11,200 & -- & & -4 & -- & -- \\
\hline Do. & 5 & - & $x$ & -- & 7,500 & -- & 4 & -11 & -- & -- \\
\hline $\begin{array}{l}\text { June } 23, \\
1942\end{array}$ & 1 & $x$ & -- & -- & -- & -- & & -- & -- & 19 \\
\hline Do. & 2 & $x$ & -- & -- & -- & -- & & -- & -- & 9.5 \\
\hline Do. & 5 & $x$ & - & -- & -- & - & & -- & -- & 21 \\
\hline $\begin{array}{l}\text { July } 25-27 \text {, } \\
1942\end{array}$ & 5 & $x$ & -- & 4 & 8,700 & .0005 & & -- & -- & -- \\
\hline Do. & 5 & $x$ & -- & 4 & 6,200 & .0006 & & -- & -- & -- \\
\hline Do. & 5 & $x$ & - & 4 & 3,600 & .0010 & & -- & -- & -- \\
\hline Do. & 5 & $x$ & -- & $2-T$ & 8,000 & .0004 & & -- & -- & -- \\
\hline Do. & 5 & $x$ & -- & $2-T$ & 6,200 & .0004 & & -- & -- & -- \\
\hline Do. & 5 & $x$ & -- & $2-T$ & 11,600 & .0005 & & -- & -- & -- \\
\hline Do. & 5 & $x$ & - & $4,2-T$ & 7,400 & -- & & -- & -- & -- \\
\hline $\begin{array}{l}\text { July 27-29, } \\
1942\end{array}$ & 5 & -- & $x$ & - & 12,000 & -- & & $5-2.5$ & -- & -- \\
\hline Do. & 5 & -- & $x$ & -- & 8,200 & -- & 2.5 & -10 & -- & -- \\
\hline Do. & 5 & -- & $x$ & -- & 5,800 & -- & 10 & -41 & -- & -- \\
\hline Do. & 5 & - & $x$ & -- & 3,900 & .0006 & 41 & -48 & -- & -- \\
\hline Do. & 5 & -- & $x$ & 4 & 8,000 & .0007 & 2.5 & -16 & -- & -- \\
\hline
\end{tabular}

See footnotes at end of table. 
10. 0 SUPPLEMENTAL DATA--Continued

10.6 Summary of Aquifer Tests at the City of Bastrop Well Field (Formerly Camp Swift Military Peservation Well Field) 1/--Continued

\begin{tabular}{|c|c|c|c|c|c|c|c|c|c|c|}
\hline \multirow{2}{*}{$\begin{array}{l}\text { Date } \\
\text { of } \\
\text { test }\end{array}$} & \multicolumn{3}{|c|}{$\frac{\text { Pumped well }}{\text { Wel1 On Off }}$} & \multirow{2}{*}{$\begin{array}{l}\text { Observa- } \\
\text { tion } \\
\text { wells } \\
\text { (well num- } \\
\text { ber) }\end{array}$} & \multirow{2}{*}{$\begin{array}{l}\text { Transmis- } \\
\text { sivity } \\
\text { (feet } \\
\text { squared } \\
\text { per day) }\end{array}$} & \multirow{2}{*}{$\begin{array}{c}\text { Storage } \\
\text { coeffi- } \\
\text { cient }\end{array}$} & \multicolumn{3}{|c|}{$\begin{array}{c}\text { Time since } \\
\text { pumping } \\
\text { (hours) }\end{array}$} & \multirow{2}{*}{$\begin{array}{l}\text { Specific } \\
\text { capacity } \\
\text { after } \\
\text { pumping } \\
\text { 1.5 hours } \\
\text { (gallons } \\
\text { per minute } \\
\text { per foot) }\end{array}$} \\
\hline & $\begin{array}{l}\text { num- } \\
\text { ber }\end{array}$ & & & & & & Star & ted St & St opped & \\
\hline $\begin{array}{l}\text { July 27-29, } \\
1942\end{array}$ & 5 & -- & $x$ & 4 & 3,200 & 0.0012 & 16 & -48 & -- & -- \\
\hline Do. & 5 & -- & $x$ & $2-T$ & 7,800 & .0005 & 2 & -6 & -- & -- \\
\hline Do. & 5 & -- & $x$ & $2-T$ & 5,200 & .0005 & 6 & -12 & -- & -- \\
\hline Do. & 5 & -- & $x$ & $2-T$ & 3,200 & .0005 & 12 & -48 & - & -- \\
\hline Do. & 5 & -- & $x$ & $4,2-T$ & 7,600 & -- & - & - & -- & -- \\
\hline $\begin{array}{l}\text { July } 31 \text {, } \\
1942- \\
\text { Aug. } 1 \text {, } \\
1942\end{array}$ & 1 & -- & $x$ & -- & 3,300 & -- & & -19 & -- & -- \\
\hline $\begin{array}{l}\text { Aug. } 1 \text {, } \\
1942\end{array}$ & $2-T$ & -- & $x$ & -- & 4,900 & -- & & $8-1.5$ & $5=$ & -- \\
\hline
\end{tabular}

1/ From Guyton (1942).

âf From tests by Layne-Texas Company. 


\subsection{Source and Significance of Selected Constituents and Properties Commonly Reported in Water Analyses $1 /$}

(mg/L - milligrams per liter)

Constituent

Silica

$\left(\mathrm{SiO}_{2}\right)$

Iron

(Fe)

Calcium

(Ca)

Magnesium (Mg)

Sodium

(Na)

Source or cause

\author{
Stgnificance
}

Silicon ranks second only to oxygen in abundance in the Earth's crust. Contact of natural waters with silica-bearing rocks and soils usually results in a concentration range of about 1 to $30 \mathrm{mg} / \mathrm{L}$; but concentrations as large as $100 \mathrm{mg} / \mathrm{L}$ are common in waters in some areas.

Iron is an abundant and widespread constituent of many rocks and soils. Iron concentrations in natural waters are dependent upon several chemical equilibria processes including oxidation and reduction; precipitation and solution of hydroxides, carbonates, and sulfides; complex formation especially with organic material; and the metabolism of plants and animals. Dissolved iron concentra$t i o n s$ in oxygenated surface waters seldom are as as much $1 \mathrm{mg} / \mathrm{L}$. Some ground waters, unoxygenated surface waters such as deep waters of stratified lakes and reservoirs, and acidic waters resulting from discharge of industrial wastes or drainage from mines may contain considerably more iron. Corrosion of iron casings, pumps, and pipes may add iron to water pumped from wells.

Calcium is widely distributed in the comnon minerals of rocks and soils and is the principal cation in many natural freshwaters, especially those that contact deposits or soils originating from limestone, dolomite, gypsum, and gypsiferous shale. Calcium concentrations in freshwaters usually range from zero to several hundred milligrams per liter. Larger concentrations are not uncommon in waters in arid regions, especially in areas where some of the more soluble rock types are present.

Magnesium ranks eight among the elements in order of abundance in the Earth's crust and is a common constituent in natural water. Ferromagnesian minerals in igneous rocks and magnesium carbonate in carbonate rocks are two of the more important sources of magnesium in natural waters. Magnesium concentrations in freshwaters usually range from zero to several hundred milligrams per liter; but larger concentrations are not uncommon in waters assiciated with limestone or dolomite.

Sodium is an abundant and widespread constituent of many soils and rocks and is the principal cation in many natural waters associated with argillaceous sediments, marine shales, and evaporites and in sea water. Sodium saits are very soluble and once in solution tend to stay in solution. Sodium concentrations in natural waters vary from less than $1 \mathrm{mg} / \mathrm{L}$ in stream runoff from areas of high rainfall to more than $100,000 \mathrm{mg} / \mathrm{L}$ in ground and surface waters associated with halite deposits in arid areas. In addition to natural sources of sodium, sewage, industrial effluents, oilfield brines, and deicing salts may contribute sodium to surface and ground waters.
Although sillica in some domestic and industrial water supplies may inhibit corrosion of tron pipes by forming protective coatings, it generally is objectionable in industrial supplies, particularly in boiler feedwater, because it may form hard scale in boilers and pipes or deposit in the tubes of heaters and on steam-turbine blades.

Iron is an objectionable constituent in water supplies for domestic use because it may adversely affect the taste of water and beverages and stain laundered clothes and plumbing fixtures. According to the National Secondary Drinking Water Regulations proposed by the U.S. Environmental Protection Agency (1977b), the secondary maximum contamination level of iron for public water systems is $300 \mathrm{ug} / \mathrm{L}$. Iron also is undesirable in sone industrial water supplies, particularly in waters used in high-pressure bollers and those used for food processing, production of paper an chemicals, and bleaching or dyeing of textiles.

Calcium contributes to the total hardness of water. Small concentrations of calcium carbonate combat corrosion of metallic pipes by forming protective coatings. Calcium in domestic water supplies is objectionable because it tends to cause incrustations on cooking utensils and water heaters and increases soap or detergent consumption in waters used for washing, bathing, and laundering. Calcium also is undesirable in some industrial water supplies, particularly in waters used by electroplating, textile, pulp and paper, and brewing industries and in waters used in highpressure boilers.

Magnesium contributes to the total hardness of water. Large concentrations of magnesium are objectionable in domest ic water supplies because they can exert a cathartic and diuretic action upon unacclimated users and increase soap or detergent consumption in waters used for washing, bathing, and laundering. Magnesium also is undesirable in some industrial supplies, particularly in waters used by textile, pulp and paper, and brewing industries and in water used in highpressure boilers.

Sodium in drinking water may impart a salty taste and may be harmful to persons suffering from cardiac, renal, and circulatory diseases and to women with toxemias of pregancy. Sodium is objectionable in boiler feedwaters because it may cause foaming. Large sodium concentrations are toxic to most plants; a large ratio of sodium to total cations in irrigation waters may decrease the permeability of the soll, increase the $\mathrm{pH}$ of the soll solution, and impair drainage. 
10.0 SUPPLEMENTAL DATA

10.7 Source and Significance of Selected Constituents and Properties Commonly Reported in Water Analyses $1 /$-Cont inued

Coristituent

or property Source or cause Significance

Potassium Although potassium is only slightly less common (K)

Alkalinity

Sulfate

$\left(\mathrm{SO}_{4}\right)$

Chloride

(CI) than sodium and is more easily adsorbed by clay products. Potassium concentrations more than 20 iarger concentrations are not uncommon in brines or in water from hot springs. extent by hydroxide and minor acid radicals such and usually can be attributed to contamination. The alkalinity of natural waters varies widely but rarely exceeds 400 to $500 \mathrm{mg} / \mathrm{L}$ as $\mathrm{CaCO}_{3}$. igneous and sedimentary rocks. Weathering of metallic sulfides such as pyrite by oxygenated water yields sulfate ions to the water. Sulfate is dissolved also from soils and evaporite sediconcentration in natural freshwaters may range Drainage from mines may add sulfate to waters by virtue of pyrite oxidation. but is the predominant anion in sea water, most than sodium in 1 gneous rocks and is more abundant in sedimentary rocks, the concentration of potassium in most natural waters is much smaller than the concentration of sodium. Potassium is liberated from silicate minerals with greater difficulty minerals and reincorporated into solid weathering $\mathrm{mg} / \mathrm{L}$ are unusual in natural freshwaters, but much

Alkalinity is a measure of the capacity of a water to neutralize a strong acid, usually to $\mathrm{pH}$ of 4.5 , and is expressed in terms of an equivalent concentration of calcium carbonate $\left(\mathrm{CaCO}_{3}\right)$. Alkalinity natural waters usually is caused by the presence of bicarbonate and carbonate jons and to a lesser as borates, phosphates, and silicates. Carbonates and bicarbonates are common to most natural waters because of the abundance of carbon dioxide and carbonate minerals in nature. Direct contribution to alkalinity in natural waters by hydroxide is rare

Sulfur is a minor constituent of the Earth's crust but is widely distributed as metallic sulfides in ments containing gypsum or anhydrite. The sulfate from zero to several thcisalu milligrams per liter.

Chloride is relatively scarce in the Earth's crust petroleum-associated brines, and in many natural freshwaters, particularly those associated with marine shales and evaporites. Chloride salts are very soluble and once in solution tend to stay in solution. Chloride concentrations in natural waters vary from less than $1 \mathrm{mg} / \mathrm{L}$ in stream runoff from humid areas of high rainfall to more than $100,000 \mathrm{mg} / \mathrm{L}$ in ground and surface waters associated with evaporites in arid areas. The discharge of human, animal, or industrial wastes and irrigation return flows may add significant quantities of chloride to surface and ground waters.
Large concentrations of potassium in drinking water may impart a salty taste and act as a cathartic, but the range of potassium concentrations in most domestic supplies seldom cause these problems. Potassium is objectionable in boiler feedwaters because it may cause foaming. In irrigation water, potassium and sodium act similarly upon the soil, although potassium generally is considered less harmful than sodium.

High alkaline waters may have a distinctive unpleasant taste. Alkalinity is detrimental in several industrial processes, especially those involving the production of food and carbonated or acid-fruit beverages. The alkalinity of irrigation waters in excess of alkaline earth concentrations may increase the $\mathrm{pH}$ of the soil solution, leach organic material, decrease permeability of the soil, and impair plant growth.

Sulfate in drinking water may impart a bitter taste and act as a laxative on unacclimated users. According to the National Secondary Orinking Water Regulations proposed by the Environinental Protection Agency (1977b) the secondary maximum contaminant level of sulfate for public water systems is $250 \mathrm{mg} / \mathrm{L}$. Sulfate also is undesirable in some industrial supplies, particularly in waters used for the production of concrete, ice, sugar, and carbonated beverages and in waters used in high-pressure boilers.

Chloride may impart a salty taste to drinking water and may accelerate the corrosion of metals used in water-supply systems. According to the National Secondary Orinking Water Regulations proposed by the Environmental Protection Agency (1977b) the secondary maximuin contaminant level of chloride for public water systems is $250 \mathrm{mg} / \mathrm{L}$. Chloride also is objectionable in some industrial supplies, particularly those used for brewing and food processing, paper and steel production, and textile processing. Chloride in irrigation waters generally is not toxic to most crops but may be injurious to citrus and stone fruits. 


\subsection{SUPPLEMENTAL DATA}

10.7 Source and Significance of Selected Constituents and Properties Commonly Reported in Water Analyses $1 /$-Continued

Constituent

or prope

Fluoride

(F)

Fluoride is a minor constituent of the earth's crust. The calcium fluoride mineral fluorite is a widespread constituent of resistate sediments and igneous rocks, but its solubility in water is negligible. Fluoride comonly is associated with volcanic gases, and volcanic emaniations may be important sources of fluoride in some areas. The fluoride concentration in fresh surface waters usually is less than $1 \mathrm{mg} / \mathrm{L}$; but larger concentrations are not uncommon in sal ine water from oil wells, ground water from a wide variety of geologic terranes, and water from areas affected by volcantsm.

Nitrogen

(N)

A considerable part of the total nitrogen of the earth is present as nitrogen gas in the atmosphere. Small amounts of nitrogen are present in rocks, but the element is concentrated to a greater extent in soils or biological material. Nitrogen is a cyclic element and may occur in water in several forms. The forms of greatest interest in water in order of increasing oxidation state, include organic nitrogen, ammonia nitrogen $\left(\mathrm{NH}_{4}-\mathrm{N}\right)$, nitrite nitrogen ( $\mathrm{NO}_{2}-\mathrm{N}$ ) and nitrate nitrogen $\left(\mathrm{NO}_{3}-\mathrm{N}\right)$. These forms of nitrogen in water may be derived naturally from the leaching of rocks, soils, and decaying vegetation; from rainfall; or from biochemical conversion of one form to another Other inportant sources of nitrogen in water include effluent from waste-water treatment plants, sept ic tanks, and cesspools and drainage from barnyards, feed lots, and fertilized fields. $\mathrm{Ni}-$ trate is the most stable form of nitrogen in an oxidizing environinent and is usually the dominant form of nitrogen in natural waters and in polluted waters that have under gone self-purification or aerobic treatment processes. Significant quantities of reduced nitrogen often are present in some ground waters, deep unoxygenated waters of strat 1fied lakes and reservoirs, and waters containing partially stabilized sewage or animal wastes.

Phosphorus

Phosphorus is a major component of the mineral apatite, which is widespread in igneous rock and marine sediments. Phosphorus also is a component of household detergents, fertilizers, human and animal metabol ic wastes, and other biological material. Although small concentrations of phosphorus may occur naturaliy in water as a result of leaching from rocks, solls, and decaying vegetation, larger concentrations are likely to occur as a result of pollution.
Significance

Fluoride in drinking water reduces the incidence of tooth decay when the water is consumed during the period of enamel calcification. Excessive quantities in drinking water consumed by children during the period of enamel calcification may cause a characteristic discoloration (mottling) of the teeth. According to the National Interim Primary Drinking Water Regulations established by the Environmental Protection Agency (1977a) the maximum contaminant level of fluoride in drinking water varies from 1.4 to $2.4 \mathrm{mg} / \mathrm{L}$, depending upon the annual average of the maximum daily air temperature for the area in which the water system is located. Excessive fluoride is also objectionable in water supplies for some industries, particularly those involved in the production of food, beverages, and pharmaceutical items.

Concentrations in water of any of thee forms of nitrogen significantly greater than the local average may suggest pollution. Nitrate and $n i$ trite are objectionable in drinking water because of the potential risk to bottle-fed infants for methemoglobinemia, a sometimes fatal illness related to the impairment of the oxygen-carrying ability of the blood. According to the National Interim Primary Drinking Water Regulations (U.S. Environmental Protection Agency, 1977a), the maximum contaminant level of nitrate (as $N$ ) in drinking water is $10 \mathrm{mg} / \mathrm{L}$. Although a maximum contaminant level for nitrite is not specified in the drinking water regulations. Appendix $A$ to the regulations (U.S. Environinental Protection Agency, 1977a) indicates that waters with nitrite concentrations (as $N$ ) greater than $1 \mathrm{mg} / \mathrm{L}$ should not be used for infant feeding. Excessive nitrate and nitrite concentrations are also objectionable in water supplies for some industries, particularly in waters used for the dyeing of wool and silk fabrics and for brewing.

Phosphorus stimulates the growth of algae and other nuisance aquatic plant growth, which may impart undesirable tastes and odor to the water, become aesthetically unpleasant, alter the chemistry of the water supply, and affect water treatment processes. 
10.7 Source and Significance of Selected Constituents and Properties Commonly Reported in Water Analyses $1 /$-Continued

\begin{tabular}{|c|c|}
\hline $\begin{array}{l}\text { Constituent } \\
\text { or property }\end{array}$ & Source or cause \\
\hline $\begin{array}{l}\text { Dissolved } \\
\text { solids }\end{array}$ & $\begin{array}{l}\text { Theoretically, dissolved solids are anhydrous res- } \\
\text { idues of the dissolved substance in water. In } \\
\text { reality, the term "dissolved solids" is defined by } \\
\text { the method used in the determination. In most } \\
\text { waters, the dissolved solids consist predominantly } \\
\text { of silica, calcium, magnesium, sodium, potassium, } \\
\text { carbonate, bicarbonate, chloride, and sulfate with } \\
\text { minor or trace amounts of other inorganic and } \\
\text { organic constituents. In regions of high rainfall } \\
\text { and relatively insoluble rocks, waters may contain } \\
\text { dissolved-solids concentrations of less than } 25 \\
\text { mg/L; but saturated sodium chloride brines in } \\
\text { other areas may contain more than } 300,000 \text { mg/L. }\end{array}$ \\
\hline
\end{tabular}

Specific conductance (micromhos at $25^{\circ} \mathrm{C}$ )

Hardness as $\mathrm{CaCO}_{3}$
Specific conductance is a measure of the ability of a water to carry an electrical current and depends on the concentrations of ionized constituents dissolved in the water. Many natural waters in contact only with granite, well-leached soil, or other sparingly soluble material have a conductance of less than 50 micromhos. The specific conductance of some brines exceed several hundred thousand micromhos.

Hardness of water is attributable to all polyvalent metals but principally to calcium and magnesium ions expressed as $\mathrm{CaCO}_{3}$ (calcium carbonate). Water hardness results naturally from the solution of calcium and magnesium, both of which are widely distributed in common minerals of rocks and soils. Hardness of waters in contact with limestone often exceeds $200 \mathrm{mg} / \mathrm{L}$. In waters from gypsiferous formations, $1,000 \mathrm{mg} / \mathrm{L}$ is not uncommon.

\author{
Significance
}

Dissolved-solids values are used widely in evaluating water quality and in comparing waters.

The following classification based on the concentrations of dissolved solids commonly is used by the Geological Survey.

\begin{tabular}{lr} 
Classification & $\begin{array}{r}\text { Dissolved-solids } \\
\text { concentration (mg/L) }\end{array}$ \\
\cline { 2 - 2 } Fresh & $1,000-3,000$ \\
Slightly saline & $3,000-10,000$ \\
Moderately saline & $10,000-35,000$ \\
Very saline & $>35,000-$
\end{tabular}

The National Secondary Drinking Water Regulations (U.S. Environmental Protection Agency, 1977b) set a dissolved-solids concentration of $500 \mathrm{mg} / \mathrm{L}$ as the secondary maximum contaminant level for public water systems. This level was set primarily on the basis of taste thresholds and potential physiological effects, particularly the laxative effect on unacclimated users. Although drinking waters containing more than $500 \mathrm{mg} / \mathrm{L}$ are undesirable, such waters have been used in many areas where less mineralized supplies are not avallable without any obvious $i l l$ effects. Dissolved solids in industrial water supplies can cause foaming in boilers; interfere with clearness, color, or taste of many finished products; and accelerate corrosion. Uses of water for irrigation also are limited by excessive dissolvedsolids concentrations. Dissolved solids in Trrigation water may adversely affect plants directly by the development of high osmotic conditions in the soil solution and the presence of phytoxins in the water or indirectiy by their effect on soils.

The specific conductance is an indication of the degree of mineralization of a water and may be used to estimate the concentration of dissolved solids in the water.

Hardness values are used in evaluating water quality and in comparing waters. The following classification is commonly used by the Geological Survey.

$\begin{array}{cl}\text { Hardness }\left(\mathrm{mg} / \mathrm{L} \text { as } \mathrm{CaCO}_{3}\right) & \frac{\text { Classification }}{00 \mathrm{ft}} \\ 61-120 & \text { Moderately hard } \\ 121-180 & \text { Hard } \\ >180 & \text { Very Hard }\end{array}$

Excessive hardness of water for domestic use is objectionable because it causes incrustations on cooking utensils and water heaters and increased soap or detergent consumption. Excessive hardness is undesirable also in many industrial supplies. (See discussions concerning calcium and magnesium.)' 


\subsection{SUPPLEMENTAL DATA}

10.) Source and Significance of Selected Constituents and Properties Commonly Reported in Water Analyses $1 /$-.Cont inued

Constituent

or property

Source or cause

Significance

$\mathrm{pH}$

The $\mathrm{pH}$ of a solution is a measure of its hydrogen

ion activity. By definition, the $\mathrm{pH}$ of pure water at a temperature of $25^{\circ} \mathrm{C}$ is 7.00 . Natural waters contain dissolved gases and minerals, and the $\mathrm{pH}$ may deviate significantly from that of pure water. Rainwater not affected significantly by atmospheric pollution generally has a pH of 5.6 due to the solution of carbon dioxide from the atmosphere. The $\mathrm{pH}$ range of most natural surface and ground waters is about 6.0 to 8.5 . Many natural waters are slightly basic $(\mathrm{pH}>7.0)$ because of the prevalence of carbonates and bicarbonates, which tend to increase the $\mathrm{pH}$.

1/ Most of the material in this table has been summarized from several references. For a more thorough discussion of the source and significance of these and other water-quality properties and constituents, the reader is referred to the following additional references: American Public Health Association and others (1975); Hem (1970): Mckee and Wolf (1963); National Academy of Science, National Academy of Engineering (1974); National Technical Advisory Committee to the Secretary of the Interior (1968); and U.S. Environmental Protection Agency (1976, 1977a,b). 
10.8 Chemical Analysis of the Overburden and Lignite from 0 to 255 Feet at Well $C-13$ 1/

\section{OVERBURDEN}

$[\mu \mathrm{g} / \mathrm{g}$, micrograms per grams; meq/L, milliequivalents per liter; $\%$, percent; $\% / w t$., percent per weight; $1 \mathrm{~b}$, pound]

Chemical parameters

$1: 1$ water extract $\underline{2} /$

$\mathrm{PH}$ (units)

Salinity $\mu \mathrm{g} / \mathrm{g}$

Calcium

Magnesium

Sodium

Potassium

Carbonate

Bicarbonate

Chloride

Sulfate

Cation exchange capacity, meq $/ 100 \mathrm{~g}$

Total exchangeable basis, meq/100g

Total sulfur, \%/wt.

Sulfate sulfur, \%/wt.

Pyritic sulfur, $\% / w t$.

Organic sulfur, \%/wt.

Neutralization poten- 1

tial, tons of

$\mathrm{CaCO}_{3} / 1,000$ tons soil

$\begin{array}{ccc}6.3 & 6.0 & 6.2 \\ 230 & 3,600 & 3,000 \\ 11 & 276 & 212 \\ 3.9 & 109 & 83.5 \\ 39 & 362 & 292 \\ 5.9 & 32.3 & 26.9 \\ 0 & 0 & 0 \\ 49 & 20 & 59 \\ 24 & 417 & 350 \\ 60 & 1,300 & 960\end{array}$

14.0

19.9

4.5

9.0

20.4

7.5
2,100
159
63.1
185
27.4
0
171
24.8
580

7.3
1,900
154
59.0
224
24.6
0
171
256
620

6.8
2,000
215
79.0
91
24.6
0
93
176
800

19.4

8.6

25.5

15.7

9.1

.26

.05

.17

.04

$<.1$

.06

.42

.10

.34

.26

.06

1.5

4
.20

.02

.14

.04

2.5
90 to

105 
10.0 SUPPLEMENTAL DATA--Continued

10.8 Chemical Analysis of the Overburden and Lignite from 0 to 255 Feet at Well C-13 1/--Continued

OVERBURDEN--Cont inued

Chemical Depth interval (feet)

Chemical parameters 105 to 120 to 135 to 180 to 195 to 210 to

$1: 1$ water extract $\underline{2 /}$

$\begin{array}{llcccc}120 & 135 & 150 & 193 & 210 & 225.7\end{array}$

$234.5 \quad 239$ to

255

$\mathrm{PH}$ (units)

Sal inity, $\mu \mathrm{g} / \mathrm{g}$

Calcium

Magnesium

Sodium

Potassium

Carbonate

Bicarbonate

Chloride

Sulfate

$\begin{array}{cccccc}6.9 & 7.9 & 6.6 & 7.2 & 7.4 & 7.3 \\ 1,500 & 1,190 & 1,600 & 430 & 1,320 & 560 \\ 186 & 131 & 188 & 37 & 240 & 51\end{array}$

$\begin{array}{rrrrrr}63.8 & 49.4 & 45.2 & 10.3 & 38.0 & 14.3\end{array}$

$\begin{array}{llllll}27 & 48 & 84 & 36 & 56 & 45\end{array}$

$\begin{array}{llllll}26.3 & 21.5 & 40.0 & 11.7 & 36.8 & 13.4\end{array}$

$\begin{array}{cccccc}0 & 0 & 0 & 0 & 0 & 0\end{array}$

$\begin{array}{llllll}122 & 239 & 176 & 146 & 508 & 137\end{array}$

$\begin{array}{rrrrrr}30 & 4 & 32 & 2 & 32 & 12\end{array}$

$\begin{array}{llll}650 & 442 & 640 & 100\end{array}$

$356 \quad 164$

Cation exchange capacity, meq/100g

Total exchangeable basis, meq/100g

Total sulfur, $\% / w t$. $\mathrm{SO}_{4}-\mathrm{S}$

$20.2 \quad 23.4 \quad 33.5 \quad 11.6$

25.0

18.9

17.5

9.1

$\begin{array}{llll}9.4 & 11.1 & 11.7 & 17.5\end{array}$

.42

$\begin{array}{llll}.42 & .59 & .74 & .31\end{array}$

.13

.43

.13

.14

Pyritic sulfur, \%/wt.

$.36 \quad .19$

.23

7.7
510
50

13.8

39

13.8

0

205

10

100

6.7

$.33 \quad .39$

$2.0 \quad 8.5$

13.5

1.0

21.4

380

33

8.0

Neutralization poten-

$1.0 \quad 3.0$

8.5

$\mathrm{CaCO}_{3} / 1,000$ tons soil

See footnotes at end of section. 
10.0 SUPPLEMENTAL DATA--Continued

10.8 Chemical Analysis of the Overburden and Lignite from 0 to 255 Feet at Well C-13 1/--Continued

OVERBURDEN--Continued

\begin{tabular}{|c|c|c|c|c|c|c|c|}
\hline \multirow{2}{*}{ Trace elements 2.} & \multicolumn{7}{|c|}{ Depth interval (feet) } \\
\hline & $\begin{array}{c}0 \text { to } \\
15 \\
\end{array}$ & $\begin{array}{c}15 \text { to } \\
30 \\
\end{array}$ & $\begin{array}{c}30 \text { to } \\
45 \\
\end{array}$ & $\begin{array}{c}45 \text { to } \\
60 \\
\end{array}$ & $\begin{array}{c}60 \text { to } \\
75 \\
\end{array}$ & $\begin{array}{c}75 \text { to } \\
90 \\
\end{array}$ & $\begin{array}{c}90 \text { to } \\
105 \\
\end{array}$ \\
\hline Cadmi um, $\mu \mathrm{g} / \mathrm{g}$ & 0.1 & 0.2 & 0.1 & 0.3 & 0.1 & 0.3 & 0.2 \\
\hline Copper & 9 & 7 & 8 & 10 & 11 & 9 & 8 \\
\hline Chromi um & 8 & 7 & 8 & 7 & 9 & 8 & 8 \\
\hline Lead & .51 & .21 & & .43 & & .09 & $\bullet$ \\
\hline Manganese & 135 & 163 & 122 & 559 & 413 & 37 & 49 \\
\hline Molybdenum & $<2$ & $<2$ & 3 & $<2$ & $<2$ & $<2$ & 2 \\
\hline Zinc & 27 & 62 & 46 & 52 & 57 & 47 & 50 \\
\hline Arsenic & 9.2 & 7.4 & 9.3 & 6.2 & 7.7 & 7.6 & 9.5 \\
\hline Selenium & .87 & .88 & .84 & 1.7 & .82 & 1.0 & 1.1 \\
\hline Boron & 4.6 & 9.3 & 15 & 9.8 & 11 & 24 & 13 \\
\hline
\end{tabular}

Physical parameters

Texture

$\%$ sand

$\%$ silt

$\%$ clay

$65 \quad 40$

$18 \quad 34$

$17 \quad 26$

37

43

20

25

57

18

22

62

36

31

10

46

18

52

17

Water holding capacity, \%/wt.

$1 / 3$ bar

15 bar

Available moisture

See footnotes at end of section.

$\begin{array}{rrrrrrr}19.4 & 28.4 & 26.0 & 28.7 & 24.6 & 28.5 & 26.0 \\ 11.9 & 16.3 & 14.8 & 16.5 & 14.8 & 17.6 & 15.0 \\ 7.5 & 12.1 & 11.2 & 12.2 & 9.8 & 11.0 & 11.0\end{array}$


10.0 SUPPLEMENTAL DATA--Continued

10.8 Chemical Analysis of the Overburden and Lignite from 0 to 255 Feet at Well $\mathrm{C}-13$ 1/--Continued

OVERBURDEN--Continued

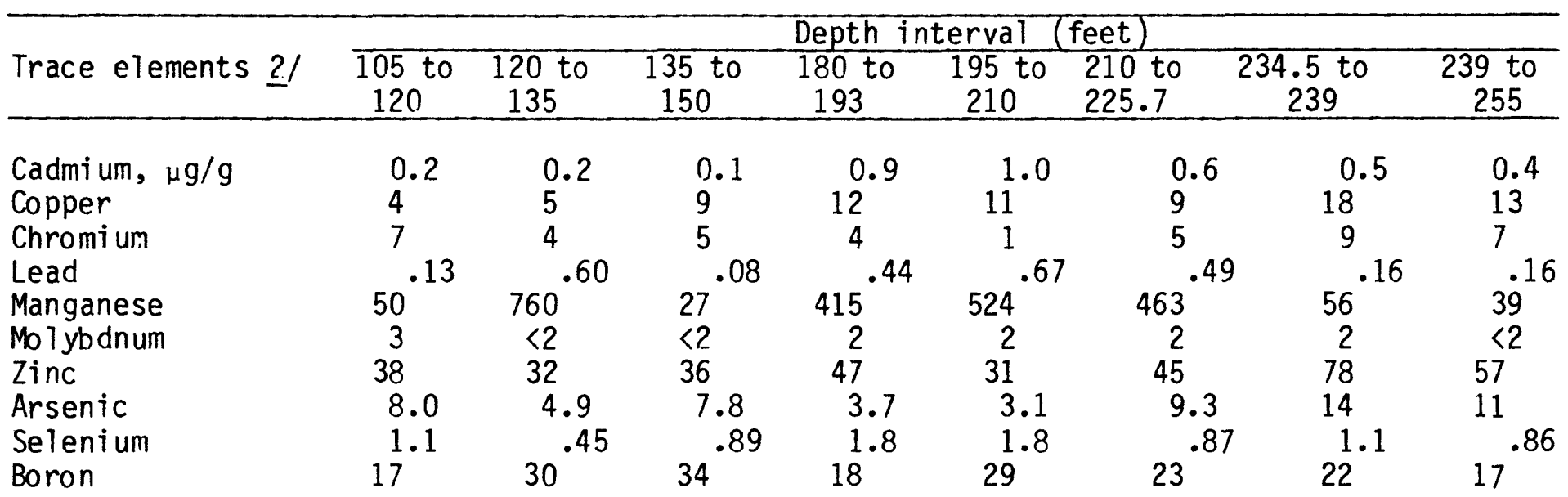

Physical parameters

Texture

$\%$ sand

$\%$ silt

$\%$ clay

Water holding capacity, $\% /$ wt.

$1 / 3$ bar

15 bar

Available moisture $\quad 10.4$

25.1

14.7

25.1

45

39

16

15.8

29.4

17.4

$9.3 \quad 12.0$

12.1

29.8

17.7

27.1

18.3

26.8

15.0

8.9

11.8

26

58

16

36
18

8.9
19

55

26

25

49

26

See footnotes at end of section. 
10.0 SUPPLEMENTAL DATA--Cont inued

10.8 Chemical Analysis of the Overburden and Lignite

from 0 to 255 Feet at Well C-13 1/--Cont inued

\section{LIGNITE}

\begin{tabular}{|c|c|c|c|c|c|c|}
\hline \multirow{2}{*}{ Trace elements $\underline{2} /$} & \multirow[b]{2}{*}{$\begin{array}{c}91.5 \text { to } \\
93.1 \\
\end{array}$} & & \multicolumn{3}{|c|}{ Depth interval (feet) } & \multirow[b]{2}{*}{$\begin{array}{c}234.5 \text { to } \\
239 \\
\end{array}$} \\
\hline & & $\begin{array}{l}135.2 \text { to } \\
136.2\end{array}$ & $\begin{array}{c}184.5 \text { to } \\
190.7\end{array}$ & $\begin{array}{c}223.3 \text { to } \\
225.7\end{array}$ & $\begin{array}{l}225.7 \text { to } \\
230.5\end{array}$ & \\
\hline Arsenic, $\mu \mathrm{g} / \mathrm{g}$ & 5.5 & 10 & 6.4 & 2.7 & 3.6 & 2.5 \\
\hline $\begin{array}{l}\text { Boron } \\
\text { Cadmium }\end{array}$ & & 43.2 & ${ }^{140} .3$ & 164.3 & 189 & $194_{4}$ \\
\hline Chromium & $6^{\circ}$ & $16^{\circ 2}$ & 2 & $3^{\cdot 0}$ & $1^{.4}$ & $<1^{.4}$ \\
\hline Copper & 5 & 2 & 2 & 3 & 2 & $<1$ \\
\hline Lead & .13 & .15 & .16 & .13 & .19 & - \\
\hline Manganese & 11 & 26 & 13 & 21 & 91 & 33 \\
\hline Mol ybdenum & $<2$ & $<2$ & $<2$ & $<2$ & $<2$ & $<2$ \\
\hline Mercury & .35 & .07 & .14 & .43 & .31 & .26 \\
\hline Selenium & 1.3 & .83 & 1.1 & 1.3 & 1.2 & 1.3 \\
\hline Zinc & 14 & 31 & 7 & 7 & 11 & 8 \\
\hline Uranium & 1.4 & 1.3 & .3 & .1 & $<.05$ & .1 \\
\hline PH & 5.9 & 6.4 & 6.0 & 6.0 & 5.9 & 6.0 \\
\hline \multicolumn{7}{|l|}{ Sulphur forms } \\
\hline Sulfate-S, $\% / w t$. & .01 & .02 & .02 & .02 & .01 & .01 \\
\hline Pyritic-S, $\% /$ wt. & .16 & .60 & .60 & .35 & .63 & .31 \\
\hline Organic-S, \%/wt. & .98 & .26 & 1.26 & 1.50 & 1.46 & 1.70 \\
\hline Total sulfur, $\% / w t$. & 1.15 & .88 & 1.88 & 1.87 & 2.10 & 2.02 \\
\hline
\end{tabular}

See footnotes at end of section. 
10.0 SUPPLEMENTAL DATA--Cont inued

10.8 Chemical Analysis of the Overburden and Lignite from 0 to 255 Feet at Well $\mathrm{C}-13$ 1/--Continued

LIGNITE

Proximate

As received

Dry basis

Identification: Camp Swift, Tex. Depth interval (feet): 91.5 to 93.1

Moisture, $\% / w t$.

35.04

Ash, \%/wt.

15.78

24.28

Sulfur, \%/wt.

.76

1.17

Gross heat of combustion, BTU/1b

6,849

10,540

Identification: Camp Swift, Tex. Depth interval (feet): 135.2 to 136.2

Moisture, $\% / w t$.

21.67

Ash, \%/wt.

54.92

70.13

Sulfur, \%/wt.

.656

.838

Gross heat of combustion, BTU/7b

6,053

7,730

See footnotes at end of section. 
10.0 SUPPLEMENTAL DATA--Continued

10.8 Chemical Analysis of the Overburden and Lignite from 0 to 255 Feet at Well C-13 1/--Cont inued

LIGNITE

Proximate

As received

Dry basis

Identification: Camp Swift, Tex. Depth interval (feet): 184.5 to 190.7

Moisture, $\% / w t$.

42.84

Ash, $\% /$ wt.

16.56

28.56

Sulfur, $\% /$ wt.

.98

1.71

Gross Heat of Combustion, BTU/Lb.

5.709

9,986

Identification: Camp Swift, Tex. Depth interval (feet): 223.3-225.7

Moisture, \%/wt.

35.69

Ash, $\% / w t$.

11.73

18.23

Sulfur, $\% / w t$.

1.48

2.30

Gross heat of combustion, BTU/lb

7,667

11,921

See footnotes at end of section. 
10.0 SUPPLEMENTAL DATA--Continued

10.8 Chemical Analysis of the Overburden and Lignite from 0 to 255 Feet at Well C-13 1/--Cont inued

\section{LIGNITE}

Proximate

As received

Dry basis

Identification: Camp Swift, Tex. Depth interval (feet): 225.7 to 230.5

Moisture, $\% /$ wt.

Ash, $\% /$ wt.

Sulfur, \%/wt.

Gross Heat of Combustion, BTU/Lb.
33.94

11.37

1.62

7,807

11,820

Identification: Camp Swift, Tex. Depth interval (feet): 234.5-239

Moisture, \%/wt.

Ash, \%/wt.

Sulfur, \%/wt.

Gross heat of combustion, BTU/Ib
36.79

10.71

1.30

7,121

1/ Analyses by Southwestern Laboratories, Dallas, Texas.

2f All results are figured on a dry basis, acid soluble. 
The glossary is composed of four separate sections:

11.1 Geological- and GroundWater-Related Terms

11.2 Surface-Water and Related Terms

11.3 Water-Quality-Related Terms

11.4 Sediment-Related Terms

Definitions used in these glossaries are derived from the following publications:
Glossary of geology, second edition (American Geological Institute, 1980);

Handbook of applied hydrology (Chow, ed., 1964);

A dictionary of mining, mineral, and related terms (Thrush, 1968); General introduction and hydrologic definitions (Langbein and Iseri, 1960); and

Water data for Texas (U.S. Geological Survey, 1982). 
11.1 Geological-and Ground-Water-Related Terms

Alluvium or alluvial deposits.-Sediments deposited by streains; includes flood-plain deposits.

Aquifer.--A formation, group of formations, or part of a formation that will yield water in sufficient quantity to be of value as a source of supply.

Artesian aquifer (confined aquifer). --An aquifer which is overlain (confined) by confining layer so that the water is under hydrostatic pressure. The water level in an artesian well will rise above the top of the aquifer to the level of the potentiometric surface; however, the well may or may not flow.

Avulsion.--A sudden separation of 1 and by a flood or by an abrupt change in the course of a stream, as by a stream breaking through a meander or by a sudden change in current whereby the stream deserts its old channel for a new one.

Bifurcation.--(a) The separation or branching of a stream into two parts.

(b) A stream branch produced by bifurcation.

Cone of depression.--Depression of the water table or potentiometric surface surrounding a discharge well which is more or less the shape of an inverted cone.

Confining bed or formation.--One which, because of its position and its minimal impermeability relative to that of the aquifer, confines the water in the aquifer under artesian pressure.

Crevasse splay (flood-plain splay) --A small alluvial fan or other outspread deposit formed where a stream breaks through a levee (artificial or natural) and deposits its material (commonly coarse-grained) on the flood plain.

Delta.--The low, nearly flat, alluvial tract of land at or near the mouth of a river, commonly forming a triangular or fan-shaped plain of considerable area, crossed by many distributaries of the main river, perhaps extending beyond the general trend of the coast, and resulting from the accumulation of sediment supplied by the river in such quantities that it is not removed by tides, waves, and currents.

Dendritic drainage pattern.--A drainage pattern in which the streams branch randomly in all directions and at almost any angle, resembling in plan the branching habit of certain trees; it is produced where a consequent stream receives several tributaries which in turn have smaller tributaries. It is indicative of insequent streams flowing across horizontal and homogeneous strata or complex crystalline rocks with uniforin resistance to erosion.

Dip of rocks.--The anyle of slope at which a bed is inclined from the horizontal; direction also is expressed (such as $1.0^{\circ}$, southeast; or 90 feet per mile, southeast).

Drawdown.--The lowering of the water table or potentiometric surface caused by pumping or artesian flow. It is the difference, in feet, between the static level and the pumping level.

Electric log. - - A geophysical log showing the electrical properties of the rocks and their fluid contents penetrated in a well. The electrical properties are natural potentials and resistivities to induced electrical currents, some of which are modified by the presence of the drilling mud in and near the borehole. 
11.1 Geological- and Ground-Water-Related Terms--Continued

Fault.--A fracture or fracture zone in a rock or body of rock along which there has been displacement of the two sides relative to one another parallel to the surface of the fracture.

Fluvial.--(a) of or pertaining to a river or rivers. (b) Existing, growing, or living in or about a stream or river. (c) Produced by the action of a stream or river.

Formation.--A body of rock that is sufficientTy homogeneous or distinctive to be regarded as a mappable unit.

Graben.--A elongate, relatively depressed crustal unit or block that is bounded by faults on its long sides. It is a structural form that may or may not be geomorphologically expressed as a rift valley. Etymo 1: German, "ditch". CF: horst. Syn: Trough [fault].

Ground water.--Water in the ground that is in the zone of saturation from which wells, springs, and seeps are supplied.

Head, or hydrostatic pressure.-The height of the water table or potentiometric surface above the base of the aquifer.

Hydraulic conductivity. --The rate of flow of water, in gallons per day, through a cross sectional area of 1.0 square foot under a unit hydraulic gradient.

Hydraulic gradient.--The slope of the water table or potentiometric surface, usually given in feet per mile.

Infiltration.--The flow of a fluid into a substance through pores or small openings. It connotes flow into a substance in contradistinction to the word percolation, which connotes flow through a porous substance.
Lithology.--The description of rocks, usually from observation of hand specimen or outcrop.

Outcrop.--That part of a rock layer which appears at the land surface.

Percolation.--The movement, under hydrostatic pressure, of water through the interstices of a rock or soil, except the movement through large openings such as caves.

Permeable.--Pervious or having a texture that permits water to move through it perceptibly under the head differences ordinarily found in subsurface water. A permeable rock has connecting interstices of capillary or super-capillary size.

Porosity.--The ratio of the aggregate volume of interstices (openings) in a rock or soil to its total volume, usually stated as a percentage.

Recharge of ground water.--The process by which water is absorbed and is added to the zone of saturation. Also used to designate the quantity of water that is added to the zone of saturation.

Resistivity (electrical log).-The resistance of the rocks and their fluid content penetrated in a well to induced electrical currents. Permeable rocks containing freshwater have high resistivities.

Slip.--(a) The relative displacement of formerly adjacent points on opposite sides of a fault, measured in the fault surface. Partial syn: Shift. Syn: Total displacement. (b) A small fracture along which there has been some displacement.

Specific capacity.--The rate of yield of a weli per unit of drawdown, usually expressed as gallons per minute per foot of drawdown. If the yield is 250 gallons per minute and 


\subsection{Geological- and Ground-Water-Related Terms--Cont inued}

the drawdown is 10 feet, the specific capacity is 25 gallons per minute per foot.

Specific yield.--The quantity of water that an aquifer will yield by gravity if it is first saturated and then allowed to drain; the ratio expressed in percentage of the volume of water drained to volume of the aquifer that is drained.

Storage.--The volume of water in an aquifer, usually reported in acrefeet.

Storage coefficient.--The volume of water an aquifer releases from or takes into storage per unit of surface area of the aquifer per unit change in the component of head normal to that surface.

Strike.--The direction or trend taken by a structural surface, for example a bedding or fault plane, as it intersects the horizontal.

Throw.--The amount of vertical displacement caused by a fault.

Iransmissivity.--The volume of water that will move in 1 day through a vertical strip of the aquifer 1.0foot wide and having the height of the aquifer when the hydraulic gradient is unity. It is the product of the hydraulic conductivity and the saturated thickness of the aquifer expressed in feet squared per day.
Water level.--Usually expressed as the altitude of the water table or potentiometric surface above sea level. Under artesian conditions the water level may be below or above the 1 and surface.

Water table.--The upper surface of a zone of saturation except where the surface is formed by a confining bed.

water-table aquifer (unconfined aquifer).--An aquifer in which the water is unconfined; the upper surface of the zone of saturation is under atmospheric pressure only and the water is free to rise or fall in response to the changes in the volume of water in storage. A well penetrating an aquifer under water-table conditions becomes filled with water to the level of the water table. Yield of a well.--The rate of discharge, usually expressed in gallons per minute. In this report, yields are classified as small, less than 50 gallons per minute; inoderate, 50 to 500 gallons per minute; and large, more than 500 gallons per minute.

Zone of saturation.--The zone in which the functional permeable rocks are saturated with water under hydrostatic pressure. Water in the zone of saturation will flow into a well, and is called ground water. 


\subsection{Surface-Water and Related Terms}

Acre-foot.--The quantity of water required to cover 1 acre to a depth of 1 foot and is equivalent to 43,560 cubic feet or about 326,000 gallons.

Cubic foot per second per square mile. - - The average number of cubic feet of water flowing per second from each square mile of area drained, assuming that the runoff is distributed uniformly in time and area.

Cubic foot per second.--The rate of discharge representing a volume of 1 cubic foot passing a given point during 1 second. This rate is equivalent to approximately 7.48 gallons per second or 448.8 gallons per minute.

Discharge.--The volume of water (or more broadly, volume of fluid plus suspended sediment), that passes a given point within a given time.

Mean discharge.--The arithmetic mean of individual daily mean discharges during a specific period.

Instantaneous discharge.--The discharge at a particular instant of time.

Drainage area.--The area of a stream at a specified location, measured in a horizontal plane, enclosed by a topographic divide from which direct surface runoff from precipitation normally drains by gravity into the stream upstream from the specified location. Figures of drainage area given herein include all closed basins, or noncontributing areas, within the area unless otherwise noted.

Drainage basin.--A part of the surface of the Earth that is occupied by a drainage system, which consists of a surface stream or a body of impounded surface water together with all tributary surface streams and bodies of impounded surface water.
Evaporation.--The process by which water is changed from the 1iquid or the solid state into the vapor state. In hydrol ogy, evaporation is vaporization that takes place at a temperature less than the boiling point.

Evapotranspiration.--Water withdrawn from a land area by evaporation from water surfaces and moist soil and plant transpiration.

Gage height.--The water-surface elevation referred to some arbitrary gage datum. Gage height is often used interchangeably with the more general term "stage," although gage height is more appropriate when used with a reading on a gage.

Gaging station.--A particular site on a stream, canal, lake, or reservoir where systematic observations of hydrologic data are obtained.

Hydrograph. - A graph showing stage, flow, velocity, or other property of water with respect to time.

Mass curve.--A graph of the cummulative values of a hydrologic quantity (such as precipitation or runoff), generally as ordinate, plotted against time or date as abscissa. Runoff.--That part of the precipitation that appears in surface streams. It is the same as streamflow unaffected by artificial diversions, storage, or other works of man in or on the stream channels. Runoff in inches.--The depth to which the drainage area would be covered if all the runoff for a given time period were uniformly distributed on it.

Streamflow.--The discharge that occurs in a natural channel. Although the term "discharge" can be applied to the flow of a canal, the word "streamflow" uniquely describes the discharge in a surface stream 
11.0 GLOSSARY--Continued

\subsection{Surface-Water and Related Terms--Cont inued}

course. The term "streamflow" is more general than "runoff" as streamflow may be applied to discharge whether or not it is affected by diversion or regulation.

Transpiration.--The quantity of water absorbed and transpired and used directly in the building of plant tissue, in a specified time. It does not include soil evaporation. The process by which water vapor escapes from the living plant, principally the leaves, and enters the atmosphere.

Watershed.--Drainage basin. 


\subsection{Water-Quality-Related Terms}

Bacteria.--Micruscopic unicellular organisms, typically spherical, rodlike, or spiral and threadlike in shape, commonly clumped into colonies. Some bacteria cause disease, others perform an essential role in nature in the recycling of materials; for example by decomposing organic matter into a form available for reuse by plants.

Total coliforin bacteria.--A particular group of bacteria that are used as indicators of pussible sewage pollution. They are characterized as aerobic or facultative anaerobic, gram negative, nonspore-forming, rodshaped bacteria which ferment lactose with gas formation within 48 hours at $35^{\circ}$ Celsius. In the laboratory these bacteria are defined as the organisms that produce colonies with a goldengreen retallic sheen within 24 hours when incubated at $35^{\circ}+0.2^{\circ}$ Celsius on M-FC medium (nutrient medium for bacterial growth). Their concentrations are expressed as number of colonies per 100 milliliters of sample.

Fecal streptococcal bacteria.-Bacteria found in intestines of warmblooded animals. Their presence in water is considered to verify fecal pollution. They are characterized as gram-positive, cocci bacteria which are capable of growth in brain-heart infusion broth. In the laboratory they are defined as all the organisms which produce red or pink colonies within 48 hours at $35^{\circ}+1.0^{\circ}$ Celsius on M-enterrococcus medium (nutrient medium for bacterial growth). Their concentrations are expressed as number of colonies per 100 milliliters of sample.

Biochemical oxygen demand (BOD). --A measure of the quantity of dissolved oxygen, in milligrams per liter, necessary for the decomposition of oryanic matter by inicrourganisins, such as bacteria.

Dissolved.--Tinat material in a representative water sample which passes trirough a 0.45 inicrometer membrane filter. This is a convenient operational definition used by Federal agencies that collect water data. Determinations of "dissolved" constituents are made on subsamples of the filtrate.

Hardness.--A physical-chemical characteristic of water that is comlionly recognized by the increased quantity of soap required to produce lather. It is attributable to the presence of alkaline earths (principally calcium and inagnesium) and is expressed as equivalent calcium carbonate $\left(\mathrm{CaCO}_{3}\right)$.

Micrograms per gram $(\mu \mathrm{g} / \mathrm{g}) .--A$ unit expressing the concentration of a chemical element as the mass (micrograns) of the element per unit mass of sediment.

Micrograms per liter (UG/L, $\mu \mathrm{g} / \mathrm{L}) .-\mathrm{A}$ unit expressing the concentration of chemical constituents in solution as mass (micrograrns) of solute per unit volume (liter) of water. One thousand micrograms per liter is equivalent to 1 milligram per liter. $\mathrm{mg} / \mathrm{L}) \frac{\text { Milligrams }}{--\mathrm{A} \text { unit for expressing the }}$ concentration of chemical constituents in solution. Milligrams per liter represent the mass of solute per unit volume (liter) of water. Concentration of suspended sediment also is expressed in milligrarns per liter, and is based on the mass of sediment per liter of water-sediment mixture.

Specific conductance.--A measure of the ability of a water to conduct an electrical current. It is expres- 


\subsection{Water-Qual ity-Rel ated Terms--Cont inued}

sed in micromhos per centimeter at $25^{\circ}$ Celsius. Specific conductance is related to the type and concentration of ions in solution and can be used for approximating the dissolvedsolids concentration in the water. Commonly, the concentration of dissolved solids (in milligrams per liter) is about 65 percent of the specific conductance (in micromhos). This relation is not constant from stream to stream, and it may vary in the same source with changes in the composition of the water.

Suspended, total.--The total concentration of a given constituent in the part of a representative watersuspended sediment sample that is re- tained on a 0.45 micrometer inembrane filter. This terin is used only when the analytical procedure assures measurement of at least 95 percent of the constituent determined. A knowledge of the expected form of the constituent in the sample, as well as the analytical methodology used, is required to determine when the results should be reported as "suspended, total." Determinations of "suspended, total" constituents are made either by analyzing portions of the inaterial collected on the filter or, more cominonly, by difference, based on determinations of (1) dissolved and (2) total concentrations of the constituent. 


\subsection{Sediment-Related Terms}

Sediment.--Solid material that originates mostly from disintegrated rocks and is transported by, suspended in, or deposited from water; it includes chemical and biochemical precipitates and decomposed organic material, such as humus. The quantity, characteristics, and cause of the occurrence of sediment in streams are affected by environmental factors. Some major factors are degree of slope, length of slope, soil characteristics, land use, and quantity and intensity of precipitation.

Particle-size classification...American Geophysical Union Subcommittee on Sediment Terminology. The classification is as follows:

\section{Classification Size (millimeters)}

$\begin{array}{ll}\text { Clay } & 0.00024-0.004 \\ \text { Silt } & 0.004-0.062 \\ \text { Sand } & 0.062-2.0 \\ \text { Gravel } & 2.0-64.0\end{array}$

Suspended sedimant.--The sediment that at any given time is maintained in suspension by the upward components of turbulent currents or that exists in suspension as a colloid.

Suspended-sediment concentration.--The velocity-weighted concentration of suspended sediment in the sampled zone (from the water surface to a point about 0.3 foot above the bed) expressed as milligrams of dry sediment per liter of water-sediment mixture.

Suspended-sediment discharge (tons/day).--The rate at which dry weight of sediment passes a section of a stream, or is the quantity of sediment, as measured by dry weight or volume, that passes a section during a given time. It is computed by multiplying discharge (in cubic feet per second) times concentration (in milligrams per liter) times 0.0027 . Suspended-sediment load... The quantity of suspended sediment passing a section in a specified period. day). $\frac{\text { Total sediment discharge (tons/- }}{\text { - The sum of the suspended-sedi- }}$ ment discharge and the bed-load discharge. It is the total quantity of sediment, as measured by dry weight or volume that passes a section during a given time. 